UNIVERSIDADE DE SÃO PAULO

ESCOLA DE ENGENHARIA DE SÃO CARLOS

DEPARTAMENTO DE GEOTECNIA

ANA PAULA PEREIRA CARVALHO

Mapeamento geoambiental do município de Delfinópolis (MG) 



\section{Mapeamento geoambiental do município de Delfinópolis (MG)}

Dissertação apresentada à Escola de Engenharia de São Carlos da Universidade de São Paulo para obtenção do título de Mestre em Ciências.

Área de Concentração: Geotecnia

Orientador: Prof. Dr. Osni José Pejon

\section{VERSÃO CORRIGIDA}

Original se encontra disponível na Unidade que aloja o Programa

São Carlos - SP 
AUTORIZO A REPRODUÇÃO TOTAL OU PARCIAL DESTE TRABALHO, POR QUALQUER MEIO CONVENCIONAL OU ELETRO̊NICO, PARA FINS DE ESTUDO E PESQUISA, DESDE QUE CITADA A FONTE.

Carvalho, Ana Paula Pereira

Mapeamento geoambiental do municipio de Delfinópolis (MG) / Ana Paula Pereira Carvalho; orientador Prof. Dr. Osni José Pejon. Săo Carlos, 2017.

Dissertação (Mestrado) - Programa de Pós-Graduaçăo e Área de Concentração em Geotecnia -- Escola de Engenharia de São Carlos da Universidade de São Paulo, 2017.

1. Análise de Agrupamentos. 2. Morfometria. 3. Atributos do Meio Físico. 4. Parque Nacional da Serra da Canastra. 5. PNSC. I. Título. 


\section{FOLHA DE JULGAMENTO}

Candidata: Bacharela ANA PAULA PEREIRA CARVALHO.

Título da dissertaçāo: "Mapeamento geoambiental do município de Delfinópolis (MG)".

Data da defesa: 05/05/2017.

Comissāo Julgadora:

Prof. Titular Osni José Pejon

(Orientador)

(Escola de Engenharia de São Carios/EESC)

Prof. Dr. Luiz Nishiyama

(Universidade Federal de Uberlândia/UFU)

Profa. Dra. Denise Balestrero Menezes

(Universidade Federal de São Carios/UFSCar)
Resultado:
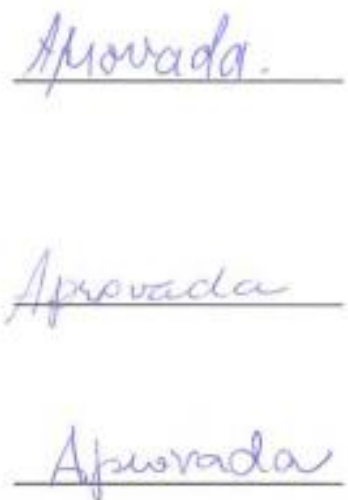

Coordenador do Programa de Pós-Graduação em Geotecnia:

Prof. Dr. Edmundo Rogério Esquivel

Presidente da Comissāo de Pós-Graduação:

Prof. Associado Luis Fernando Cosła Alberto 



\section{AGRADECIMENTOS}

A DEUS, meu Alicerce, pelo dom da vida, por sua grande misericórdia derramada a cada manhã, o meu louvor é para o Nosso Único DEUS.

Aos meus pais que amo sem medidas, Antonio e Rejane, pelo amor, cuidado, compreensão, pelas palavras de incentivo, por terem me ensinado os princípios e os valores da vida, agradeço a vocês por serem os melhores pais do mundo, vocês são os meus exemplos de vida.

As minhas irmãs, Ana Cláudia e Núbia, minhas companheiras que tornam meus dias cada vez mais felizes, agradeço a vocês por todos os nossos momentos, amo muito vocês.

Ao Prof. Dr. Osni, pela orientação, amizade, confiança, por todos os ensinamentos transmitidos, e pela contribuição com o meu crescimento profissional e pessoal.

Ao Prof. Dr. Eduardo Collares e a Prof ${ }^{a}$. Dr ${ }^{a}$ Ana Carina Collares, pela confiança e pelos ensinamentos, com vocês aprendi muitas coisas que carregarei para sempre, vocês fazem parte da minha história.

A Prof ${ }^{a}$. Dra . Valéria, pela amizade e confiança, pela oportunidade de estágio em docência no ensino superior.

Ao Prof. Dr. Lázaro pelos ensinamentos, pelos momentos de alegria e descontração.

Aos professores do Departamento de Geotecnia, pela atenção e conhecimentos transmitidos.

A equipe do Projeto Grande Minas, em especial a Naara, pela atenção e dedicação, sou grata por todos os produtos e conhecimentos disponibilizados para este trabalho, esta equipe é maravilhosa.

Aos amigos de mestrado da turma 2015: Ana Cláudia, Cahio, Denis, Gabriel, Jacqueline, Jailto, Monique, Sérgio, Yara e Zorany, agradeço por todos os momentos, pelos conhecimentos transmitidos, pela amizade e alegria, aprendi muito com cada um de vocês.

Aos amigos da sala de mapeamento (Ana Cláudia, Bia, Cláudinha, Lucas, Moisés e Monique) e a todos os amigos do departamento, pela alegria de todos os dias, pela amizade e ensinamentos. 
Aos técnicos e funcionários do Departamento de Geotecnia: Álvaro, Bene, Damiana, Décio, Dito, Herivelto, José Luís, Maristela, Neiva, Oscar, Sr. Antonio, Tiago e Toninho, pela amizade e disposição em ajudar.

Aos funcionários da Prefeitura de Delfinópolis, pela atenção e disponibilidade em ajudar.

Aos meus familiares e amigos, pela compreensão e torcida, amo muito vocês.

Ao CNPq pela concessão da bolsa de estudos.

Meus sinceros agradecimentos, Muito Obrigada!!! 
Ainda que eu tivesse o dom da profecia, o conhecimento de todos os mistérios e de toda a ciência; ainda que eu tivesse toda a fé, a ponto de transportar montanhas, se não tivesse o amor, eu não seria nada. 



\section{RESUMO}

CARVALHO, A. P. P. Mapeamento geoambiental do município de Delfinópolis (MG). Dissertação (Mestrado em Geotecnia) - Escola de Engenharia de São Carlos, Universidade de São Paulo, 2017.

O estudo do espaço físico territorial é de extrema importância para o planejamento municipal, principalmente quando se situa no seu limite administrativo uma área protegida. Neste contexto, o mapeamento geoambiental se destaca como uma ferramenta essencial na identificação e delimitação de regiões que apresentam características semelhantes, direcionando de forma rápida e eficiente os órgãos gestores na solução das demandas de cada área. Este trabalho teve como objetivo realizar o mapeamento geoambiental do município de Delfinópolis (MG), na escala de 1:50.000, tendo como base a utilização da análise de agrupamentos para delimitar as áreas com alto nível de similaridade referente às características do meio físico. O município pode ser considerado especial, devido 40,35\% da sua área corresponder à unidade de conservação do Parque Nacional da Serra da Canastra (PNSC). O mapeamento teve por base a caracterização física das bacias hidrográficas de até $4^{\mathrm{a}}$ ordem de ramificação que se encontram totalmente inseridas no município. A análise de agrupamentos das bacias de $1^{\mathrm{a}}$ ordem foi realizada considerando o percentual de área de três atributos fundamentais do meio físico (materiais inconsolidados, substrato rochoso, e declividade). Já as bacias hidrográficas de $2^{\mathrm{a}}, 3^{\mathrm{a}}$ e $4^{\mathrm{a}}$ ordens foram inicialmente agrupadas com base em nove índices morfométricos e posteriormente analisadas frente aos mesmos atributos fundamentais do meio físico. Em todas as análises de agrupamentos foi utilizado o método pareado igualmente ponderado e na análise dos dendrogramas foi estabelecida uma linha de fusão de $20 \%$ para identificação das unidades homogêneas e de $80 \%$ para os grupos de unidades que apresentam alto nível de dissimilaridade. A integração da análise morfométrica com as informações do meio físico permitiu a delimitação de nove unidades geoambientais com nível de homogeneidade compatível com a escala de mapeamento. A análise dessas unidades mostrou certa compatibilidade das características físicas da zona intangível e da zona de ocupação temporária do PNSC com a unidade UG 8. Com relação às áreas de preservação permanente, nenhuma das unidades obedece totalmente os limites previstos na legislação. Dentre as unidades, duas apresentam-se pouco degradadas, duas encontram-se degradadas e as demais se enquadram em nível regular de degradação.

Palavras-chave: Análise de Agrupamentos. Morfometria. Atributos do Meio Físico. Parque Nacional da Serra da Canastra. PNSC. 



\begin{abstract}
CARVALHO, A. P. P. Geoenvironmental mapping of the municipality of Delfinópolis (MG). Dissertação (Mestrado em Geotecnia) - Escola de Engenharia de São Carlos, Universidade de São Paulo, 2017.
\end{abstract}

The study of territorial physical space is extremely important for municipal planning, especially when a protected area is located within its administrative boundary. In this context, the geoenvironmental mapping stands out as an essential tool in the identification and delimitation of regions that present similar characteristics, directing public management quickly and efficiently in the solution of the demands of each area. The objective of this work is to perform the geoenvironmental mapping of the city of Delfinópolis (MG), in the scale of 1: 50.000, based on the use of cluster analysis to delimit the areas with high level of similarity referent to the characteristics of the physical environment. The municipality can be considered special, since $40,35 \%$ of its area corresponds to the conservation unit of National Park Serra da Canastra (PNSC).The mapping was based on the physical characteristics of the watersheds up to the $4^{\text {th }}$ order of ramification that are totally inserted in the municipality. The analysis of groupings of the $1^{\text {st }}$ order basins was performed considering the percentage of area of three fundamental attributes of the physical environment (unconsolidated materials, geology, and slope). The $2^{\text {nd }}, 3^{\text {rd }}$ and $4^{\text {th }}$ order watersheds were initially grouped based on nine morphometric indices and later analyzed against the same fundamental attributes of the physical environment. In all cluster analysis, we used the unweighted pairgroup method and in the analysis of dendrograms a $20 \%$ melting line was established to identify the homogeneous units and $80 \%$ of the groups of units with a high level of dissimilarity.The integration of the morphometric analysis with the information about the physical environment allowed the delimitation of nine geoenvironmental units with level of homogeneity compatible with the scale of mapping. The analysis of these units showed the similarity of the physical characteristics of the intangible zone and the temporary occupation zone of the PNSC with the unit UG 8.In relation to the areas of permanent preservation, none of the units fully obey the limits established in the legislation. Among the units, two are poorly degraded, two are degraded and the other ones fall into a regular level of degradation.

Keywords: Clusters Analysis. Morphometry. Attributes of the Physical Environment. National Park Serra da Canastra. PNSC. 



\section{LISTA DE FIGURAS}

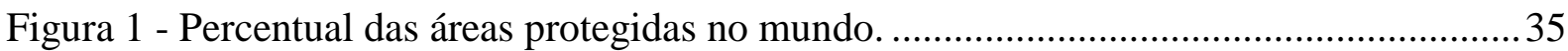

Figura 2 - Tipos de unidades de conservação com suas respectivas categorias........................36

Figura 3 - Estrutura de avaliação da gestão de uma área protegida. ........................................45

Figura 4 - Etapas de um plano de manejo de uma unidade de conservação..............................46

Figura 5 - Parâmetros físicos e o gerenciamento de bacias hidrográficas................................51

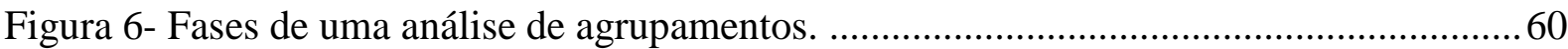

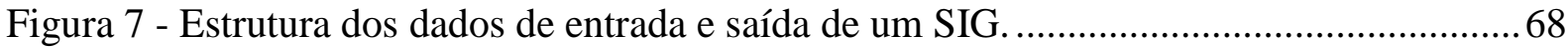

Figura 8 - Componentes básicos do sistema de aquisição de informações por SR ................. 72

Figura 9 - Etapas para a elaboração do mapa de zoneamento geoambiental. .......................... 77

Figura 10 - Níveis da elaboração do mapeamento geoambiental. ........................................... 85

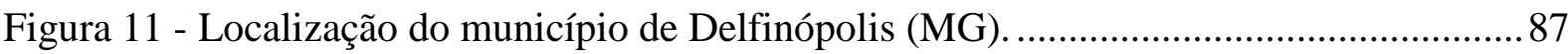

Figura 12 - Principais vias de acesso à área de estudo na região sudeste. .............................. 88

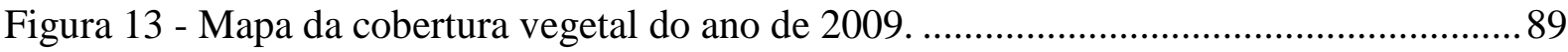

Figura 14 - Mapa dos cursos d'água principais do município de Delfinópolis (MG).............91

Figura 15 - Mapa de geologia da área de estudo elaborado pelo CPRM. ...............................93

Figura 16 - Mapa de geomorfologia da área de estudo elaborado pela CETEC. ....................93

Figura 17 - Fluxograma das etapas desenvolvidas neste trabalho........................................99

Figura 18 - Espacialização dos pontos de referência e as datas das respectivas imagens...... 101

Figura 19 - Mosaico das imagens de satélite que contemplam o município de Delfinópolis (MG) 102

Figura 20 - Planos de informação utilizados para a elaboração do MDEHC......................... 103

Figura 21 - Etapas para a definição das unidades geoambientais da área de estudo.............. 105

Figura 22 - Etapas de agrupamentos das bacias hidrográficas da área de estudo. ................. 109

Figura 23 - Mapa de materiais inconsolidados da área de estudo. ........................................ 122

Figura 24 - Mapa de substrato rochoso da área de estudo...................................................... 123

Figura 25 - Carta de declividades da área de estudo. .......................................................... 125

Figura 26 - Dendrograma das bacias hidrográficas de $1^{\mathrm{a}}$ ordem quanto aos atributos do meio físico.

Figura 27 - Dendrograma da análise de agrupamentos das bacias hidrográficas de $2^{\mathrm{a}}$ ordem, com relação aos índices morfométricos. 
Figura 28 - Dendrograma da análise de agrupamentos das bacias hidrográficas de $2^{\mathrm{a}}$ ordem, com relação aos atributos do meio físico.

Figura 29 - Dendrograma da análise de agrupamentos das bacias hidrográficas de $3^{\text {a }}$ ordem, com relação aos índices morfométricos.

Figura 30 - Dendrograma da análise de agrupamentos das bacias hidrográficas de $3^{\mathrm{a}}$ ordem, com relação aos atributos do meio físico.

Figura 31 - Dendrograma da análise de agrupamentos das bacias hidrográficas de $4^{\mathrm{a}}$ ordem, com relação aos índices morfométricos.

Figura 32 - Dendrograma da análise de agrupamentos das bacias hidrográficas de $4^{\mathrm{a}}$ ordem, com relação aos atributos do meio físico.

Figura 33 - Bacias hidrográficas da área de estudo antes das análises de agrupamentos.

Figura 34 - Dendrograma após as análises de agrupamentos para a delimitação das unidades geoambientais. 138

Figura 35 - Mapa de landforms.

Figura 36 - Dendrograma após a análise de agrupamentos das onze unidades geoambientais com relação às classes de landforms.

Figura 37 - Unidades geoambientais da área de estudo.

Figura 38 - Mapa das unidades geoambientais do município de Delfinópolis e as zonas de manejo do PNSC.

Figura 39 - Percentual de área das APPs em cada unidade geoambiental ocupada por vegetação natural.

Figura 40 - Mapa de área de proteção no município de Delfinópolis de acordo com a legislação ambiental.

Figura 41 - Uso e ocupação do solo no município de Delfinópolis.

Figura 42 - Percentual das classes de uso e ocupação do solo das unidades geoambientais. 177

Figura 43 - Intervalos de valores quanto ao nível de degradação.

Figura 44 - Mapa de classificação das unidades geoambientais quanto ao nível de degradação. 


\section{LISTA DE TABELAS}

Tabela 1 - Áreas protegidas no mundo.

Tabela 2 - Objetivos das unidades de conservação, conforme o artigo $4^{\circ}$ da Lei Federal de $9.985 / 2000$.

Tabela 3 - Objetivos e uso dos tipos de unidades de conservação.

Tabela 4 - Principais funções das categorias de manejo das áreas protegidas recomendadas pela International Union for Conservation of Nature (IUCN, 2003).

Tabela 5 - Número e área $\left(\mathrm{km}^{2}\right)$ das unidades de conservação de proteção integral.

Tabela 6 - Número e área $\left(\mathrm{km}^{2}\right)$ das unidades de conservação de uso sustentável. 40

Tabela 7 - Possíveis zonas existentes nos diferentes tipos de UCs. 42

Tabela 8 - Informações sobre alguns planos de manejos de unidades de conservação nacionais e internacionais.

Tabela 9 - Variáveis morfométricas de acordo com os tipos de análise..................................53

Tabela 10 - Estudos realizados com o uso de índices morfométricos. ....................................58

Tabela 11 - Informações sobre alguns índices relacionados à degradação ambiental..............63

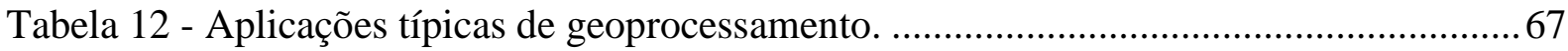

Tabela 13 - Vantagens e desvantagens dos formatos dos dados de entrada em um SIG. ........68

Tabela 14 - Considerações gerais sobre as energias eletromagnéticas, segundo Steffen, Moraes e Gama (1996).

Tabela 15 - Tipos de resoluções importantes de uma imagem de satélite, segundo Câmara e Monteiro (2004) .72

Tabela 16 - Atributos utilizados para o zoneamento geoambiental. ...................................... 79

Tabela 17 - Níveis dos objetos de mapeamento geoambiental............................................... 86

Tabela 18 - Área dos tipos de cobertura vegetal do município de Delfinópolis, no ano de 2009. .90

Tabela 19 - Classificação das unidades geológicas da área de estudo. 92

Tabela 20 - Área das classes do mapa de landforms no município de Delfinópolis. 94

Tabela 21 - Classes dos atributos do meio físico adotados nas análises das bacias hidrográficas de $1^{\mathrm{a}}$ ordem.

Tabela 22 - Índices morfométricos calculados para as bacias hidrográficas de $2^{\mathrm{a}}, 3^{\mathrm{a}}$ e $4^{\mathrm{a}}$ ordem. 108

Tabela 23 - Linha de fusão adotada para cada etapa da análise de agrupamentos. 110

Tabela 24 - Critérios adotados para a elaboração do Mapa de Legislação Ambiental. 
Tabela 25 - Etapas para a obtenção das APPs dos topos de morros, conforme Santos (2013).

Tabela 26 - Subclasses e classes do mapa de uso e ocupação do solo.

Tabela 27 - Pesos para os respectivos tipos de uso e ocupação do solo no município.

Tabela 28 - Classes do Índice de Transformação Antrópica definidas por Cruz et al. (1998).

Tabela 29 - Tipos de análises realizadas para as unidades geoambientais e os produtos utilizados para cada uma delas.

Tabela 30 - Número de bacias antes e depois das análises de agrupamentos.

Tabela 31 - Percentual de área dos atributos do meio físico analisados na UG 1 .

Tabela 32 - Percentual de área dos produtos interpretativos do meio físico analisados na UG 1.

Tabela 33 - Percentual de área dos atributos do meio físico analisados na UG 2. 1466

Tabela 34 - Percentual de área dos produtos interpretativos do meio físico analisados na UG 2.

Tabela 35 - Percentual de área dos atributos do meio físico analisados na UG 3. 1488

Tabela 36 - Percentual de área dos produtos interpretativos do meio físico analisados na UG 3.

Tabela 37 - Percentual de área dos atributos do meio físico analisados na UG 4.

Tabela 38 - Percentual de área dos produtos interpretativos do meio físico analisados na UG4.

Tabela 39 - Percentual de área dos atributos do meio físico analisados na UG 5.

Tabela 40 - Percentual de área dos produtos interpretativos do meio físico analisados na UG5.

Tabela 41 - Percentual de área dos atributos do meio físico analisados na UG 6.

Tabela 42 - Percentual de área dos produtos interpretativos do meio físico analisados na UG 6.

Tabela 43 - Percentual de área dos atributos do meio físico analisados na UG 7.

Tabela 44 - Percentual de área dos produtos interpretativos do meio físico analisados na UG 7.

Tabela 45 - Percentual de área dos atributos do meio físico analisados na UG 8. 1566

Tabela 46 - Percentual de área dos produtos interpretativos do meio físico analisados na UG 8.

Tabela 47 - Percentual de área dos atributos do meio físico analisados na UG 9. 
Tabela 48 - Percentual de área dos produtos interpretativos do meio físico analisados na UG 9.

Tabela 49 - Área $\left(\mathrm{km}^{2}\right.$ e \%) das zonas de manejo do PNSC situadas nas unidades geoambientais.

Tabela 50 - Área $\left(\mathrm{km}^{2} \mathrm{e} \%\right)$ das unidades geoambientais situadas nas zonas de manejo do PNSC. 16161

Tabela 51 - Áreas de preservação permanente que deveriam existir nas unidades geoambientais conforme a legislação. 1666

Tabela 52 - Porcentagens de Mata, Campo e Capoeira presentes nas áreas de preservação permanente em cada unidade geoambiental.

Tabela 53 - Déficit de cobertura vegetal (\%) das áreas de preservação permanente nas unidades geoambientais. 17070

Tabela 54 - Total $\left(\mathrm{km}^{2}\right.$ e \%) das áreas de proteção que deveriam existir no município de Delfinópolis. 17070

Tabela 55 - Pesos das classes do uso e ocupação do solo da área de estudo. 1788

Tabela 56 - Percentual de área das classes de uso e ocupação do solo nas unidades geoambientais. 1788

Tabela 57 - Valores do ITA e o enquadramento das unidades geoambientais quanto às pressões antrópicas. 1799 



\section{LISTA DE EQUAÇÕES}

Equação 1 - Índice de Forma .................................................................................. 54

Equação 2 - Índice de Circularidade ............................................................................ 54

Equação 3 - Densidade de Drenagem .......................................................................... 55

Equação 4 - Densidade Hidrográfica …………………………………………….... 55

Equação 5 - Textura Topográfica ……………………………………………….... 56

Equação 6 - Coeficiente de Manutenção .................................................................... 56

Equação 7 - Relação de Relevo ………………………………………………….... 57

Equação 8 - Índice de Rugosidade ………………………………………………... 57

Equação 9 - Extensão do Percurso Superficial ........................................................... 58

Equação 10 - Índice de Transformação Antrópica........................................................ 118 



\section{LISTA DE SIGLAS}

AA Análise de Agrupamentos

APP Área de Preservação Permanente

BH Bacia Hidrográfica

CETEC Centro Tecnológico de Minas Gerais

CNUC Cadastro Nacional de Unidade de Conservação

Cm Coeficiente de Manutenção

CPRM Serviço Geológico do Brasil

Dd Densidade de Drenagem

DER Departamento de Estradas de Rodagens

Dh Densidade Hidrográfica

EC Estatuto da Cidade

FBCN Fundação Brasileira para a Conservação da Natureza

FIRJAN Federação das Indústrias do Estado do Rio de Janeiro

FUNAI Fundação Nacional do Índio

IBAMA Instituto Brasileiro do Meio Ambiente e dos Recursos Naturais Renováveis

IBDF Instituto Brasileiro de Desenvolvimento Florestal

IBGE Instituto Brasileiro de Geografia e Estatística

Ic Índice de Circularidade

ITA Índice de Transformação Antrópica

IUGS International Union of Geological Sciences

IUCN International Union for Conservation of Nature

Ir Índice de Rugosidade

K Índice de Forma

MC Ministério das Cidades

MDEHC Modelo Digital de Elevação Hidrologicamente Consistente

PARNASO Parque Nacional da Serra dos Órgãos

PD Plano Diretor

PM Plano de Manejo

PNMA Política Nacional do Meio Ambiente

PNSC Parque Nacional da Serra da Canastra

PRAD Plano de Recuperação de Áreas Degradadas 


$\begin{array}{ll}\text { Rr } & \text { Relação de Relevo } \\ \text { SIG } & \text { Sistema de Informações Geográficas } \\ \text { SNUC } & \text { Sistema Nacional de Unidades de Conservação da Natureza } \\ \text { SR } & \text { Sensoriamento Remoto } \\ \text { Tt } & \text { Textura Topográfica } \\ \text { UGs } & \text { Unidades Geoambientais } \\ \text { UC } & \text { Unidade de Conservação } \\ \text { ZA } & \text { Zoneamento Ambiental } \\ \text { ZAm } & \text { Zona de Amortecimento } \\ \text { ZG } & \text { Zoneamento Geoambiental } \\ \text { ZI } & \text { Zona Intangível } \\ \text { ZOT } & \text { Zona de Ocupação Temporária }\end{array}$




\section{SUMÁRIO}

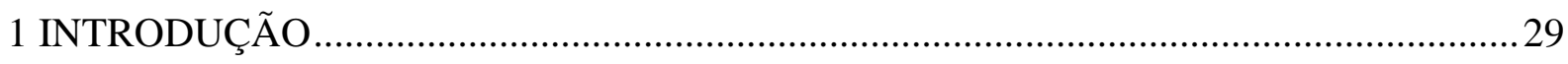

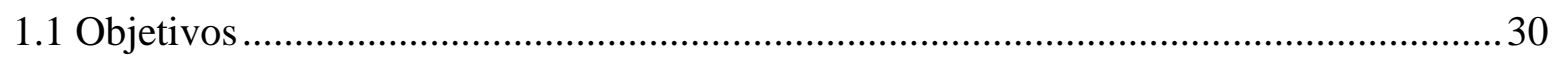

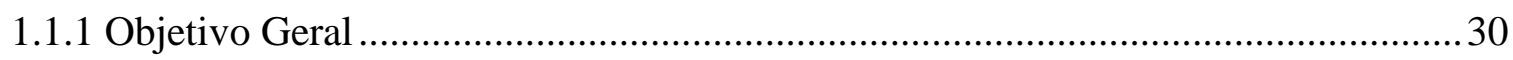

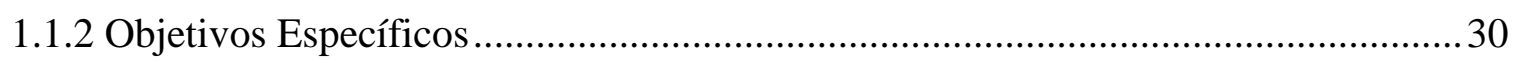

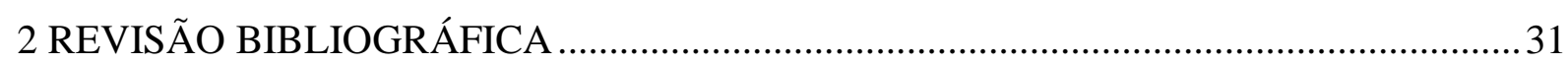

2.1 Legislação ambiental aplicada no planejamento municipal........................................ 31

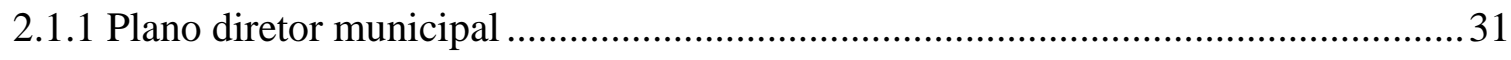

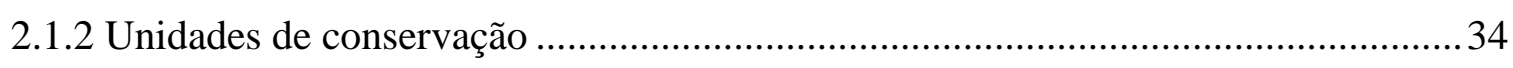

2.1.2.1 Zonas de manejo de parques nacionais..................................................... 40

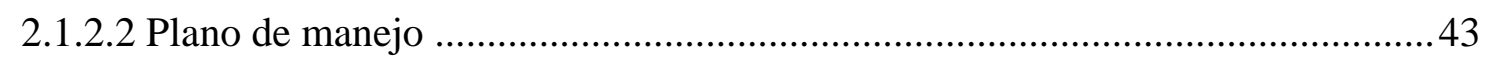

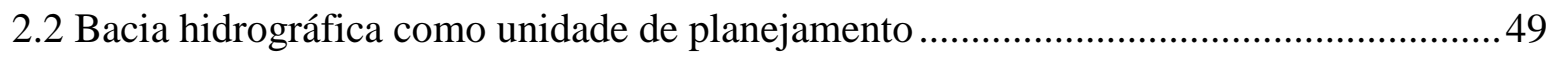

2.2.1 Caracterização morfométrica de bacias hidrográficas ..........................................52

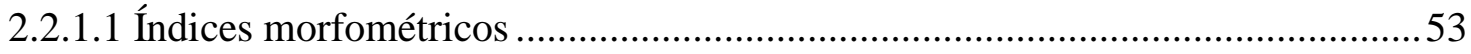

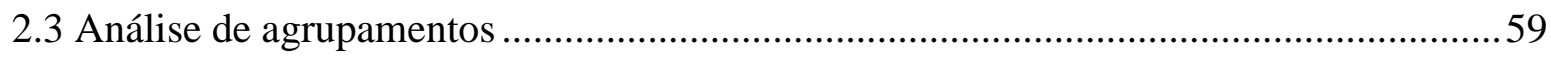

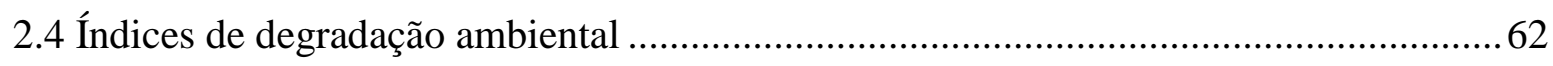

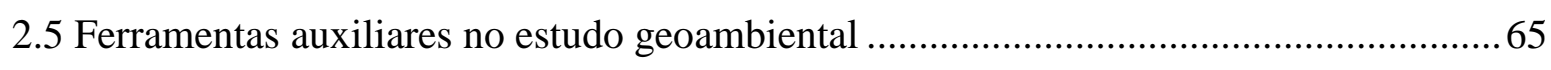

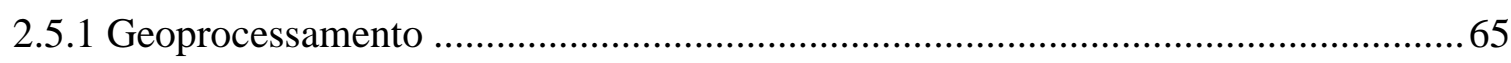

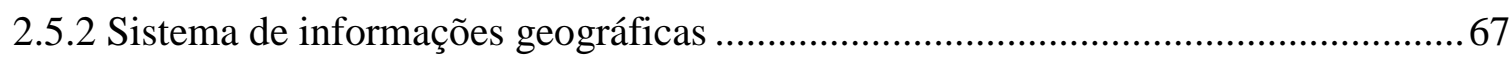

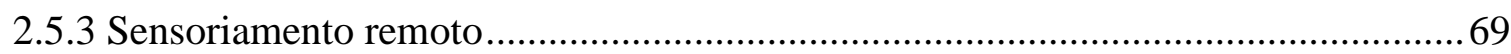

2.5.3.1 Produtos utilizados para aquisição de informações remotas ............................ 72

2.6 Zoneamento ambiental e geoambiental ................................................................ 74

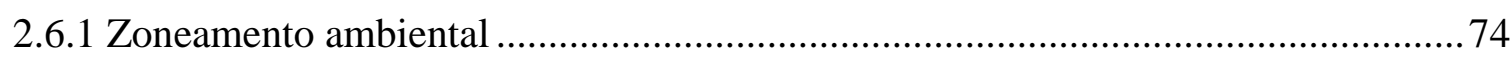

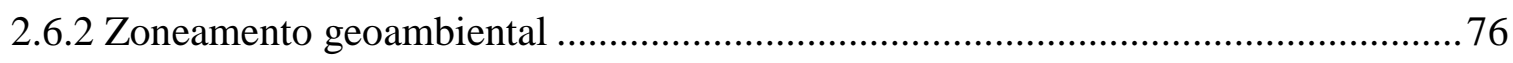

2.7 Mapeamento geológico-geotécnico e geoambiental ................................................... 80

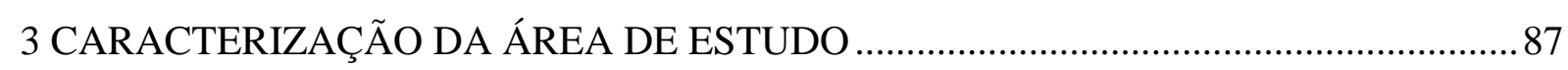

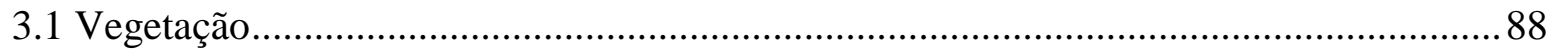

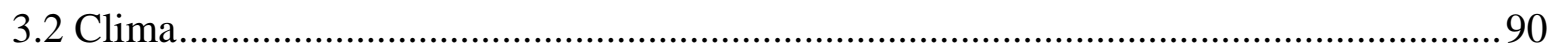

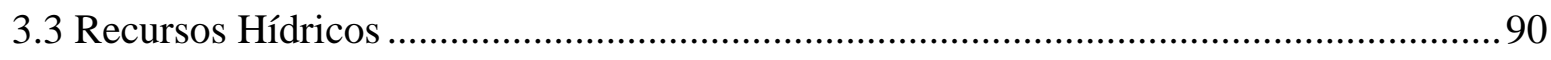

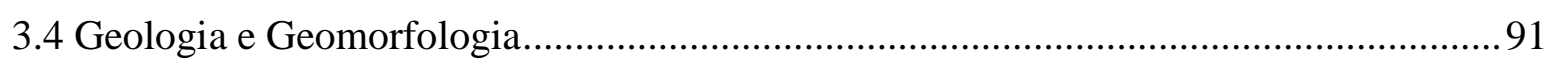

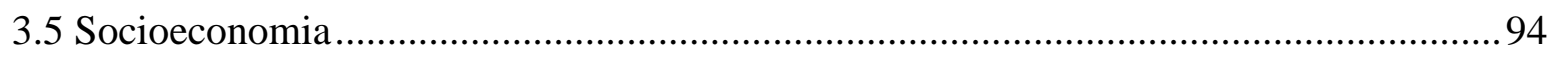

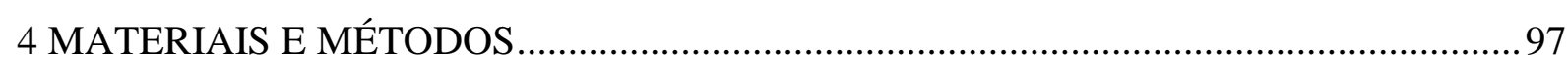

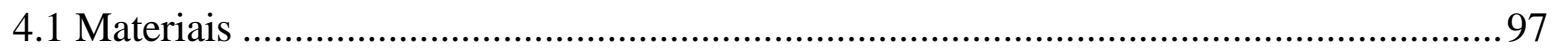


4.2.1 Tratamento dos dados da área de estudo em um sistema georreferenciado.

4.2.1.1 Preparação dos planos de informação para a área de estudo

4.2.1.2 Obtenção de imagens de satélite e georreferenciamento

4.2.2 Elaboração do Modelo Digital de Elevação Hidrologicamente Consistente (MDEHC) e da Carta de Declividades 103

4.2.3 Procedimentos para o estabelecimento das unidades geoambientais na área de estudo 104

4.2.3.1 Caracterização física das bacias hidrográficas de $1^{\mathrm{a}}$ ordem 106

4.2.3.2 Caracterização morfométrica das bacias hidrográficas de $2^{\mathrm{a}}, 3^{\mathrm{a}}$ e $4^{\mathrm{a}}$ ordem $\ldots 107$

4.2.3.3 Análise de agrupamentos das bacias hidrográficas ..................................... 108

4.2.3.4 Estabelecimento das unidades geoambientais ............................................ 110

4.2.4 Análise do meio físico das unidades geoambientais 111

4.2.5 Análise das unidades geoambientais com relação às zonas de manejo da unidade de conservação 112

4.2.6 Mapeamento das áreas ambientais com restrições legais 112

4.2.6.1 Áreas de preservação permanente dos cursos d'água. 114

4.2.6.2 Áreas de Preservação Permanente dos topos de morros 114

4.2.6.3 Análise das áreas ambientais com restrição legal nas unidades geoambientais 115

4.2.7 Análise das Unidades Geoambientais em relação ao uso e ocupação do solo 116

4.2.7.1 Edição do uso e ocupação do solo 116

4.2.7.2 Obtenção do Índice de Transformação Antrópica (ITA) 117

4.2.7.3 Análise do uso e ocupação do solo nas unidades geoambientais 119

4.2.8 Estabelecimento de recomendações para as unidades geoambientais 119 5 RESULTADOS E DISCUSSÃO

5.1 Análise de agrupamentos para o estabelecimento das unidades geoambientais 121

5.1.1 Análise de agrupamentos das bacias hidrográficas de $1^{\mathrm{a}}$ ordem 121

5.1.2 Análise de agrupamentos das bacias hidrográficas de $2^{\mathrm{a}}, 3^{\mathrm{a}}$ e $4^{\mathrm{a}}$ ordem . 128

5.1.3 Delimitação das Unidades Geoambientais

5.2 Unidades geoambientais frente aos documentos temáticos e interpretativos

5.3 Confrontação das unidades geoambientais com as zonas de manejo do PNSC

5.3.1 Considerações sobre as zonas de manejo e o mapeamento geoambiental do município 
5.4 Unidades geoambientais e áreas ambientais com restrição legal.................................166

5.5 Unidades geoambientais e uso e ocupação do solo .................................................... 173

5.5.1 Índice de Transformação Antrópica nas unidades geoambientais ......................... 177

5.6 Síntese das características das unidades geoambientais e recomendações ................... 183

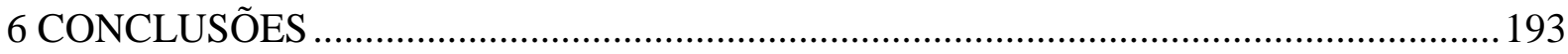

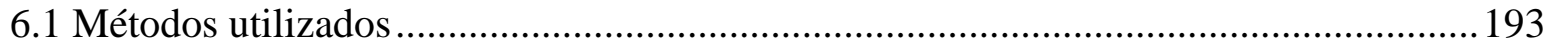

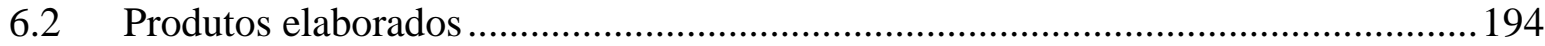

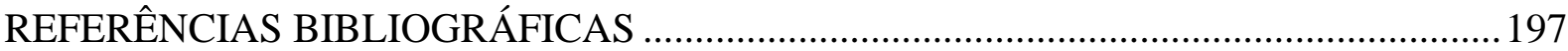

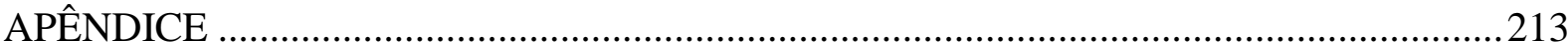

APÊNDICE A - Percentual de área dos atributos do meio físico das bacias hidrográficas de $1^{\mathrm{a}}$ ordem antes da $1^{\mathrm{a}}$ análise de agrupamentos

APÊNDICE B - Percentual de área dos atributos do meio físico das bacias hidrográficas de $1^{\mathrm{a}}$ ordem para a última análise de agrupamentos

APÊNDICE C - Índices morfométricos das bacias hidrográficas de $2^{\mathrm{a}}$ ordem 237

APÊNDICE D - Percentual de área dos atributos do meio físico das bacias hidrográficas de $2^{\mathrm{a}}$ ordem

APÊNDICE E - Índices morfométricos das bacias hidrográficas de $3^{\mathrm{a}}$ ordem 247

APÊNDICE F - Percentual de área dos atributos do meio físico das bacias hidrográficas de $3^{\mathrm{a}}$ ordem 249

APÊNDICE G - Índices morfométricos das bacias hidrográficas de $4^{\mathrm{a}}$ ordem 253

APÊNDICE H - Percentual de área dos atributos do meio físico das bacias hidrográficas de $4^{\mathrm{a}}$ ordem 255 



\section{INTRODUÇão}

O estudo do espaço físico territorial é fundamental para o planejamento municipal, principalmente quando se situa no seu limite administrativo uma área protegida. Em muitos municípios brasileiros, o planejamento não é considerado uma das etapas iniciais para futuras tomadas de decisão, ou quando considerado não é realizado de forma condizente, levando a ocorrência de diversos problemas que consequentemente afetam direta ou indiretamente o equilíbrio dinâmico da área, em curto, médio ou longo prazo.

Neste contexto, o mapeamento geoambiental é considerado de extrema importância para o planejamento, por se tratar de uma ferramenta que identifica e delimita regiões que apresentam características semelhantes, direcionando de forma rápida e eficiente os gestores públicos na solução das demandas da área. Segundo Silva e Dantas (2010), através da integração de dados do relevo, substrato rochoso, recursos hídricos, solos e uso e ocupação, o estudo geoambiental oferece informações sobre os ambientes geológicos em que se originaram os terrenos, além de considerar as suas potencialidades e restrições.

O mapeamento geoambiental realizado neste trabalho apresenta uma sistemática de análise diferenciada em que emprega o método de análise de agrupamentos (Cluster Analysis) para a junção de áreas que apresentam mínima heterogeneidade quanto aos aspectos do meio físico. Esta análise multivariada foi realizada com base em nove índices morfométricos e no percentual de área de três atributos (aspecto textural dos solos; substrato rochoso; e declividade). Parte-se do pressuposto que esta análise conduz a identificação de unidades que, por apresentarem aspectos morfométricos semelhantes, poderiam servir de base para o estabelecimento de unidades geoambientais.

A área de estudo compreende o município de Delfinópolis, localizado no sudoeste do Estado de Minas Gerais, considerada como uma área especial, por apresentar um pouco mais de $40 \%$ de seu espaço físico composto pela unidade de conservação do Parque Nacional da Serra da Canastra (PNSC).

Além de mapear e caracterizar as unidades geoambientais do município quanto as suas características físicas, foram realizadas também análises integradas destas unidades envolvendo critérios de legislação como: as áreas de preservação permanente e as zonas de manejo do PNSC. Além disso, foi verificada a carga antrópica dentro de cada unidade 
geoambiental tendo como base a aplicação do Índice de Transformação Antrópica (ITA). Os resultados deste trabalho poderão auxiliar no ordenamento territorial da área de estudo, bem como na atualização do zoneamento do PNSC, além de contribuir na elaboração dos planos de ações dos órgãos gestores, para que o desenvolvimento do município aconteça de forma satisfatória e sustentável.

\subsection{Objetivos}

\subsubsection{Objetivo Geral}

Este trabalho teve como objetivo geral realizar o mapeamento geoambiental do município de Delfinópolis (MG), na escala de 1:50.000, tendo como base a utilização da análise de agrupamentos para delimitar as áreas com alto nível de similaridade referente às características do meio físico. Busca-se também que este trabalho venha a contribuir com o planejamento municipal, visto que $40,35 \%$ da área de estudo correspondem à unidade de conservação do Parque Nacional da Serra da Canastra.

\subsubsection{Objetivos Específicos}

Como objetivos específicos citam-se:

- Realizar análises integradas com as unidades geoambientais considerando os atributos do meio físico, as zonas de manejo do Parque Nacional da Serra da Canastra, as áreas ambientais com restrição legal, de modo a contribuir com o ordenamento físicoterritorial;

- Verificar a pressão antrópica existente em cada unidade geoambiental do município, com base na análise do uso e ocupação do solo;

- Propor recomendações para as unidades geoambientais frente às análises realizadas neste trabalho, de forma a contribuir com a preservação, conservação e desenvolvimento do município. 


\section{REVISÃo BIBLIOGRÁFICA}

\subsection{Legislação ambiental aplicada no planejamento municipal}

Uma nova fase relacionada à questão ambiental foi criada no país após a efetivação da Política Nacional do Meio Ambiente (PNMA) (Lei Federal nº 6.938/1981). Essa lei apresenta vários critérios a serem adotados, dentre eles diversos instrumentos, como exemplo, o zoneamento e controle do risco ambiental e a avaliação de impactos ambientais (PESTANA, 2006).

Para Peres e Silva (2013), mesmo com o crescimento da preocupação com a questão ambiental, este assunto encontra-se em um processo de contínua formação. Os autores relatam que ainda há dificuldade de integração entre políticas, além da ausência de interação entre as leis e os instrumentos urbanos e ambientais, sejam eles, municipais, estaduais ou federais. Estes casos, muitas vezes acabam atrapalhando a gestão por não obedecerem às legislações vigentes e sim a outros interesses.

Conforme Ávila e Malheiros (2012), dos mais de cinco mil municípios brasileiros, a minoria buscou caminhos voltados à gestão ambiental. Para a efetivação dos sistemas ambientais os municípios dependem do fortalecimento das instâncias de planejamento, para que obtenham segurança nas tomadas de decisão das políticas voltadas às boas práticas ambientais. $\mathrm{O}$ atraso das decisões sobre a questão ambiental de uma determinada área resulta em soluções que demandam maiores investimentos e dificuldades, comprometendo assim, o desenvolvimento dos seus setores, como exemplo, o econômico.

Nos próximos itens serão apresentados alguns instrumentos de ordenamento físicoterritorial dos municípios brasileiros.

\subsubsection{Plano diretor municipal}

No período de consolidação da Constituição Federal de 1988, um movimento de abrangência nacional uniu esforços para a inclusão de instrumentos no texto constitucional, que estabelecesse a função social da cidade no seu processo de construção. No entanto, foi 
incluído na Constituição Federal um capítulo específico para a política urbana, que apresenta alguns instrumentos para a garantia dos direitos dos municípios (BRASIL, 2001).

Mesmo com a elaboração do capítulo, foi necessária a criação de uma lei específica na esfera nacional. Durante um período de mais de dez anos houve várias negociações em busca da abertura de um espaço na Constituição para as questões da política urbana. A partir disso, foi criado o Projeto de Lei $n^{\circ} 5.788 / 1990$, porém este documento tornou-se vigente somente no ano de 2001 com a instituição do Estatuto da Cidade (n 10.257/2001) (BRASIL, 2001).

Após a efetivação da Lei Federal n 10.257/2001, que regulamenta os artigos 182 e 183 da Constituição Federal, o seu artigo $4^{\circ}$ estabelece os instrumentos indispensáveis para o planejamento municipal, em especial cita-se primeiramente o Plano Diretor (PD).

O PD é visto como uma lei municipal, o qual depende da participação da sociedade para sua elaboração. Este instrumento tem por objetivo organizar tanto o crescimento como também o desenvolvimento do município, além de elaborar cenários para o espaço físicoterritorial, podendo auxiliar também na definição da política ambiental a ser executada (OLIVEIRA et al., 2007).

Rezende e Ultramari (2007), também seguem o mesmo conceito, de que o PD é um instrumento de grande importância para as prefeituras quanto à gestão e ao planejamento dos municípios, visto que os princípios que o envolvem estão estabelecidos no Estatuto da Cidade (EC).

Segundo Meurer e Vieira (2010), o PD é um conjunto de diretrizes e propostas, que tem como função assegurar o desenvolvimento tanto na esfera social como econômica, além da organização físico-espacial dos diversos usos e das redes de infraestrutura, levando em consideração o período de curto, médio e longo prazo, visto que sua elaboração e implementação é de total responsabilidade do município.

Segundo Bernardy (2013) o planejamento municipal através do PD pode ser caracterizado em três esferas: técnica, legal e política. Sendo que a primeira contempla às informações do local que são utilizadas para o estudo do território. A segunda se baseia em analisar os fatores condicionantes e as restrições legais. E a terceira engloba a participação da comunidade, envolvendo os gestores públicos e os órgãos representativos, tanto para elaborar quanto para fiscalizar a aplicação do PD. Para o autor, dentre as esferas, as dimensões técnica e política se destacam como os pilares principais do planejamento e da gestão do município. 
Para Ultramari e Rezende (2008) os PDs quando elaborados atendem a três condições, sendo elas: formalidade processual de abranger a população na etapa de elaboração, implantação e fiscalização; consideração de toda a área do município nas análises (envolvendo também a área rural); e aspectos multidisciplinares do município, que relacionam com as condições sociais, econômicas e ambientais.

Segundo a Lei Federal n 10.257/2001, os municípios que apresentam mais que 20 mil habitantes são obrigados elaborar e implementar este instrumento. Desta forma consideram também os municípios integrantes de áreas metropolitanas e aglomerações urbanas; com áreas especiais de interesse em atividades turísticas; ou mesmo situados em áreas de atividades que apresentam impactos ambientais de grande magnitude na região ou no país (BRASIL, 2001). Além destes, foram incluídas pela Lei Federal nº 12.608/2012 os municípios que apresentam áreas susceptíveis à ocorrência de deslizamentos de grande impacto, inundações severas ou processos geológicos ou hidrológicos correlatos.

A obrigatoriedade do PD e a criação do Ministério das Cidades (MC) serviram como motivo para realizar um cenário de mobilização dos PD municipais. Em 2004, o MC identificou que dentre os municípios brasileiros, 1.682 eram obrigados elaborar ou revisar seu PD (GOMES MACHADO, 2014). As questões físico-territoriais, econômicas, financeiras, políticas, sociais, ambientais e de gestão vêm sendo um desafio para os municípios brasileiros, com isso se faz necessário avançar com as técnicas de planejamento elaboradas pela própria gestão local (REZENDE; ULTRAMARI, 2007).

Segundo Peres e Silva (2013), após a instituição do EC, o conceito ambiental tornouse um dos elementos essenciais para o planejamento urbano. Para os autores o EC definiu o PD do município em um novo instrumento estratégico, onde outros instrumentos da política urbana deveriam manter relação. Para Braga (2001), dentre os instrumentos de gestão ambiental, o PD destaca-se como um dos principais, devido a não existir uma tradição de política ambiental em esfera municipal no Brasil.

Conforme Costa, Campante e Araújo (2011), por apresentar menor atenção ao tratamento das diretrizes de meio ambiente, a maioria dos PD não envolvem também as características específicas da região, ou quando as contemplam são apresentadas de uma forma genérica, com apenas a citação de elementos que integram o patrimônio natural, que devem ser preservados. Segundo este pressuposto, o zoneamento ambiental apresentado nos planos diretores evidencia uma melhor aproximação com a realidade da área. Porém, caso não 
ocorra o estabelecimento dos critérios de uso e ocupação em conformidade com as zonas de interesse ambiental, os objetivos apresentados nos PD acabam perdendo a eficácia.

De acordo com Meurer e Vieira (2010) os municípios de pequeno porte apresentam dificuldades no estabelecimento de diretrizes e instrumentos quanto ao seu desenvolvimento, pois não ocorre à elaboração do zoneamento do uso do solo e a maior parte não possui PD, ou quando possui este se encontra desatualizado. Segundo os autores, nestes municípios não há investimento em ações de planejamento que contemplem um período de médio e longo prazo.

Os problemas que ocorrem nos PDs estão relacionados com maior frequência com as seguintes áreas temáticas: desenvolvimento do setor econômico regional; reparação de áreas centrais da cidade; avaliação em áreas rurais; políticas de habitação; regularização fundiária; aspectos relacionados à mobilidade urbana; saneamento; estudos de impactos de vizinhança; e outros aspectos relacionados ao uso e ocupação do solo (MINISTÉRIO DAS CIDADES, 2004).

\subsubsection{Unidades de conservação}

De acordo com Hockings et al. (2006) o sucesso das áreas protegidas como uma ferramenta para a conservação é fundamentado na hipótese de que elas são gerenciadas para proteger os seus valores. A gestão eficaz depende das características específicas da própria localidade, sendo que cada área protegida apresenta uma variedade de funções biológicas e sociais, bem como as suas pressões e utilizações.

Em 2014 existiam 209.429 áreas protegidas no mundo, este número corresponde a uma área total de $32.868 .673 \mathrm{~km}^{2}$. A Tabela 1 apresenta a quantidade em números e em km² das áreas protegidas mundiais desde o ano de 1962 e a Figura 1 apresenta o percentual destas áreas distribuídas no mundo (DEGUIGNET et al., 2014).

Tabela 1 - Áreas protegidas no mundo.

\begin{tabular}{c|c|c}
\hline Ano & Número de Áreas Protegidas & Total das Áreas Protegidas $\left.\mathbf{( k m}^{\mathbf{2}}\right)$ \\
\hline 1962 & 9.214 & 2.400 .000 \\
\hline 1972 & 16.394 & 4.100 .000 \\
\hline 1982 & 27.794 & 8.800 .000 \\
\hline 1992 & 48.388 & 12.300 .000 \\
\hline 2003 & 102.102 & 18.800 .000 \\
\hline 2014 & 209.429 & 32.868 .673 \\
\hline
\end{tabular}

Fonte: Adaptado de Deguignet et al. (2014). 
Figura 1 - Percentual das áreas protegidas no mundo.

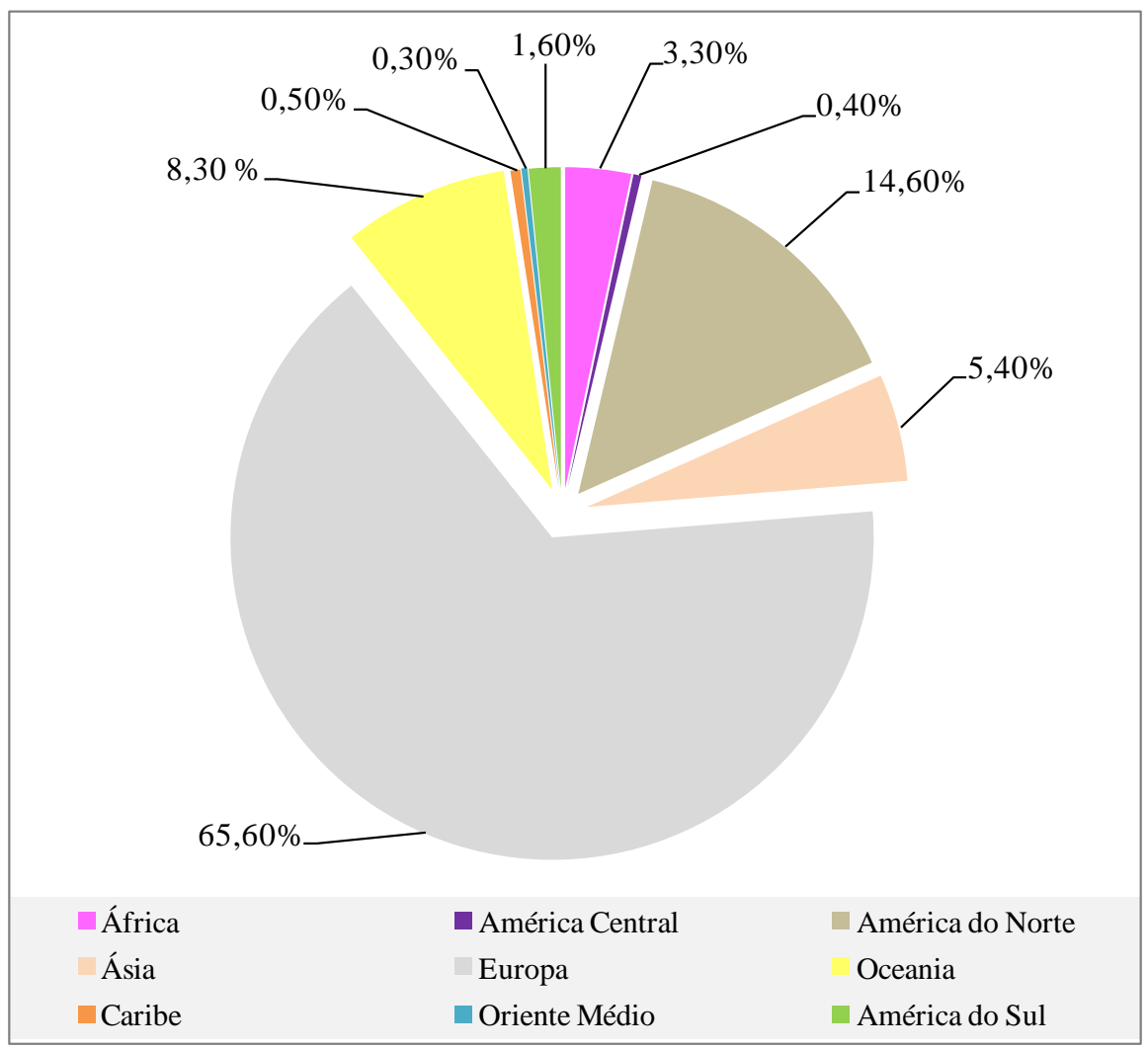

Fonte: Modificado de Deguignet et al. (2014).

As Unidades de Conservação (UC) tiveram seu início em 1872, nos Estados Unidos, com a criação do Parque Nacional de Yellowstone. A partir de então, outros países começaram a se preocupar com a questão de preservar as suas áreas naturais, como: Canadá em 1885; Nova Zelândia em 1894; México, Austrália e África do Sul em 1898. Na América do Sul os primeiros a apresentar interesse foram: a Argentina em 1903, logo após o Chile em 1926, o Equador em 1934 e a Venezuela em 1937 (MILANO, 2001).

Conforme Foleto e Ziani (2013) a partir do século XX começaram a intensificar a criação das áreas protegidas, devido à preocupação da sociedade com a conservação da biodiversidade do planeta e com os problemas ambientais. Neste contexto, os autores defendem a necessidade das ações de planejamento, de forma a assegurar a continuação dos serviços ambientais, bem como garantir a proteção dos espaços naturais. A delimitação dos espaços territoriais protegidos começou a ser considerada como o principal instrumento da PNMA (Lei n 6.938/1981). Para os autores, a definição de áreas protegidas é considerada um termo abrangente, referindo-se a diversas tipologias, como as áreas de preservação permanente (APPs), a reserva legal, bem como as UCs. 
O cuidado com o estabelecimento de áreas protegidas no Brasil começou no ano de 1937, com a criação do Parque Nacional de Itatiaia. Contudo, somente na década de 80, o movimento ganhou respaldo político e começaram a ser implementadas outras unidades, como exemplo, a Estação Ecológica Jureia-Itatins, Reserva Biológica do Atol das Rocas, Parque Nacional dos Abrolhos e Parque Nacional Marinho de Fernando de Noronha (BANZATO, 2014). No período de 1940 a 1958 não ocorreu à criação de novas UCs, em 1959 este processo retornou com a implantação dos parques Araguaia, Ubajara e Aparados da Serra, estes foram criados com a função de proteger as belezas naturais presentes nestas áreas (SANTOS, 2011).

No ano de 2000 no Brasil foi promulgada a Lei Federal $n^{\circ} 9.985$ que constitui o Sistema Nacional de Unidade de Conservação da Natureza (SNUC). Segundo esta legislação, as UCs são compreendidas por um espaço territorial e seus recursos ambientais, englobando as águas jurisdicionais, com importantes características naturais, tendo como objetivos a conservação e os limites definidos, sob o regime especial de administração (BRASIL, 2000).

O SNUC apresenta doze categorias diferentes de UCs, sendo que dentre este contingente, cinco são consideradas UCs de Proteção Integral e as sete categorias restantes representam as UCs de Uso Sustentável. As categorias do primeiro grupo apresentam a funcionalidade de preservar a natureza permitindo indiretamente o uso dos recursos naturais, ou seja, não liberando o consumo, coleta, ou qualquer tipo de prejuízo desses recursos, assegurando apenas as atividades de recreação, lazer e trabalhos científicos. Já as UCs do segundo grupo visam conciliar a conservação da natureza com a utilização sustentável dos recursos naturais (BRASIL, 2000). A Figura 2 apresenta os tipos de UCs e suas respectivas categorias.

Figura 2 - Tipos de unidades de conservação com suas respectivas categorias.

\begin{tabular}{|l|l|}
\hline \multicolumn{2}{|c|}{ Tipos de Unidades de Conservação } \\
\cline { 1 - 2 } & \multicolumn{1}{|c|}{ Uso Sustentável } \\
\hline \multicolumn{1}{|c|}{ Proteção Integral } & \multicolumn{1}{c|}{ - Área de Proteção Ambiental } \\
-Estação Ecológica & - Área de Relevante Interesse Ecológico \\
- Reserva Biológica & - Floresta Nacional \\
- Parque Nacional & - Reserva Extrativista \\
- Monumento Natural & - Reserva de Fauna \\
- Refúgio de Vida Silvestre & - Reserva de Desenvolvimento Sustentável \\
& - Reserva Particular do Patrimônio Natural \\
\hline
\end{tabular}


De acordo com a Lei Federal $\mathrm{n}^{\circ}$ 9.985/2000 as UCs apresentam 13 objetivos, conforme apresenta a Tabela 2. A Tabela 3 apresenta os objetivos e a utilidade de cada uma das categorias dos dois tipos de unidades de conservação.

Tabela 2 - Objetivos das unidades de conservação, conforme o artigo $4^{\circ}$ da Lei Federal de 9.985/2000.

\section{Objetivos das Unidades de Conservação}

Art. $4^{\circ}$ da Lei Federal n $n^{\circ}$ 9.985/2000

I - Contribuir para a manutenção da diversidade biológica e dos recursos genéticos no território nacional e nas águas jurisdicionais

II - Proteger as espécies ameaçadas de extinção no âmbito regional e nacional

III - Contribuir para a preservação e a restauração da diversidade de ecossistemas naturais

IV - Promover o desenvolvimento sustentável a partir dos recursos naturais

V - Promover a utilização dos princípios e práticas de conservação da natureza no processo de desenvolvimento

VI - Proteger paisagens naturais e pouco alteradas de notável beleza cênica

VII - Proteger as características relevantes de natureza geológica, geomorfológica, espeleológica, arqueológica, paleontológica e cultural

VIII - Proteger e recuperar recursos hídricos e edáficos

IX - Recuperar ou restaurar ecossistemas degradados

$\mathrm{X}$ - Proporcionar meios e incentivos para atividades de pesquisa científica, estudos e monitoramento ambiental

XI - Valorizar econômica e socialmente a diversidade biológica

XII - Favorecer condições e promover a educação e interpretação ambiental, a recreação em contato com a natureza e o turismo ecológico

XIII - Proteger os recursos naturais necessários à subsistência de populações tradicionais, respeitando e valorizando seu conhecimento e sua cultura e promovendo-as social e economicamente

Fonte: Lei Federal no 9.985/2000. 
Tabela 3 - Objetivos e uso dos tipos de unidades de conservação.

\begin{tabular}{|c|c|c|c|}
\hline & Categoria & Objetivo & Uso \\
\hline \multirow{5}{*}{ 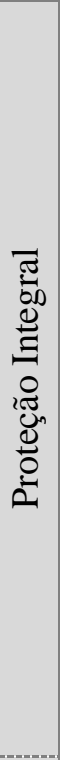 } & Estação Ecológica & Preservar e pesquisar & $\begin{array}{l}\text { Pesquisas científicas, visitação } \\
\text { pública com objetivos educacionais }\end{array}$ \\
\hline & Reserva Biológica & $\begin{array}{l}\text { Preservar a biota (seres vivos) e } \\
\text { demais atributos naturais, sem } \\
\text { interferência humana direta ou } \\
\text { modificações ambientais }\end{array}$ & $\begin{array}{l}\text { Pesquisas científicas, visitação } \\
\text { pública com objetivos educacionais }\end{array}$ \\
\hline & Parque Nacional & $\begin{array}{l}\text { Preservar ecossistemas naturais } \\
\text { de grande relevância ecológica } \\
\text { e beleza cênica. }\end{array}$ & $\begin{array}{l}\text { Pesquisas científicas, } \\
\text { desenvolvimento de atividades de } \\
\text { educação e interpretação ambiental, } \\
\text { recreação em contato com a } \\
\text { natureza e turismo ecológico }\end{array}$ \\
\hline & $\begin{array}{l}\text { Monumento } \\
\text { Natural }\end{array}$ & $\begin{array}{l}\text { Preservar sítios naturais raros, } \\
\text { singulares ou de grande beleza } \\
\text { cênica }\end{array}$ & Visitação pública \\
\hline & $\begin{array}{l}\text { Refúgio de Vida } \\
\text { Silvestre }\end{array}$ & $\begin{array}{l}\text { Proteger ambientes naturais e } \\
\text { assegurar a existência ou } \\
\text { reprodução da flora ou fauna }\end{array}$ & $\begin{array}{l}\text { Pesquisa científica e visitação } \\
\text { pública }\end{array}$ \\
\hline \multirow{7}{*}{ 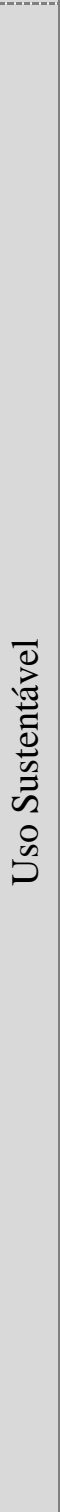 } & $\begin{array}{l}\text { Área de Proteção } \\
\text { Ambiental }\end{array}$ & $\begin{array}{l}\text { Proteger a biodiversidade, } \\
\text { disciplinar o processo de } \\
\text { ocupação e assegurar a } \\
\text { sustentabilidade do uso dos } \\
\text { recursos naturais }\end{array}$ & $\begin{array}{l}\text { São estabelecidas normas e } \\
\text { restrições para a utilização de uma } \\
\text { propriedade privada localizada em } \\
\text { uma área de Proteção Ambiental }\end{array}$ \\
\hline & $\begin{array}{l}\text { Área de Relevante } \\
\text { Interesse Ecológico }\end{array}$ & $\begin{array}{l}\text { Manter os ecossistemas } \\
\text { naturais e regular o uso } \\
\text { admissível dessas áreas }\end{array}$ & $\begin{array}{l}\text { Respeitados os limites } \\
\text { constitucionais, podem ser } \\
\text { estabelecidas normas e restrições } \\
\text { para utilização de uma propriedade } \\
\text { privada localizada em uma Área de } \\
\text { Relevante Interesse Ecológico }\end{array}$ \\
\hline & Floresta Nacional & $\begin{array}{l}\text { Uso múltiplo sustentável dos } \\
\text { recursos florestais para a } \\
\text { pesquisa científica, com ênfase } \\
\text { em métodos para exploração } \\
\text { sustentável de florestas nativas }\end{array}$ & $\begin{array}{l}\text { Visitação, pesquisa científica e } \\
\text { manutenção de populações } \\
\text { tradicionais }\end{array}$ \\
\hline & $\begin{array}{l}\text { Reserva } \\
\text { Extrativista }\end{array}$ & $\begin{array}{l}\text { Proteger os meios de vida e a } \\
\text { cultura das populações } \\
\text { extrativistas tradicionais, e } \\
\text { assegurar o uso sustentável dos } \\
\text { recursos naturais }\end{array}$ & $\begin{array}{l}\text { Extrativismo vegetal, agricultura de } \\
\text { subsistência e criação de animais de } \\
\text { pequeno porte. Visitação pode ser } \\
\text { permitida }\end{array}$ \\
\hline & Reserva de Fauna & $\begin{array}{l}\text { Preservar populações animais } \\
\text { de espécies nativas, terrestres } \\
\text { ou aquáticas, residentes ou } \\
\text { migratórias }\end{array}$ & Pesquisa científica \\
\hline & $\begin{array}{l}\text { Reserva de } \\
\text { Desenvolvimento } \\
\text { Sustentável }\end{array}$ & $\begin{array}{l}\text { Preservar a natureza e } \\
\text { assegurar as condições } \\
\text { necessárias para a reprodução e } \\
\text { melhoria dos modos e da } \\
\text { qualidade de vida das } \\
\text { populações tradicionais }\end{array}$ & $\begin{array}{l}\text { Exploração sustentável de } \\
\text { componentes do ecossistema. } \\
\text { Visitação e pesquisas científicas } \\
\text { podem ser permitidas. }\end{array}$ \\
\hline & $\begin{array}{l}\text { Reserva Particular } \\
\text { do Patrimônio } \\
\text { Natural }\end{array}$ & $\begin{array}{l}\text { Conservar a diversidade } \\
\text { biológica }\end{array}$ & $\begin{array}{l}\text { Pesquisa científica, atividades de } \\
\text { educação ambiental e turismo }\end{array}$ \\
\hline
\end{tabular}

Fonte: Adaptado de WWF (2016). 
De acordo com Pellizzaro et al. (2015) são apresentadas na Tabela 4 as principais funções de sete categorias de manejo, com base no grau de naturalidade das áreas protegidas, bem como nas suas atividades.

Estes autores enfatizam a importância da integração entre a proteção de atributos do meio natural e cultural, sendo aspectos associados no atual conceito de áreas naturais protegidas, sendo que, dentre as várias funcionalidades propostas para as categorias de manejo, a Reserva Natural e Área Silvestre são as duas únicas em que não são sugeridas a proteção ou manutenção de características naturais e culturais.

Tabela 4 - Principais funções das categorias de manejo das áreas protegidas recomendadas pela International Union for Conservation of Nature (IUCN, 2003).

\begin{tabular}{|c|c|c|c|c|c|c|c|c|}
\hline \multicolumn{2}{|r|}{ Cateoorias de Man } & Ia & $\mathrm{Ib}$ & II & III & IV & $\mathrm{V}$ & VI \\
\hline \multicolumn{2}{|l|}{ Investigação científica } & 1 & 3 & 2 & 2 & 2 & 2 & 3 \\
\hline \multicolumn{2}{|c|}{ Proteção de zonas silvestres } & 2 & 1 & 2 & 3 & 3 & - & 2 \\
\hline \multicolumn{2}{|c|}{ Preservação de espécies e da diversidade genética } & 1 & 2 & 1 & 1 & 1 & 2 & 1 \\
\hline \multicolumn{2}{|c|}{ Manutenção dos serviços ambientais } & 2 & 1 & 1 & - & 1 & 2 & 1 \\
\hline \multicolumn{2}{|c|}{ Proteção de características naturais e culturais específicas } & - & - & 2 & 1 & 3 & 1 & 3 \\
\hline \multicolumn{2}{|l|}{ Turismo e recreação } & - & 2 & 1 & 1 & 3 & 1 & 3 \\
\hline \multicolumn{2}{|l|}{ Educação ambiental } & - & - & 2 & 2 & 2 & 2 & 3 \\
\hline \multicolumn{2}{|l|}{ Uso sustentável } & - & 3 & 3 & - & 2 & 2 & 1 \\
\hline \multicolumn{2}{|c|}{ Manutenção dos atributos culturais } & - & - & - & - & - & 1 & 2 \\
\hline $\begin{array}{l}\text { Legenda: } \\
\text { Ia - Reserva Natural } \\
\text { Ib - Área Silvestre } \\
\text { II - Parque Nacional } \\
\text { III - Monumento Natural }\end{array}$ & $\begin{array}{l}\text { IV - Santuário de Vida Silvestre } \\
\text { V - Paisagem Terrestre / Marinha } \\
\text { Protegida } \\
\text { VI - Areas Protegidas com Recursos } \\
\text { Manejados }\end{array}$ & $\begin{array}{l}1 \\
2 \\
3 \\
-\end{array}$ & $\begin{array}{l}\text { Objeti } \\
\text { Objeti } \\
\text { Objeti } \\
\text { Objeti }\end{array}$ & $\begin{array}{l}\text { ter } \\
\text { inc }\end{array}$ & $\begin{array}{l}\text { pal } \\
\text { dário } \\
\text { tio } \\
\text { patív }\end{array}$ & com & cate & \\
\hline
\end{tabular}

Fonte: Modificado de Pellizzaro et al. (2015).

As Tabelas 5 e 6 apresentam o número de UC de proteção integral e de uso sustentável no Brasil, conforme o Cadastro Nacional de Unidade de Conservação (CNUC), considerando as esferas federal, estadual e municipal. 
Tabela 5 - Número e área $\left(\mathrm{km}^{2}\right)$ das unidades de conservação de proteção integral.

\begin{tabular}{|c|c|c|c|}
\hline \multicolumn{4}{|c|}{ Proteção Integral } \\
\hline \multirow{2}{*}{ Tipo/Categoria } & \multicolumn{3}{|c|}{ Esfera } \\
\hline & Federal & Estadual & Municipal \\
\hline Estação Ecológica & 32 & 58 & 1 \\
\hline Monumento Natural & 3 & 28 & 11 \\
\hline Parque Nacional / Estadual / Municipal & 71 & 195 & 95 \\
\hline Refúgio de Vida Silvestre & 7 & 24 & 1 \\
\hline Reserva Biológica & 30 & 24 & 6 \\
\hline Total & $\begin{array}{c}\mathrm{N}^{0}: 143 \\
\text { Área: } \\
369.164 \mathrm{~km}^{2}\end{array}$ & $\begin{array}{c}\mathrm{N}^{\mathrm{o}}: 329 \\
\text { Área: } \\
\text { 158.472 Km² }\end{array}$ & $\begin{array}{l}\mathrm{N}^{0}: 114 \\
\text { Área: } \\
372 \text { km² }^{2}\end{array}$ \\
\hline
\end{tabular}

Fonte: Adaptado de MMA/CNUC (2016).

Tabela 6 - Número e área $\left(\mathrm{km}^{2}\right)$ das unidades de conservação de uso sustentável.

\begin{tabular}{|c|c|c|c|}
\hline \multicolumn{4}{|c|}{ Uso Sustentável } \\
\hline \multirow{2}{*}{ Tipo/Categoria } & \multicolumn{3}{|c|}{ Esfera } \\
\hline & Federal & Estadual & Municipal \\
\hline Floresta Nacional / Estadual / Municipal & 65 & 39 & 0 \\
\hline Reserva Extrativista & 62 & 28 & 0 \\
\hline Reserva de Desenvolvimento Sustentável & 2 & 29 & 5 \\
\hline Reserva de Fauna & 0 & 0 & 0 \\
\hline Área de Proteção Ambiental & 32 & 185 & 77 \\
\hline Área de Relevante Interesse Ecológico & 16 & 24 & 8 \\
\hline Reserva Particular de Patrimônio Natural & 634 & 147 & 1 \\
\hline Total & $\begin{array}{c}\mathrm{N}^{0}: 811 \\
\text { Área: } \\
394.681 \mathrm{~km}^{2}\end{array}$ & $\begin{array}{c}\mathrm{N}^{\circ}: 452 \\
\text { Área: } \\
755.661 \mathrm{~km}^{2}\end{array}$ & $\begin{array}{c}N^{\circ}: 91 \\
\text { Área: } \\
26.479 \text { km }^{2}\end{array}$ \\
\hline
\end{tabular}

Fonte: Adaptado de MMA/CNUC (2016).

\subsubsection{Zonas de manejo de parques nacionais}

Conforme estabelece a Lei Federal $n^{\circ} 9.985 / 2000$ as UCs de proteção integral envolvem os parques nacionais, e estes podem ser divididos em doze zonas, de acordo com o roteiro metodológico de planejamento, elaborado pelo IBAMA (2002). Este procedimento é efetuado para identificar dentre as áreas da unidade quais necessitam de cuidados emergenciais quanto ao uso irracional dos seus recursos naturais. Logo, são apresentadas as zonas e uma simples referência de cada uma delas. 
- Zona Intangível: a área considerada mais preservada e que tem como objetivo principal a preservação, com a finalidade de garantir a evolução natural. Nesta zona não é permitido nenhuma modificação causada por atividades antrópicas, pois a área funciona como matriz de repovoamento de outras zonas. Esta zona é destinada para proteger integralmente os ecossistemas, além dos recursos genéticos;

- Zona Primitiva: área que ocorreu pouca intervenção antrópica, tem como função preservar o ambiente natural e proporcionar maior facilidade as atividades de pesquisa científica e educação ambiental;

- Zona de Uso Extensivo: em sua maioria são áreas naturais, tendo como objetivo a manutenção do ambiente natural com o mínimo de intervenção antrópica, porém permitindo o acesso público para fins educativos e recreativos;

- Zona de Uso Intensivo: concede a implementação de infraestrutura de visitação e serviços, mas visa conservar a área o mais natural possível;

- Zona Histórico-cultural: área em que estão situadas as amostras do patrimônio histórico/cultural ou arqueopaleontógico, que poderão ser utilizadas para ensino e pesquisas científicas, no entanto necessitam de certos cuidados, como preservação e restauração.

- Zona de Recuperação: é considerada como uma área temporária, na qual apenas é permitida a utilização pública para meios educativos. Compreendem áreas visivelmente modificadas pelas ações humanas, que são responsáveis em interromper a degradação dos recursos ou até mesmo restaurar a área. Caso a área for restaurada, esta passará a fazer parte de outra zona permanente;

- Zona de Uso Especial: trata-se de áreas necessárias à administração, manutenção e serviços da UC;

- Zona de Uso Conflitante: são áreas dentro das limitações da unidade de conservação, cujos usos e finalidades encontrados antes da criação da área protegida opõem com os objetivos de conservação da área;

- Zona de Ocupação Temporária: são áreas situadas dentro das unidades de conservação onde residem populações humanas e se encontram as suas áreas de uso. É considerada uma zona provisória, que depois de realocada a população, será inserida em uma das zonas permanentes; 
- Zona de Superposição Indígena: são as áreas ocupadas por uma ou mais etnias indígenas. São áreas que dependem de um regime especial de regulamentação, que envolve tanto a etnia indígena, como a Fundação Nacional do Índio (FUNAI) e o Instituto Brasileiro do Meio Ambiente e dos Recursos Naturais Renováveis (IBAMA) para negociação;

- Zona de Interferência Experimental: são constituídas por áreas naturais ou aquelas que já sofreram alguma mudança oriunda da ação humana, são áreas próprias para as estações ecológicas. O seu objetivo é a realização de pesquisas que permitem a comparação em áreas preservadas;

- Zona de Amortecimento: corresponde a área que envolve a UC, na qual as atividades humanas estão sujeitas a normas e restrições legais de uso, com a finalidade de diminuir os impactos negativos sobre a UC.

Para Lima (2008) as áreas que envolvem às UCs apresentam distintas classificações, sendo denominadas de "zonas de amortecimento", "zonas tampões", "áreas de entorno" e "buffer". Conforme a autora, na prática estes termos podem ser considerados iguais, as várias nomenclaturas se justificam por terem sido utilizadas em períodos e legislações diferentes. Como exemplo, o "buffer", é o termo mais utilizado em trabalhos realizados por técnicas de geoprocessamento.

De acordo com Siqueira (2017) as possíveis zonas presentes nos diferentes tipos de unidades de conservação estão apresentadas na Tabela 7.

Tabela 7 - Possíveis zonas existentes nos diferentes tipos de UCs.

\begin{tabular}{|c|c|c|c|c|c|}
\hline $\begin{array}{l}\text { Zonas de Unidades de } \\
\text { Conservação }\end{array}$ & $\begin{array}{l}\text { Parque } \\
\text { Nacional }\end{array}$ & $\begin{array}{l}\text { Reserva } \\
\text { Biológica }\end{array}$ & $\begin{array}{l}\text { Estação } \\
\text { Ecológica }\end{array}$ & $\begin{array}{c}\text { Reserva } \\
\text { Particular } \\
\text { do } \\
\text { Patrimônio } \\
\text { Natural }\end{array}$ & $\begin{array}{c}\text { Área de } \\
\text { Proteção } \\
\text { Ambiental }\end{array}$ \\
\hline Zona Intangível & $\mathrm{x}$ & $\mathrm{X}$ & $\mathrm{X}$ & & \\
\hline Zona Primitiva & $\mathrm{x}$ & $\mathrm{x}$ & $\mathrm{x}$ & & \\
\hline Zona de Uso Extensivo & $\mathrm{x}$ & $\mathrm{x}$ & $\mathrm{x}$ & & \\
\hline Zona de Uso Intensivo & $\mathrm{x}$ & $\mathrm{x}$ & $\mathrm{x}$ & & \\
\hline Zona Histórico-Cultural & $\mathrm{X}$ & $\mathrm{X}$ & $\mathrm{x}$ & & \\
\hline Zona de Recuperação/Restauração & $\mathrm{x}$ & $\mathrm{x}$ & $\mathrm{x}$ & $\mathrm{X}$ & \\
\hline Zona de Uso Especial & $\mathrm{x}$ & $\mathrm{x}$ & $\mathrm{x}$ & & \\
\hline
\end{tabular}

Fonte: Modificado de Siqueira (2017). 
Tabela 7 - Possíveis zonas existentes nos diferentes tipos de UCs (continuação).

\begin{tabular}{c|c|c|c|c|c}
\hline $\begin{array}{c}\text { Zonas de Unidades de } \\
\text { Conservação }\end{array}$ & $\begin{array}{c}\text { Parque } \\
\text { Nacional }\end{array}$ & $\begin{array}{c}\text { Reserva } \\
\text { Biológica }\end{array}$ & $\begin{array}{c}\text { Estação } \\
\text { Ecológica }\end{array}$ & $\begin{array}{c}\text { Reserva } \\
\text { Particular } \\
\text { do } \\
\text { Patrimônio } \\
\text { Natural }\end{array}$ & $\begin{array}{c}\text { Área de } \\
\text { Proteção } \\
\text { Ambiental }\end{array}$ \\
\hline Zona de Uso Conflitante & $\mathrm{x}$ & $\mathrm{x}$ & $\mathrm{x}$ & & \\
\hline Zona de Ocupação Temporária & $\mathrm{x}$ & $\mathrm{x}$ & $\mathrm{x}$ & & \\
\hline Zona de Superposição Indígena & $\mathrm{x}$ & $\mathrm{x}$ & $\mathrm{x}$ & & \\
\hline $\begin{array}{c}\text { Zona de Interferência } \\
\text { Experimental }\end{array}$ & $\mathrm{x}$ & $\mathrm{x}$ & $\mathrm{x}$ & & $\mathrm{x}$ \\
\hline Zona Silvestre & & & & $\mathrm{x}$ & \\
\hline Zona de Proteção & & & & & \\
\hline Zona de Visitação & & & & & \\
\hline Zona de Administração & & & & & \\
\hline Zona de Transição & & & & & \\
\hline Zona de Preservação & & & & & \\
\hline Zona de Manejo Florestal \\
Comunitário & & & & & \\
\hline Zona de Manejo Sustentável & & & & & \\
\hline Zona de Uso Público & & & & & \\
\hline Zona Populacional & & & & & \\
\hline Zona de Amortecimento & $\mathrm{x}$ & & & & \\
\hline
\end{tabular}

Fonte: Modificado de Siqueira (2017).

\subsubsection{Plano de manejo}

Frente às categorias das UCs expostas na legislação brasileira, os Parques Nacionais possuem importância central, pois se destacam como uma das categorias de proteção que está associada à preservação ambiental de extensas áreas, diferente das demais categorias, como as áreas de proteção ambiental, reserva extrativista, terras indígenas, reserva legal, que de certa forma, são áreas que aceitam o uso mais intensivo dos recursos existentes. Por conseguinte, para o fortalecimento do sistema das áreas de preservação ambiental e a sua biodiversidade é indispensável conhecer o Plano de Manejo (PM) como um dos instrumentos de gestão ambiental mais antigo, que por sua vez também é obrigatório legalmente, visto que foi instituído em 1979 (PEREIRA, 2009). 
A Lei Federal $n^{\circ}$ 9.985/2000, define o PM como um documento técnico, com fundamento nos objetivos gerais de uma UC, estabelecendo o seu zoneamento e as normas que devem presidir o uso da área e o manejo dos recursos naturais. Ressalta que o plano deverá envolver toda a área da UC, a zona de amortecimento e os corredores ecológicos, além de medidas que estimulem sua integração com o meio econômico e social das áreas circunvizinhas (BRASIL, 2000).

O PM se constitui no principal instrumento na estrutura gerencial da UC, que envolve tanto o zoneamento como também as normas que restringem os usos inadequados da área, buscando sempre práticas de conservação. Para o cumprimento dos objetivos deste documento é necessário que o planejamento seja contínuo, pois abrange constantemente a busca de conhecimento para guardar a proposta de manejo mais atual, visto que cada nova fase abrangerá os princípios e ações da fase anterior; gradativo, por causa da evolução dos conhecimentos no que diz respeito aos recursos naturais e também culturais da UC, característica que determina a capacidade do documento; flexível, pois pode agregar novos conhecimentos e correções ao PM na implementação de qualquer uma das fases; participativo, devido envolver a sociedade no planejamento (IBAMA, 2002).

Segundo Muruthi (2006) um PM é um documento que tem como objetivo orientar o uso e controlar os recursos dentro de uma área protegida. É definido como um instrumento dinâmico e prático que mostra a realidade da área em questão, com base na análise de fatores ambientais e socioeconômicos, além de citar medidas gerais para a conservação, e para a elaboração do zoneamento. Este tipo de plano oferece orientações em três dimensões: espaço, de forma a estabelecer o que deve ser realizado em um local específico; tempo, visa o que deve ser feito em um determinado período e o método, que constitui como deve ser realizada cada etapa proposta no PM.

Segundo Thomas et al. (2011) para assegurar a conservação da biodiversidade e dos atributos ambientais das UCs, foi definido pelo poder público que estas áreas tem a obrigação de elaborar um PM. Para o autor, este plano é semelhante ao PD, entretanto, institui normas e diretrizes para a UC. No PM serão contempladas as ações que poderão ser realizadas na área, de forma que o uso seja adequado para fins da unidade, bem como a sua categoria de manejo.

O PM apresenta três abordagens, sendo elas: enquadramento, diagnóstico e proposições. No que diz a respeito à primeira abordagem, associa-se o enquadramento da unidade nas esferas de competência internacional, federal e estadual, apresentando-se a sua 
relevância nestes âmbitos. Com relação ao diagnóstico, tem-se a caracterização e a situação social e ambiental da área. A terceira abordagem concentra-se na minimização dos conflitos e também em estabelecer melhorias para a área, através de um planejamento (IBAMA, 2002).

De acordo com Cavalcanti (2010), o planejamento físico e ambiental depende de uma relação com as atividades produtivas e com a criação de novos espaços de ocupação. Com base neste contexto, os PMs e de gestão são utilizados com a finalidade de organizar o espaço territorial, estimulando a recuperação ecológica e também econômica das iniciativas estabelecidas, buscando harmonizar as políticas ambientais e o desenvolvimento da região.

Segundo Hockings et al. (2006) uma gestão eficaz necessita de ser embasada em uma compreensão completa de condições individuais de uma área protegida. Os autores apresentam algumas questões importantes para serem consideradas em um plano de gestão. A Figura 3 apresenta a estrutura de avaliação da eficácia da gestão de uma área protegida.

Figura 3 - Estrutura de avaliação da gestão de uma área protegida.

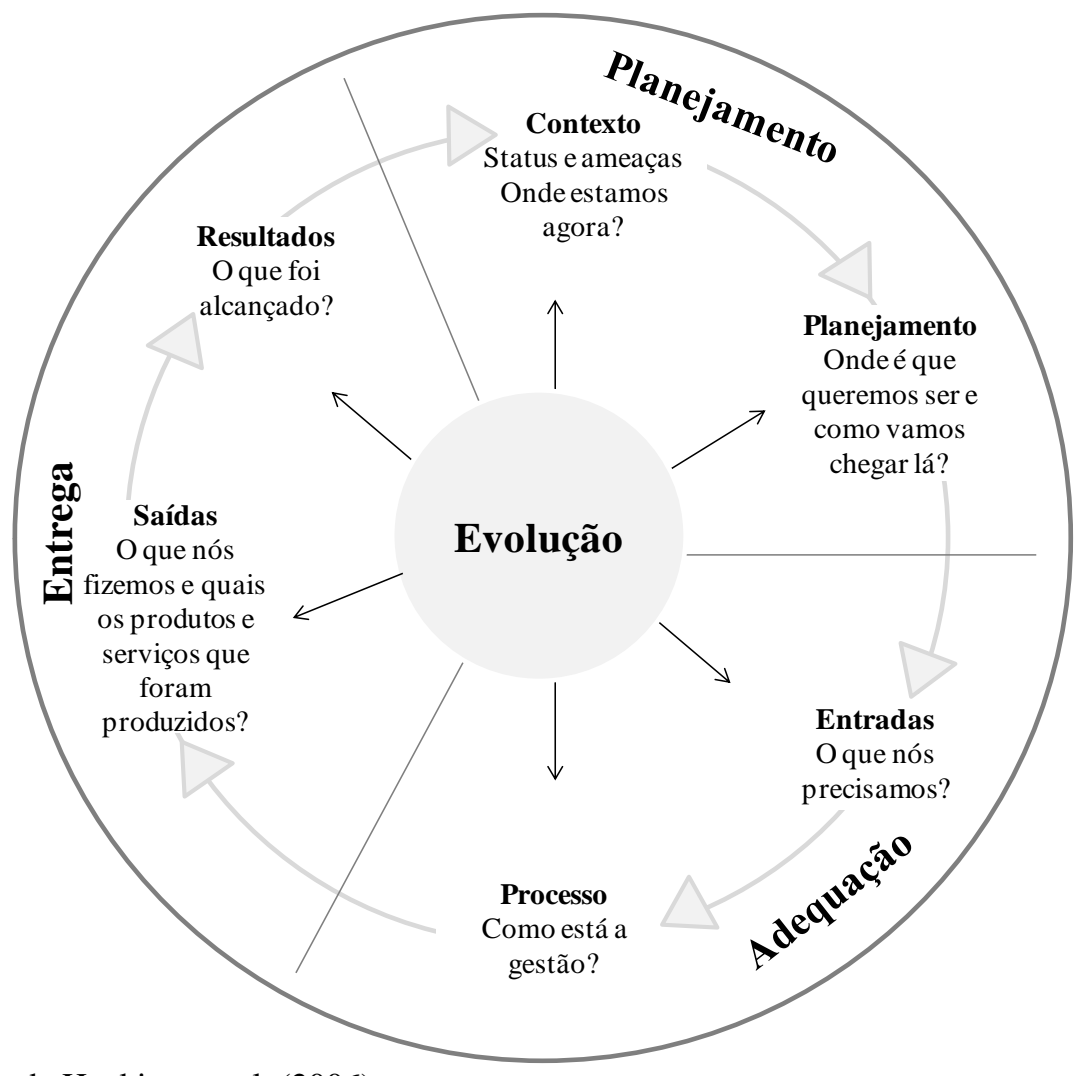

Fonte: Modificado de Hockings et al. (2006).

Segundo IBAMA (2002), o PM é dividido em seis etapas, como apresenta a Figura 4, sendo que as quatro primeiras etapas correspondem a fase de diagnóstico e planejamento, as duas últimas são responsáveis pela fase de implementação do documento, ressaltando que a 
quinta etapa (projetos específicos) é essencial para as duas fases (diagnóstico e implementação).

Figura 4 - Etapas de um plano de manejo de uma unidade de conservação.

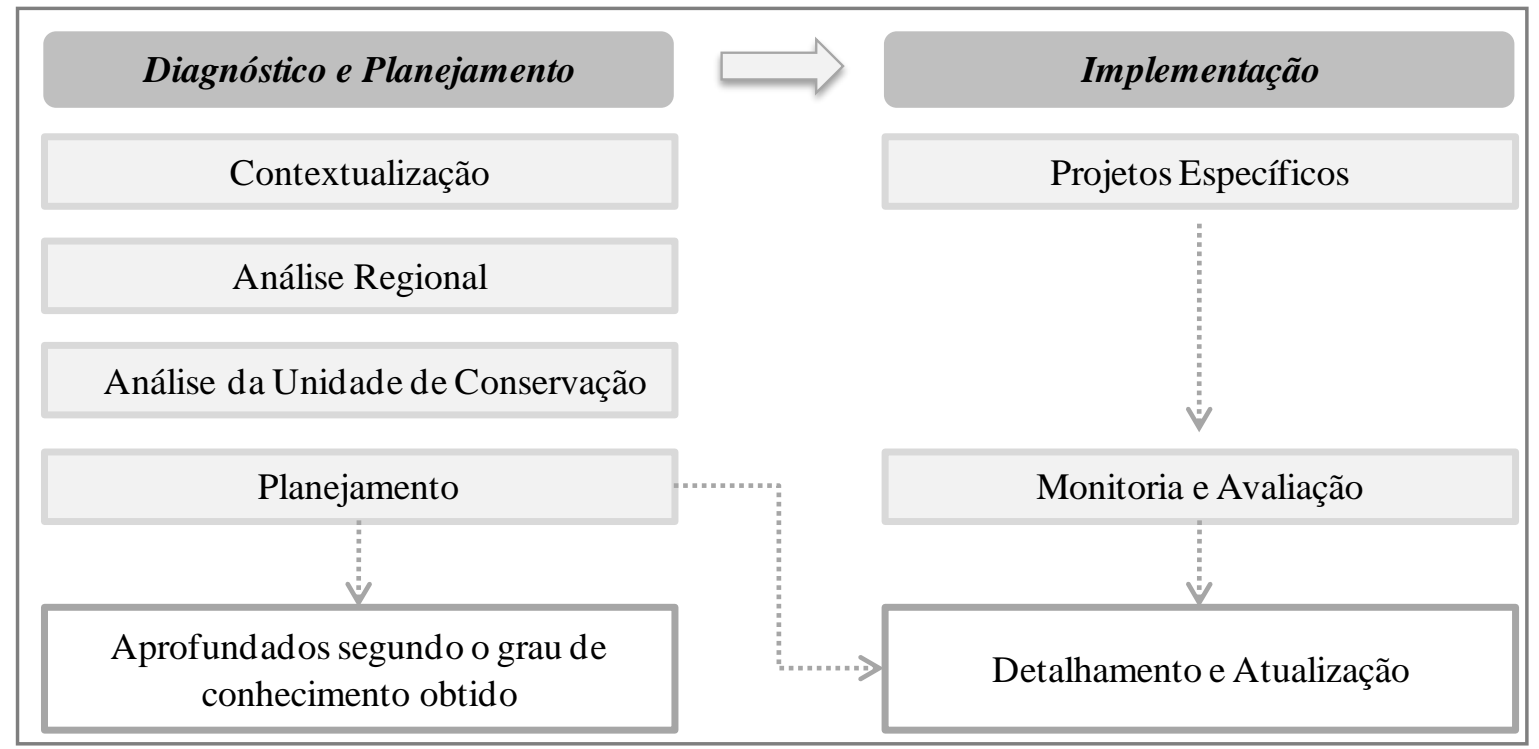

Fonte: Adaptado de IBAMA (2002).

Assim como no Brasil, os PM são obrigatórios em outros países, utilizados para auxiliar a gestão ambiental das UCs de forma a garantir um melhor planejamento e gerenciamento da área, além de contribuir em manter as características naturais restringindo certos usos de seus recursos.

A Tabela 8 apresenta algumas informações sobre alguns PM de parques nacionais e internacionais. Vale ressaltar que a escolha destes planos não foi embasada em nenhum critério específico. 
Tabela 8 - Informações sobre alguns planos de manejos de unidades de conservação nacionais e internacionais.

\begin{tabular}{|c|c|c|c|}
\hline Par & $\begin{array}{c}\text { Ano do Plano } \\
\text { Manejo }\end{array}$ & ocal & Informações \\
\hline $\begin{array}{l}\text { Parque } \\
\text { Nacional } \\
\text { de Itatiaia }\end{array}$ & $\begin{array}{l}\text { - Primeiro plano } \\
\text { elaborado em } 1937 \\
\text { - Última revisão e } \\
\text { publicação } \\
\text { ocorreram no ano } \\
\text { de } 2013 \text { (contempla } \\
\text { quatro volumes) }\end{array}$ & $\begin{array}{l}\text { - Municípios } \\
\text { de Bocaina } \\
\text { de Minas e } \\
\text { Itamonte no } \\
\text { Estado de } \\
\text { Minas Gerais } \\
\\
\text { - Municípios } \\
\text { de Itatiaia e } \\
\text { Resende no } \\
\text { Estado do } \\
\text { Rio de } \\
\text { Janeiro }\end{array}$ & $\begin{array}{l}\text { - O zoneamento da UC foi dividido em } 8 \text { classes, } \\
\text { visto que, a zona que não foi considerada no parque } \\
\text { está relacionada com o patrimônio histórico- } \\
\text { cultural. } \\
\text { - A zona que apresentou a maior representatividade } \\
\text { foi a "primitiva" correspondendo a } 56 \% \text { da área } \\
\text { total. Dentre as demais, a que apresentou em menor } \\
\text { percentual }(0,18 \%) \text { foi à zona de uso conflitante. } \\
\text { - Para a elaboração do mapa de zoneamento, foi } \\
\text { necessário analisar um grupo de parâmetros e } \\
\text { dentre os atributos do meio físico analisados foram: } \\
\text { clima, relevo/geomorfologia, geologia, solos, } \\
\text { hidrografia (ICMBio, 2013). }\end{array}$ \\
\hline $\begin{array}{l}\text { Parque } \\
\text { Nacional } \\
\text { da Serra } \\
\text { dos } \\
\text { Órgãos }\end{array}$ & 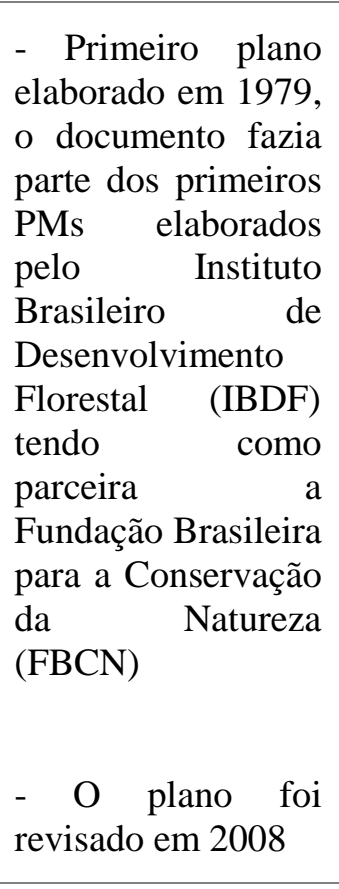 & $\begin{array}{l}\text { - Municípios } \\
\text { de Magé, } \\
\text { Guapimirim, } \\
\text { Petrópolis e } \\
\text { Teresópolis } \\
\text { no Estado do } \\
\text { Rio de } \\
\text { Janeiro }\end{array}$ & $\begin{array}{l}\text { - É considerado o terceiro parque mais antigo do } \\
\text { Brasil. } \\
\text { - O objetivo da elaboração do PM do PARNASO } \\
\text { foi garantir a proteção da paisagem deste trecho da } \\
\text { Serra do Mar e sua biodiversidade. } \\
\text { - O mapa de zoneamento foi elaborado } \\
\text { considerando uma área de aproximadamente } \\
20.025 \text { ha. } \\
\text { - A área foi dividida em nove zonas, dentre elas as } \\
\text { que não foram consideradas no decreto federal (n } \\
84.017 / 1979 \text { ) foram apenas a zona de uso } \\
\text { conflitante (as áreas ocupadas por } \\
\text { empreendimentos públicos, como gasodutos, } \\
\text { oleodutos, linhas de transmissão, antenas, captação } \\
\text { de água, barragens, estradas, cabos óticos, entre } \\
\text { outros) e a zona de ocupação temporária (áreas em } \\
\text { que se situam às populações humanas e suas } \\
\text { respectivas áreas de uso, sendo que uma vez } \\
\text { realocada à população, deve ser integrada a uma } \\
\text { das zonas permanentes) (ICMBio, 2008). }\end{array}$ \\
\hline $\begin{array}{c}\text { Parque } \\
\text { Nacional } \\
\text { da Serra } \\
\text { da } \\
\text { Canastra }\end{array}$ & $\begin{array}{l}\text { - O primeiro plano } \\
\text { foi elaborado em } \\
\text { 1981, somente para } \\
\text { a região do } \\
\text { Chapadão da } \\
\text { Canastra }\end{array}$ & $\begin{array}{l}\text { - Municípios } \\
\text { de São } \\
\text { Roque de } \\
\text { Minas, } \\
\text { Sacramento, } \\
\text { Delfinópolis, } \\
\text { São João } \\
\text { Batista do } \\
\text { Glória, } \\
\text { Capitólio e } \\
\text { Vargem } \\
\text { Bonita em } \\
\text { Minas Gerais }\end{array}$ & $\begin{array}{l}\text { - Para efeito deste documento o parque foi dividido } \\
\text { e analisado, em alguns tópicos, considerando duas } \\
\text { grandes áreas, denominadas Chapadão da Canastra } \\
\text { e Chapadão da Babilônia. } \\
\text { - A primeira área é considerada consolidada e } \\
\text { abrange } 71.525 \text { ha, na qual a situação fundiária } \\
\text { encontra-se regularizada. O segundo espaço ocupa } \\
\text { aproximadamente } 130.000 \text { ha da área decretada, } \\
\text { por sua vez não se encontra regularizada. } \\
\text { - O mapa de zoneamento do PNSC envolveu dez } \\
\text { classes e foi elaborado com base nos seguintes } \\
\text { critérios: espécies, diversidade, vulnerabilidade, } \\
\text { ocorrência de sítios arqueológicos e também outros } \\
\text { parâmetros que apresentam valor cultural, além } \\
\text { disso, envolveu as aptidões de uso, a infra-estrutura } \\
\text { e os usos conflitantes (IBAMA, 2005). }\end{array}$ \\
\hline
\end{tabular}


Tabela 8 - Informações sobre alguns planos de manejos de unidades de conservação nacionais e internacionais (continuação).

\begin{tabular}{|c|c|c|c|}
\hline Parques & $\begin{array}{c}\text { Ano do Plano } \\
\text { de Manejo }\end{array}$ & Local & Informações \\
\hline $\begin{array}{c}\text { Parque } \\
\text { Nacional } \\
\text { Croajingolong }\end{array}$ & $\begin{array}{ll}- \text { O plano de } \\
\text { manejo } & \text { foi } \\
\text { elaborado } & \text { em } \\
1996 & \end{array}$ & $\begin{array}{l}\text { Localizado } \\
\text { no sul de } \\
\text { Sydney na } \\
\text { Austrália }\end{array}$ & $\begin{array}{l}\text { - A área protegida apresenta } 87.500 \text { ha. } \\
\text { - O zoneamento foi realizado com a finalidade de } \\
\text { dispor a divisão da área para uma melhor gestão, } \\
\text { indicando os locais que demandavam maiores } \\
\text { cuidados, ou seja, as zonas prioritárias. } \\
\text { - A partir disso, foram estabelecidos os tipos e níveis } \\
\text { destas áreas que apresentam maior prioridade. } \\
\text { - O zoneamento auxiliou também na diminuição dos } \\
\text { conflitos e no uso e atividades presentes nas áreas } \\
\text { potencialmente conflitantes, de forma a proteger os } \\
\text { valores do parque. Este foi definido em cinco zonas, } \\
\text { sendo elas: Conservação e Recreação; Recreação e } \\
\text { Desenvolvimento; Região Selvagem; Área de } \\
\text { Referência; e Área de Educação (CNR, 1996). }\end{array}$ \\
\hline $\begin{array}{c}\text { Parque } \\
\text { Nacional de } \\
\text { Great Otway }\end{array}$ & $\begin{array}{l}\text { - O plano foi } \\
\text { elaborado em } \\
2009\end{array}$ & $\begin{array}{l}\text { Great } \\
\text { Otway na } \\
\text { Austrália }\end{array}$ & $\begin{array}{l}\text { - Apresenta uma área de } 103.185 \text { ha. } \\
\text { - Foi elaborado com o objetivo de proteger a área } \\
\text { assegurando as suas belezas naturais, além de } \\
\text { proporcionar oportunidades aos visitantes para } \\
\text { apreciar os seus recursos. } \\
\text { - o PM deste parque também apresenta a divisão da } \\
\text { área em zonas (área de referência, conservação, } \\
\text { conservação e recreação, proteção especial e uso } \\
\text { múltiplo) que facilitam a gestão da área. } \\
\text { - Outro ponto importante deste documento é o } \\
\text { resumo de atividades que são permitidas legalmente } \\
\text { pelo plano e as que não permitidas dentro das } \\
\text { limitações do parque, considerando a localidade de } \\
\text { cada zona específica (PARKS VICTORIA; DSE, } \\
\text { 2009). }\end{array}$ \\
\hline $\begin{array}{c}\text { Parque } \\
\text { Paneveggio - } \\
\text { Pale di San } \\
\text { Martino }\end{array}$ & $\begin{array}{l}\text { - O primeiro } \\
\text { plano for } \\
\text { elaborado em } \\
1996 \\
\\
\text { - Em fevereiro } \\
\text { de } 2016 \text { entrou } \\
\text { em vigor um } \\
\text { novo plano }\end{array}$ & $\begin{array}{l}\text { Paneveggio } \\
\text { - Pale di } \\
\text { San } \\
\text { Martino na } \\
\text { Itália }\end{array}$ & $\begin{array}{l}\text { - Apresenta uma área que corresponde um pouco } \\
\text { mais de } 19.700 \text { ha. } \\
\text { - O PM deste parque foi divido em três partes, a } \\
\text { primeira parte mostra o embasamento legal, na } \\
\text { segunda são apresentadas as características e os } \\
\text { aspectos metodológicos para a elaboração de } \\
\text { produtos que subsidiam a gestão da área e a terceira } \\
\text { parte contempla a avaliação do próprio plano. } \\
\text { - Dentre os produtos elaborados tem-se o } \\
\text { mapeamento de três zonas na qual o parque foi } \\
\text { dividido. A primeira zona corresponde às áreas de } \\
\text { preservação, as quais não podem ter nenhum tipo de } \\
\text { alteração e são submetidas a normas rígidas, já a } \\
\text { segunda compreende áreas que visam à preservação } \\
\text { ambiental, porém permitem o uso do solo, e a última } \\
\text { é embasada na conservação e desenvolvimento da } \\
\text { área, a partir de práticas turísticas e recreativas } \\
\text { (ZANON et al., 2016). }\end{array}$ \\
\hline
\end{tabular}


Tabela 8 - Informações sobre alguns planos de manejos de unidades de conservação nacionais e internacionais (continuação).

\begin{tabular}{|c|c|c|c|}
\hline Parques & $\begin{array}{c}\text { Ano do Plano } \\
\text { de Manejo }\end{array}$ & Local & Informações \\
\hline $\begin{array}{c}\text { Parque } \\
\text { Nacional } \\
\text { Tongariro }\end{array}$ & $\begin{array}{l}\text { O PM foi } \\
\text { elaborado em } \\
2006 \text { com uma } \\
\text { validade de dez } \\
\text { anos após a sua } \\
\text { elaboração }\end{array}$ & $\begin{array}{l}\text { Tongariro na } \\
\text { Nova Zelândia }\end{array}$ & $\begin{array}{l}\text { - O parque é considerado uma referência } \\
\text { internacional, devido a suas características } \\
\text { geográficas e também pela presença do vulcão } \\
\text { Plateau. } \\
\text { - Este foi dividido em sete partes, que inclui } \\
\text { dentre os tópicos o histórico da área, as suas } \\
\text { características físicas, o zoneamento do } \\
\text { parque, os objetivos e as questões legislativas } \\
\text { (MARSHALL et al., 2006). }\end{array}$ \\
\hline $\begin{array}{c}\text { Parque } \\
\text { Nacional } \\
\text { Narawntapu }\end{array}$ & $\begin{array}{lr}\text { Possui um } \\
\text { PM desde } \\
\text { ano de } 2000, \\
\text { sendo que } \\
\text { ano de } 2015 \text { foi } \\
\text { elaborado um } \\
\text { projeto } r \text { de } \\
\text { atualização } \\
\text { deste } \\
\text { documento }\end{array}$ & $\begin{array}{l}\text { Localizado no } \\
\text { centro-norte da } \\
\text { Tasmânia }\end{array}$ & $\begin{array}{l}\text { - Apresenta uma área de } 4.500 \text { ha. } \\
\text { - O projeto de atualização do plano apresentou } \\
\text { as características da área (como a } \\
\text { geodiversidade, fauna, flora, qualidade dos } \\
\text { recursos hídricos), bem como as propostas e } \\
\text { objetivos do manejo, além de apresentar um } \\
\text { tópico específico relacionado à recreação e as } \\
\text { práticas de turismo. } \\
\text { - Este último documento apresenta também o } \\
\text { mapeamento de três zonas (conservação, } \\
\text { recreação e serviços a visitantes) e seus } \\
\text { objetivos, conforme abaixo: } \\
\text { > Conservação: conservar a integridade natural } \\
\text { da área; proteger, manter e monitorar a } \\
\text { diversidade de espécies de plantas e animais; } \\
\text { conservar os valores patrimoniais; e manter a } \\
\text { qualidade cênica da área. } \\
\text { > Recreação: proteger, manter e monitorar o } \\
\text { patrimônio ambiental e suas características e } \\
\text { valores; e prever um baixo impacto permitindo } \\
\text { uso recreativo. } \\
\text { > Serviços a visitantes: proteger a área de } \\
\text { recreação; monitorar as atividades turísticas; e } \\
\text { disponibilizar infraestrutura adequada aos } \\
\text { turistas (PARKS; WILDLIFE SERVICE, } \\
\text { 2015). }\end{array}$ \\
\hline
\end{tabular}

\subsection{Bacia hidrográfica como unidade de planejamento}

A Bacia Hidrográfica $(\mathrm{BH})$ é considerada a região compreendida por um território e por vários cursos d'água. Da precipitação que abastece o interior da bacia, parte é responsável pelo escoamento superficial da água e a outra parte pelo processo de infiltração. A água presente na superfície escoa para os afluentes até chegar ao rio principal. Essas águas são descarregadas no ponto de altitude mais baixo da região, denominado de exutório (foz). Com relação à parte que infiltra no solo, uma parcela tende a escoar para os leitos dos rios, outra 
parte evapora por meio do processo de evapotranspiração, e a parcela restante é mantida no subsolo formando os aquíferos subterrâneos (ANA, 2011).

Segundo Christofoletti (1980), a BH é compreendida por um conjunto de cursos d'água, sendo que sua quantidade de água depende da sua área e dos processos naturais que a envolvem, como: precipitação, evaporação, infiltração, escoamento, entre outros.

Molle (2009) diz que a BH considerada como uma unidade de gestão e planejamento passou por diversas fases, desde seu início no século XVIII a BH foi inserida em vários contextos. No fim do século XIX, apoiava ideias de controle do regime hidrológico e da construção de barragens, principalmente na década de 30 até os anos 60. Logo, foi considerada importante para abordagens de problemas relacionados à qualidade da água. Em 1990, foi à peça fundamental para a gestão integrada dos recursos hídricos.

Para Nascimento e Villaça (2008), em várias regiões e países consolidou-se a BH como a unidade mais apropriada para a otimização de usos múltiplos, o gerenciamento e o desenvolvimento sustentável, devido à bacia possuir características que possibilita a integração de diferentes áreas e sistemas de planejamento e gestão, incluindo os estudos ambientais.

Segundo Cazula e Mirandola (2010) a BH como unidade territorial de planejamento possui aceitação mundial, sendo que esta é considerada do ponto de vista geográfico um sistema natural bem delimitado. Segundo os autores, estas unidades apresentam propriedades bem definidas, e com isso permitem a multidisciplinaridade entre vários sistemas de gestão.

No Brasil, a utilização da BH como unidade territorial se concretizou após a implementação da Política Nacional de Recursos Hídricos instituída pela Lei Federal $n^{\circ}$ 9.433/1997 com inciso $\mathrm{V}$, do artigo $1^{\circ}$, visto que a gestão ambiental é baseado no modelo francês.

A utilização do conceito de $\mathrm{BH}$ como uma unidade definida para estudo e gerenciamento, utilizada para a conservação dos recursos naturais, deve estar associada ao conceito do desenvolvimento sustentável, com o intuito de abranger três metas básicas, sendo elas: desenvolvimento econômico; a equidade social, econômica e ambiental; e por fim a sustentabilidade ambiental. Estes objetivos contemplam a integração entre o desenvolvimento socioeconômico em longo prazo e também a proteção ambiental, de forma a evidenciar a 
preocupação com a degradação ambiental e a capacidade de manter as funções ambientais dentro da BH (PIRES; SANTOS; DEL PRETTE, 2002).

Lorandi e Cançado (2002) também defendem que a sustentabilidade de um determinado sistema, considerando o cunho político, social, econômico e o ecológico, norteia pela exploração racional e gestão adequada dos recursos do meio natural, principalmente a gestão da BH. Dessa forma, o gerenciamento de uma determinada BH apresenta relação direta com o planejamento e uso dos seus recursos naturais, agregando com isso os processos e atividades antrópicas presentes.

Para Pessôa e Façanha (2016) a BH é considerada como o local onde se encontra as ações e degradações oriundas das atividades humanas. Segundo os autores, é com esta percepção que a bacia se destaca como unidade geossistêmica e também como unidade territorial de planejamento.

De acordo com Lorandi e Cançado (2002) os parâmetros físicos mais importantes relacionados ao gerenciamento de bacias hidrográficas que cada vez mais vem se expandindo pelo território brasileiro com o intuito de um sistema de melhor gestão, estão apresentados na Figura 5.

Figura 5 - Parâmetros físicos e o gerenciamento de bacias hidrográficas.

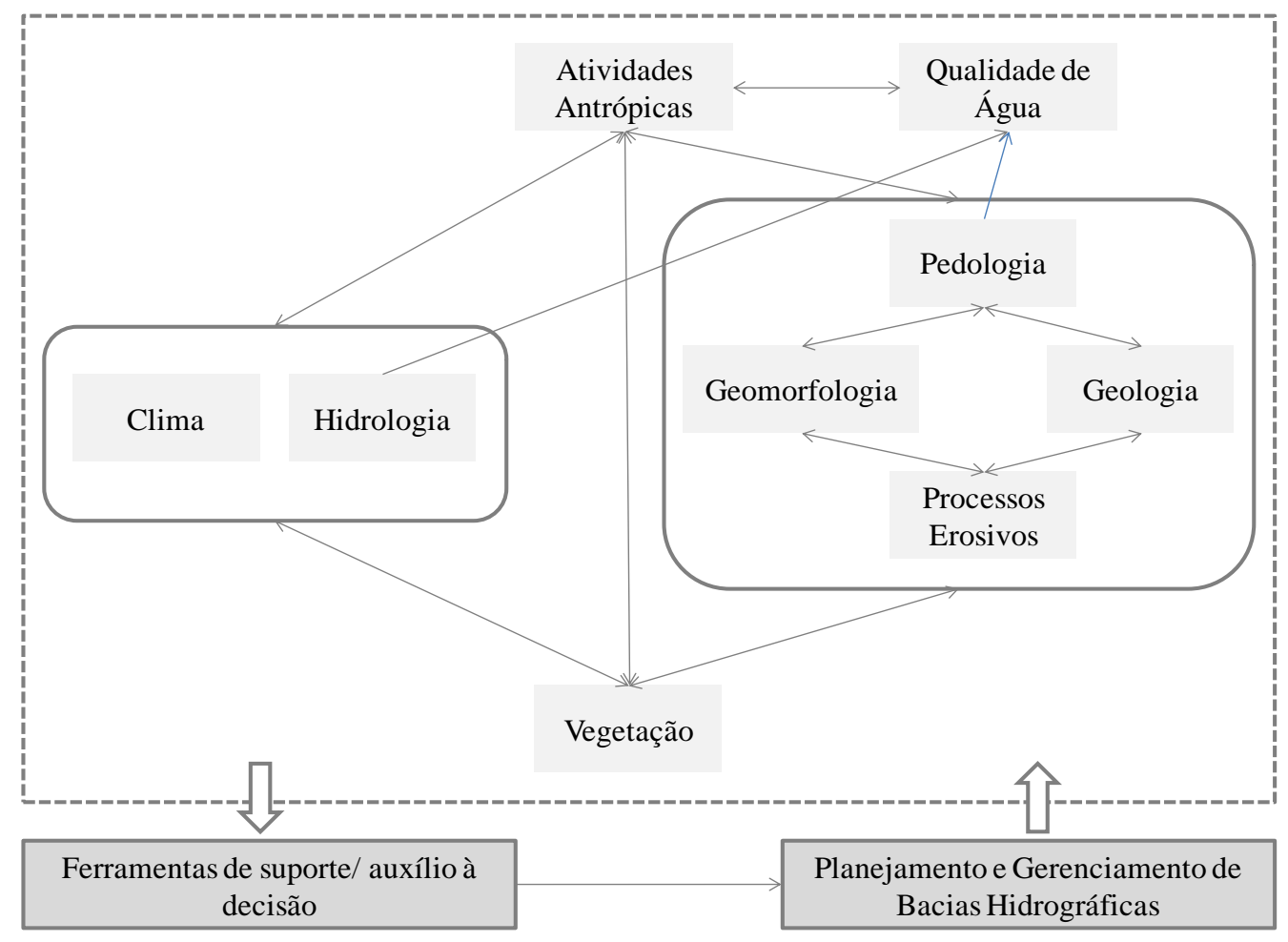

Fonte: Adaptado de Lorandi e Cançado (2002). 


\subsubsection{Caracterização morfométrica de bacias hidrográficas}

De acordo com Teodoro et al. (2007) a caracterização dos padrões morfométricos de uma bacia hidrográfica se destaca como uma das primeiras e mais comuns etapas realizadas em análises hidrológicas ou ambientais, e tem como finalidade esclarecer as diversas questões que relacionam com a dinâmica ambiental de um determinada região.

A associação de vários dados morfométricos possibilita a diferenciação de áreas homogêneas, dessa forma estes parâmetros podem apresentar indicadores físicos específicos para uma determinada área, permitindo a qualificação das alterações ambientais, além de serem importantes para identificar as vulnerabilidades ambientais em BHs (ANTONELI; THOMAZ, 2007).

Segundo Lana, Alves e Castro (2001) as diversas formas de relevo encontrado na superfície terrestre procedem da interação entre processos tectônicos, pedogênicos e intempéricos, que atuam de diferentes formas nos materiais rochosos. Para os autores, as BHs são consideradas como um sistema individualizado que fornecem dados relevantes para a aquisição de informações sobre a evolução do modelo da superfície da Terra.

O método da análise morfométrica é utilizado quando se deseja obter dados quantitativos para distinguir áreas homogêneas, visto que este método consiste na caracterização de parâmetros relacionados à morfologia, como: densidade hidrográfica, densidade de drenagem, gradiente de canais, índice de sinuosidade, entre outros (LANA, ALVES; CASTRO, 2001).

Segundo Sarma et al. (2013) a análise morfométrica de BH exerce grande relevância para compreender o seu comportamento geo-hidrológico, sendo importante na definição do tipo de clima, além da geologia, da geomorfologia, do controle estrutural, entre outros aspectos. Para Singh, Thakur e Singh (2013), este tipo de análise envolve realmente as observações do meio hidrogeológico, que integradas com a análise da rede de drenagem, proporcionam informações úteis sobre amplas relações sobre a estrutura geológica da bacia.

De acordo com Rather et al. (2017) a análise quantitativa de parâmetros de morfometria é de extrema utilidade na gestão de $\mathrm{BH}$, esta análise engloba a priorização da conservação do solo, da água, além da vegetação e do seu manejo. Para os autores, a 
morfometria desempenha um papel muito significativo na compreensão adequada dos processos de formação e propriedades físicas do solo.

Como diz Feltran Filho e Fátima de Lima (2007) as BHs enfrentam vários processos que acabam modificando a superfície terrestre. Estes autores também defendem que o estudo e a análise da superfície devem ir além do método qualitativo, por essa razão sugerem a utilização das características morfométricas na busca de informações para uma análise de cunho quantitativo, pois os valores poderão descrever o estado que se encontra a área em um determinado período da evolução da superfície.

Segundo Vestena, Checchia e Kobyiama (2011) as características morfométricas do padrão de drenagem e do relevo relacionam com algumas propriedades do terreno, como a capacidade de infiltração e deflúvio das águas das chuvas, além de refletir na litologia, estrutura geológica e formação da superfície terrestre. Estes autores também evidenciam que os aspectos morfométricos são utilizados para adquirir informações sobre a dinâmica da paisagem.

\subsubsection{1 Índices morfométricos}

Christofoletti (1980) uniu as variáveis morfométricas considerando três aspectos: análise areal, análise linear e análise hipsométrica, conforme a Tabela 9.

Tabela 9 - Variáveis morfométricas de acordo com os tipos de análise.

\begin{tabular}{c|l|l}
\hline \multicolumn{2}{c|}{ Análise } & \multicolumn{1}{c}{ Variáveis Morfométricas } \\
\hline \multirow{4}{*}{ Linear } & $\begin{array}{l}\text { Envolvem as medições realizadas ao } \\
\text { longo das linhas de escoamento }\end{array}$ & $\begin{array}{l}\text { - Razão de Bifurcação } \\
\text { - Razão entre comprimentos médios } \\
\text { - Comprimento do rio principal } \\
\text { - Extensão do percurso superficial }\end{array}$ \\
\hline \multirow{5}{*}{ Areal } & $\begin{array}{l}\mid c \\
\text { Abrangem as medições planimétricas } \\
\text { e lineares }\end{array}$ & $\begin{array}{l}\text { - Área } \\
\text { - Comprimento da bacia }\end{array}$ \\
& $\begin{array}{l}\text { - Forma da bacia } \\
\text { - Índice de circularidade } \\
\text { Hipsométrica }\end{array}$ & $\begin{array}{l}\text { - Densidade hidrográfica } \\
\text { - Densidade de drenagem }\end{array}$ \\
& $\begin{array}{l}\text { Referem-se às inter-relações } \\
\text { existentes entre unidades lineares e } \\
\text { planimétricas e suas relações com as } \\
\text { variáveis altimétricas }\end{array}$ & $\begin{array}{l}\text { - Amplitude máxima da bacia } \\
\text { - Relação de relevo }\end{array}$ \\
\hline
\end{tabular}


A seguir estão descritas algumas informações sobre nove parâmetros morfométricos utilizados neste trabalho.

\section{1-) Índice de Forma (K)}

Esta variável consiste na relação entre o perímetro da bacia e a sua área. Para este índice os valores que se aproximam da unidade, associam as bacias que tendem a apresentar uma forma circular. Este índice é calculado através da Equação 1 (GANDOLFI, 1971).

$$
\mathrm{K}=\mathrm{P} \times \frac{1}{2 \sqrt{\pi \times A}}
$$

Onde,

$\mathrm{P}=$ Perímetro da bacia

$\mathrm{A}=$ Área da bacia

\section{2-) Índice de Circularidade (Ic)}

O Ic representa a razão entre a área total da bacia e a área de um círculo de perímetro, visto que este deve ser igual ao da área total da bacia.

Miller (1953) ressalta que se o valor do índice for igual a um $(1,0)$ a bacia apresenta a forma circular e quando este valor se encontra no intervalo de 0,4 a 0,5 a bacia apresenta forma alongada e é composta por materiais geológicos homogêneos altamente permeáveis.

Quanto mais circular for à bacia maior também será a sua retenção de água, tornando mais susceptível à ocorrência de enchentes diminuindo os efeitos a jusante (BRUBACHER; OLIVEIRA; GUASSELLI, 2011). O índice é calculado a partir da Equação 2 (MILLER, 1953):

$$
\text { Ic }=\frac{\mathrm{A}}{\mathrm{Ac}}
$$

Onde,

$\mathrm{A}=$ Área da bacia

$\mathrm{Ac}=\mathrm{A}$ área do círculo cujo perímetro é igual ao da bacia 


\section{3-) Densidade de Drenagem (Dd)}

A definição desta variável se deu com Horton (1945) e mostra o grau de desenvolvimento da rede de drenagem de uma determinada bacia hidrográfica, dessa forma, correlaciona o comprimento total dos canais de drenagem com a área da bacia.

A Dd mostra o potencial de águas subterrâneas de uma determinada área, devido à sua relação com escoamento superficial e permeabilidade. Para Nag (1998) quando uma área apresenta baixa Dd o seu material do subsolo é permeável, a sua vegetação é densa e seu relevo é plano. No entanto, quando a área apresenta alta Dd o material que a constitui é impermeável, além da vegetação ser esparsa e apresentar relevo montanhoso.

Segundo Moura (2013) quando o índice apresentar valores altos, menor será a capacidade de infiltração de água, caso contrário indica que a área é mais favorável a esse processo, contribuindo com o abastecimento do lençol freático. A Dd é calculada pela Equação 3 (HORTON, 1945):

$$
\mathrm{Dd}=\frac{\sum \mathrm{L}}{\mathrm{A}}
$$

Onde,

$\sum \mathrm{L}=$ Comprimento total dos canais de drenagem

$\mathrm{A}=$ Área da bacia

\section{4-) Densidade Hidrográfica (Dh)}

Segundo Christofoletti (1980), a Dh corresponde à relação existente entre o número de rios ou canais e a área da bacia hidrográfica. O cálculo da Dh é importante para representar o comportamento hidrográfico da bacia, principalmente relacionado a um de seus aspectos básicos: a aptidão de gerar novos canais de drenagem. O índice é calculado pela Equação 4 (HORTON, 1945):

$$
\mathrm{Dh}=\frac{\mathrm{n}}{\mathrm{A}}
$$


Onde,

$\mathrm{n}=$ Número de canais de drenagem de $1^{\mathrm{a}}$ ordem

$\mathrm{A}=$ Área da bacia

\section{5-) Textura Topográfica (Tt)}

Este parâmetro apresenta o grau de dissecação ou entalhamento de uma superfície do terreno. Para Soni (2016) a Tt está relacionada com a Dd e a frequência dos canais, e sofre influência de diversos atributos como o clima, vegetação, litologia, tipo de solo, capacidade de infiltração.

Nag (1998) conclui que quanto maior for o espaçamento entre os cursos d'água, a textura é considerada grosseira, caso contrário é denominada de fina. Este índice é obtido através da Equação 5 (SMITH, 1950 apud FRANÇA, 1968):

$$
\log \mathrm{Tt}=0,219649+1,115 \log \mathrm{Dd}
$$

Onde,

Dd $=$ Densidade de drenagem

\section{6-) Coeficiente de Manutenção (Cm)}

Shumm (1956) relata que este índice expressa à área mínima para manutenção de um metro de canal com escoamento permanente.

As bacias hidrográficas que apresentam valores mais elevados deste parâmetro possuem valores mais baixos de Dd. Este índice é calculado pela Equação 6 (SHUMM, 1956):

$$
\mathrm{Cm}=\frac{1}{\mathrm{Dd}} \times 1000
$$

Onde,

Dd $=$ Densidade de drenagem 


\section{7-) Relação de Relevo (Rr)}

Foi inicialmente apresentada por Schumm (1956), e está relacionada às variações topográficas de uma BH. Segundo Javed, Khanday e Ahmed (2009) este índice apresenta a inclinação geral de uma bacia e serve como um indicador da intensidade dos processos erosivos existentes na sua área.

Está variável relaciona a amplitude altimétrica máxima com o seu maior comprimento, evidenciando que quanto mais elevado for o valor de $\mathrm{Rr}$, maior será o desnível entre a cabeceira e foz. A Rr pode ser definida pela Equação 7 (SCHUMM, 1956):

$$
\mathrm{Rr}=\frac{\mathrm{Hm}}{\mathrm{Lb}}
$$

Onde,

$\mathrm{Hm}$ = Diferença máxima de altitude entre a desembocadura e o ponto mais alto do divisor de águas

$\mathrm{Lb}=$ Maior comprimento linear medido paralelamente ao curso principal

\section{8-) Índice de Rugosidade (Ir)}

Este índice mostra a relação da disponibilidade do escoamento hídrico superficial com seu potencial erosivo, expresso pela declividade média. Sendo que, quanto maior for o valor do índice, maior também será o risco de processo de degradação na bacia quando as vertentes apresentarem declividades mais altas e comprimentos longos (TRAJANO et al., 2012).

Consiste-se em um índice adimensional e é calculado pela Equação 8 (MELTON, 1957 apud CHRISTOFOLETTI, 1980):

$$
\mathrm{Ir}=\mathrm{H} \times \mathrm{Dd}
$$

Onde,

$\mathrm{H}=$ Amplitude altimétrica

Dd $=$ Densidade de drenagem 


\section{9-) Extensão do percurso superficial (Eps)}

Esta variável mede a distância média percorrida por um fluxo hídrico até o canal permanente. O Eps é obtido pelo cálculo da Equação 9 (CHRISTOFOLETTI, 1980):

$$
\text { Eps }=\frac{1}{2 \mathrm{Dd}}
$$

Onde,

Dd $=$ Densidade de drenagem

Diversos são os estudos no mundo que utilizam índices morfométricos, a Tabela 10 apresenta alguns trabalhos que envolveram a caracterização morfométrica de BHs para diferentes fins.

Tabela 10 - Estudos realizados com o uso de índices morfométricos.

\begin{tabular}{c|c|l}
\hline Autores /Ano & Local & \multicolumn{1}{c}{ Objetivo } \\
\hline $\begin{array}{c}\text { Santos e } \\
\text { Sobreira / 2008 }\end{array}$ & $\begin{array}{c}\text { Bacias do Córrego Carioca, } \\
\text { Córrego do Bação e Ribeirão } \\
\text { Carioca na região do Alto Rio } \\
\text { das Velhas (MG) }\end{array}$ & $\begin{array}{l}\text { Auxiliar na percepção da vulnerabilidade natural } \\
\text { dos terrenos às atividades humanas e aos } \\
\text { processos erosivos, além da definição do } \\
\text { zoneamento territorial para a compreensão da } \\
\text { dinâmica superficial da área }\end{array}$ \\
\hline $\begin{array}{c}\text { Chen e Yu / } \\
2011\end{array}$ & $\begin{array}{c}\text { 11 Bacias Hidrográficas na } \\
\text { região central e norte de } \\
\text { Taiwan }\end{array}$ & $\begin{array}{l}\text { Identificar características topográficas para a } \\
\text { ocorrência de corrida de detritos, tomando como } \\
\text { base as análises geomorfológicas }\end{array}$ \\
\hline $\begin{array}{c}\text { Angillieri / } \\
2012\end{array}$ & $\begin{array}{c}\text { Bacia Hidrográfica do Rio } \\
\text { Carrizal (Argentina) }\end{array}$ & $\begin{array}{l}\text { Prognosticar o comportamento da bacia durante } \\
\text { chuvas intensas e calcular o risco de inundaçães }\end{array}$ \\
\hline $\begin{array}{c}\text { Silva Neto et al. } \\
\text { / 2013 }\end{array}$ & $\begin{array}{c}\text { Bacia Hidrográfica do Rio } \\
\text { Gramame (PB) }\end{array}$ & $\begin{array}{l}\text { Adquirir as características morfométricas através } \\
\text { do uso de algoritmos agregados às tecnologias } \\
\text { de geoprocessamento, fazendo uso de imagens } \\
\text { SRTM }\end{array}$ \\
\hline $\begin{array}{c}\text { Devi e } \\
\text { Goswami / } \\
2015\end{array}$ & $\begin{array}{c}\text { Bacia Hidrográfica do Rio } \\
\text { Subansiri (Índia) }\end{array}$ & $\begin{array}{l}\text { Para a compreensão do cenário de perigo a } \\
\text { eventos de inundação }\end{array}$ \\
\hline $\begin{array}{c}\text { Ibrahim, Hajj e } \\
\text { Hage / 2015 }\end{array}$ & $\begin{array}{c}\text { Bacia Hidrográfica do Rio } \\
\text { Arqa (Líbano) }\end{array}$ & $\begin{array}{l}\text { Caracterizar a bacia para posteriormente realizar } \\
\text { o mapeamento de processos de erosão e estimar } \\
\text { a capacidade de infiltração, além de monitorar o } \\
\text { fluxo de água superficial }\end{array}$ \\
\hline
\end{tabular}


Tabela 10 - Estudos realizados com o uso de índices morfométricos (continuação).

\begin{tabular}{|c|c|c|}
\hline Autores /Ano & Local & Objetivo \\
\hline Biswas / 2016 & $\begin{array}{c}\text { Bacia Hidrográfica do Rio } \\
\text { Parbati (Índia) }\end{array}$ & $\begin{array}{l}\text { Avaliar os aspectos morfométricos } \\
\text { descobrir as recentes } \\
\text { hidrográfica }\end{array}$ \\
\hline $\begin{array}{l}\text { Akinwumiju e } \\
\text { Olorunfemi / } \\
2016\end{array}$ & $\begin{array}{c}\text { Bacia Hidrográfica do Rio } \\
\text { Osun (Nigéria) }\end{array}$ & $\begin{array}{l}\text { Analisar os parâmetros morfométricos para a } \\
\text { avaliação das características geomorfométricas, } \\
\text { e identificar o potencial de infiltração da bacia }\end{array}$ \\
\hline $\begin{array}{l}\text { Richardson et } \\
\text { al. / } 2016\end{array}$ & $\begin{array}{l}\text { Bacia Hidrográfica do Rio } \\
\text { Gouritz } \\
\text { (África do Sul) }\end{array}$ & $\begin{array}{l}\text { Verificar se os índices morfométricos podem } \\
\text { proporcionar uma visão mais detalhada da } \\
\text { história das paisagens antigas pouco estudadas } \\
\text { na região sul da África do Sul }\end{array}$ \\
\hline $\begin{array}{l}\text { Abboud e Nofal } \\
\text { / } 2017\end{array}$ & $\begin{array}{l}\text { Bacia Hidrográfica do Rio } \\
\text { Khumal } \\
\text { (Arábia Saudita) }\end{array}$ & $\begin{array}{l}\text { Utilizar os parâmetros morfométricos e as } \\
\text { características de fluxo da bacia para gestão dos } \\
\text { recursos hídricos, para a caracterização } \\
\text { geomorfológica, em especial favorecendo a } \\
\text { análise dos padrões de drenagem e dos cenários } \\
\text { geológicos da bacia }\end{array}$ \\
\hline
\end{tabular}

\subsection{Análise de agrupamentos}

Análise de Agrupamentos (AA) também conhecida como Cluster Analysis é utilizada para descrever inúmeras técnicas numéricas, com a finalidade de classificar os valores de uma matriz de dados em grupos discretos. A técnica de classificação multivariada é comumente empregada quando se deseja explorar o nível de similaridade entre indivíduos (modo Q) ou entre variáveis (modo R) (LANDIM, 2011).

De acordo com Hair et al. (2009) a AA se diferencia da análise discriminante, devido os grupos não serem pré-definidos, dessa forma a técnica é empregada para a identificação de grupos.

AA em geral abrange no mínimo três etapas, sendo elas:

- a medida de similaridade ou associação entre as entidades para definir quantos grupos existem na amostra.

- o processo de agrupamento, o qual as entidades são divididas em grupos (agrupamentos). 
- o esclarecimento do perfil das variáveis para determinar sua composição, em muitos casos isso é possível pela aplicação da análise discriminante aos grupos identificados após a técnica de agrupamento (HAIR et al., 2009).

De acordo com Pereira (1993) a aplicação das técnicas de agrupamentos envolve também três passos. O primeiro passo consiste tanto na escolha das variáveis mais apropriadas para a caracterização dos objetos, além da coleta dos dados, as questões para padronizar ou ponderar as variáveis e a escolha da medida que melhor represente as diferenças entre os objetos. O segundo passo contempla a escolha do método de agrupamento a ser empregado. O terceiro passo abrange em determinar, baseado na hierarquia, o número de grupos mais adequado.

Halkidi, Batistakis e Vazirgiannis (2001) definem as fases básicas da AA conforme apresentadas na Figura 6.

Figura 6- Fases de uma análise de agrupamentos.

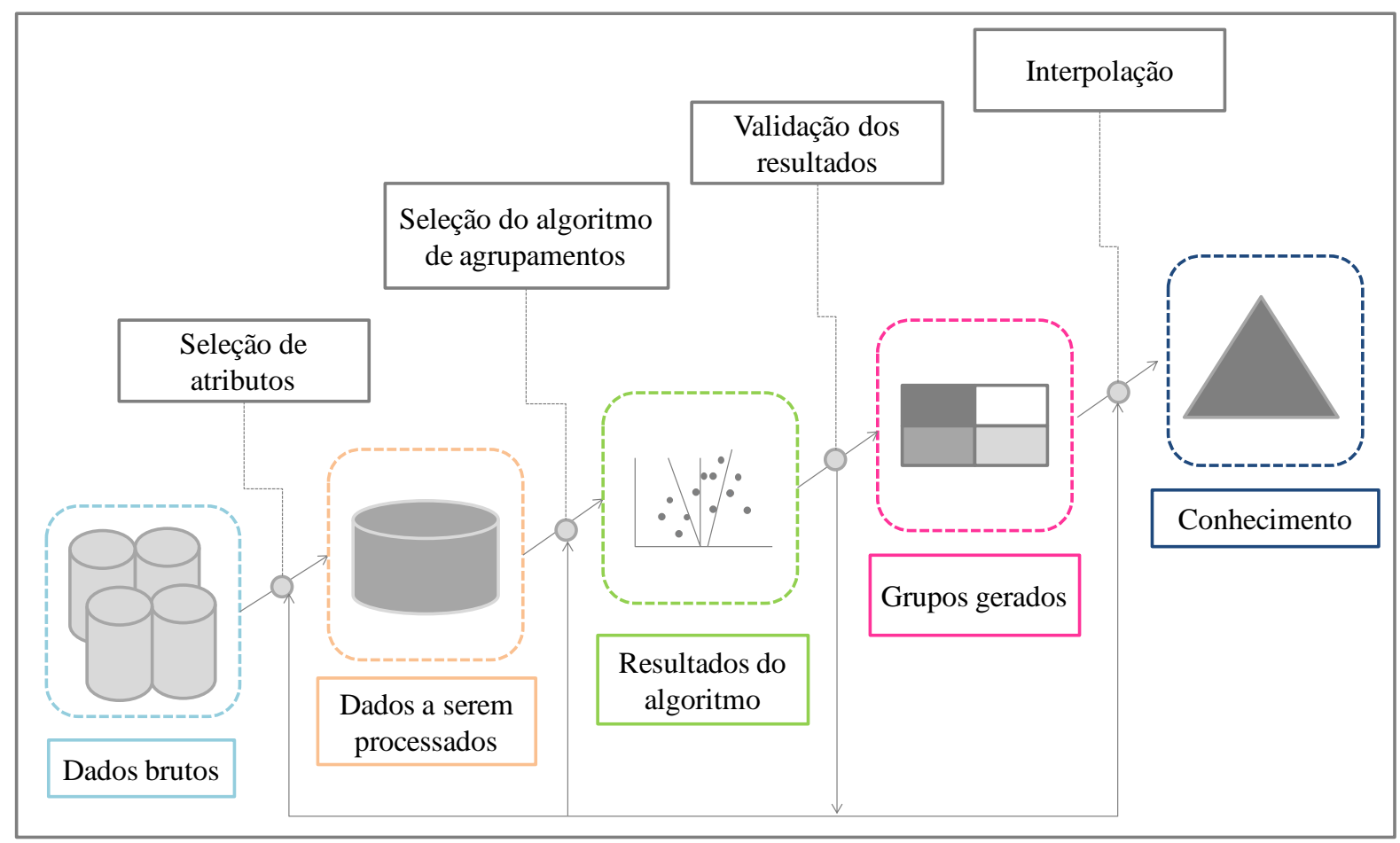

Fonte: Adaptado de Halkidi, Batistakis e Vazirgiannis (2001).

Os métodos para a AA são separados em quatro tipos, sendo eles: método de partição; método com origem arbitrária; método por similaridade mútua; e métodos hierárquicos (DAVIS; 1986). Segundo Pereira (1993) há uma maior utilização das técnicas hierárquicas, pelo motivo de serem mais simples e versáteis, além da disponibilidade de métodos. 
Com relação às técnicas de agrupamentos hierárquicos, Landim (2011) ressalta que existem diversos métodos, e cita os cinco mais utilizados: ligação simples (single linkage method - nearest neighbor); ligação completa (complete linkage method - farthest neighbor); agrupamento pareado proporcionalmente ponderado (weighted pair-group method - WPGM); agrupamento pareado igualmente ponderado (unweighted pair-group method - UPGM); variância mínima (minimum variance clustering - Ward's method of sum-of-squares method).

Dentre as técnicas citadas, o autor recomenda o agrupamento pareado igualmente ponderado. Esta técnica baseia-se em localizar os pares de objetos com menor coeficiente de distância ou com maior coeficiente de correlação (ambos são critérios de similaridade utilizados para agrupar os dados). Logo, através da aplicação da média aritmética simples são apresentados valores médios que posteriormente resultarão em uma nova matriz de similaridade.

Dentre os coeficientes que podem ser utilizados, o agrupamento dos dados apresenta melhores resultados com a utilização do coeficiente de distância, sendo a euclidiana a medida mais empregada (LANDIM, 2011).

A forma gráfica mais comum de apresentar a hierarquia dos grupos (clusters) formados são os dendrogramas, estes apresentam linhas que mostram a união dos pares de casos com relação às variáveis analisadas.

A análise de agrupamentos pode ser realizada em diferentes estudos, dentre estes, os que envolvem diversos parâmetros do meio físico, como Collares (2000) que avaliou as mudanças das microbacias do Rio Capivari (SP), através da análise de variáveis morfológicas, a qual permitiu o agrupamento das microbacias com relação ao seu grau de alteração.

Amorim (2003) também utilizou o processo estatístico de análise de agrupamentos de variáveis geomorfológicas, geológicas, pedológicas e de aptidão agrícola, para definir as unidades geoambientais da região de influência do reservatório da usina hidroelétrica de Caconde situada no estado de São Paulo.

Pinto et al. (2016) também utilizou a técnica de agrupamentos, mais especificamente a "K-means e Fuzzy C-means". Os autores tiveram como objetivo estudar a suscetibilidade à inundação da bacia hidrográfica do Ribeirão do Espírito Santo (MG), para isso utilizou a caracterização morfométrica, fazendo uso de duas, três e cinco classes de vulnerabilidade. No estudo foi observado que o número de classes de vulnerabilidade influencia a classificação 
das áreas em que foi dividida a bacia hidrográfica, por isso os autores sugeriram a validação de cluster para balizar a escolha do número de classes.

\section{4 Índices de degradação ambiental}

Antes de apresentar alguns índices de degradação, é necessária a compreensão do significado de degradação ambiental, visto que este termo é confundido com os conceitos de impacto ambiental e poluição.

Sendo assim, o conceito de degradação ambiental é considerado um termo de conotação negativa. $\mathrm{O}$ emprego do termo na literatura ambiental científica está geralmente ligado a uma alteração artificial ou perturbação oriunda de atividades humanas. De maneira geral é compreendida como uma redução das condições do meio natural ou do estado de um ambiente (JOHNSON et al., 1977 apud SÁNCHEZ, 2013). Segundo o mesmo autor, o agente que causa o processo de degradação ambiental é sempre o ser humano, pois os processos naturais não degradam os ambientes, somente causam alterações.

A Lei Federal nº 6.938 de 1981 que institui a Política Nacional do Meio Ambiente (PNMA) apresenta no seu artigo $3^{\circ}$ (inciso III), que a degradação ambiental é "a alteração adversa das características do meio ambiente”, que de acordo com Sánchez (2013) o conceito descrito na lei é bastante amplo para envolver todos os casos de prejuízo à saúde, a segurança, o bem-estar das populações, as atividades socioeconômicas, a biosfera e as condições estéticas ou sanitárias do meio, sendo empregada pela lei ao conceito de poluição.

Sánchez (2013) diz que a degradação ambiental pode ser entendida como qualquer alteração dos processos, funções ou elementos ambientais, ou como uma mudança adversa da qualidade ambiental.

Diversas são as práticas humanas que causam alterações negativas em uma determinada região, para classificar uma área quanto ao seu nível de degradação foram elaborados índices que tem a capacidade de mensurar a pressão antrópica que se encontra uma área.

A Tabela 11 apresenta algumas informações sobre alguns índices relacionados à degradação ambiental. 
Tabela 11 - Informações sobre alguns índices relacionados à degradação ambiental.

\begin{tabular}{|c|c|c|}
\hline $\begin{array}{c}\text { Autores/ } \\
\text { Ano }\end{array}$ & Informações & Equação e Variáveis \\
\hline $\begin{array}{l}\text { Mateo / } 1984 \\
\text { apud Rocha e } \\
\text { Cruz / } 2009\end{array}$ & $\begin{array}{l}\text { O objtivo da elaboração do índice foi } \\
\text { quantificar a pressão antrópica sobre um } \\
\text { elemento do meio ambiente. Envolve a } \\
\text { ponderação dos tipos de uso e ocupação do } \\
\text { solo em uma determinada área }\end{array}$ & $\begin{array}{l}\quad I T A=\frac{\sum(\% \text { do uso do solo } \times \text { Peso })}{100} \\
\text { ITA = Índice de transformação antrópica } \\
\text { Uso = área em percentual da classe de uso } \\
\text { e cobertura } \\
\text { Peso }=\text { varia de } 1 \text { até } 10\end{array}$ \\
\hline $\begin{array}{c}\text { Jha e Murthy / } \\
2003\end{array}$ & $\begin{array}{l}\text { - Aplicado em } 174 \text { países } \\
\text { - Para o desenvolvimento do índice de } \\
\text { degradação ambiental (IDA) foi utilizado a } \\
\text { análise de componentes principais, a qual } \\
\text { foi relacionada com o índice de } \\
\text { desenvolvimento humano (IDH) levando } \\
\text { em consideração dessa forma o setor } \\
\text { econômico. O índice foi calculado para } 174 \\
\text { países }\end{array}$ & $\begin{array}{l}\qquad \mathrm{IDA}=\sum_{\mathrm{j}} \mathrm{W}_{\mathrm{j}} \mathrm{X}_{\mathrm{ji}} \\
\text { IDA = Índice de degradação ambiental } \\
\mathrm{W}_{\mathrm{j}}=\text { pontuação do j-ésimo componente } \\
\mathrm{X}_{\mathrm{ji}}=\text { valor da j-ésima variável para o i- } \\
\text { ésimo país dado } \\
\mathrm{J}=1,3,4 \text { e } 5\end{array}$ \\
\hline Brandão / 2005 & $\begin{array}{l}\text { - Aplicado na Bacia Hidrográfica do } \\
\text { Ribeirão do Peixe (PB) } \\
\text { - Foi elaborado por meio dos conceitos de } \\
\text { Ecodinâmica, já desenvolvido por Tricart } \\
\text { (1977), e dos métodos de classificação } \\
\text { ambiental elaborados por Ross (1994), além } \\
\text { do método proposto pelo Instituto Nacional } \\
\text { de Pesquisa Espacial (INPE) - denominado } \\
\text { de "Modelo de Fragilidade Potencial } \\
\text { Natural com apoio em Unidades Territoriais } \\
\text { Básicas". Este índice varia de } 0 \text { a } 1\end{array}$ & $\begin{array}{l}\quad \text { IDA }=\frac{\left[1-\left(\frac{V+S}{2}\right)\right]+\left(\frac{D+P}{2}\right)}{2} \\
\text { IDA= Índice de degradação ambiental } \\
\mathrm{V}=\text { vegetação (percentual de cobertura } \\
\text { vegetal); } \\
\mathrm{S}=\text { Característica do horizonte A do solo; } \\
\mathrm{D}=\text { Declividade } \\
\mathrm{P}=\text { Pressão Antrópica (Densidade } \\
\text { Demográfica) }\end{array}$ \\
\hline $\begin{array}{c}\text { Kazmierczak e } \\
\text { Seabra / } 2007\end{array}$ & $\begin{array}{l}\text { - Aplicado na Região de São Carlos (SP) no } \\
\text { Compartimento Geomorfológico do } \\
\text { Planalto Ocidental Paulista } \\
\text { - Utilizou-se } 5 \text { indicadores para fornecer } \\
\text { estimativas quantitativas dos efeitos dos } \\
\text { vários fatores que atuam sobre o } \\
\text { ambiente.Cada indicador adota valores entre } \\
1 \text { a 5, em função das classes de } \\
\text { susceptibilidade estabelecidas. O índice } \\
\text { calcula o grau de suscetibilidade à } \\
\text { degradação, que pode variar de } 4 \text { a } 25\end{array}$ & $\begin{array}{l}\text { ISDA = USO + NDVI + PPT + PEP + ERO } \\
\text { ISDA = Índice suscetibilidade à } \\
\text { degradação ambiental } \\
\text { USO = Uso do solo } \\
\text { NDVI= Índice de vegetação diferença } \\
\text { normalizada, } \\
\text { PPT = Precipitação, } \\
\text { PEP = Pressão exercida pela pecuária } \\
\text { ERO = Potencial de erodibilidade }\end{array}$ \\
\hline
\end{tabular}


Tabela 11 - Informações sobre alguns índices relacionados à degradação ambiental (continuação).

\begin{tabular}{|c|c|c|}
\hline $\begin{array}{c}\text { Autores/ } \\
\text { Ano }\end{array}$ & Informações & Equação e Variáveis \\
\hline $\begin{array}{l}\text { Ferreira et al. / } \\
2008\end{array}$ & $\begin{array}{l}\text { - Aplicado em áreas mineradas no } \\
\text { município de Caraguatatuba (SP) } \\
\text { - Foram considerados quatro indicadores } \\
\text { que colaboram de modo e intensidade } \\
\text { diferente para a quantificação da } \\
\text { degradação. Logo foi atribuído pesos para } \\
\text { os indicadores considerando a técnica } \\
\text { AHP (Processo Analítico Hierárquico) }\end{array}$ & $\begin{array}{l}\mathrm{IDeg}=\text { Peso } \times \mathrm{PE}_{\mathrm{n}}+\text { Peso x } \mathrm{IT}_{\mathrm{n}}+\text { Peso x } \\
\mathrm{SE}_{\mathrm{n}}+\text { Peso } \mathrm{x} \mathrm{VH}_{\mathrm{n}} \\
\mathrm{IDeg} \text { Índice de degradação ambiental } \\
\mathrm{PE}_{\mathrm{n}}=\text { valor do indicador processos erosivos } \\
\text { normalizado } \\
\mathrm{IT}_{\mathrm{n}}=\text { valor do indicador irregularidade do } \\
\text { terreno normalizado } \\
\mathrm{SE}_{\mathrm{n}}=\text { valor do indicador solo exposto } \\
\text { normalizado } \\
\text { VH } \\
\text { herbácea-arbustiva normalizado }\end{array}$ \\
\hline $\begin{array}{l}\text { Gonçalves } \\
\text { Junior e } \\
\text { Rodrigues / } \\
2013\end{array}$ & $\begin{array}{l}\text { - Aplicado nos municípios do Estado do } \\
\text { Paraná } \\
\text { - Para a elaboração do índice foram } \\
\text { selecionadas as seguintes variáveis: } \\
\text { número de licenças ambientais ativas } \\
\text { /número de habitantes; grau de } \\
\text { urbanização; densidade demográfica; frota } \\
\text { de veículos/número de habitantes; } \\
\text { habitantes/atendimentos de esgoto e o } \\
\text { consumo de água/habitantes. Foi } \\
\text { considerado que quanto maior o valor das } \\
\text { variáveis analisadas, maior a degradação } \\
\text { ambiental. Em seguida buscou-se por meio } \\
\text { da análise fatorial multivariada a redução } \\
\text { das dimensões das variáveis em fatores, } \\
\text { além da estimação das cargas fatoriais }\end{array}$ & $\begin{array}{l}\mathrm{B}=\text { Índice de degradação ambiental bruto } \\
\mathrm{W}_{\mathrm{i}}=\text { a proporção da variância explicada por } \\
\text { cada fator } \\
\mathrm{F}_{\mathrm{i}}=\text { os escores fatoriais }\end{array}$ \\
\hline $\begin{array}{l}\text { Pinto; Lopes e } \\
\text { Coronel / } 2014\end{array}$ & $\begin{array}{l}\text { - Aplicado nos municípios e mesorregiões } \\
\text { do Estado do Paraná } \\
\text { - Foi utilizada a técnica de análise fatorial } \\
\text { através do método de componentes } \\
\text { principais, a qual foi aplicada ao grupo de } \\
\text { variáveis do estudo para mensurar a } \\
\text { magnitude do processo de degradação. Os } \\
\text { escores fatoriais obtidos por meio dessa } \\
\text { técnica possibilitou a construção do índice } \\
\text { de degradação }\end{array}$ & $\begin{array}{l}\qquad I d i=\sum_{j=1}^{p} \frac{\lambda_{j}}{\sum \lambda_{j}} F_{j i}^{*} \\
\mathrm{IDi}=\text { Índice de Degradação do i-ésimo } \\
\text { município analisado } \\
\mathrm{J}=\text { refere-se à j-ésima raiz característica } \\
\mathrm{P}=\text { número de fatores extraídos na análise } \\
\mathrm{F}_{\mathrm{ji}}{ }^{*}=\text { é o j-ésimo escore fatorial do i-ésimo } \\
\text { município analisado } \\
\sum \lambda_{\mathrm{j}}=\text { o somatório das raízes características } \\
\text { referentes aos p fatores extraídos }\end{array}$ \\
\hline
\end{tabular}




\subsection{Ferramentas auxiliares no estudo geoambiental}

Com o avanço crescente das tecnologias, as ferramentas estão cada vez mais dispondo de capacidades inovadoras, isso comprova o aumento da sua utilização em diferentes estudos, que demandam de eficiência e qualidade nos produtos elaborados. Os itens a seguir, englobam as ferramentas e técnicas utilizadas neste trabalho.

\subsubsection{Geoprocessamento}

Um dos instrumentos que viabiliza o planejamento é o desenvolvimento de técnicas de criação e análise dos dados espaciais, ou melhor, a utilização das técnicas de geoprocessamento (FARINA, 2006).

Para Silva e Machado (2012) nos últimos anos os avanços na ciência e tecnologia foram importantes na evolução da cartografia, nos estudos e análises relacionados à representação e a dinâmica da superfície terrestre, bem como em outros estudos geográficos. A partir de então, originou-se o geoprocessamento, como um conceito inovador de técnicas e métodos diferenciados para a representação espacial de um terreno em ambiente computacional, proporcionando maior rapidez e eficiência na elaboração de documentos cartográficos, fazendo com que esta atividade seja cada vez mais automatizada e multidisciplinar. Frente a essas considerações, a relação entre a ciência da geomorfologia e as técnicas do geoprocessamento colabora com o desenvolvimento das análises integradas e as tomadas de decisão através da aquisição, preparo e análise das informações geográficas.

De acordo com Silva (2000), o geoprocessamento é visto como um grupo de métodos computacionais que atua sobre as bases de dados georreferenciados, com a intenção de transformar estes dados em informações de grande relevância, tendo como aporte as estruturas de percepção do meio ambiente. Como exemplo, uma destas estruturas é a visão sistêmica, na qual a informação pode ser validada, através do uso de diferentes tipos de sistemas de identificação, que se organizam por meio de vários tipos de relacionamento, entre os quais podem ser utilizados para as investigações ambientais, as relações de inserção (hierarquia), justaposição (proximidade /contiguidade) e funcionalidade (causalidade).

Conforme Oliveira, Soares e Nishiyama (2011) o sistema de geoprocessamento é utilizado no processamento de dados georreferenciados, desde a fase de coleta (etapa inicial) 
até os dados de saída (etapa final) em formato de mapas convencionais, arquivos digitais, entre outros. Para os autores, com o progresso das geotecnologias é possível avaliar uma determinada área por processos naturais ou antrópicos. Esse procedimento acontece devido à união do conjunto de dados e a visualização destes em meio digital. Desse modo, permite avaliar, analisar e estabelecer soluções que melhorem as condições do ambiente.

De acordo com Hoff, Leite e Zouain (2010), em grande parte, as ações humanas mantêm um forte vínculo com as superfícies dos terrenos, e o comportamento dessas superfícies está diretamente relacionado com a geologia, geomorfologia, as condições de cobertura do solo e o clima, que são característicos em cada uma das regiões. Portanto, conhecer o relevo e o subsolo de uma dada região proporciona uma melhor vistoria dos impactos ambientais. $\mathrm{O}$ uso de geotecnologias favorece o estudo de uma área, tornando-o mais abrangente e possibilitando que os processamentos das informações sejam efetuados com maior rapidez, para isto são utilizadas ferramentas como Sensoriamento Remoto (SR) e os Sistemas de Informações Geográficas (SIG), que adaptam e aprimoram os levantamentos na área das geociências. O SR e o SIG vêm sendo bastante usados em estudos em escala municipal, auxiliando nas tomada de decisões do setor de planejamento frente às demandas impostas pela área.

Leite (2013) diz que, com o avanço das geotecnologias, cada vez mais são utilizadas técnicas de SR e SIG para fins da elaboração de estudos ambientais. Com relação às técnicas de SR, elas proporcionam uma visão sinótica do espaço territorial, e os resultados podem ser obtidos em um curto intervalo de tempo. Estas técnicas são importantes por causa de suas finalidades, dentre elas citam-se: a obtenção de dados através de sistemas orbitais e levantamentos aéreos; e a elaboração e análise dos produtos com base no comportamento espectral dos alvos que encobrem a superfície terrestre.

Câmara e Medeiros (1998) defendem a importância do mapeamento das áreas considerando a aplicação do geoprocessamento com relação aos tipos de dados utilizados (Tabela 12). 
Tabela 12 - Aplicações típicas de geoprocessamento.

\begin{tabular}{|c|c|c|c|c|}
\hline Aplicações & $\begin{array}{l}\text { Escalas } \\
\text { Típicas }\end{array}$ & $\begin{array}{l}\text { Tipos de } \\
\text { Dados }\end{array}$ & $\begin{array}{c}\text { Representações } \\
\text { Gráficas }\end{array}$ & Operações \\
\hline Floresta & $\begin{array}{l}1: 10.000 \mathrm{a} \\
1: 1.000 .000\end{array}$ & $\begin{array}{l}\text { Dados } \\
\text { temáticos, } \\
\text { Imagens }\end{array}$ & $\begin{array}{l}\text { Matricial, } \\
\text { Vetorial }\end{array}$ & $\begin{array}{ll}\text { - } & \text { Classificação } \\
\text { imagens } \\
\text { - } & \text { Consulta } \\
\text { espacial }\end{array}$ \\
\hline Agricultura & $\begin{array}{l}1: 5.000 \mathrm{a} \\
1: 250.000\end{array}$ & $\begin{array}{c}\text { Dados } \\
\text { temáticos, } \\
\text { Imagens, } \\
\text { MNT*, } \\
\text { Cadastro Rural }\end{array}$ & $\begin{array}{c}\text { Matricial, } \\
\text { Vetorial, Grades, } \\
\text { TIN }\end{array}$ & $\begin{array}{ll}\text { - } & \text { Análise espacial } \\
\text { - } & \text { Declividade } \\
\text { - } & \text { Consulta } \\
& \text { espacial }\end{array}$ \\
\hline $\begin{array}{c}\text { Geologia- } \\
\text { Geomorfologia }\end{array}$ & $\begin{array}{c}1: 50.000 \mathrm{a} \\
1: 1.500 .000\end{array}$ & $\begin{array}{c}\text { MNT, Imagens, } \\
\text { Mapas } \\
\text { Temáticos }\end{array}$ & $\begin{array}{l}\text { Grades, } \\
\text { Matricial, } \\
\text { Vetorial }\end{array}$ & - Visualização 3D \\
\hline $\begin{array}{l}\text { Redes (serviços } \\
\text { de utilidade } \\
\text { pública, redes de } \\
\text { drenagem e } \\
\text { rodovias) }\end{array}$ & $\begin{array}{l}1: 1.000 \mathrm{a} \\
1: 10.000\end{array}$ & $\begin{array}{l}\text { Redes lineares } \\
\text { (Topologia) }\end{array}$ & Vetorial & $\begin{array}{ll}\text { - } & \text { Consulta } \\
\text { espacial, } \\
\text { - Cálculos } \\
\text { dedicados }\end{array}$ \\
\hline $\begin{array}{c}\text { Estudos Urbanos } \\
\text { e Rurais }\end{array}$ & $\begin{array}{l}1: 1.000 \mathrm{a} \\
1: 25.000\end{array}$ & $\begin{array}{c}\text { Redes, } \\
\text { Cadastro } \\
\text { urbano e rural }\end{array}$ & Vetorial & $\begin{array}{l}\text { - Consulta } \\
\text { espacial }\end{array}$ \\
\hline $\begin{array}{c}\text { Estudos Sociais e } \\
\text { Econômicos }\end{array}$ & Várias & $\begin{array}{c}\text { Dados } \\
\text { alfanuméricos, } \\
\text { Cadastros }\end{array}$ & - & $\begin{array}{l}\text { - Consulta } \\
\text { espacial, } \\
\text { - Cálculos } \\
\text { dedicados }\end{array}$ \\
\hline
\end{tabular}

* MNT - Modelo Numérico do Terreno.

Fonte: Adaptado de Câmara e Medeiros (1998).

\subsubsection{Sistema de informações geográficas}

Um SIG é desenvolvido com finalidades específicas para trabalhar com informações geograficamente referenciadas. São programas que incluem recursos para dados de entrada, além do armazenamento, manipulação, análise e saída de dados. Suas análises podem ser simples ou complexas, úteis nas tomadas de decisão (MICHAEL; STEPHEN; PALLADINO, 1995).

O SIG vem avançando tecnologicamente desde o final de 1970, com relação às capacidades técnicas e de processamento, e em tempos atuais são utilizados em todo o mundo para diversas finalidades (HUISMAN; BY, 2009). Os SIGs no Brasil começaram a ser utilizados na década de 80 e são ferramentas específicas para o geoprocessamento. A primeira aplicação destes programas foi no mapeamento básico, pela carência de dados ambientais, rurais e urbanos (LADWIG, 2012). 
De acordo com Huisman e By (2009) os dados de entrada em SIG, em formato vetorial ou matricial (vetor ou raster, respectivamente) podem apresentar vantagens e desvantagens, conforme apresenta a Tabela 13.

Tabela 13 - Vantagens e desvantagens dos formatos dos dados de entrada em um SIG.

\begin{tabular}{|c|c|}
\hline Vantagens & Desvantagens \\
\hline \multicolumn{2}{|c|}{ RASTER } \\
\hline Estrutura de dados simples & Estrutura de dados mais compacta \\
\hline Implementação simples de sobreposições & Dificuldades em representar topologia \\
\hline Eficiente para o processamento de imagem & $\begin{array}{l}\text { Limites das células não são iguais aos limites da } \\
\text { característica }\end{array}$ \\
\hline \multicolumn{2}{|c|}{ VETOR } \\
\hline Representação eficiente da topologia & Estrutura de dados complexa \\
\hline Adapta-se bem às mudanças de escala & Sobreposição mais difícil de implementar \\
\hline Permite fácil associação com dados do atributo & $\begin{array}{l}\text { Ineficiente para processamento de imagem, e } \\
\text { necessita de atualização mais intensiva }\end{array}$ \\
\hline
\end{tabular}

As técnicas de geoprocessamento junto ao SR podem ser utilizadas em vários estudos de tratamento da informação geográfica. Os dados adquiridos pelos sistemas orbitais (imagem de satélite), conectados a mapas e bancos de dados, através de um SIG, resultam em novos produtos e informações (ROCHA; SEER, 2008). A Figura 7 apresenta os componentes de um SIG.

Figura 7 - Estrutura dos dados de entrada e saída de um SIG.

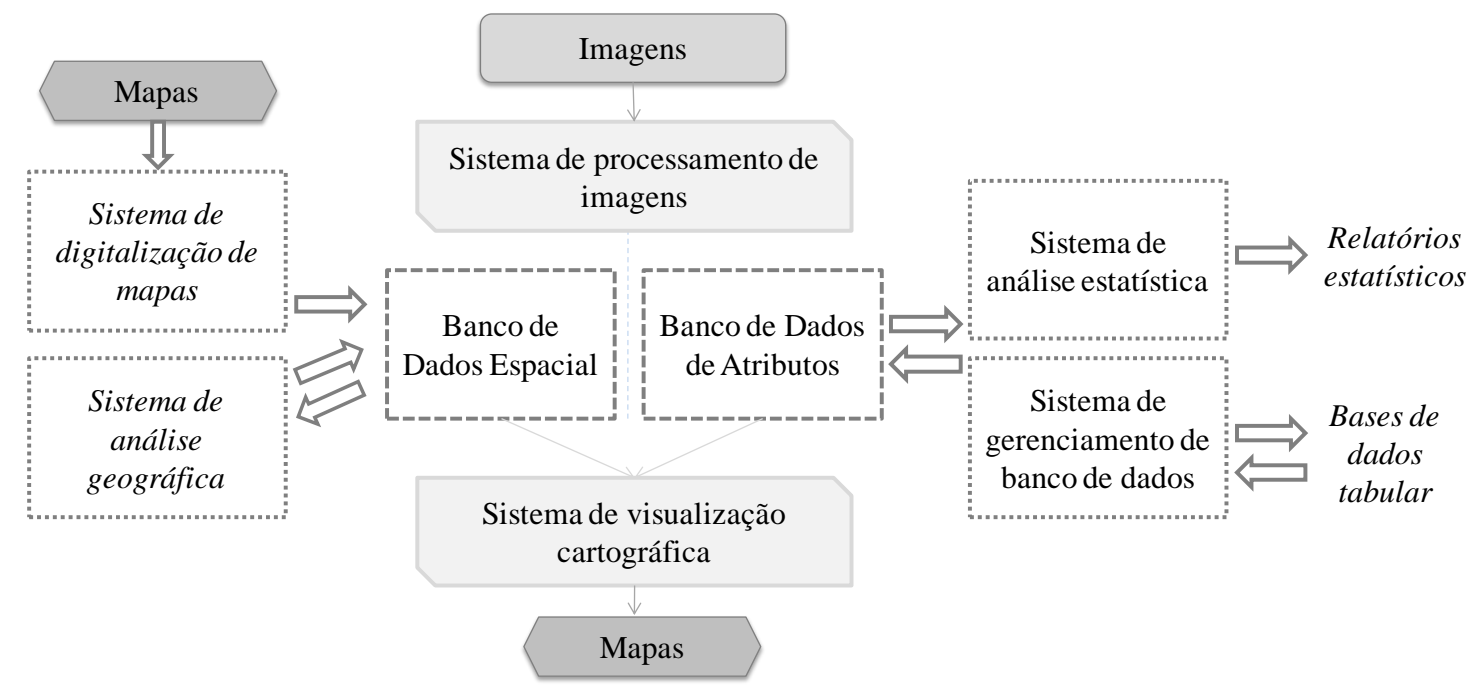

Fonte: Adaptado de Eastman (1992). 
Segundo Coelho (2009), o SIG vem sendo definido como um instrumento fundamental nas tomadas de decisão. Este se diferencia dos outros sistemas computacionais, por ser capaz de estabelecer relações espaciais entre elementos gráficos, o que é mais adequado para preparar e analisar os dados geográficos.

Para Câmara e Medeiros (1998), um SIG apresenta alguns elementos que permitem a interface com o usuário, a entrada e conexão dos dados, processamentos gráficos e de imagens, visualização e plotagem, armazenamento e recuperação de dados. Estes elementos são organizados de maneira a se formar um banco de dados digital de informações geográficas. Conforme os autores podem ser citados pelo menos quatro campos relacionados aos estudos ambientais que fazem uso de um SIG, sendo eles: mapeamento temático, diagnóstico ambiental, avaliação de impacto ambiental e ordenamento territorial.

Conforme Augusto Filho (2013) existem vários programas de SIG disponíveis no mercado, portanto é possível identificar um conjunto de características similares a todos eles, como: fazem o uso de meios digitais; necessitam de uma base de dados integrada, georreferenciada e que tenham controle de erro; possuem funções de análise de dados; executam operações algébricas simples, complexas e lógicas; e relacionam-se com diferentes técnicas digitais e computacionais, como os bancos de dados, desenho digital, sensoriamento remoto. Para o autor, outra característica muito importante destes programas é ser de natureza dual, por fazer uso de um banco de dados relacional (tabelas nas quais as linhas apresentam dados e as colunas apresentam seus atributos) tendo como objetivo manter as informações dos objetos geográficos.

\subsubsection{Sensoriamento remoto}

Conforme Florenzano (2007), o Sensoriamento Remoto (SR) é uma tecnologia utilizada para a obtenção de imagens da superfície terrestre, através do processo de captação e do registro da energia que reflete ou emite para a superfície. O termo sensoriamento é compreendido pela aquisição de dados através de sensores instalados em plataformas terrestres, aéreas (balões e aeronaves) e orbitais (satélites artificiais). Já o termo remoto é utilizado devido à obtenção ser realizada sem o contato físico entre o sensor e os objetos presentes na superfície terrestre, ou seja, o processo é realizado à distância. 
O SR se destaca com um grande potencial de técnicas, que disponibiliza diferentes cenários de desenvolvimento para uma determinada área. A utilização destas técnicas pode suprir as necessidades, tais como: elaboração e atualização de mapas básicos de uso de solo (como áreas de agricultura, expansão urbana, vegetação, recursos hídricos, geotécnico, entre outras). As geotecnologias são consideradas um verdadeiro marco da tecnologia em benefício da humanidade, pois elas despertam um maior interesse na elaboração de projetos e mapeamento de diferentes regiões (OLIVEIRA; SOARES; NISHIYAMA, 2011).

Para Liu (2007) este termo de SR é interpretado como uma técnica utilizada para obter e aplicar as diversas informações em um objeto sem que ocorra algum contato físico. Os sensores encontrados nos satélites apresentam como função capturar as energias eletromagnéticas da superfície do planeta, não sendo necessário o contato com ela. A informação é obtida por meio da detecção e aferição das alterações que o objeto atribui ao campo de entorno, visto que este sinal pode abranger um campo eletromagnético emitido e/ou refletido.

O SR proporciona espacialmente um melhor entendimento das características físicas, como: usos do solo; modelos de crescimento; espacialização de recursos; impactos ambientais; entre outros. Não somente relacionadas ao meio físico, mas também as necessidades do meio social e econômico do ambiente (PULLEN; PATTERSON, 2011).

De acordo com Steffen, Moraes e Gama (1996) as energias eletromagnéticas apresentam denominações que são tanto da natureza histórica, ou resultante dos processos utilizados na sua produção ou determinação. A Tabela 14 apresenta estas energias e algumas de suas considerações.

Tabela 14 - Considerações gerais sobre as energias eletromagnéticas, segundo Steffen, Moraes e Gama (1996).

\begin{tabular}{c|l}
\hline $\begin{array}{c}\text { Energia } \\
\text { Eletromagnética }\end{array}$ & \multicolumn{1}{c}{ Informações gerais } \\
\hline Radiação Gama & $\begin{array}{l}\text { Este tipo de energia é emitida por materiais radioativos e pela luz solar. } \\
\text { Apresenta alta frequência, isso faz com que seja muito penetrante. }\end{array}$ \\
\hline Raios $X$ & $\begin{array}{l}\text { Surgem no interior da eletrosfera do átomo, por meio de rearranjos } \\
\text { eletrônicos. Apresenta grande uso nos estudos de estruturas cristalinas de } \\
\text { sólidos. }\end{array}$ \\
\hline
\end{tabular}


Tabela 14 - Considerações gerais sobre as energias eletromagnéticas, segundo Steffen, Moraes e Gama (1996) (continuação).

\begin{tabular}{|c|c|}
\hline $\begin{array}{c}\text { Energia } \\
\text { Eletromagnética }\end{array}$ & Informações gerais \\
\hline $\begin{array}{l}\text { Radiação } \\
\text { Ultravioleta } \\
\quad(U V)\end{array}$ & $\begin{array}{l}\text { Esta radiação é produzida em grande proporção nas reações nucleares no } \\
\text { sol. Contudo, ao alcançar o extremo da atmosfera terrestre ela é quase } \\
\text { totalmente absorvida pelo gás ozônio }\left(\mathrm{O}_{3}\right) \text {. O espectro do UV é dividido em } \\
\text { três bandas: } \\
\text { 1) UV próximo: } 0,3 \text { a } 0,38 \mu \mathrm{m} \text {; } \\
\text { 2) UV distante: } 0,2 \text { a } 0,3 \mu \mathrm{m} \text {; } \\
\text { 3) UV máximo: } 0,1 \text { a } 0,2 \mu \mathrm{m} \text {. }\end{array}$ \\
\hline $\begin{array}{c}\text { Radiação Visível } \\
\text { (LUZ) }\end{array}$ & $\begin{array}{l}\text { São as radiações eletromagnéticas entre os comprimentos de ondas que } \\
\text { variam de } 0,39 \mathrm{~mm} \text { a } 0,70 \mathrm{~mm} \text {. As radiações encontradas nesta faixa de } \\
\text { comprimento de onda, ao incidir no sistema visual humano, apresentam a } \\
\text { capacidade de provocar uma sensação de cor. }\end{array}$ \\
\hline $\begin{array}{l}\text { Radiação } \\
\text { Infravermelha } \\
\quad(I V)\end{array}$ & $\begin{array}{l}\text { São encontradas no espectro eletromagnético entre a luz vermelha até o } \\
\text { microondas. Pode ser conhecida como a radiação térmica, e dividida em três } \\
\text { faixas espectrais: } \\
\text { 1) IV próximo: } 0,7 \text { a } 1,1 \mu \mathrm{m} \text {; } \\
\text { 2) IV médio: } 1,1 \text { a } 3,0 \mu \mathrm{m} \text {; } \\
\text { 3) IV distante: } 3,0 \text { a } 1000 \mu \mathrm{m} \text {. }\end{array}$ \\
\hline Microondas & $\begin{array}{l}\text { São situados na região do espectro de } 14,0 \mu \mathrm{m} \text { até cerca de } 1 \times 10^{-6} \mu \mathrm{m} \text {. } \\
\text { Neste limite de onda podem-se construir dispositivos que apresentem a } \\
\text { capacidade de fornecer feixes de alta radiação eletromagnética, } \\
\text { denominados, como radares. Quando se tem pouca intensidade pela } \\
\text { atmosfera, ou nuvens, se destacam como um importante meio para uso de } \\
\text { sensores de microondas independentes das condições do tempo. }\end{array}$ \\
\hline Ondas de Rádio & $\begin{array}{l}\text { Apresentam baixas frequências e grandes comprimentos de onda. As ondas } \\
\text { são utilizadas na área da comunicação por propagar em grandes distâncias. } \\
\text { Outro motivo é de serem pouco atenuadas pela atmosfera, sendo refletidas } \\
\text { para a ionosfera. É definida como um conjunto de radiações de frequência } \\
\text { inferiores a } 1 \mathrm{~m} \text {, o que corresponde a } 300 \mathrm{MHz} \text {. }\end{array}$ \\
\hline
\end{tabular}

Para Novo (1992) o SR é visto como um sistema de obtenção de informações e pode ser subdividido em dois subsistemas, sendo eles: subsistema de coleta de dados e subsistema de análise de dados, conforme apresenta a Figura 8. 
Figura 8 - Componentes básicos do sistema de aquisição de informações por SR.

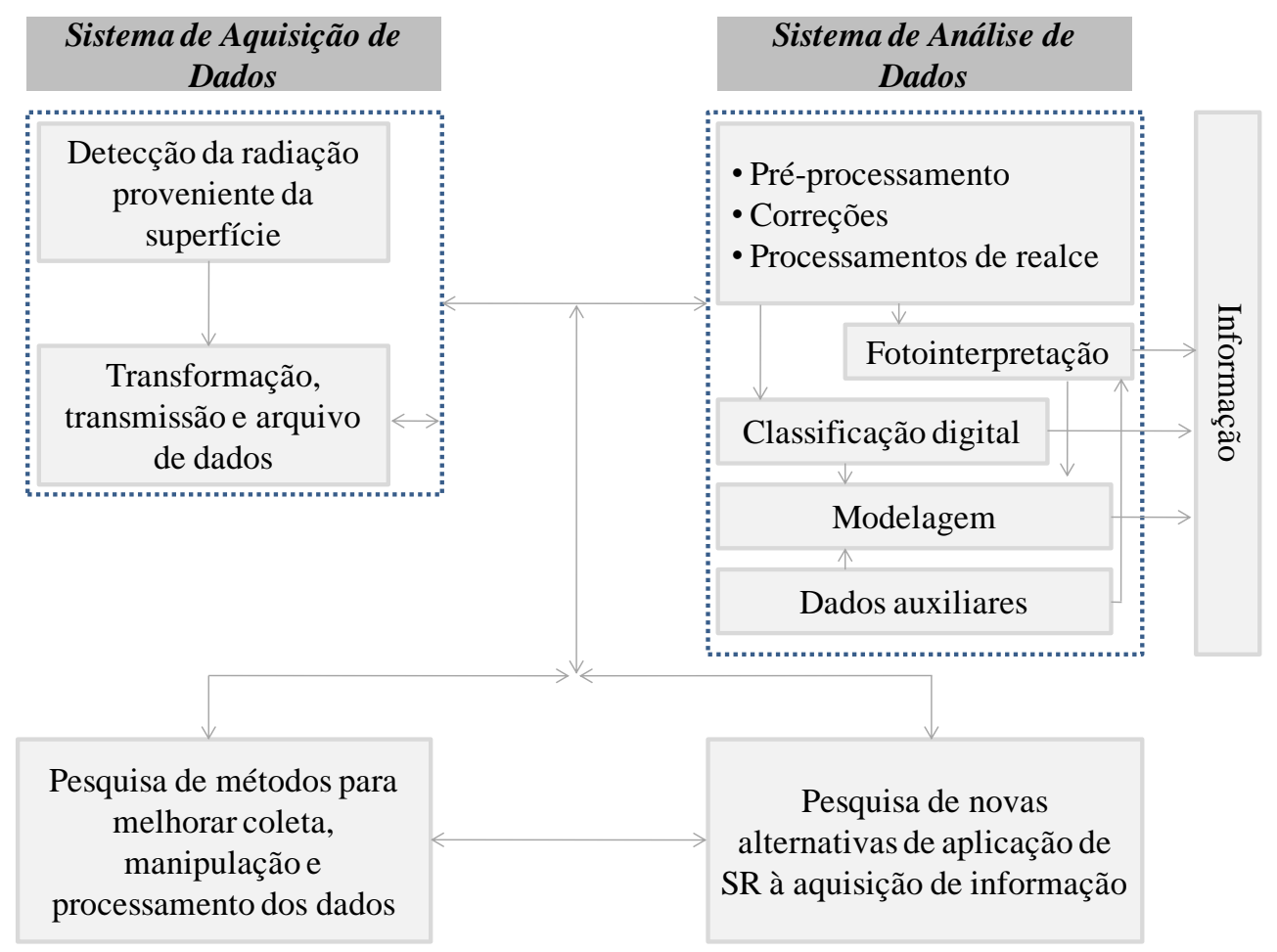

Fonte: Adaptado de Novo (1992).

\subsubsection{Produtos utilizados para aquisição de informações remotas}

As imagens de satélite são consideradas como produtos de sensoriamento remoto, que possibilitam maior facilidade em controlar e monitorar os aspectos e fenômenos naturais e antrópicos sobre o espaço terrestre, permitindo dessa forma, realizar uma análise temporal e identificar alterações na superfície. Estas alterações podem ser transformadas em informações gráficas (CONCEIÇÃO; COSTA, 2011).

Para Câmara e Monteiro (2004) é necessário considerar algumas características básicas das imagens de satélite, conforme mostradas na Tabela 15.

Tabela 15 - Tipos de resoluções importantes de uma imagem de satélite, segundo Câmara e Monteiro (2004).

\begin{tabular}{c|l}
\hline \multicolumn{2}{c}{ Características importantes de uma imagem de satélite } \\
\hline Resolução Espectral & $\begin{array}{l}\text { O número e a largura de bandas do espectro eletromagnético } \\
\text { imageadas }\end{array}$ \\
\hline Resolução Espacial & $\begin{array}{l}\text { A menor área da superfície terrestre observada instantaneamente por } \\
\text { cada sensor }\end{array}$ \\
\hline Resolução Radiométrica & Nível de quantização registrado pelo sistema sensor \\
\hline Resolução Temporal & O intervalo entre duas passagens do satélite pelo mesmo ponto \\
\hline
\end{tabular}


Segundo Liu (2007) as imagens podem ser classificadas com base em diferentes métodos, compreendendo duas categorias distintas, sendo: classificação supervisionada e classificação não-supervisionada.

De acordo com o mesmo autor, os métodos de classificação supervisionada são baseados em classificadores que utilizam parâmetros estatísticos na análise e comparação das características de reflectâncias espectrais dos pixels com características de uma determinada classe de padrão para a classificação e delimitação das classes das imagens digitais. Os métodos de classificação mais comuns incluem: Análise de Componente Principal (Principal Component Analysis - PCA), Classificador de Máxima Verossimilhança (Maximum Likely hood Classifier - MLC), Modelo de Matrizes Co-Ocorrências de Nível de Cinza (Grey Level Co-occurrence Matrix - GLCM), Krigagem, Modelo de Mistura Linear (Linear Mixture Model - LMM), entre outros.

Os métodos de classificação não-supervisionada são estabelecidos na análise de agrupamento (Cluster Analysis) que utiliza os critérios estatísticos dos dados de amostragem, tais como média, desvio-padrão, variância, entre outros. Visto que, os algoritmos dos métodos mais comuns incluem ISODATA e K-Means (LIU, 2007).

Além das imagens de satélite existem outros produtos que auxiliam na obtenção das informações remotas, como as fotografias aéreas e as ortofotos. Segundo Longley et al. (2013) as fotografias aéreas são muito utilizadas em projetos de detalhe de levantamento e mapeamento. A maioria das fotografias aéreas é adquirida conforme a necessidade, para obtenção destes produtos é necessário à utilização de câmeras acopladas em aviões que realizam vôos entre altitudes de 3.000 a 9.000 metros. Elas podem ser tanto pancromáticas (preto e branco) quanto coloridas, sendo que câmeras e sensores multiespectrais que atuam em porções não visíveis do espectro eletromagnético, também são utilizados.

De acordo com Panizza e Fonseca (2011), mesmo sendo muito utilizadas, as fotografias aéreas apresentam algumas desvantagens, que atualmente já estão sendo superadas nas imagens de satélite. Para as autoras, a obtenção das fotografias aéreas necessita de cuidados especiais quanto à programação de vôo, além de depender: das ótimas condições climáticas; horário adequado, sendo que a posição do sol influencia na projeção das sombras e dos reflexos; e da velocidade constante do avião. 


\subsection{Zoneamento ambiental e geoambiental}

\subsubsection{Zoneamento ambiental}

Para Foleto e Ziani (2013) existem diferentes tipos de zoneamento, dentre eles o Zoneamento Ambiental (ZA) se destaca por ser empregado na identificação das características ambientais de uma determinada área, analisando suas potencialidades, aptidões e restrições, em busca de provocar menor impacto possível na área, colaborando com o ordenamento territorial e o desenvolvimento sustentável. A classificação das zonas depende do nível de intervenção, além disso, existem outros critérios que são levados em consideração, como o grau de intervenção humana, regulamentação fundiária, percentual de proteção e limites perceptíveis na paisagem.

Para Batistela (2007), o ZA é considerado como um instrumento preventivo, que tem como função acompanhar o desenvolvimento socioeconômico visando uma relação com os objetivos de preservação da qualidade do meio ambiente e a utilização dos recursos naturais de forma sustentável.

Segundo Folharini e Oliveira (2013), o ZA conceituado dentro da temática de planejamento é uma ferramenta com o objetivo de ordenar adequadamente a utilização do espaço, analisando os aspectos que apresentam maior relevância, que podem ser físicos e humanos, determinando a dinâmica de uma respectiva área. O ZA é uma proposta para minimizar as intervenções negativas causadas pela atuação do homem na natureza, destacando uma nova organização dos espaços que estrutura a paisagem (SILVA NETO, 2013).

Dorneles (2010) diz que o ZA é uma ferramenta de extrema importância nos planos diretores, sua execução assegura o controle de uma área aos gestores dos municípios, sobre as atividades relacionadas à sociedade, economia, turismo, e o desenvolvimento das regiões.

Dentre os usos e a importância do ZA, vários autores utilizaram este instrumento para subsidiar seus estudos quanto às análises do meio físico, biótico e socioeconômico, de uma determinada região, com a finalidade de melhorar a condição ambiental e físicoterritorial. 
O estudo de Cemin et al. (2012), também abordou o ZA como instrumento de planejamento, tendo como objetivo elaborar um zoneamento no município de Nova Alvorada (RS) utilizando dados sobre os meios físico e biótico, para auxiliar na elaboração das metas e diretrizes para o uso racional dos recursos naturais.

Lopes, Cestaro e Kelting (2012) utilizaram o ZA no município de Aquiraz (CE) para auxiliar os gestores públicos para uma melhor disciplina do uso e ocupação do solo, além do gerenciamento das atividades socioeconômicas, para fins de estabelecer as áreas adequadas para o desenvolvimento urbano e para as atividades de turismo e de lazer da população.

Oliveira et al. (2011), aplicaram o ZA na bacia hidrográfica do Ribeirão Salobra (MS), os autores apresentaram como uma das funções do ZA a capacidade de gerenciar o uso do solo e dos recursos hídricos, através deste conceito, a aplicação do instrumento no trabalho foi para a conservação do solo e da água na bacia hidrográfica. O zoneamento envolveu os seguintes dados: uso permissível e atual do solo; risco de erosão e APP.

No trabalho de Thomas (2012), foi apresentada uma proposta de ZA, no município de Arroio do Meio (RS), para auxiliar no desenvolvimento da região, respeitando o meio ambiente e os usos já existentes, devido o município apresentar em seu limite espacial atividades econômicas que indicam riscos potenciais de degradação, como exemplo, as práticas agrícolas intensivas. Para a efetivação do ZA foram utilizadas cinco variáveis ambientais (recursos hídricos, cobertura florestal, declividade, áreas urbanas e intervenções antrópicas), além de áreas identificadas em locais que apresentam restrições legais.

Foleto e Ziani (2013) elaboraram o mapa de ZA do Parque do Morro em Santa Maria (RS), utilizando quatro mapas: hipsométrico (190m até 430m); declividade (0 a >47\%); APPs (APPs com declividade maior que $45^{\circ}$, APPs das nascentes dos rios, APPs das margens dos rios); cobertura do solo (floresta, floresta densa, campo, solo exposto). Através da combinação destes planos de informação foram definidos pelas autoras cinco classes para o mapa de ZA, sendo elas: "zona primitiva", visto que esta é a classe que se apresenta em maior área, o segundo tipo de uso foi classificado como "zona de uso intensivo", a terceira classe compreende as áreas naturais e é denominada de "zona de uso extensivo", a "zona de uso especial" destaca-se como a classe que apresenta menor extensão, e por fim o estabelecimento da "zona de recuperação" que dependeu dos mapas hipsométrico, de cobertura do solo e das APPs. 
Como no Brasil, outros países adotam também em suas áreas a implementação do ZA, como exposto no trabalho de Palomo et al. (2014), que envolveu a elaboração de mapas de zoneamento para duas áreas protegidas da Espanha, sendo ambas situadas na Andaluzia, visto que a primeira se encontra no final da cabeceira da bacia hidrográfica do Rio Guadalquivir (Doñana) e a outra na cabeceira da bacia hidrográfica (Sierra Nevada). Os mapas de zoneamento das duas áreas envolveram as seguintes classes: zona de reserva; zona de uso restrito; zona de uso moderado; zona uso especial; e zona de proteção. Além destas áreas, foram consideradas outras áreas, como: zona de regularização especial; zona de regularização comum e áreas sem zoneamento.

\subsubsection{Zoneamento geoambiental}

De acordo com Silva e Dantas (2010) os estudos geoambientais são utilizados na avaliação de impactos sobre o meio físico, na recuperação de áreas degradadas, no monitoramento ambiental, em auditorias ambientais e na investigação de passivo ambiental. Por meio da integração de dados sobre relevo, substrato rochoso, recursos hídricos, pedologia e uso e ocupação, o estudo geoambiental proporciona diversas informações sobre os espaços geológicos em que se desenvolveram os terrenos e evidencia as potencialidades e as restrições quanto ao uso e ocupação do solo. Além disso, pode fornecer informações que previnem as catástrofes referentes às causas naturais ou as atividades humanas.

Segundo os mesmos autores, o conceito geoambiental, adotado pela International Union of Geological Sciences (IUGS) foi elaborado para designar a atuação dos profissionais das áreas das geociências em meio ambiente. Essa atuação considera os conhecimentos técnicos associados ao meio físico aos diferentes instrumentos e mecanismos da gestão ambiental, através da cartografia, que utiliza o SIG e o banco de dados.

Dessa forma o Zoneamento Geoambiental (ZG) aparece como um instrumento de auxílio ao planejamento e ordenamento territorial, uma vez que após executado pode subsidiar o plano diretor, apresentando informações de cunho ambiental ao setor da gestão municipal, de forma a contribuir com o uso sustentável e a gestão ambiental mais eficiente (OLIVEIRA, 2012).

Para Grecchi (1998) o ZG pode ser entendido como uma ferramenta de subsídio ao planejamento e o ordenamento territorial, independente da escala, podendo ser tanto regional 
ou local. Estes estudos proporcionam a caracterização de áreas, identificando as suas aptidões e limitações quanto às atividades atuantes e também as atividades que poderão ser implementadas, bem como a indicação dos espaços territoriais que apresentam um maior nível de qualidade ambiental, tendo em vista a sua preservação.

De acordo com Dias, Tretin e Sccoti (2015) o ZG busca definir, por meio sistêmico, as restrições e as potencialidades da paisagem, visto que a área pode ser estudada tanto considerando o limite de uma bacia hidrográfica, como também o limite municipal ou até mesmo uma unidade de federação, de modo que se estabeleça uma correlação entre o atributo de uso e a ocupação e a geomorfologia.

Os procedimentos metodológicos utilizados por De Nardin e Robaina (2010) no ZG das bacias hidrográficas dos afluentes do Rio Ibicuí (RS), envolveram em primeiro momento a compartimentação da paisagem considerando as características geoambientais com as atividades humanas, evidenciando o potencial e as limitações de uso. Para o ZG também foram considerados os métodos propostos por Zuquette (1987), que diz que este processo tem como função o levantamento, avaliação e análise dos atributos que constituem o meio físico. O método considerado para a confecção do produto cartográfico envolveu quatro categorias de informações, sendo elas: básicas; derivadas; interpretativas e finais. A Figura 9 apresenta as etapas envolvidas na elaboração do ZG.

Figura 9 - Etapas para a elaboração do mapa de zoneamento geoambiental.

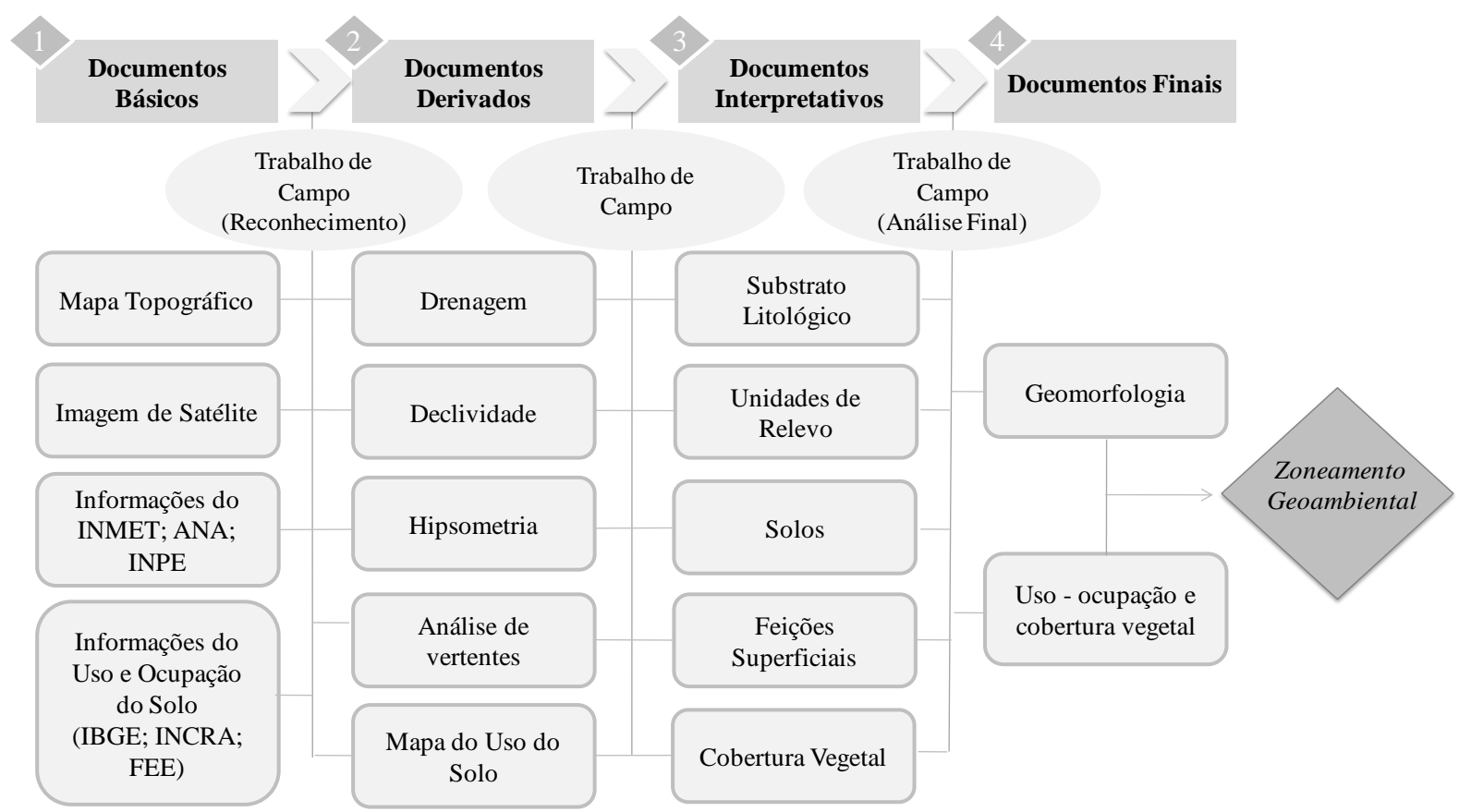

Fonte: Adaptado de De Nardin e Robaina (2010). 
Lisboa e Ferreira (2011) elaboraram o ZG no município de Colorado D' Oeste (RO), com o propósito de diagnosticar e estabelecer diretrizes para o fortalecimento da gestão territorial. Para isto, utilizaram as técnicas de SR e geoprocessamento, o que possibilitou a caracterização e divisão fisiográfica do meio físico, identificando as unidades e subzonas geoambientais, podendo ainda conhecer as condições de capacidade de suporte natural da área de estudo. O ZG abrangeu atributos relacionados com: a fisiografia, o regime hídrico, a fertilidade do solo e as ações antrópicas. Os autores elaboraram o mapa do ZG considerando três áreas distintas: institucionais; consolidadas por usos controlados; consolidadas por usos restritos.

- A primeira área é compreendida pelas áreas protegidas de uso restritivo e controlado, previstas em Lei e instituídas pela União, Estado e municípios (como exemplo: áreas das planícies de inundação, ou áreas com declividades elevadas), sendo que esta se divide em duas zonas.

- A segunda área registra-se uma ocupação consolidada, com diversos usos, principalmente as atividades agropecuárias, esta área apresenta vários níveis de vulnerabilidade ambiental, portanto foi dividida em quatro zonas distintas.

- Por fim, a terceira apresenta duas zonas e é compreendida também por uma área com várias utilidades, porém apresenta restrições ao uso devido apresentar características e propriedades naturais que a torna susceptível a processos erosivos.

Geneletti e Van Duren (2008) elaboraram o zoneamento do Parque Paneveggio-Pale di S. Martino (Itália) utilizando a técnica da análise de decisão de multicritério. Em primeiro momento a área do parque foi compartimentada em unidades homogêneas que representam os elementos espaciais básicos. Logo foi atribuído o nível de proteção para cada unidade, dessa forma o mapa de zoneamento foi elaborado em três classes: a primeira zona teve como finalidade proteger rigorosamente o ambiente e os ecossistemas, de forma a minimizar as pressões antrópicas; a segunda zona consistiu na proteção histórico-cultural da área permitindo o uso do solo; e a terceira zona teve como função diminuir os impactos indesejáveis, bem como a implantação de infraestruturas para apoiar o desenvolvimento da área com práticas turísticas e recreativas.

Segundo Menezes e Zuquette (2004) os atributos mínimos necessários para alguns ordenamentos do meio físico que utilizam como ferramenta o ZG, está apresentado na Tabela 16. 
Tabela 16 - Atributos utilizados para o zoneamento geoambiental.

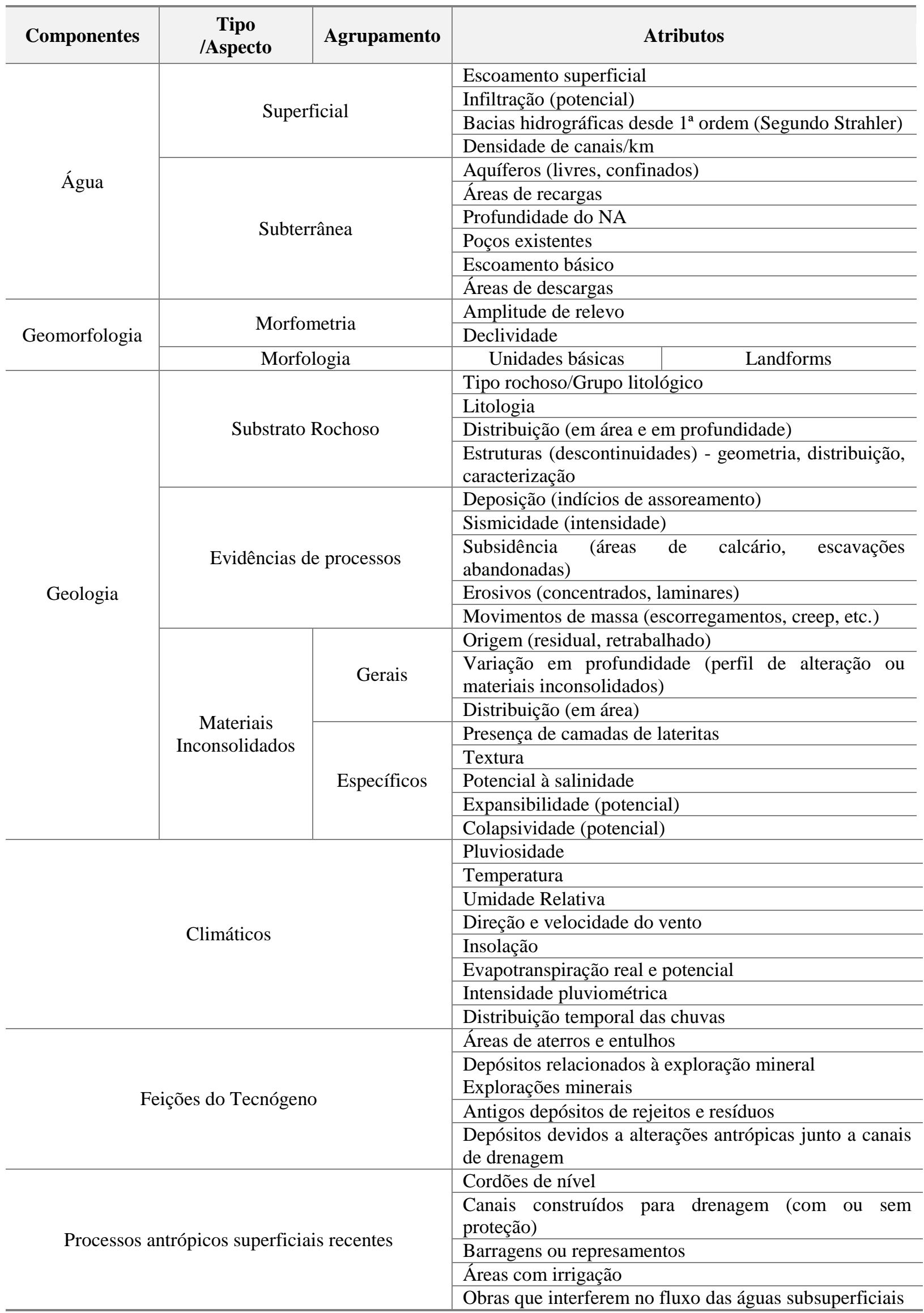

Fonte: Modificado de Menezes e Zuquette (2004). 


\subsection{Mapeamento geológico-geotécnico e geoambiental}

A interpretação visual consiste em um enorme recurso para o estudo da paisagem ambiental. No entanto, é indispensável o estudo da área avaliada, o que ajuda na identificação e descrição de diferentes alvos. Sendo assim, os produtos cartográficos, tem grande importância na validação quantitativa da precisão do mapeamento (FRANÇA; IBANEZ; FERREIRA, 2005).

Segundo Zuquette e Nakazawa (1998), os produtos cartográficos compreendem documentos de diferentes denominações, os quais podem ser designados nas seguintes categorias:

- cartas geotécnicas propriamente ditas: demonstram as limitações e potencialidades de uma determinada área e estabelecem diretrizes de ocupação para os diferentes tipos de uso do solo;

- carta de risco: avalia o dano potencial à ocupação, considerando uma ou mais características naturais ou antrópicas;

- cartas de suscetibilidade: exibem a probabilidade de acontecimento de um ou mais fenômenos naturais ou antrópicos;

- cartas de atributos ou parâmetros: apresentam a distribuição espacial de uma ou mais características (geotécnicas, geológicas, entre outras) do terreno.

Conforme Pejon (1992), os estudos de mapeamento geotécnico devem possuir uma estrutura que se divide em três fases principais com base no método científico.

- A primeira fase contempla a observância do problema a ser estudado, envolvendo a definição de uma hipótese de trabalho. Com relação aos processos de mapeamento geotécnico, envolvem o estabelecimento e a análise do grupo de atributos do meio físico. Para estes atributos é necessário levar em conta a sua importância, em função da inter-relação entre os atributos e o objetivo do estudo.

- A segunda fase abrange a criatividade e a indução, compreende a etapa de classificação. No mapeamento ocorre a divisão da área em várias unidades seguindo as características e relações dos atributos considerados. Estas unidades são definidas como locais homogêneos quanto às propriedades dos componentes do meio físico analisados. Tal procedimento pode ser entendido de forma geral como o início do zoneamento geotécnico. 
- A terceira fase faz uso de técnicas experimentais, a vista disso, em um processo de mapeamento geotécnico, como as áreas delimitadas apresentam característica bem próximas, devem ser validadas através de testes e ensaios laboratoriais, caso necessário abrangendo também métodos estatísticos.

O mapeamento geotécnico define a representação, em ambiente cartográfico, dos elementos geológico-geotécnicos que apresentam significância quanto ao uso e ocupação do solo e do subsolo em projetos de construção e manutenção utilizados em engenharia civil, de minas e até mesmo em causas ambientais. Com este processo de mapeamento pode-se identificar as unidades geotécnicas de cada área, juntamente com informações relacionadas à tipologia do solo, substrato rochoso e relevo predominante na área analisada (ZUQUETTE, 1993).

Vedovello e Mattos (1993) entendem o mapeamento geotécnico como o conjunto de procedimentos realizados para coletar informações geotécnicas, como exemplo de procedimentos cita-se: a fotointerpretação, os inventários, os trabalhos de campo, as análises e os ensaios físico-químicos "in situ” ou laboratoriais, entre outros. Estas informações estão relacionadas com o levantamento de propriedades e características do meio físico-geológico, que devem ser determinantes no comportamento dos solos e rochas desse meio, levando em consideração às atividades modificadoras do meio físico, provocadas pelas ações humanas.

Para Fell et al. (2014) o mapeamento geotécnico é essencialmente o mapeamento geológico aplicado em qualquer campo específico que necessita da localização e plotagem de dados em escala adequada e entendimento das condições geotécnicas, como exemplo na solução de questões que envolvem a engenharia.

Segundo Zaine (2000), o mapeamento geológico-geotécnico considera as propriedades e a gênese das rochas e dos solos, sendo respectivamente relacionadas às características geotécnicas e geológicas. No mapeamento ocorre a junção de um grande número de dados e análises para toda uma área, integrando os atributos do meio físico, para serem utilizados no planejamento de uma nova ocupação ou para a correção dos problemas de natureza geológicogeotécnica.

Coelho, Alves e Oliveira (2007) realizaram o mapeamento geológico e geotécnico para a elaboração do mapa de potencial de uso e ocupação do município de Itaperuna (RJ). Para isto foi confeccionado o mapa pedológico e geomorfológico da área que após a 
sobreposição destes dois planos de informação foi elaborado o mapa das unidades geológicogeotécnica. A sobreposição deste último mapa com a declividade resultou no mapa final (potencial ao uso e ocupação do solo).

O trabalho de Rodrigues (2008) envolveu o mapeamento geotécnico para fornecer subsídios do meio físico para instrumentos de planejamento tanto urbano quanto municipal, principalmente relacionado aos planos diretores. A metodologia utilizada no trabalho da autora foi de Mathewson e Font (1974), portanto, os documentos cartográficos produzidos foram classificados em mapas de $1^{\mathrm{a}}$ ordem (observação); $2^{\mathrm{a}}$ ordem (engenharia); $3^{\mathrm{a}}$ (adequação aos recursos) e $4^{\mathrm{a}}$ ordem (planejamento). Os documentos podem ser tanto para uso técnico quanto público e privado, como:

- Para uso técnico (mapas de $1^{\mathrm{a}}$ e $2^{\mathrm{a}}$ ordem): topografia; litológico; geológico; tectônica; solos agrícolas; drenagem superficial; capacidade de infiltração; qualidade do solo e da rocha; estabilidade de taludes, entre outros.

- Para uso público e privado (mapas de $3^{a}$ e $4^{a}$ ordem): adequação para instabilidade subterrânea; adequação para depósitos de rejeitos, entre outros.

Zuquette (1987) define que uma das limitações na elaboração de mapeamentos geotécnicos é a acepção dos atributos a serem considerados. Pois, os atributos escolhidos devem se relacionar com os demais, para a efetivação do produto desejado. Desse modo, quanto maior o número de elementos representados ao qual um determinado atributo se interrelaciona, é admitida maior importância de sua representação.

Assim como o mapeamento geológico-geotécnico, o geoambiental está cada vez mais ganhando espaço nos estudos científicos de uma determinada área, apesar de ser mais recente, este apresenta uma grande importância na compreensão das características físicas e das ações humanas de um determinado espaço. A seguir, estão sendo mostrados alguns estudos que utilizaram este tipo de mapeamento.

Conforme Schirmer (2012), o mapeamento geoambiental de um município se executa quando se pretende determinar as restrições e potencialidades ambientais. O mapa geoambiental é elaborado para apresentar a espacialização hierárquica em sistemas e unidades, considerando as características do meio físico, de forma a identificar as áreas que apresentam limitações. Para o autor, os mapas geoambientais unem as informações de diversas temáticas como: geologia, recursos minerais, geomorfologia, solos, aptidão agrícola, 
geoquímica, geofísica, geotecnia, riscos geológicos, uso e ocupação dos solos, cobertura vegetal, clima, águas superficiais e subterrâneas. O processamento destas informações através de sobreposição e correlação conduz a um documento cartográfico que auxilia o planejamento, a gestão e o ordenamento físico-territorial.

Sccoti (2015) destaca que o mapeamento geoambiental consiste em um método que divide de forma hierárquica a área de estudo em diversas classes de terreno, com base nas características gerais geológico-geomorfológicas e também no uso do solo. Assim, a junção dessas informações proporciona a setorização da área em porções mais homogêneas, nas quais é possível identificar as potencialidades e limitações de cada setor.

O trabalho de Khawlie (2002) apresenta treze indicadores que podem ser considerados para a elaboração de um estudo geoambiental, dentre eles, citam-se: uso do solo; umidade da superfície; presença de fluxo; efeitos de degradação, entre outros. O autor evidencia que o mapa geoambiental é utilizado como uma ferramenta importante na avaliação de impactos ambientais.

Cendrero (1975) realizou o mapeamento geoambiental da Baía de Santander, localizada no norte da Espanha, onde foram mapeadas 53 unidades ambientais que posteriormente foram agrupadas em seis grandes sistemas ambientais. O autor definiu os sistemas através dos processos naturais, do relevo, das propriedades físicas e das intervenções humanas. Este trabalho contemplou apenas uma análise qualitativa, por isso o autor recomenda a realização de uma análise quantitativa para que o ordenamento territorial seja condizente com a capacidade de uso de cada uma das unidades, minimizando dessa forma os danos ambientais.

O mapeamento geoambiental da Polônia realizado pelo Instituto Geológico Polonês considerou uma escala de trabalho de 1:50.000. O mapa envolveu diversas categorias, dentre elas: recursos minerais; atividades minerárias; águas superficiais e subterrâneas; uso e cobertura do solo; áreas protegidas; disposição de resíduos; geoquímica; entre outras. Após a separação dos dados, a etapa posterior consistiu no processamento dos mesmos em um SIG, no qual foram codificados e editados conforme as técnicas de cartografia (SIKORSKAMAYKOWSKA; STRZELECK; LEWANDOWSKI, 2005).

Dal'Asta (2009) integrou vários elementos que constituem a paisagem do perímetro urbano de Santa Maria (RS), na escala de 1:50.000. Foram identificadas as unidades 
geoambientais considerando os atributos tanto naturais como antrópicos característicos. Os mapas temáticos utilizados para a realização do mapa geoambiental foram: mapa de uso e ocupação e cobertura vegetal; compartimentação geomorfológica; mapa de feições superficiais; mapa de unidades do relevo; mapa da rede hidrográfica e mapa geológico.

A metodologia utilizada por Dias, Tretin e Sccoti (2015) envolveu três fases iniciais: a base cartográfica; revisão bibliográfica e coleta de dados. Após estas etapas concentraram-se no trabalho de campo e geoprocessamento. Os atributos ambientais utilizados para a elaboração da carta geoambiental foram: declividade; unidades de relevo; hidrografia; litologia; morfolitologia; hipsometria; solos; e uso da terra.

Silveira et al. (2013) realizaram o mapeamento de áreas suscetíveis a ocorrência de processos geoambientais através do modelo digital do terreno. Os processos geoambientais analisados foram: escorregamentos, corridas de detritos e inundações associadas a corridas de lama na bacia do Rio Jacareí (PR). Para a elaboração do produto final (carta de suscetibilidade geoambiental) os autores utilizaram os seguintes atributos topográficos: hipsometria; declividade; plano de curvatura; e índice topográfico de umidade.

Conforme estabelece Rodrigues et al. (2015), para que o planejamento e a gestão das UCs aconteça de forma coerente e eficiente, é indispensável o mapeamento de unidades geoambientais. No trabalho dos autores foram identificadas e mapeadas as unidades geoambientais do Parque Estadual Caminho dos Gerais, localizado na porção sudeste do Brasil, com o objetivo de auxiliar de forma direta o planejamento ambiental da UC e a elaboração do PM. Para obtenção dos geoambientes, foram avaliados os aspectos da pedologia e geomorfologia, além das formações vegetais.

Calderano Filho et al. (2010) realizaram um estudo geoambiental para obter informações do meio físico e biótico para auxiliar o planejamento das áreas rurais da Serra dos Órgãos, utilizadas pela agricultura familiar. O trabalho envolveu técnicas de mapeamento digital, sensoriamento remoto, modelo digital do terreno e SIG. As etapas metodológicas compreenderam a elaboração de bancos de dados digitais em uma plataforma georreferenciada, além da obtenção de dados básicos de campo, por meio de mapeamentos temáticos dos atributos do meio físico, que foram agrupados com informações relacionadas à socioeconômia, a pluviosidade e áreas restritivas legalmente. Os resultados obtidos pelos autores contribuíram com a elaboração do PM conservacionista da área, pois a partir dos documentos produzidos foram caracterizados os aspectos do meio físico e ecológico da 
paisagem, favorecendo uma melhor compreensão das potencialidades e restrições dos recursos naturais.

Conforme Tretin e Robaina (2005), a realização do mapa geoambiental se inicia com estudos do substrato geológico e do levantamento de dados climáticos da área. Esse grupo de informações é considerado básico, devido o substrato rochoso e as condições climáticas antigas e atuais diferirem quanto à forma do relevo e as características da rede hidrográfica e do alterito resultante da desagregação e decomposição das rochas. A Figura 10 apresenta um fluxograma com as etapas para elaborar o mapa geoambiental.

Figura 10 - Níveis da elaboração do mapeamento geoambiental.

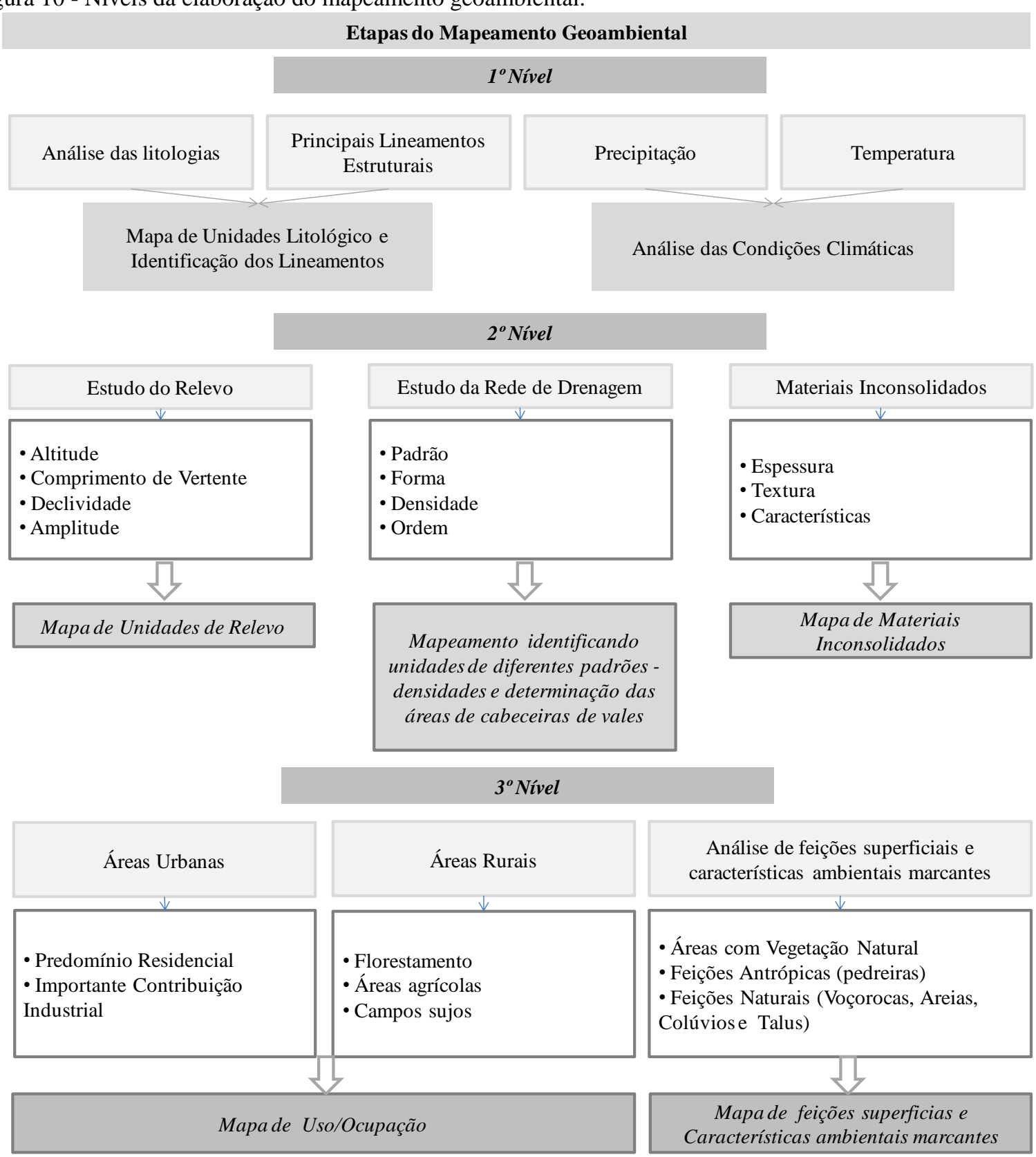

Fonte: Adaptado de Tretin e Robaina (2005). 
Para Zaikanov, Minakova e Buldakova (2015) a avaliação da condição geoambiental em escala regional é mais eficiente quando faz o uso da tecnologia de um SIG, devido a apresentar recursos que combinam o aspecto espacial e as informações com os fatores geoambientais. Considerando a escala regional, a estrutura das informações no SIG serve para resolver os problemas associados ao planejamento da área, visto que esta estrutura compreenderá três fases integradas, sendo elas: base de dados primários, estatísticos e regulamentares; fase de operações e transformação; e resultado final (mapa geoambiental).

Em um estudo de mapeamento geoambiental um dos problemas encontrados é a escolha dos níveis administrativos (federal, regional e municipal). No trabalho, os autores também expõem níveis nos sistemas de divisão administrativa e natural quanto à hierarquia espacial dos objetos de mapeamento. A Tabela 17 apresenta os quatro níveis que correspondem a um objeto individual do mapeamento geoambiental (ZAIKANOV; MINAKOVA; BULDAKOVA, 2014).

Tabela 17 - Níveis dos objetos de mapeamento geoambiental.

\begin{tabular}{|c|c|c|c|c|}
\hline \multirow{2}{*}{$\begin{array}{l}\text { Nível de divisão } \\
\text { administrativa }\end{array}$} & \multirow{2}{*}{$\begin{array}{c}\text { Nível de } \\
\text { mapeamento } \\
\text { geoambiental }\end{array}$} & \multirow{2}{*}{$\begin{array}{c}\text { Escala de } \\
\text { mapeamento }\end{array}$} & \multicolumn{2}{|c|}{ Objeto de mapeamento geoambiental } \\
\hline & & & Sistema natural & $\begin{array}{c}\text { Sistema } \\
\text { geoambiental }\end{array}$ \\
\hline Federal & Global & $\begin{array}{c}<1: \\
2.500 .000\end{array}$ & Província fisiográfica & $\begin{array}{c}\text { Província } \\
\text { geoambiental }\end{array}$ \\
\hline Entidade & Regional & $\begin{array}{l}1: 1.000 .000 \\
-1: 200.000\end{array}$ & $\begin{array}{l}\text { Região fisiográfica, } \\
\text { paisagem }\end{array}$ & $\begin{array}{c}\text { Distrito } \\
\text { geoambiental }\end{array}$ \\
\hline Distrito & Subregional & $\begin{array}{l}1: 100.000- \\
1: 50.000\end{array}$ & Paisagem, localização & $\begin{array}{c}\text { Zona } \\
\text { geoambiental }\end{array}$ \\
\hline Municipal & Local & $\begin{array}{l}1: 25.000- \\
1: 10.000\end{array}$ & Localização & $\begin{array}{c}\text { Área de Paisagem } \\
\text { urbana }\end{array}$ \\
\hline
\end{tabular}

Fonte: Adaptado de Zaikanov, Minakova e Buldakova (2014). 


\section{CaracterizaÇÃo da Área de eSTUdo}

A área de estudo está inserida na Bacia Hidrográfica dos Afluentes Mineiros do Médio Rio Grande (GD7), compreendendo uma das oito unidades de gerenciamento de recursos hídricos da Bacia Hidrográfica do Rio Grande situada no estado de Minas Gerais.

A Bacia Hidrográfica (GD7) localiza-se na porção sudoeste do Estado de Minas Gerais, apresenta uma área de aproximadamente de $9.800 \mathrm{~km}^{2}$ e engloba 22 municípios (Figura 11). Dentre eles, a área de estudo é o município de Delfinópolis. Este se situa no norte da bacia hidrográfica, no Chapadão da Canastra com uma área de abrangência de aproximadamente $1.379 \mathrm{~km}^{2}$. Limita-se com os municípios de Cássia, Ibiraci, Passos, Sacramento, São João Batista do Glória e São Roque de Minas, sendo que sua porção sul é totalmente margeada pelo Rio Grande.

Figura 11 - Localização do município de Delfinópolis (MG).

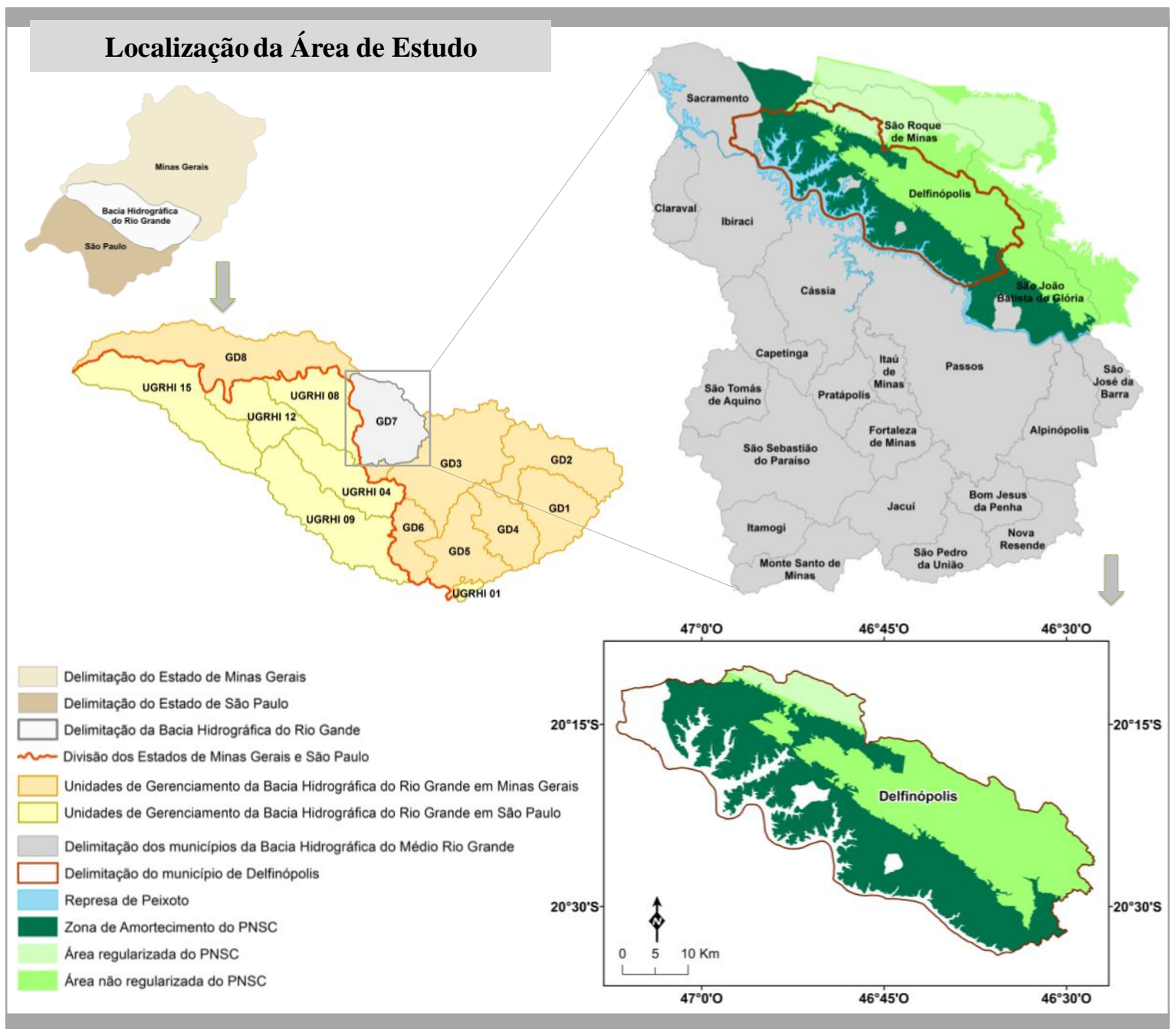


Nesta região está localizado parte do Parque Nacional da Serra da Canastra (PNSC), com uma área de 200.000 ha, sendo que somente 71.525 ha da área estão regularizados. Para o restante desta unidade de conservação não foi realizado nenhum processo de indenização, o que dificulta o gerenciamento do Parque, devido às atividades desenvolvidas nos seus limites internos (IBAMA, 2005).

A área de estudo dista 80,9 $\mathrm{km}$ da cidade de Passos (cidade polo da região), considerando o trajeto pela BR-464. Outra opção de acesso ao município de Delfinópolis saindo de Passos é pela rodovia MG-050 até Itaú de Minas, logo segue-se pela MG-344 até Cássia, em seguida percorre-se pela LMG-836 (Rodovia Dr. Rogério Antonio Pinto). Este segundo trajeto depende da travessia em balsa, após a embarcação percorre-se mais $25 \mathrm{~km}$ de estrada pavimentada. A Figura 12 apresenta o mapa das principais vias de acesso na região sudeste para a chegada ao município.

Figura 12 - Principais vias de acesso à área de estudo na região sudeste.

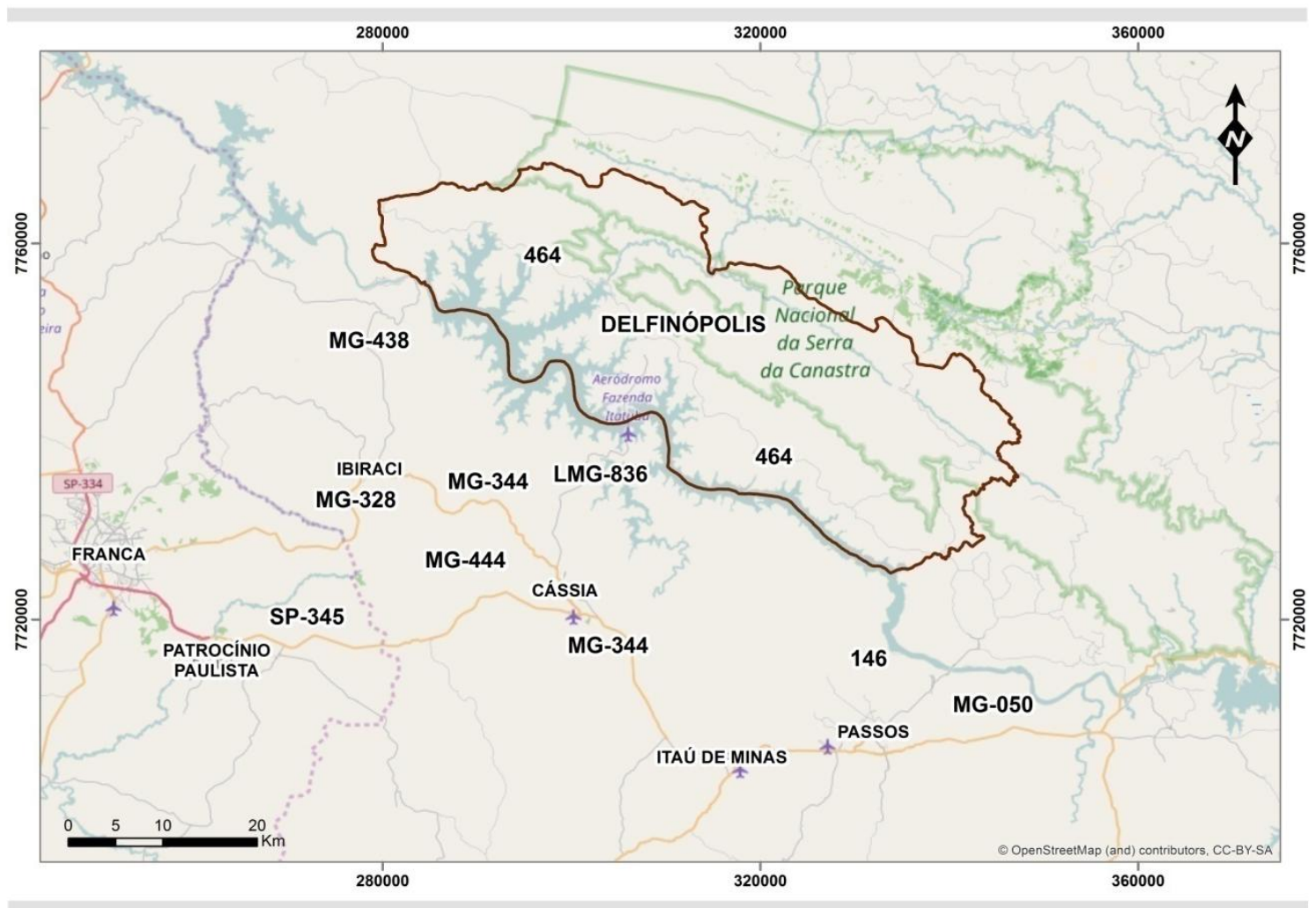

\subsection{Vegetação}

Segundo o IBGE (2016), o bioma predominante no município é o cerrado que corresponde $93 \%$ da área. Na região do Parque Nacional da Serra da Canastra as principais 
fitofisionomias encontradas são: as florestas mesófilas de encosta, capões, cerradão, cerrado, campo cerrado, campo limpo e campo rupestre (IBAMA, 2005).

De acordo com Novais (2011) o cerrado apresenta fisionomias que abrangem as formações florestais, savânicas e campestres. A floresta representa áreas onde predominam as espécies arbóreas, nas quais apresentam a formação de dossel, podendo ser contínuo ou descontínuo. Com relação às savanas, estas são caracterizadas por locais com árvores e arbustos distribuídos sobre um estrato graminoso, sem a ocorrência de um dossel contínuo. Com relação ao campo, são áreas com espécies herbáceas e também algumas arbustivas.

A Figura 13 apresenta o mapa da cobertura vegetal do município de Delfinópolis realizado no ano 2009, obtido na plataforma do Inventário Florestal de Minas Gerais. A Tabela 18 apresenta os dados quantitativos dos tipos de vegetação.

Figura 13 - Mapa da cobertura vegetal do ano de 2009.

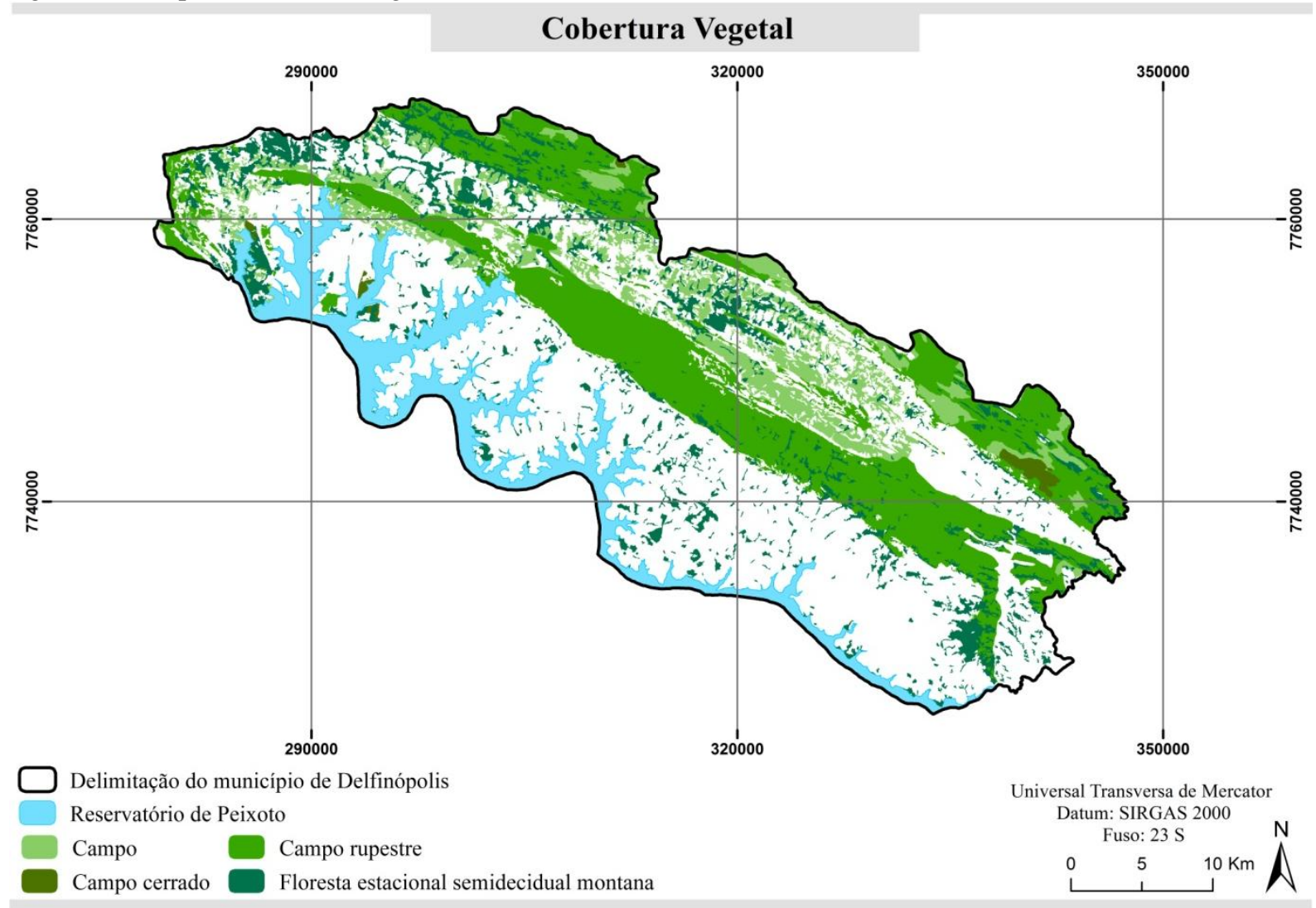

Fonte: Adaptado de Scolforo, Oliveira e Carvalho (2016). 
Tabela 18 - Área dos tipos de cobertura vegetal do município de Delfinópolis, no ano de 2009.

\begin{tabular}{c|c}
\hline \multicolumn{2}{c}{ Cobertura Vegetal } \\
\hline Classes & Área $\left(\mathbf{k m}^{\mathbf{2}}\right)$ \\
\hline Campo & 138,15 \\
\hline Campo Cerrado & 7,20 \\
\hline Campo Rupestre & 323,41 \\
\hline Floresta Estacional Semidecidual Montana & 138,34 \\
\hline
\end{tabular}

\subsection{Clima}

O clima é caracterizado por verão chuvoso e inverno seco. A temperatura média anual varia entre $22-23^{\circ} \mathrm{C}$, e precipitação média anual apresenta valores entre 1.200 e $1.800 \mathrm{~mm}$, concentrados principalmente na estação da primavera e verão (outubro a março) (IBAMA, 2005).

Conforme apresentado pelo Instituto Brasileiro de Desenvolvimento Florestal (IBDF) no ano de 1981, os dados hidroclimatológicos relacionados ao balanço hídrico para a região de Delfinópolis, indicam excedentes hídricos entre o período de outubro a março, porém o déficit hídrico ocorre nos meses de abril a setembro. O retorno de água no solo ocorre no início do período úmido (final de setembro e início de outubro). A estimativa dos dados do balanço hídrico representa uma evapotranspiração potencial anual de $1.012 \mathrm{~mm}$, com excedente hídrico correspondendo a 623 mm (IBAMA, 2005).

\subsection{Recursos Hídricos}

A Figura 14 apresenta os principais cursos d'água do município de Delfinópolis. Observa-se que toda parte sul do município é margeada pelo lago de Peixoto, sendo um dos reservatórios artificiais do Rio Grande, que se encontra no limite de duas usinas hidrelétricas administradas por Furnas Centrais Elétricas S.A: Furnas e Mascarenhas de Moraes.

A utilização dos recursos hídricos subterrâneos no município não é relevante, um dos motivos são as restrições legais impostas pela área da unidade de conservação de proteção integral, além disso, esta região apresenta atributos físicos que a caracteriza com baixa 
potencialidade hídrica. Os sistemas aquíferos presentes são: quartzítico; xistoso; gnáissicogranítico; e cobertura detrítica.

Figura 14 - Mapa dos cursos d'água principais do município de Delfinópolis (MG).

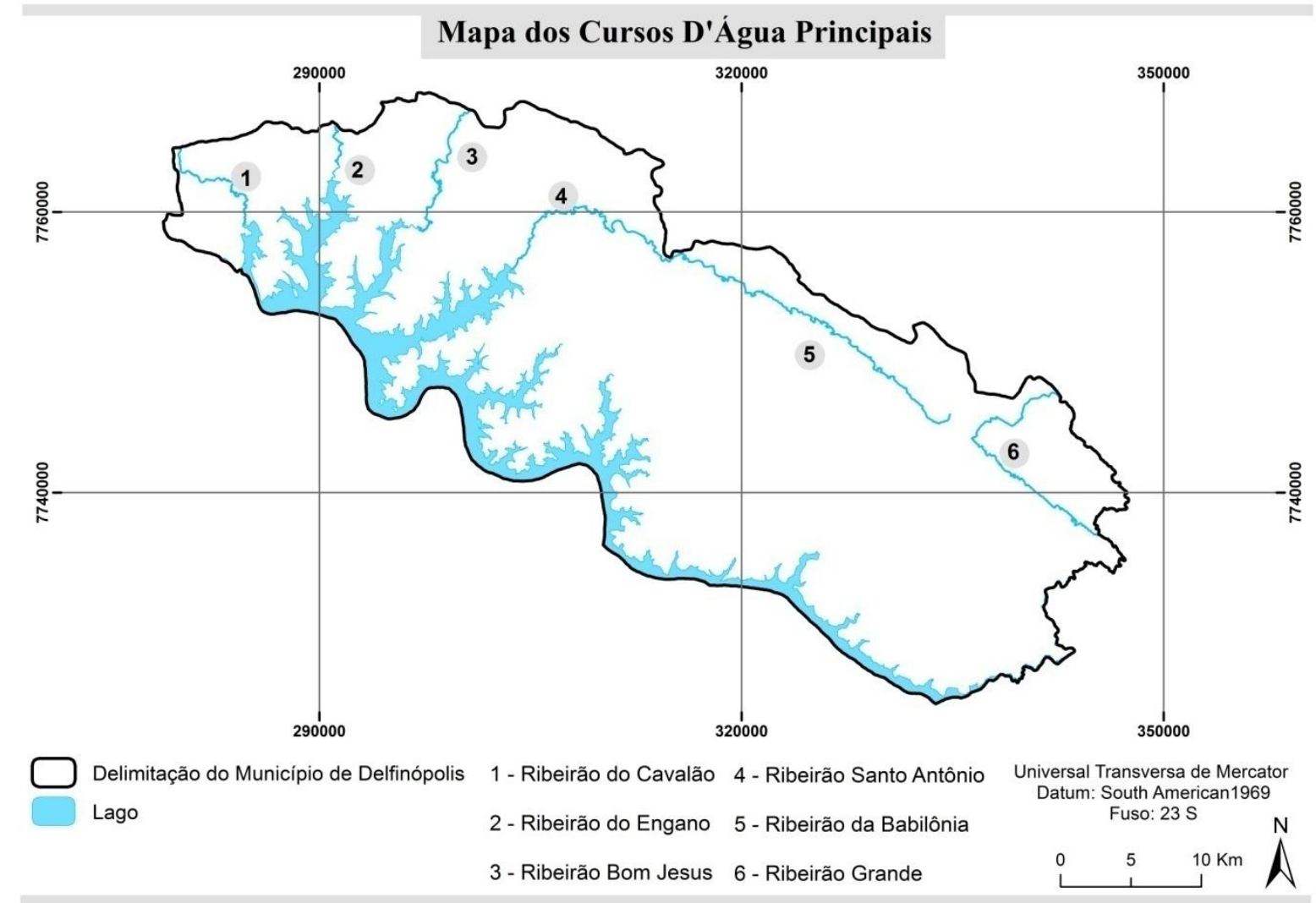

Fonte: Adaptado de Collares, Gomes e Santos (2013).

\subsection{Geologia e Geomorfologia}

A geologia da região do município de Delfinópolis confirma que sua história précambriana abrange o desenvolvimento de uma extensa bacia, a qual sofreu submissão de um processo de inversão, responsável pela deformação e metamorfismo. O município está situado na porção meridional da Faixa de Brasília, que é uma faixa de dobramentos oriunda do encontro de duas placas, conhecidas de San Franciscana, e a Placa Paraná (ALKIMIM et al. 1993 apud SOUSA, 2001).

Segundo Collares e Gomes (2013), a geologia está representada principalmente por rochas do Grupo Canastra (gnaisse, xisto e milonito) e Grupo Araxá (gnaisse, xisto e quartzito). O município apresenta três formações geológicas, para estas foram definidas onze unidades geológicas, conforme expostas na Tabela 19, com seus respectivos dados quantitativos. 
Tabela 19 - Classificação das unidades geológicas da área de estudo.

\begin{tabular}{|c|c|c|c|}
\hline \multirow{2}{*}{$\begin{array}{l}\text { Formações } \\
\text { Geológicas }\end{array}$} & \multirow{2}{*}{ Litologia (Unidades Geológicas) } & \multicolumn{2}{|c|}{ Área } \\
\hline & & $\mathbf{k m}^{2}$ & $\%$ \\
\hline $\begin{array}{l}\text { Coberturas } \\
\text { Aluvionares }\end{array}$ & Coberturas aluvionares & 15,85 & 1,27 \\
\hline \multirow{6}{*}{ Grupo Araxá } & $\begin{array}{l}\text { Gnaisses com intercalações de xisto, quartzo-xisto, } \\
\text { quartzito e anfibolito }\end{array}$ & \multirow{6}{*}{917,15} & \multirow{6}{*}{73,60} \\
\hline & Gnaisse com intercalações de xisto, quartzito e anfibolito & & \\
\hline & $\begin{array}{l}\text { Mica-xisto com ocorrências ocasionais de quartzito e } \\
\text { lentes de mármore }\end{array}$ & & \\
\hline & $\begin{array}{l}\text { Mica-xisto com intercalações de quartzo-xisto, quartzito, } \\
\text { anfibolito e gnaisse }\end{array}$ & & \\
\hline & Mica-xisto com intercalações comuns de quartzito & & \\
\hline & Quartzito com intercalações de mica-xisto & & \\
\hline \multirow{4}{*}{$\begin{array}{l}\text { Grupo } \\
\text { Canastra }\end{array}$} & $\begin{array}{l}\text { Milonito e localmente, gnaisses associados a rochas } \\
\text { ulramáficas }\end{array}$ & \multirow{4}{*}{313,10} & \multirow{4}{*}{25,13} \\
\hline & Filito com intercalações ocasionais de quartzito & & \\
\hline & $\begin{array}{l}\text { Quartzito com intercalações ocasionais de mica-xisto e } \\
\text { filito }\end{array}$ & & \\
\hline & $\begin{array}{l}\text { Mica-xisto com intercalações de quartzo-xisto e quartzito. } \\
\text { Ocasionalmente lentes de rochas metabásicas }\end{array}$ & & \\
\hline
\end{tabular}

Fonte: Adaptado de Collares e Gomes (2013).

As Figuras 15 e 16 apresentam respectivamente, os mapas geológico e geomorfológico que contemplam a área de estudo, sendo o primeiro elaborado pelo Centro Tecnológico de Minas Gerais (CETEC) e o segundo pelo Serviço Geológico do Brasil (CPRM), ambos na escala de 1: 1.000.000. 
Figura 15 - Mapa de geologia da área de estudo elaborado pelo CPRM.

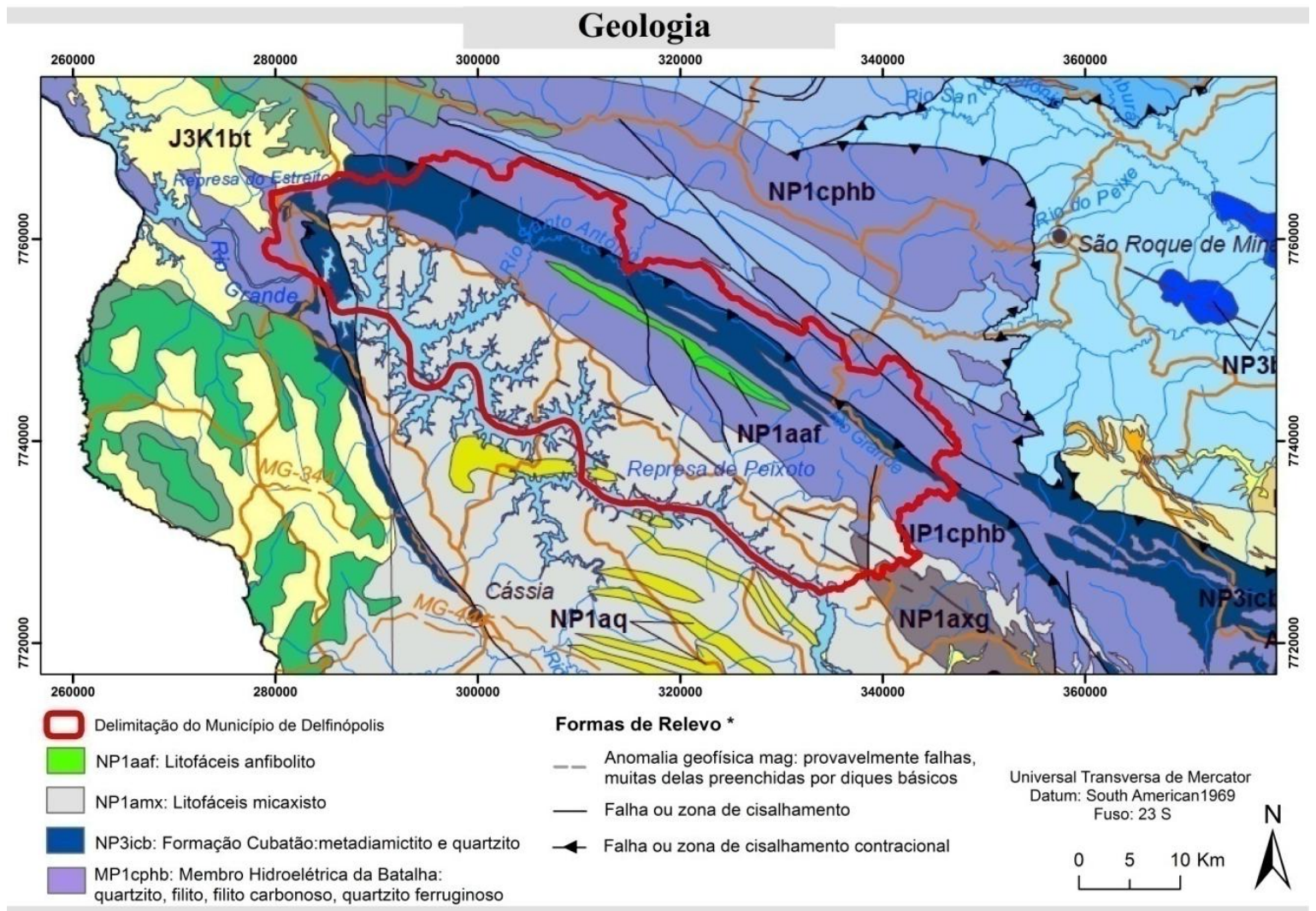

Fonte: Adaptado de CPRM (2014). * Legenda: somente as classes presentes na área de estudo.

Figura 16 - Mapa de geomorfologia da área de estudo elaborado pela CETEC.

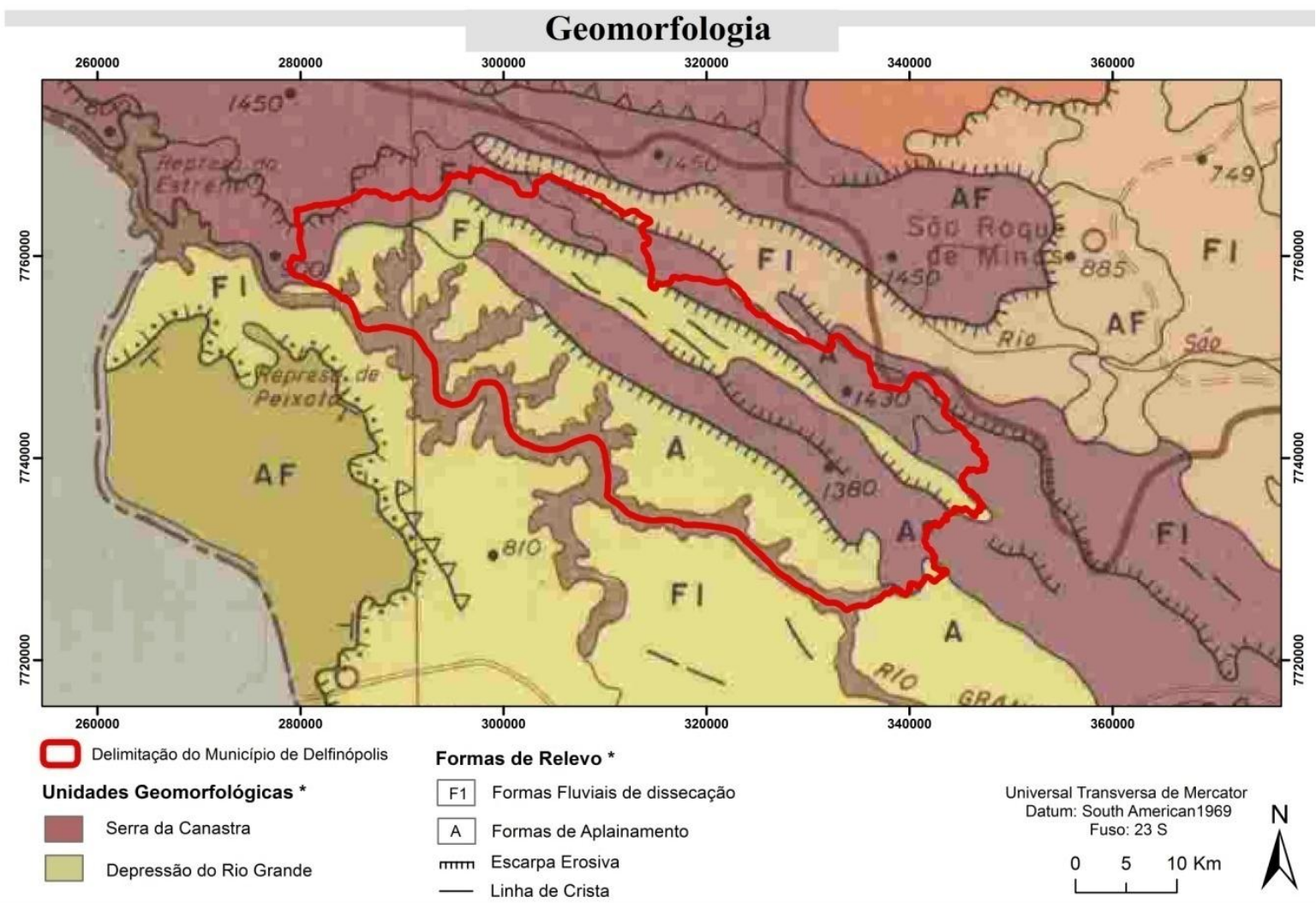

Fonte: Adaptado de CETEC (1981). * Legenda: somente as classes presentes na área de estudo. 
Segundo Magri (2013) o município apresenta oito unidades de relevo, sendo as serras e as colinas as classes mais expressivas. A Tabela 20 apresenta a distribuição em área $\left(\mathrm{Km}^{2} \mathrm{e}\right.$ $\%$ ) das classes do mapa de lanforms elaborado por Magri (2013).

Tabela 20 - Área das classes do mapa de landforms no município de Delfinópolis.

\begin{tabular}{c|c|c}
\hline \multirow{2}{*}{ Classes } & \multicolumn{2}{|c}{ Área } \\
\cline { 2 - 3 } & $\mathbf{K m}^{\mathbf{2}}$ & $\mathbf{\%}$ \\
\hline Colinas & 435,64 & 34,95 \\
\hline Escarpas & 9,16 & 0,74 \\
\hline Morros & 137,96 & 11,07 \\
\hline Morrotes & 22,05 & 1,77 \\
\hline Planícies & 31,14 & 2,50 \\
\hline Platôs & 2,11 & 0,17 \\
\hline Serras & 548,84 & 44,04 \\
\hline Vales & 59,32 & 4,76 \\
\hline
\end{tabular}

A região do município em que o relevo é composto por serras, o material inconsolidado predominante apresenta textura arenosa. Nas regiões em que o relevo é colinoso, a fração areia também é dominante. Com base no mapa de solos elaborado pela CETEC (1981), na escala de 1:1.000.000, o município apresenta dois tipos de solos, sendo eles: litólicos (na porção norte) e latossolo vermelho amarelo (na porção sul).

\subsection{Socioeconomia}

O município de Delfinópolis apresenta uma população de 6.830 habitantes, sendo que $71 \%$ deste contingente residem na zona urbana (IBGE, 2010). Com relação ao desenvolvimento do município, com base no ano de 2013, o sistema FIRJAN (Federação das Indústrias do Estado do Rio de Janeiro) indica que o município apresenta um índice de desenvolvimento socioeconômico de 0,7609, lembrando que este indicador é realizado com base em análises estatísticas de três setores (emprego e renda; educação e saúde). Para este valor, o município é classificado com um desenvolvimento moderado ( 0,6 a 0,8 pontos) (FIRJAN, 2015).

A economia do município de Delfinópolis está embasada no setor da agricultura, com o cultivo de cana-de-açúcar, soja e banana. Destaca-se como o quarto dentre os outros 
municípios da Bacia Hidrográfica GD7 na produção de cana-de-açúcar e o terceiro no cultivo de soja, correspondendo respectivamente a 3.000 ha e 6.800 ha (IBGE, 2014).

O setor minerário se apresenta de forma bastante expressiva, principalmente com as extrações de quartzito, devido o número de minerações a céu aberto, como também pelos impactos indesejáveis ao meio físico, sendo que quase todas as minerações existentes na área apresentam impedimentos por órgãos ambientais responsáveis (ALMEIDA, 2014).

Além da agricultura e das atividades minerárias, outro setor que contribui fortemente com esta categoria é o turismo, pois a região apresenta grandes belezas cênicas. Segundo Sousa (2001), nas serras situam-se as principais atrações turísticas do município, que são cachoeiras e trilhas, sendo também o local de práticas esportivas como: ciclismo, rallys, motociclismo, trekking, rappel, cnayoning e outros. 



\section{Materiais e métodos}

\subsection{Materiais}

As imagens de satélite, os produtos cartográficos existentes e os softwares utilizados nos processamentos desta pesquisa são apresentados a seguir:

a-) Imagens de satélite

- 40 Imagens do Google ${ }^{\mathrm{TM}}$ Earth Pro disponibilizadas pela CNES/Astrium, visto que cada região do município apresenta imagens com datas diferentes, referente aos anos de 2012, 2014 e 2016.

b-) Produtos cartográficos existentes

- Mapas temáticos elaborados pela equipe do Projeto Grande Minas que realizou o Zoneamento Ambiental das Sub-Bacias Hidrográficas dos Afluentes Mineiros do Médio Rio Grande, na escala de 1:50.000.

- Bacias hidrográficas de $1^{\mathrm{a}}, 2^{\mathrm{a}}, 3^{\mathrm{a}}$ e $4^{\mathrm{a}}$ ordem (COLLARES; GOMES; SANTOS, 2013);

- Rede de drenagem (COLLARES; GOMES; SANTOS, 2013);

- Curvas de nível com equidistância de 20 metros e pontos cotados (MAGRI, 2013);

- Mapa de materiais inconsolidados (MAGRI, 2013);

- Mapa de landforms (MAGRI, 2013);

- Mapa de substrato rochoso (COLLARES; GOMES, 2013);

- Mapa de sistemas aquíferos (COLLARES; GOMES, 2013);

- Mapa do uso e ocupação do solo (DIAS, 2013).

- Documentos cartográficos interpretativos

- Carta de potencialidade à produção rural (SANTOS et al., 2013);

- Carta de suscetibilidade à erosão (MAGRI, 2013); 
- Carta de escoamento superficial (MAGRI, 2010);

- Carta de capacidade de infiltração (COLLARES et al., 2013);

- Carta de suscetibilidade à inundação (SANTOS; COLLARES; COLLARES, 2013).

c-) Documentos legislativos

- Plano de Manejo do Parque Nacional da Serra da Canastra - Volume I e II, elaborado pelo IBAMA (2005).

- Plano Diretor de Desenvolvimento Participativo do município de Delfinópolis, revisado no ano de 2014.

d-) Softwares

O software utilizado para o processamento dos planos de informação foi o Arc GIS $10.0^{\circledR}$ da ESRI. A tabulação e preparação dos valores de percentual de área dos atributos considerados neste trabalho para as análises estatísticas foram realizadas no software Excel ${ }^{\circledR}$ da Microsoft. O processo de análise de agrupamentos das bacias hidrográficas foi realizado no Statistica $13^{\circledR}$.

\subsection{Aspectos Metodológicos}

As principais etapas desenvolvidas neste trabalho são apresentadas no fluxograma da Figura 17. Os produtos cartográficos que foram utilizados para as análises específicas apresentam-se na escala 1:50.000, bem como os documentos cartográficos elaborados neste trabalho.

No fluxograma as etapas em laranja são consideradas as análises finais específicas que envolveram a análise das características físicas e ambientais que subsidiou a proposição das recomendações para cada unidade geoambiental. 

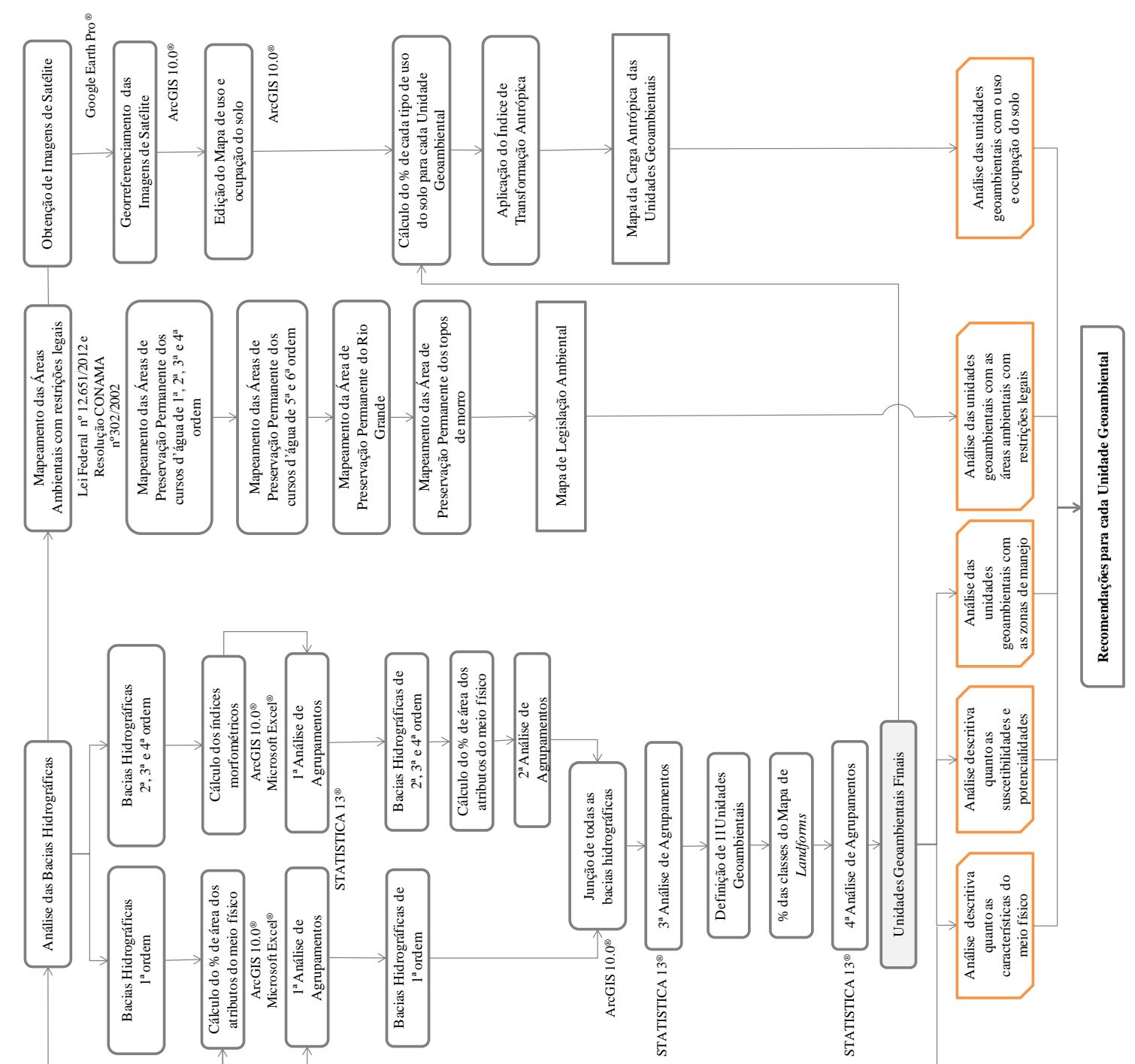

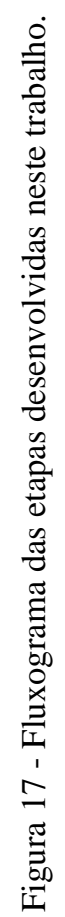




\subsubsection{Tratamento dos dados da área de estudo em um sistema georreferenciado}

\subsubsection{Preparação dos planos de informação para a área de estudo}

Os planos de informação do meio físico utilizados neste trabalho foram disponibilizados pelo Projeto Grande Minas que realizou o Zoneamento Ambiental dos Afluentes Mineiros do Médio Rio Grande, na escala de 1:50.000.

Como o Zoneamento Ambiental da Bacia Hidrográfica do Médio Rio Grande (GD7) envolveu produtos cartográficos para a área de toda unidade de planejamento, foi necessário à adaptação dos planos de informação para abranger somente a área do município em estudo. Os planos de informação temáticos utilizados foram: substrato rochoso; materiais inconsolidados; sistemas aquíferos; unidades de relevo (landforms); e uso e ocupação do solo.

Além da adaptação dos mapas temáticos foram também tratados os planos de informação das cartas interpretativas, sendo que estes produtos também foram elaborados na mesma escala deste trabalho. Os produtos interpretativos utilizados foram: suscetibilidade à erosão; suscetibilidade à inundação; aptidão agrícola; potencialidade à produção rural; escoamento superficial e capacidade de infiltração. Vale ressaltar que estes foram disponibilizados por alguns autores, conforme especificado no item 4.1.

O procedimento para a adaptação dos planos de informação foi realizado utilizando os seguintes comandos do software Arc GIS 10.0 ${ }^{\circledR}$ : Geoprocessing - Clip. Logo após, foi elaborado um banco de dados exclusivo do município, o que facilitou a realização das análises posteriores.

Estes dois tipos de produtos cartográficos (temáticos e interpretativos) foram utilizados para o estabelecimento e descrição das unidades geoambientais da área em estudo.

\subsubsection{Obtenção de imagens de satélite e georreferenciamento}

As imagens de satélite foram obtidas através do programa Google Earth Pro ${ }^{\circledR}$, as quais foram salvas em resolução máxima.

Em um primeiro momento foi estabelecida uma malha de coordenadas sobre a área de estudo, logo foram extraídos os pontos de referência para a captura das imagens, que foram 
transformados do formato $\mathrm{sh}$. para o formato $\mathrm{kml}$., este procedimento dependeu dos seguintes comandos do Arc GIS 10.0 ${ }^{\circledR}$ : Arc Toolbox - Conversion Tools - To KML - Layer to KML.

Após a transformação dos pontos de referência, estes foram inseridos no Google Earth Pro $^{\circledR}$, a partir de então foi necessária à aquisição de 40 imagens para contemplar todo o município. Logo, as imagens foram inseridas e georreferenciadas no software Arc GIS 10.0 ${ }^{\circledR}$, por meio da ferramenta Georeferencing - Uptade Georeferencing.

Vale ressaltar que, cada porção do município apresenta imagens obtidas em anos diferentes. A Figura 18 apresenta a espacialização destas imagens na área de estudo, bem como suas respectivas datas.

A Figura 19 apresenta o mosaico das imagens adquiridas após a etapa do georreferenciamento. A aquisição das imagens de satélite foi necessária para a atualização do mapa de uso e ocupação do solo elaborado na escala de 1:50.000 por Dias (2013).

Figura 18 - Espacialização dos pontos de referência e as datas das respectivas imagens.

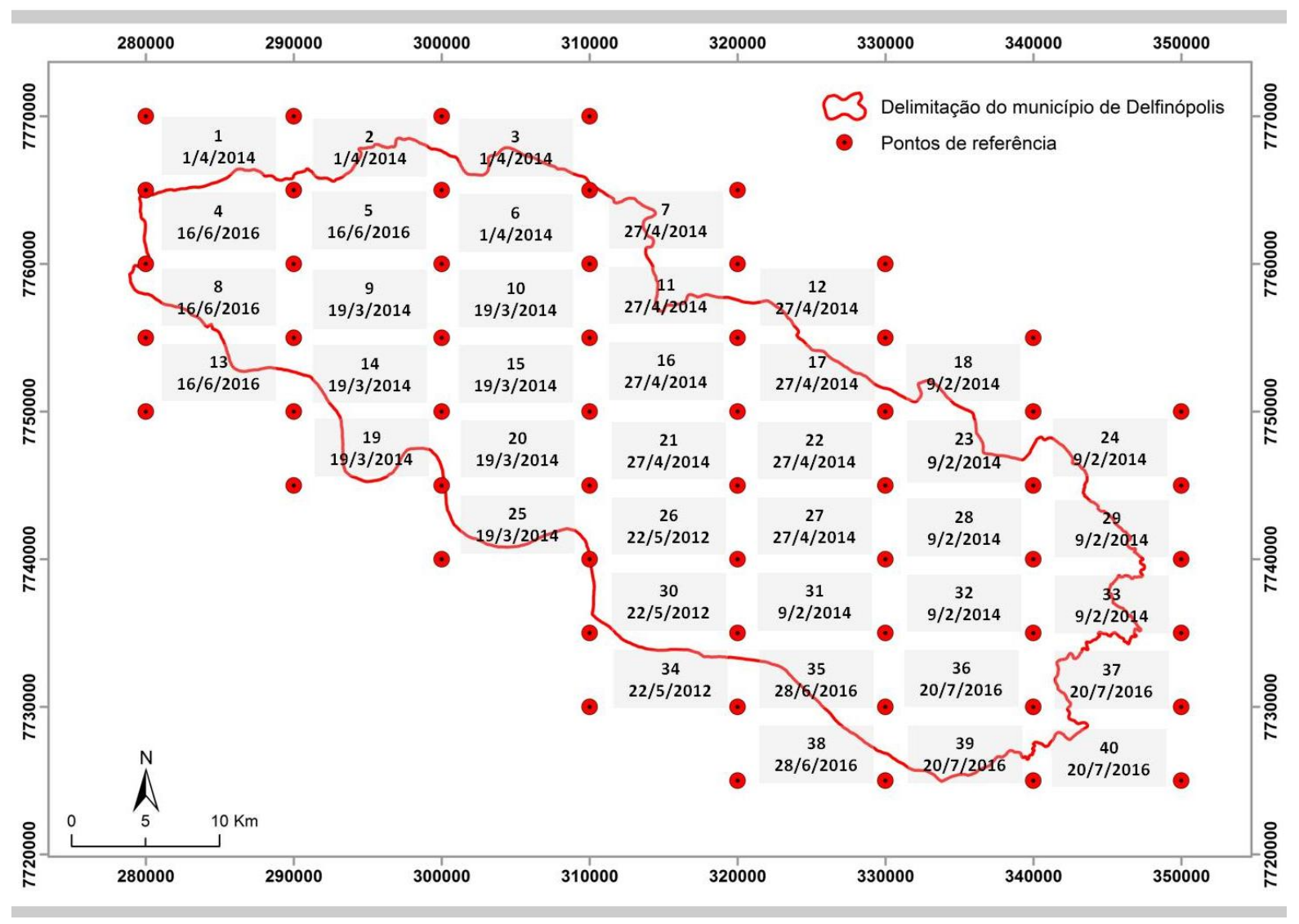


Figura 19 - Mosaico das imagens de satélite que contemplam o município de Delfinópolis (MG).

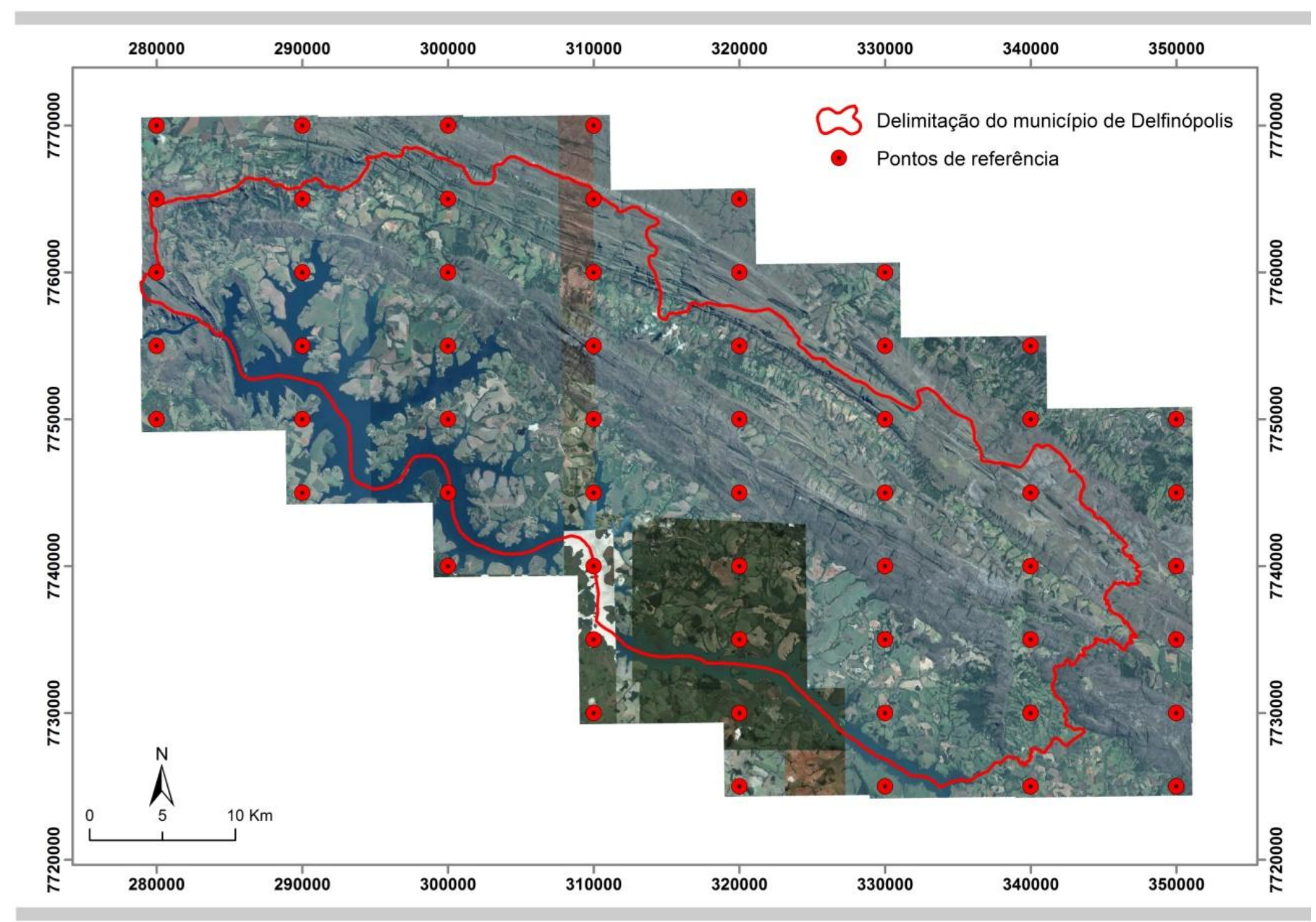




\subsubsection{Elaboração do Modelo Digital de Elevação Hidrologicamente Consistente (MDEHC) e da Carta de Declividades}

O MDEHC da área de estudo foi realizado com base nas curvas de nível com equidistância de 20 metros, nos pontos cotados, na rede de drenagem e na delimitação da represa do Rio Grande, estes planos de informação foram interpolados por meio do procedimento operacional da ferramenta Topo to Raster presente no software Arc GIS $10.0^{\circledR}$.

Segundo Carmo (2014) a ferramenta topo to raster foi baseada nos trabalhos elaborados por Hutchinson na década de 80, em seu programa ANUDEM. O sucesso dessa técnica se dá por possibilitar a utilização de outros tipos de arquivos sem ser os pontos, como as curvas de nível, as linhas e polígonos que representam respectivamente os rios e lagos, além das delimitações de bacias. Estes arquivos diminuem os erros que podem ser encontrados após o processo de interpolação.

Vale ressaltar que os dados de entrada foram elaborados na escala de 1:50.000 e que o tamanho do pixel de saída utilizado foi de 10 metros. A Figura 20 apresenta os planos de informações utilizados.

Figura 20 - Planos de informação utilizados para a elaboração do MDEHC.

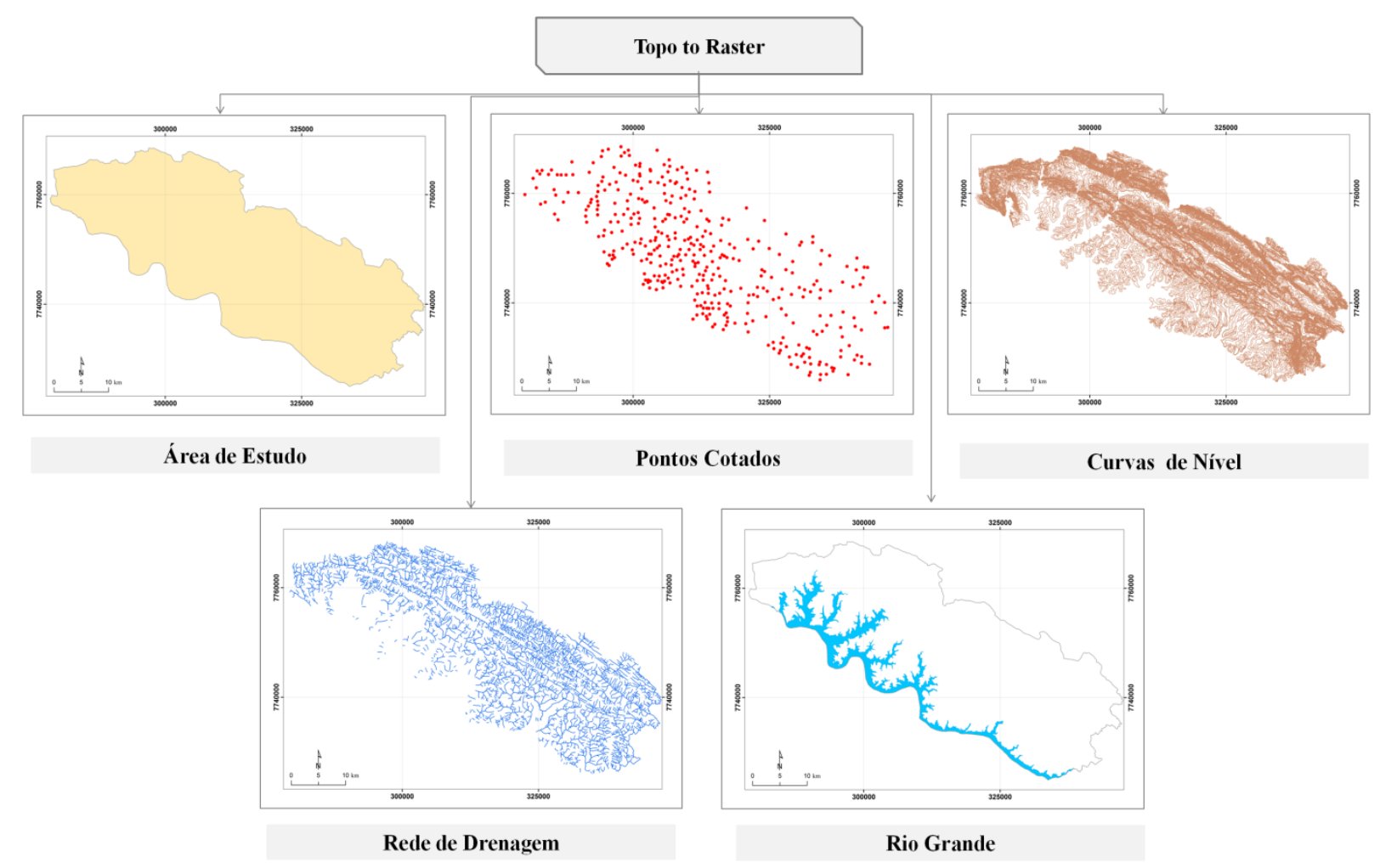


Após a realização desta etapa, no modelo foi aplicado um filtro para suavizar os efeitos oriundos do processo de interpolação. Este procedimento foi realizado pelos seguintes comandos: Arc Toolbox - Spatial Analyst Tools - Hidrology - Fill.

Para a validação da qualidade do modelo produzido foram elaboradas as curvas de nível a partir do próprio MDEHC. Dessa forma, a avaliação do modelo consistiu na comparação destas novas curvas de nível com o plano de informação utilizado no início da execução do modelo. As novas curvas de nível também foram elaboradas no software Arc GIS $10.0^{\circledR}$, para tal utilizou-se o comando Countour Interval, encontrado na extensão Spatial Analyst.

O MDEHC foi utilizado como arquivo matricial para a elaboração da Carta de Declividades, os comandos empregados do Arc GIS 10.0 ${ }^{\circledR}$ foram: Spatial Analyst Tools Surface - Slope.

Após a elaboração da Carta de Declividades, esta foi classificada em oito classes, sendo: $0-2 \% ; 2-5 \% ; 5-10 \% ; 10-15 \% ; 15-20 \% ; 20-30 \% ; 30-45 \%$; e > 45\%. Esta classificação foi utilizada para a quantificação de cada classe dentro de todas as bacias hidrográficas de $1^{\mathbf{a}}$, $2^{\mathrm{a}}, 3^{\mathrm{a}}$ e $4^{\mathrm{a}}$ ordem presentes no município.

Além disso, o MDEHC também foi utilizado para o mapeamento das áreas de preservação permanente dos topos de morro do município, tal procedimento se encontra explicado com mais detalhes no item 4.2.6.2.

\subsubsection{Procedimentos para o estabelecimento das unidades geoambientais na área de estudo}

Para a definição das unidades geoambientais do município de Delfinópolis (MG) foi proposta uma metodologia com base nos padrões de morfometria das bacias hidrográficas da área em estudo. Para o estabelecimento das unidades foram realizadas análises estatísticas com a intenção de unir as bacias hidrográficas que apresentam características físicas semelhantes, para isto foi utilizada a análise de agrupamentos, também conhecida como cluster analysis. A Figura 21 apresenta sinteticamente os procedimentos realizados para a obtenção das unidades geoambientais. 
Figura 21 - Etapas para a definição das unidades geoambientais da área de estudo.

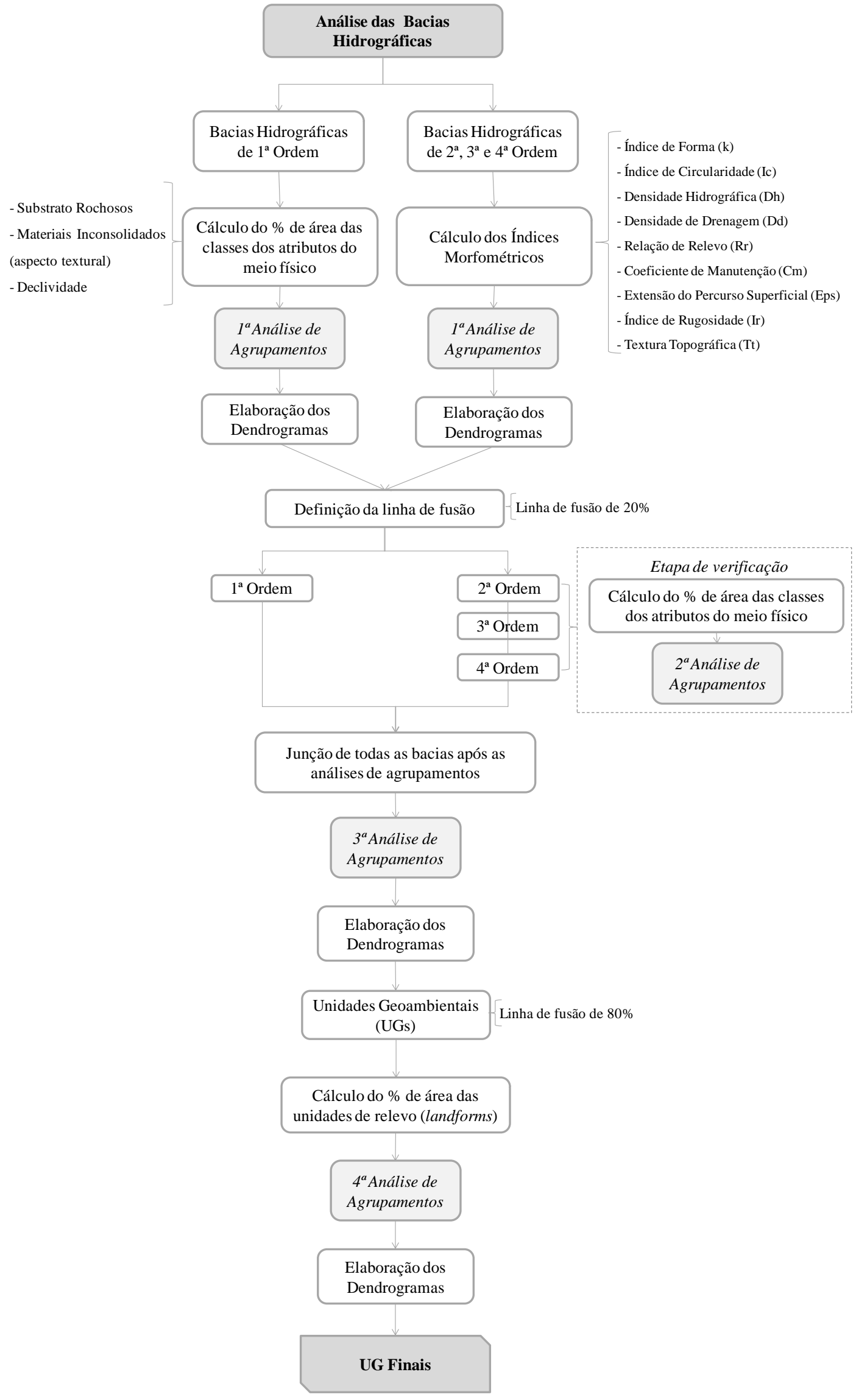


Como a área de estudo trata-se de um limite administrativo e não de um limite fisiográfico foi necessário, em primeiro momento, definir as unidades de planejamento dentro do município. Dessa forma, foram utilizadas as bacias hidrográficas de $1^{\mathrm{a}}, 2^{\mathrm{a}}, 3^{\mathrm{a}}$ e $4^{\mathrm{a}}$ ordem que abrangem totalmente a área de estudo, visto que estas foram delimitadas na escala de 1:50.000 por Collares; Gomes e Santos (2013), seguindo o conceito de Strahler (1957). Vale ressaltar que existem três drenagens que drenam para dentro do município, porém estes rios não influenciaram nos resultados da análise estatística, pois neste trabalho foram consideradas bacias hidrográficas até a $4^{\mathrm{a}}$ ordem de ramificação.

O município de Delfinópolis foi compartimentado em 248 bacias hidrográficas, considerando bacias de $1^{\mathrm{a}}$ até $4^{\mathrm{a}}$ ordem de ramificação. As análises das bacias hidrográficas de $1^{\text {a }}$ ordem diferiram da análise das demais bacias, pelo motivo destas primeiras não apresentarem um valor de densidade de drenagem como das outras unidades, o que consequentemente refletiria nos cálculos dos outros índices morfométricos considerados neste trabalho que necessitam desta variável. Desse modo, preferiu-se realizar a análise das bacias de $1^{\mathrm{a}}$ ordem através do percentual de área das classes de três atributos do meio físico (materiais inconsolidados, substrato rochoso e declividade).

Os tópicos a seguir correspondem à descrição detalhada das etapas realizadas para o mapeamento das unidades geoambientais da área de estudo.

\subsubsection{Caracterização física das bacias hidrográficas de $1^{\text {a }}$ ordem}

Para caracterizar fisicamente as bacias hidrográficas de $1^{\mathrm{a}}$ ordem foi calculado o percentual de área das classes de três atributos do meio físico, sendo eles: substrato rochoso; materiais inconsolidados (apenas aspecto de granulometria); e declividade. A Tabela 21 apresenta a distribuição de classes destes atributos.

Para a efetivação desta etapa foi necessário utilizar o software Arc GIS $10.0^{\circledR}$ para o cálculo da área das bacias, bem como a área de cada classe dos atributos analisados. Vale ressaltar, que os planos de informação do meio físico foram elaborados na escala de 1:50.000 e disponibilizados pelo Projeto Grande Minas, os quais foram ajustados para a área de estudo, como descrito no item 4.2.1.1. 
Tabela 21 - Classes dos atributos do meio físico adotados nas análises das bacias hidrográficas de $1^{\mathrm{a}}$ ordem.

\begin{tabular}{c|c|c}
\hline \multicolumn{2}{c}{ Atributos do Meio Físico } \\
\hline Substrato Rochoso & $\begin{array}{c}\text { Materiais Inconsolidados } \\
\text { (apenas aspecto textural) }\end{array}$ & Declividade \\
\hline Coberturas Quaternárias & Areia & $0-2 \%$ \\
Gnaisse & Silte & $2-5 \%$ \\
Xisto & Silte e Rocha & $5-10 \%$ \\
Quartzito & Distribuída de Areia* & $10-15 \%$ \\
Milonito & Distribuída de Silte* & $15-20 \%$ \\
Xisto/Quartzito & Distribuída de Silte e Argila* & $20-30 \%$ \\
& Distribuída de Argila, Silte e Areia* & $30-45 \%$ \\
\hline
\end{tabular}

* "Distribuída" significa que estas classes caracterizam áreas que apresentam maior percentual de uma ou duas partículas e/ou as três frações granulométricas (argila, silte e areia) encontram-se dispostas em porcentagem muito parecidas.

O percentual de área de cada classe dos atributos analisados foram tabulados e organizados em planilha do Excel. Este procedimento foi necessário para análise das bacias quanto ao nível de similaridade com relação aos aspectos do meio físico, como também para a análise descritiva das unidades geoambientais, conforme citado no item 4.2.4.

\subsubsection{Caracterização morfométrica das bacias hidrográficas de $2^{\mathrm{a}}, 3^{\mathrm{a}}$ e $4^{\mathrm{a}}$ ordem}

As bacias hidrográficas de $2^{\mathrm{a}}, 3^{\mathrm{a}}$ e $4^{\mathrm{a}}$ ordem foram analisadas inicialmente através de seus padrões de morfometria. Nesta etapa foi utilizado o software Arc GIS $10.0^{\circledR}$ para obter o comprimento total dos canais de drenagem, o comprimento do canal principal, a amplitude máxima e mínima, bem como a área e o perímetro das bacias.

A escolha dos índices morfométricos a serem calculados foi baseada em envolver as variáveis que estão associadas aos três tipos de análises (linear, areal e hipsométrica) sugeridas por Christofoletti (1980), pois estas análises complementam uma a outra representando melhor o relevo e os processos naturais existentes nas bacias hidrográficas. Após a seleção dos índices, estes foram calculados individualmente respeitando as ordens das bacias $\left(2^{\mathrm{a}}, 3^{\mathrm{a}}\right.$ e $4^{\mathrm{a}}$ ordem $)$.

Os valores dos índices foram tabulados em planilha do Excel, visto que esses dados numéricos foram organizados em planilhas separadas considerando a hierarquia das bacias. Posteriormente, estas planilhas serviram para a realização da análise de agrupamentos destas 
unidades. Vale ressaltar que o número dos índices considerados foi suficiente para a realização da análise estatística. A Tabela 22 apresenta os índices que foram calculados.

Tabela 22 - Índices morfométricos calculados para as bacias hidrográficas de $2^{\mathrm{a}}, 3^{\mathrm{a}}$ e $4^{\mathrm{a}}$ ordem.

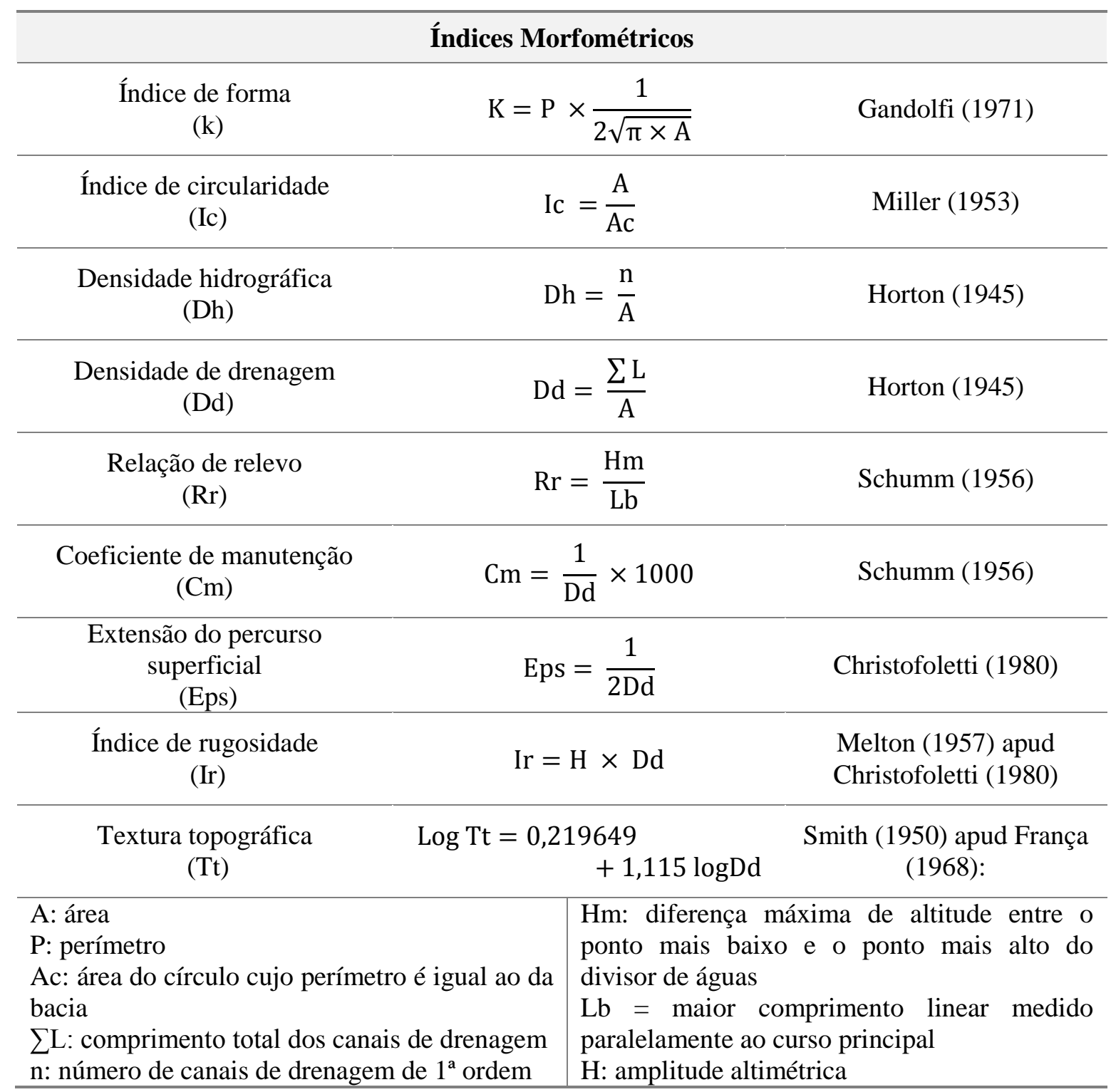

\subsubsection{Análise de agrupamentos das bacias hidrográficas}

Após o cálculo do percentual de área dos atributos do meio físico das bacias hidrográficas de $1^{\mathrm{a}}$ ordem e o cálculo dos nove índices morfométricos das bacias de $2^{\mathrm{a}}, 3^{\mathrm{a}}$ e $4^{\mathrm{a}}$ ordem, a planilha de dados foi inserida no software Statistica $13^{\circledR}$ para o início das análises de agrupamentos, visto que este trabalho realizou quatro etapas de agrupamentos conforme mostra a Figura 22. 
Figura 22 - Etapas de agrupamentos das bacias hidrográficas da área de estudo.

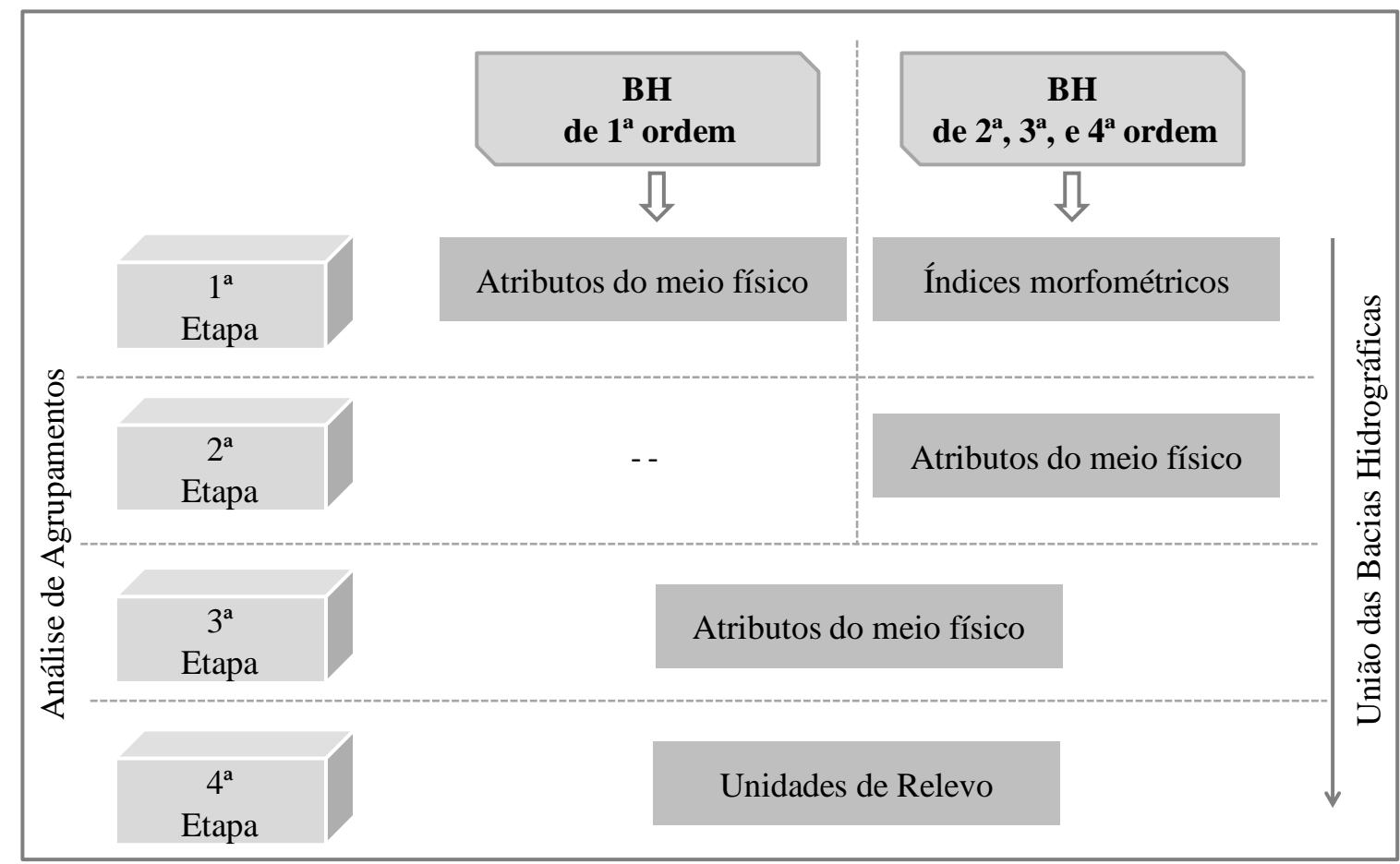

A primeira etapa da análise de agrupamentos foi realizada tanto para as bacias hidrográficas de $1^{\mathrm{a}}$ ordem, como para as demais ordens de bacias, com o objetivo de identificar similaridades, de maneira a uni-las o máximo possível. Vale ressaltar que inicialmente esta análise foi realizada separadamente, considerando as ordens de ramificação das bacias.

Com relação à segunda etapa, esta consistiu na análise dos atributos do meio físico das bacias hidrográficas de $2^{\mathrm{a}}, 3^{\mathrm{a}}$ e $4^{\mathrm{a}}$ ordem, com a finalidade de verificar se o agrupamento realizado com base nos parâmetros morfométricos se traduziu na maior homogeneidade das unidades delimitadas com relação a esses atributos.

A terceira etapa de agrupamentos envolveu todas as ordens de bacias, sendo consideradas as bacias após as duas fases citadas anteriormente. Esta fase envolveu a análise apenas do percentual de área dos atributos do meio físico, desse modo, a partir desta penúltima análise de agrupamentos foram estabelecidas as delimitações de onze unidades geoambientais.

Com a intenção de verificar a relação destas onze unidades geoambientais com as formas de relevo presentes na área de estudo, optou-se, portanto, em realizar a última análise de agrupamentos, além disso, esta última etapa foi realizada também com a finalidade de unir 
pequenos grupos de unidades criados depois das três primeiras etapas. No entanto, a quarta etapa consistiu na análise das onze unidades geoambientais quanto ao percentual de área das classes do mapa de landforms (elaborado por MAGRI, 2013).

Para realização destas análises, este trabalho fez uso de um método hierárquico, sendo o pareado igualmente ponderado, que segundo Landim (2011) se destaca quando analisa dados geológicos multivariados. Com relação ao critério de similaridade optou-se pelo coeficiente de distância, que de acordo com este autor apresenta um melhor resultado de agrupamento, com relação à medida de distância, a adotada foi à euclidiana. A técnica de agrupamento e a medida de distância utilizada foram às mesmas para a análise das bacias de $1^{\mathrm{a}}$ ordem, como também para o restante das bacias.

Posterior às análises de agrupamentos, foram elaborados os dendrogramas para cada uma das ordens das bacias $\left(1^{\mathrm{a}}, 2^{\mathrm{a}}, 3^{\mathrm{a}}\right.$ e $4^{\mathrm{a}}$ ordem), com a intenção de identificar os grupos de bacias que apresentaram um alto nível de similaridade.

Após a elaboração dos dendrogramas os grupos formados foram analisados para o estabelecimento da linha de fusão, também conhecida como linha de corte, a qual foi definida considerando a finalidade de estudo e o conhecimento dos dados analisados. A Tabela 23 apresenta a linha de fusão adotada para as quatro etapas de agrupamentos. Vale lembrar, que quanto mais próximo de $100 \%$ a linha for definida, maior será o nível de dissimilaridade.

Tabela 23 - Linha de fusão adotada para cada etapa da análise de agrupamentos.

\begin{tabular}{c|c}
\hline Etapas de Agrupamentos & Linha de Fusão \\
\hline $1^{\mathrm{a}}$ Etapa & Nível de homogeneidade de 20\% \\
\hline $2^{\mathrm{a}}$ Etapa & Nível de homogeneidade de 20\% \\
\hline $3^{\mathrm{a}}$ Etapa & Nível de homogeneidade de $80 \%$ \\
\hline $4^{\mathrm{a}}$ Etapa & Nível de homogeneidade de $20 \%$ \\
\hline
\end{tabular}

\subsubsection{Estabelecimento das unidades geoambientais}

Como mencionado nos itens anteriores, à área do município de Delfinópolis (MG) foi analisada considerando as suas características físicas. A partir desta análise, foi possível identificar as áreas mais homogêneas quanto aos atributos analisados, o que possibilitou o mapeamento das unidades geoambientais. 
Para o estabelecimento das unidades geoambientais foram calculados o percentual de área dos materiais inconsolidados (textura), substrato rochoso e declividade das 125 bacias hidrográficas agrupadas após as duas primeiras análises de agrupamentos. Estes cálculos foram efetuados no software Arc GIS $10.0^{\circledR}$ e tabulados em planilha no formato $x l s$ no programa Excel.

Após este procedimento, a planilha de dados das 125 bacias foi inserida no software Statistica $13^{\circledR}$ para a realização da terceira análise de agrupamentos. Logo, foi elaborado o dendrograma, no qual foi definida a linha de fusão no nível de homogeneidade de $80 \%$ para identificar dentre as unidades, aquelas que se encontram com maior grau de heterogeneidade.

Em seguida, observaram-se pequenos grupos após a análise de agrupamentos das bacias, dessa forma, estas necessitaram de uma análise final. Esta última análise envolveu uma tabulação cruzada com as classes do mapa de landforms elaborado na escala de 1: 50.000 por Magri (2013) e as unidades geoambientais.

Logo, a planilha com o percentual de área das classes do mapa de landforms foi utilizada como dados de entrada para a realização da última análise de agrupamentos. Após a elaboração do dendrograma, verificou-se a junção das unidades que apresentam igualdade nas formas de relevo. A partir desta última análise foram definidas as delimitações das unidades geoambientais da área de estudo.

\subsubsection{Análise do meio físico das unidades geoambientais}

Após a análise de agrupamentos foi realizada uma análise descritiva das unidades geoambientais com base nos percentuais de área das classes de cinco documentos cartográficos, sendo eles: materiais inconsolidados (apenas a parte textural); substrato rochoso; landforms; sistemas aquíferos e declividade. Esta análise também envolveu produtos cartográficos interpretativos, dessa forma as unidades também foram caracterizadas conforme: o potencial à produção rural; a suscetibilidade à erosão; o escoamento superficial; a capacidade de infiltração; e a suscetibilidade à inundação.

Estes documentos foram elaborados na mesma escala deste trabalho e disponibilizados por diversos autores da equipe do Projeto Grande Minas que realizou o Zoneamento Ambiental dos Afluentes Mineiros do Médio Rio Grande, de acordo com o item 4.1. Esta 
análise quantitativa e descritiva auxiliou na proposição de recomendações (item 4.2.8) que visam à melhoria das unidades geoambientais.

\subsubsection{Análise das unidades geoambientais com relação às zonas de manejo da unidade de conservação}

Segundo o artigo $2^{\circ}$ da Lei Federal n ${ }^{\circ}$ 9.985/2000 (Sistema Nacional de Unidades de Conservação), define zoneamento como "divisão de áreas em setores ou zonas em uma unidade de conservação com objetivos de manejo e normas específicas, para fins de proporcionar de forma condizente e eficaz os meios e as condições para que todos os objetivos da unidade sejam realizados".

Neste trabalho também foi realizada uma análise com as unidades geoambientais quanto à sua distribuição nas zonas de manejo do Parque Nacional da Serra da Canastra (PNSC), realizadas pelo Instituto Brasileiro do Meio Ambiente e dos Recursos Naturais Renováveis (IBAMA), no ano de 2005.

Segundo o zoneamento do PNSC a área de estudo apresenta três zonas de manejo, sendo elas: Zona Intangível (ZI); Zona de Ocupação Temporária (ZOT); e Zona de Amortecimento (ZAm).

Logo após o estudo de cada uma das zonas estabelecidas no plano de manejo da unidade de conservação, foi executado o cálculo do percentual de área de cada zona considerando as nove unidades geoambientais e vice-versa. Esta etapa foi realizada para verificar o percentual de área das unidades que estão situadas em cada zona, de modo a identificar se estas unidades estão sendo utilizadas respeitando as finalidades do plano de manejo do PNSC.

Esta análise em conjunto com o uso e ocupação do solo da área de estudo, possibilitou averiguar se ocorre ou não usos conflitantes nas unidades geoambientais, para isto foi necessário considerar as zonas de manejo da área protegida.

\subsubsection{Mapeamento das áreas ambientais com restrições legais}

O mapeamento das áreas ambientais com restrições legais representa as regiões que possuem grande relevância ambiental para a preservação e conservação de um determinado 
local. Alguns autores elaboraram o Mapa de Legislação Ambiental para auxiliar o planejamento de uma determinada área quanto ao ordenamento territorial, dentre eles citam-se Rodríguez (2005), Spironello (2007), Silva (2007), entre outros.

O mapeamento destas áreas foi elaborado com base nas características da área de estudo e os critérios instituídos pela legislação brasileira (Tabela 24). As Áreas de Preservação Permanente (APPs) são consideradas o principal atributo no Mapa de Legislação Ambiental, estas áreas foram delimitadas com base nos fundamentos do Novo Código Florestal (Lei Federal n 12.651/2012) e na Resolução CONAMA nº 302/2002.

Além das APPs, também foi considerada a área da unidade de conservação (área regularizada e área em processo de regularização) e sua zona de amortecimento dentro da área de estudo. Estas regiões foram estabelecidas no zoneamento do Parque Nacional da Serra da Canastra, considerando os critérios exigidos pela Lei Federal nº 9.985/2000.

Tabela 24 - Critérios adotados para a elaboração do Mapa de Legislação Ambiental.

\begin{tabular}{|c|c|c|}
\hline \multicolumn{3}{|c|}{ Critérios estabelecidos pela Legislação Brasileira } \\
\hline $\begin{array}{c}\text { Áreas de Preservação } \\
\text { Permanente }\end{array}$ & $\begin{array}{l}\text { Faixas Marginais de } \\
\text { qualquer curso d'água }\end{array}$ & $\begin{array}{l}\text { 30m para cursos d'água de menos de } 10 \mathrm{~m} \text { de } \\
\text { largura }\end{array}$ \\
\hline $\begin{array}{l}\left.\text { (Lei Federal } n^{\circ} 12.651 / 2012\right) \\
\quad \text { Inciso I do Artigo } 4^{\circ}\end{array}$ & $\begin{array}{l}\text { natural perene e } \\
\text { intermitente }\end{array}$ & $\begin{array}{l}50 \mathrm{~m} \text { para cursos d'água que tenham de } 10 \text { a } \\
50 \mathrm{~m} \text { de largura }\end{array}$ \\
\hline $\begin{array}{l}\text { Áreas de Preservação } \\
\text { Permanente } \\
\text { (Resolução CONAMA } \\
n^{\circ} \text { 302/2002) } \\
\text { Inciso I do Artigo } 3^{\circ}\end{array}$ & \multicolumn{2}{|c|}{$\begin{array}{l}\text { Trinta metros para os reservatórios artificiais situados em áreas urbanas } \\
\text { consolidadas e cem metros para áreas rurais }\end{array}$} \\
\hline $\begin{array}{c}\text { Áreas de Preservação } \\
\text { Permanente } \\
\left.\text { (Lei Federal } n^{\circ} 12.651 / 2012\right) \\
\text { Inciso IX do Artigo } 4^{\circ}\end{array}$ & \multicolumn{2}{|c|}{$\begin{array}{l}\text { Topo de morros, montes, montanhas e serras, com altura mínima de } \\
100 \text { m e inclinação média maior que } 25^{\circ}\end{array}$} \\
\hline $\begin{array}{l}\text { Unidade de conservação } \\
\left.\text { (Lei Federal } n^{\circ} 9.985 / 2000\right) \\
\text { Inciso XVI e XVIII do } \\
\text { Artigo } 2^{\circ}\end{array}$ & \multicolumn{2}{|c|}{$\begin{array}{l}\text { Zona Intangível (área regularizada) } \\
\text { Zona de Ocupação Temporária (área não regularizada) } \\
\text { Zona de Amortecimento do Parque Nacional da Serra da Canastra }\end{array}$} \\
\hline
\end{tabular}




\subsubsection{1 Áreas de preservação permanente dos cursos d'água}

Para o mapeamento deste tipo de APPs, foi considerada a hierarquia dos canais de drenagem, sendo que para os cursos d'água de até $4^{\mathrm{a}}$ ordem foram considerados 30 metros de distância da linha de drenagem para ambos os lados, já para os canais de $5^{\mathrm{a}}$ e $6^{\mathrm{a}}$ ordem foram adotados 50 metros para ambas as margens. Vale lembrar que a rede hidrográfica utilizada foi disponibilizada pelo Projeto Grande Minas (conforme citado no item 4.1), visto que esta foi vetorizada considerando as oito cartas topográficas que contemplam a área de estudo.

A APP ao entorno do lago de Peixoto (um dos reservatórios artificiais do Rio Grande) que se encontra entre as barragens da usina de Furnas e Mascarenhas de Moraes, foi delimitada segundo a Resolução CONAMA no 302/2002, que de acordo com inciso I do Artigo $3^{\circ}$ estabelece que a faixa de APP adotada para reservatórios artificiais situados na área rural deve ser de 100 metros.

As APPs das nascentes foram desconsideradas neste mapa devido à escala de trabalho (1: 50.000), visto que nesta escala não se consegue identificar todos os canais de $1^{\mathrm{a}}$ ordem para a extração dos pontos das nascentes.

Estes procedimentos foram realizados no software Arc GIS 10.0 ${ }^{\circledR}$, através dos comandos Geoprocessing - Buffer.

\subsubsection{2 Áreas de Preservação Permanente dos topos de morros}

A delimitação das APPs dos topos de morro dependeu de análises espaciais realizadas no software Arc GIS $10.0^{\circledR}$ em conjunto com um Modelo Digital de Elevação Hidrologicamente Consistente (MDEHC).

A delimitação destas áreas envolveu a obtenção dos pontos de topo e de base dos morros por meio do MDEHC e da rede hidrográfica, bem como a amplitude da altitude e o terço superior de cada morro. Estes procedimentos foram baseados nos métodos de Santos (2013). A Tabela 25 apresenta uma síntese das etapas desenvolvidas para a elaboração deste tipo de APP. 
Tabela 25 - Etapas para a obtenção das APPs dos topos de morros, conforme Santos (2013).

\begin{tabular}{|c|c|c|}
\hline Etapas & $\begin{array}{l}\text { Dados de } \\
\text { entrada }\end{array}$ & Procedimentos \\
\hline $\begin{array}{l}\text { Extração dos } \\
\text { topos de morros }\end{array}$ & MDEHC & $\begin{array}{l}\text { - Inversão do MDEHC } \\
\text { - Direção de Fluxo do MDEHC invertido } \\
\text { - Obtenção dos pontos do topo de morro e montanhas } \\
\text { - Obtenção da altitude real } \\
\text { - Obtenção da área de abrangência de cada morro } \\
\text { (Arc Toolbox - Spatial Analyst Tools - Hydrology - Watershed) }\end{array}$ \\
\hline $\begin{array}{c}\text { Extração da } \\
\text { base dos morros }\end{array}$ & $\begin{array}{l}\text { Rede de } \\
\text { Drenagem }\end{array}$ & $\begin{array}{l}\text { - Obtenção dos pontos de confluência } \\
\text { (Arc Toolbox - Data Management Tools - Feature - Features } \\
\text { Vertices to Points) } \\
\text { - Obtenção da altitude de cada ponto de confluência } \\
\text { (Arc Toolbox - Spatial Analyst Tools - Extraction - Extraction } \\
\text { Value to Points) } \\
\text { - Transformação dos pontos de confluência de formato vetorial } \\
\text { para formato raster } \\
\text { - Obtenção da área de abrangência do ponto da base do morro }\end{array}$ \\
\hline $\begin{array}{c}\text { Delimitação do } \\
\text { terço superior } \\
\text { dos topos de } \\
\text { morro }\end{array}$ & $\begin{array}{l}\text { Altitude do topo } \\
\text { e da base dos } \\
\text { morros }\end{array}$ & $\begin{array}{l}\text { - Cálculo da razão da amplitude de cada célula do MDEHC e da } \\
\text { base do morro, com a amplitude da base ao topo do morro. }\end{array}$ \\
\hline $\begin{array}{l}\text { Extração da } \\
\text { APP dos topos } \\
\text { de morros }\end{array}$ & MDEHC & $\begin{array}{l}\text { - Obtenção da declividade } \\
\text { - Obtenção da área de abrangência de cada morro } \\
\text { - Obtenção da declividade média } \\
\text { - Reclassificação das áreas dos morros com declividade média } \\
\text { superior a } 25^{\circ} \\
\text { - Transformar as áreas do terço superior dos morros de formato } \\
\text { matricial para o formato vetorial }\end{array}$ \\
\hline
\end{tabular}

\subsubsection{Análise das áreas ambientais com restrição legal nas unidades geoambientais}

A análise realizada das áreas ambientais que apresentam restrições legais envolveu a contabilização do percentual de área de cada tipo de APP apresentado neste trabalho, considerando a delimitação das unidades geoambientais. 
Em seguida os dados quantitativos foram tabulados em planilha do formato Excel. Após este procedimento, foi utilizado o software Arc GIS $10.0^{\circledR}$ para a intersecção das delimitações das APPs (mapeadas conforme a legislação) e as áreas de vegetação natural extraídas do mapa de uso e ocupação do solo atualizado de Dias (2013). As ferramentas utilizadas para tal procedimento foram: Geoprocessing - Intersect.

Logo, foi tabulado o percentual de área de vegetação natural, o qual se refere às áreas de mata, campo e capoeira dentro das áreas de preservação permanentes mapeadas neste trabalho considerando os aspectos legais. Esta etapa foi realizada para identificar se as APPs dentro das unidades geoambientais do município de Delfinópolis estão condizentes com o que determina a legislação vigente.

\subsubsection{Análise das Unidades Geoambientais em relação ao uso e ocupação do solo}

\subsubsection{Edição do uso e ocupação do solo}

O mapa de uso e ocupação do solo foi atualizado de Dias (2013), tendo sido elaborado para a Bacia Hidrográfica do Médio Rio Grande (GD7) utilizando seis imagens do satélite ALOS, multiespectral (12,5 x 12,5 m), com resolução espacial de 2,5 x 2,5 m, datadas de 2009.

Para a atualização deste mapa temático foi utilizada a forma de edição básica disponibilizada pelas ferramentas do comando Editor presentes no Arc GIS 10.0 ${ }^{\circledR}$. No mesmo

software foram inseridas as 40 imagens de satélite adquiridas através do Google Earth Pro ${ }^{\circledR}$ (citadas no item 4.2.1.2). Através destas imagens, os polígonos que constituem o mapa de uso e ocupação elaborado por Dias (2013) foram editados para suas atuais classes, o que consequentemente resultou na alteração de suas informações (classe e área) na tabela de atributos do shape.

O mapa de uso e ocupação do solo do município foi atualizado para realizar a identificação e análise das unidades geoambientais quanto aos seus usos conflitantes, bem como no cálculo do Índice de Transformação Antrópica (ITA). 


\subsubsection{Obtenção do Índice de Transformação Antrópica (ITA)}

O ITA foi desenvolvido por Lémechev (1982) e aplicado por Mateo (1984), para a quantificação da pressão antrópica sobre algum componente do meio ambiente, como exemplo, as áreas de proteção ambiental, as bacias hidrográficas ou parques nacionais (ROCHA; CRUZ, 2009).

Neste trabalho o ITA foi utilizado para a quantificação da pressão antrópica das nove unidades geoambientais. Inicialmente foram unidas as subclasses dos tipos de uso e ocupação do solo respeitando o potencial de cada classe em provocar degradação, conforme a Tabela 26. Posteriormente foi calculado o percentual de área de cada uma das classes para cada unidade geoambiental.

Após este cálculo, foram definidos os respectivos pesos para cada um dos usos respeitando a importância de cada classe referente ao processo de degradação (Tabela 27).

Tabela 26 - Subclasses e classes do mapa de uso e ocupação do solo.

\begin{tabular}{|c|c|c|c|}
\hline Subclasses & \multicolumn{2}{|l|}{ Classes } & \multirow{4}{*}{$\begin{array}{c}\text { De maior } \\
\text { a menor } \\
\text { pressão } \\
\text { antrópica }\end{array}$} \\
\hline Área Urbana & \multirow{2}{*}{ Área Construída } & \multirow{2}{*}{1} & \\
\hline Chacreamento & & & \\
\hline Mineração & Mineração & 2 & \\
\hline Solo Exposto & \multirow{2}{*}{ Solo Exposto } & \multirow{2}{*}{3} & \\
\hline Erosão & & & \\
\hline Estada Rural & \multirow{3}{*}{ Estrada } & \multirow{3}{*}{4} & \\
\hline Estrada Municipal & & & \\
\hline Estrada Pavimentada & & & \\
\hline Indústria & \multirow{3}{*}{ Atividade Pontual } & \multirow{3}{*}{5} & \\
\hline Barramentos & & & \\
\hline Disposição de Resíduos Sólidos & & & \\
\hline Pastagem & Pastagem & 6 & \\
\hline Cultura Anual & \multirow{3}{*}{ Área Agrícola } & \multirow{3}{*}{7} & \\
\hline Cultura Permanente & & & \\
\hline Silvicultura & & & \\
\hline Mata & \multirow{3}{*}{ Área de Vegetação Natural } & \multirow{3}{*}{8} & \\
\hline Campo & & & S \\
\hline Capoeira & & & \\
\hline
\end{tabular}


Tabela 27 - Pesos para os respectivos tipos de uso e ocupação do solo no município.

\begin{tabular}{c|c}
\hline Tipos de Uso e Ocupação do Solo & Pesos \\
\hline Área Construída & 10 \\
\hline Mineração & 9 \\
\hline Solo Exposto & 9 \\
\hline Estradas & 8 \\
\hline Atividades Pontuais & 8 \\
\hline Pastagem & 7 \\
\hline Área Agrícola & 7 \\
\hline Área de Vegetação Natural & 1 \\
\hline
\end{tabular}

Em seguida foi realizado o cálculo do índice para cada uma das unidades geoambientais, utilizando a Equação 10 definida por Mateo (1984) apud Rocha e Cruz (2009):

$$
I T A=\sum(\% \text { Uso } \times \text { Peso }) / 100
$$

Onde,

Uso: percentual de área das classes do uso e ocupação do solo;

Peso: escala atribuída com variação de 1 a 10, que dependerá dos tipos de uso e ocupação do solo.

Depois do cálculo do índice, as nove unidades geoambientais foram classificadas quanto ao seu grau de degradação, conforme o método estabelecido por Cruz et al. (1998). A Tabela 28 apresenta as classes e os seus respectivos intervalos.

Tabela 28 - Classes do Índice de Transformação Antrópica definidas por Cruz et al. (1998).

\begin{tabular}{|c|c|}
\hline Classes & Intervalos de valores \\
\hline Pouco Degradada & $0-2,5$ \\
\hline Regular & $2,5-5,0$ \\
\hline Degradada & $5,0-7,5$ \\
\hline Muito Degradada & $7,5-10$ \\
\hline
\end{tabular}




\subsubsection{Análise do uso e ocupação do solo nas unidades geoambientais}

Após a atualização do mapa de uso e ocupação do solo e o cálculo do percentual de área de cada classe, as unidades geoambientais foram descritas quanto aos seus usos predominantes.

Nesta análise também foi considerada a localização das unidades para identificar se elas enquadram na finalidade imposta pelas zonas de manejo da unidade de conservação definidas no zoneamento do PNSC. Esta análise permitiu identificar se existe a ocorrência de usos em regiões inadequadas para ocupação sob do ponto de vista legal.

Nesta etapa também foi elaborado o mapa de Carga Antrópica para as unidades geoambientais, visto que este produto mostrou a espacialização das unidades e os seus níveis de degradação, levando em consideração os valores calculados do ITA.

\subsubsection{Estabelecimento de recomendações para as unidades geoambientais}

Após os procedimentos estatísticos e computacionais descritos anteriormente, as unidades geoambientais foram caracterizadas com base nas cinco análises efetuadas. A Tabela 29 apresenta a relação das análises realizadas neste trabalho e seus respectivos produtos utilizados.

A partir destas análises foi realizada uma síntese da situação que se encontra cada unidade, assim, foram considerados os pontos que merecem maior atenção para evitar o surgimento ou agravamento dos problemas encontrados, como exemplo, processos erosivos. Alem destes, foram considerados também os pontos que devem ser devidamente gerenciados para manter e melhorar as condições ambientais da área, como exemplo, as unidades que apresentam alto percentual de áreas preservadas.

Desse modo, esta etapa do trabalho consistiu em propor algumas recomendações considerando separadamente as condições que se encontram as nove unidades geoambientais com base nas cinco análises realizadas, de forma que assegure o uso racional dos recursos naturais possibilitando o desenvolvimento sustentável do município. 
Tabela 29 - Tipos de análises realizadas para as unidades geoambientais e os produtos utilizados para cada uma delas.

\begin{tabular}{|c|c|}
\hline Análises das Unidades Geoambientais & Produtos Utilizados \\
\hline Características físicas & $\begin{array}{l}\text { - \% de área das classes dos materiais inconsolidados } \\
\text { - \% de área das classes dos substratos rochosos } \\
\text { - \% de área das classes dos sistemas aquíferos } \\
\text { - \% de área das classes de landforms } \\
\text { - \% de área das classes de declividades }\end{array}$ \\
\hline Potencialidades e suscetibilidades & $\begin{array}{l}\text { - \% de área das classes de potencial à produção rural } \\
\text {-\% de área das classes de potencial ao escoamento } \\
\text { superficial } \\
\text { - \% de área das classes de capacidade de infiltração } \\
\text { - \% de área das classes de suscetibilidade à erosão } \\
\text { - \% de área das classes de suscetibilidade à inundação }\end{array}$ \\
\hline Zonas de manejo do PNSC & $\begin{array}{l}\text { - \% das áreas das unidades geoambientais dentro de } \\
\text { cada zona de manejo (ZI, ZOT e ZAm) } \\
\text { - \% das áreas das zonas de manejo (ZI, ZOT e ZAm) } \\
\text { para as nove unidades geoambientais }\end{array}$ \\
\hline Áreas ambientais com restrição legal & $\begin{array}{l}\text { - \% de APP dos cursos d'água de } 1^{\mathrm{a}}, 2^{\mathrm{a}}, 3^{\mathrm{a}} \text { e } 4^{\mathrm{a}} \text { ordem } \\
\text { - \% de APP dos cursos d'água de } 5^{\mathrm{a}} \text { e } 6^{\mathrm{a}} \text { ordem } \\
\text { - \% de APP do Reservatório de Peixoto } \\
\text { - \% de APP de topos de morros } \\
\text { - \% de vegetação natural (mata, campo e capoeira) que } \\
\text { compõe os quatro tipos de APPs consideradas neste } \\
\text { trabalho }\end{array}$ \\
\hline Uso e ocupação do solo & $\begin{array}{l}\text { - \% de área de cada classe do uso e ocupação do solo } \\
\text { - valores do Índice de Transformação Antrópica (ITA) }\end{array}$ \\
\hline
\end{tabular}




\section{Resultados e discuSSÃo}

\subsection{Análise de agrupamentos para o estabelecimento das unidades geoambientais}

A análise de agrupamentos realizada no software Statistica $13^{\circledR}$ teve como objetivo agrupar as bacias hidrográficas que apresentaram maior nível de similaridade quanto às características do meio físico. Como mostrado no item 4.2.3.3, às análises foram realizadas individualmente respeitando os níveis de hierarquia das bacias $\left(1^{\mathrm{a}}, 2^{\mathrm{a}}, 3^{\mathrm{a}}\right.$ e $4^{\mathrm{a}}$ ordem).

A seguir estão sendo apresentados os dendrogramas elaborados para cada ordem das bacias hidrográficas estudadas no município.

\subsubsection{Análise de agrupamentos das bacias hidrográficas de $1^{\mathrm{a}}$ ordem}

Para as bacias de $1^{\mathrm{a}}$ ordem foi realizada a análise de agrupamentos considerando os valores percentuais de área dos atributos do meio físico (materiais inconsolidados; substrato rochoso; e declividade). As tabelas dos percentuais de área de cada classe dos três atributos utilizadas para a primeira e última análise de agrupamentos se encontram respectivamente, no Apêndice A e B.

As Figuras 23 e 24 apresentam respectivamente e o mapa de materiais inconsolidados (classes correspondentes à fração granulométrica) e o mapa de substrato rochoso, visto que estes foram devidamente ajustados para a área de estudo, pois os originais abrangiam toda a Bacia Hidrográfica do Médio Rio Grande.

De acordo com o mapa de materiais inconsolidados elaborado por Magri (2013), a fração granulométrica de maior ocorrência no município é a areia, presente em quase um terço da área de estudo $\left(481,13 \mathrm{~km}^{2}\right)$. Este material encontra-se na porção norte de Delfinópolis, assim como as seguintes classes: o silte; silte e rocha; e áreas que apresentam maior percentual das partículas de silte e argila.

Na porção sul do município a classe textural do material inconsolidado predominante é a distribuída de areia, pois nesta região encontram-se rochas de xistos com intercalações de quartzito que podem ter dado origem a este tipo de solo, ou também, pode ser um solo 
retrabalhado, visto que o solo presente na região norte onde as altitudes são mais elevadas pode ter sido transportado pela ação da gravidade.

Figura 23 - Mapa de materiais inconsolidados da área de estudo.

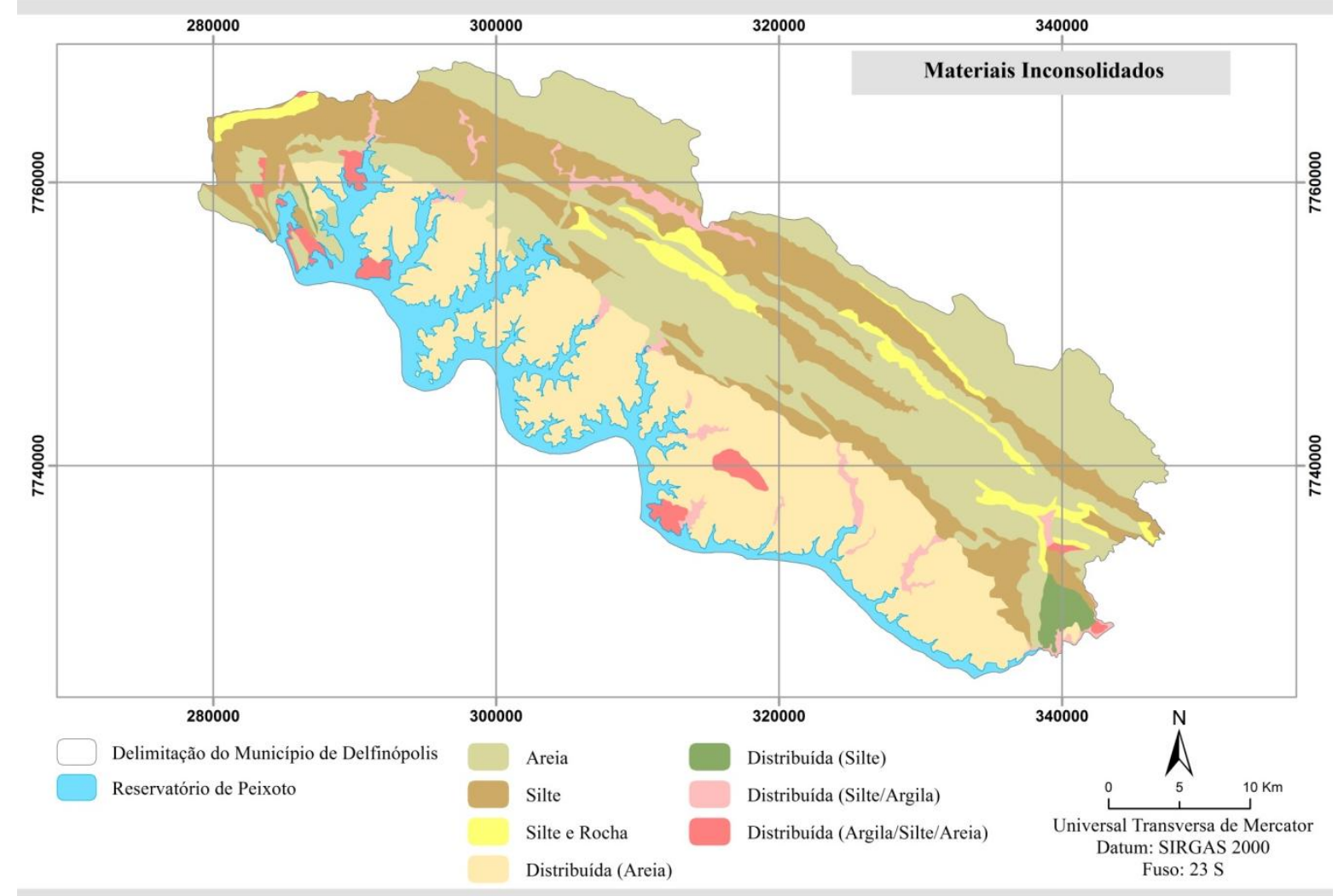

Fonte: Adaptado de Magri (2013).

Conforme o mapa de substrato rochoso adaptado de Collares e Gomes (2013), o município é composto na sua maior parte por rochas metamórficas do Grupo Araxá e Canastra, sendo o quartzito o substrato rochoso mais predominante, correspondendo a 433,87 $\mathrm{km}^{2}(34,82 \%$ da área total). Este substrato se encontra distribuído na região norte da área de estudo, intercalado com rochas de xisto e milonito, estes dois últimos subtratos constituem uma área de $238,19 \mathrm{~km}^{2}(19,11 \%$ da área total).

A porção sul do município é composta por duas litologias dominantes, sendo a primeira os xistos com intercalações de quartzito e a segunda os gnaisses, compreendendo respectivamente uma área de $310,56 \mathrm{~km}^{2}(24,92 \%)$ e $247,63 \mathrm{~km}^{2}(19,87 \%)$. Outra classe de substrato rochoso presente em Delfinópolis são as coberturas quaternárias aluvionares que totalizam em $15,85 \mathrm{~km}^{2}(1,27 \%$ da área total). 
Figura 24 - Mapa de substrato rochoso da área de estudo.

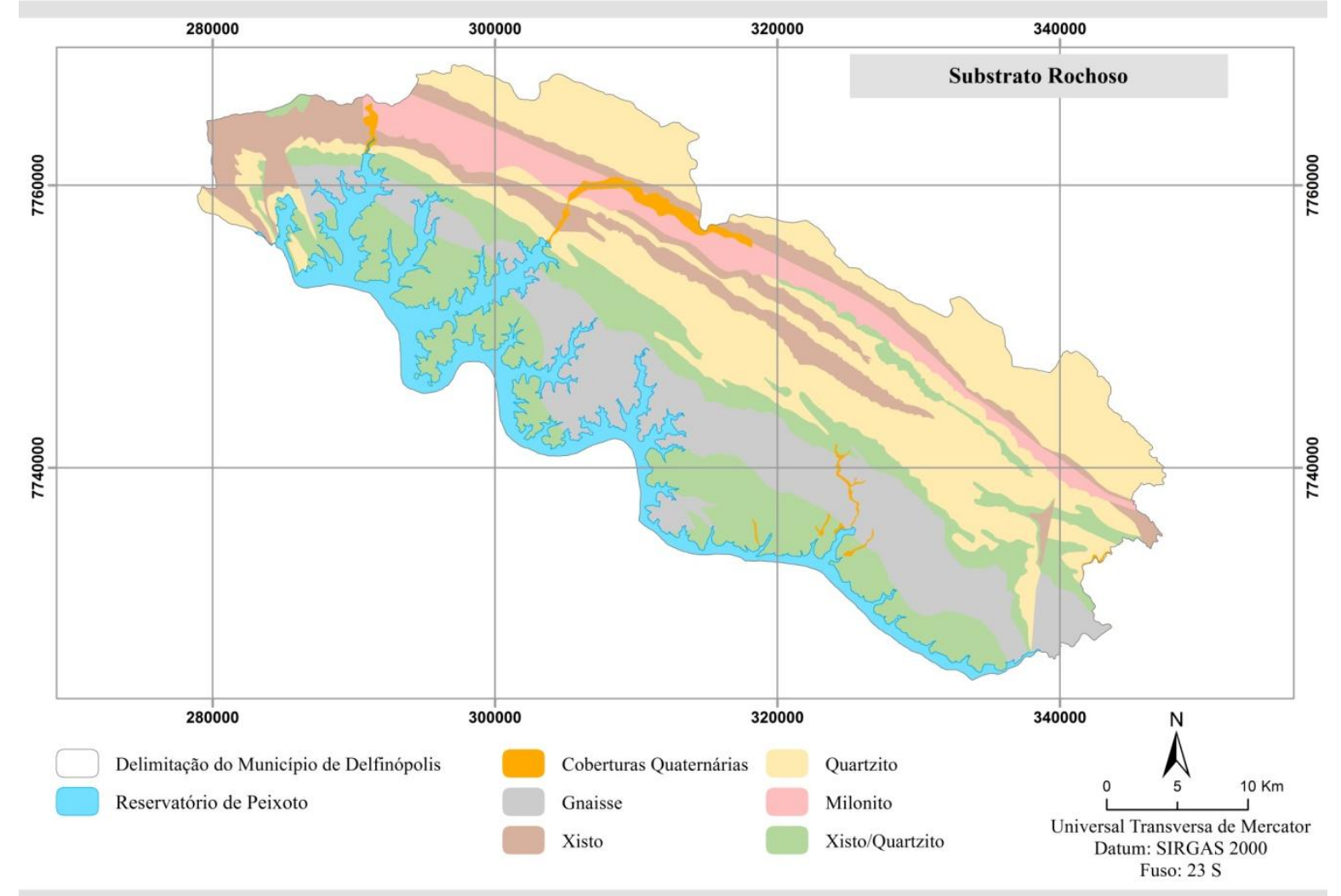

Fonte: Adaptado de Collares e Gomes (2013).

A Figura 25 mostra a Carta de Declividades elaborada para a área de estudo, com base no método descrito no item 4.2.2. O município apresenta $48,85 \%$ de suas áreas situadas em regiões de declividades baixas $(<10 \%)$, este contingente encontra-se distribuído principalmente às margens do Rio Grande, na porção sul de Delfinópolis. As declividades mais elevadas $(>30 \%)$ se encontram na extremidade norte do município, interpostas em regiões de relevo mais planos. As áreas que apresentam inclinação mais íngreme correspondem a $18,26 \%$ do território estudado, nestas localidades encontra-se o Chapadão da Babilônia, a Serra do Cemitério e a Serra da Guarita.

A Figura 26 mostra o dendrograma que representa o agrupamento das bacias hidrográficas de $1^{\mathrm{a}}$ ordem quanto aos atributos do meio físico considerados.

A união das bacias hidrográficas de $1^{a}$ ordem foi baseada na linha de fusão de $20 \%$, desse modo, 85 bacias hidrográficas existentes antes da análise estatística foram agrupadas resultando em 63 , ou seja, 25,88\% das bacias foram unidas em grupos que apresentaram similaridade entre si. 

Figura 25 - Carta de declividades da área de estudo.

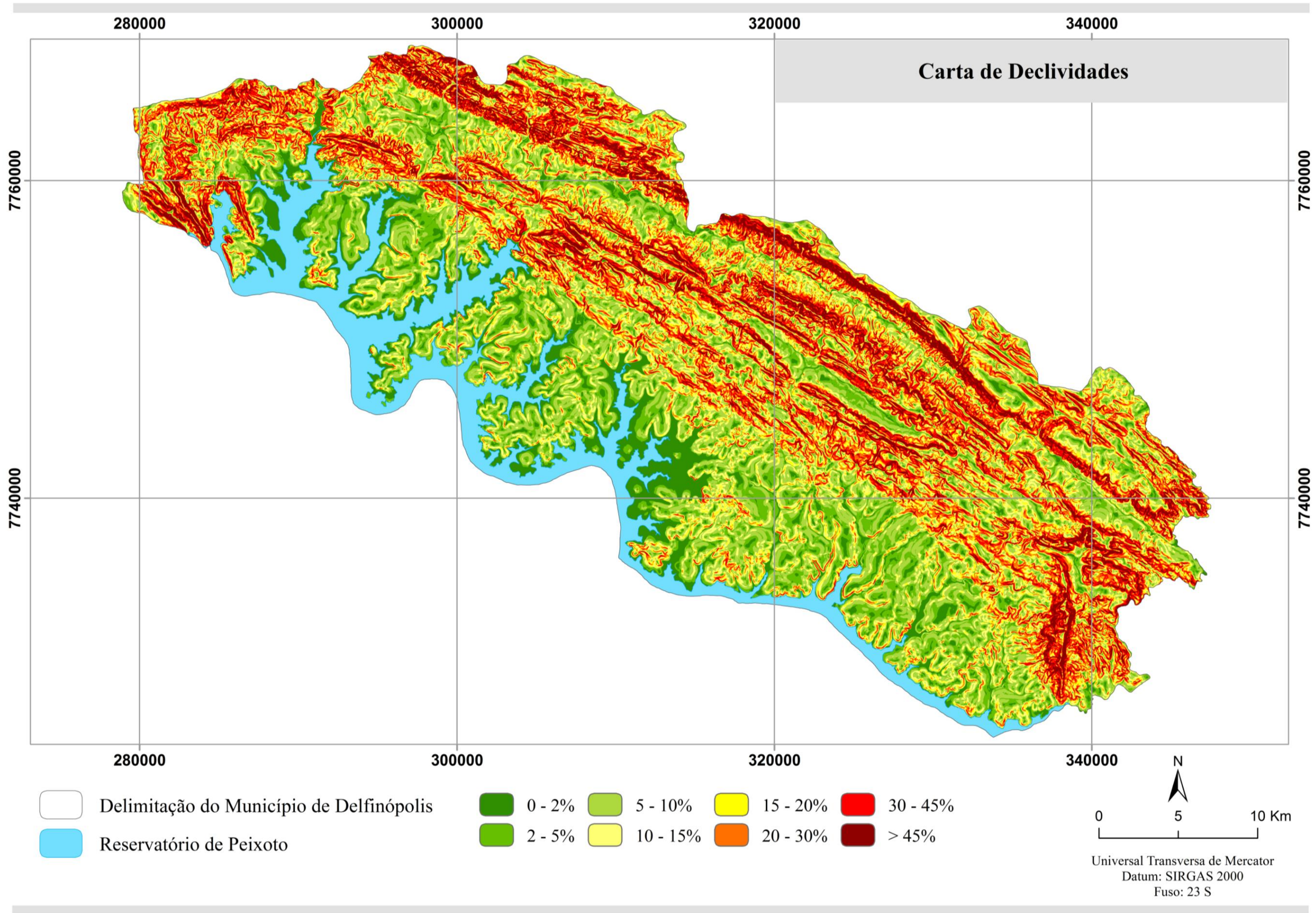



Figura 26 - Dendrograma das bacias hidrográficas de $1^{\mathrm{a}}$ ordem quanto aos atributos do meio físico.

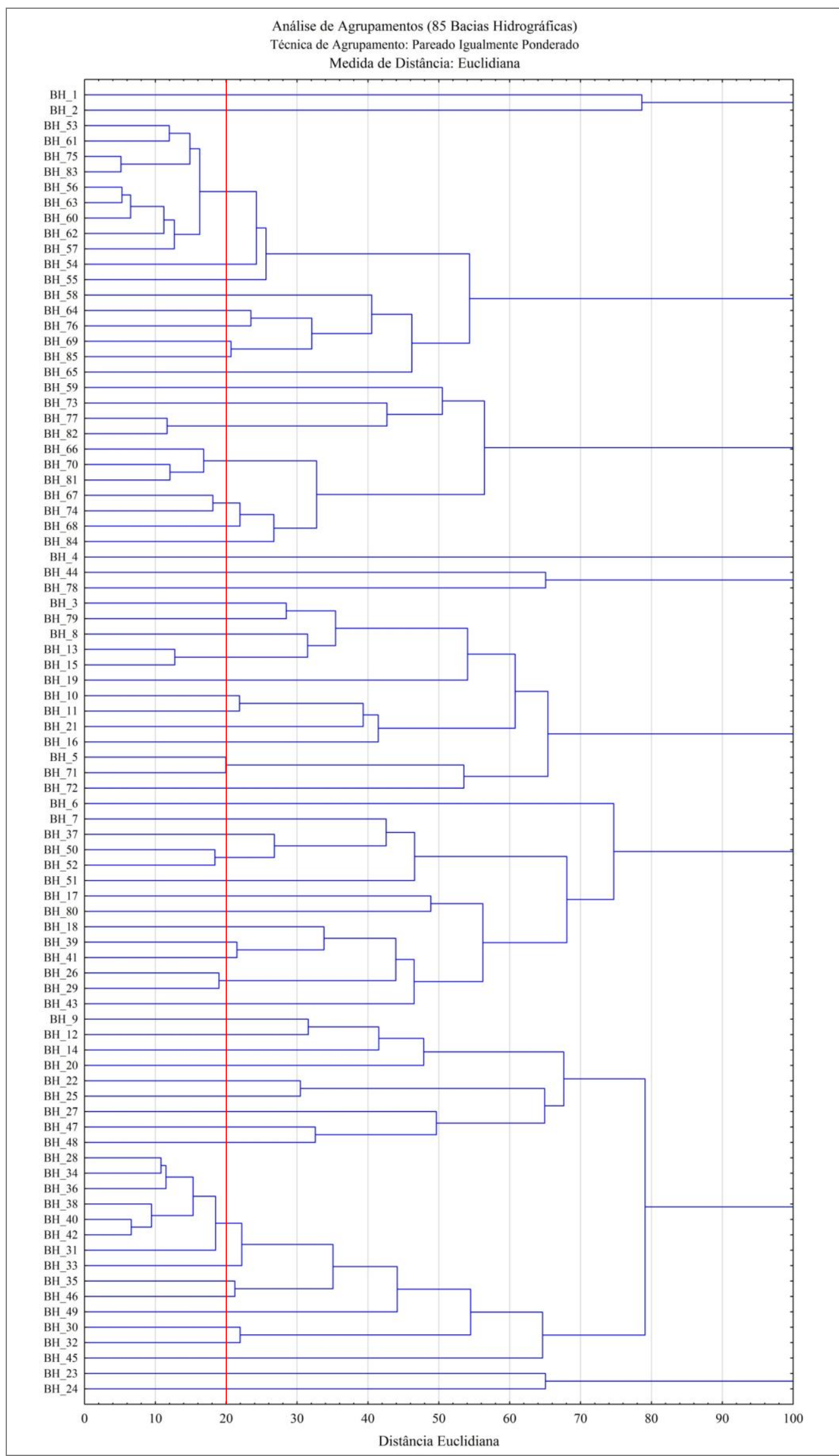

$\mathrm{N}^{\mathrm{o}}$ de $\mathrm{BH}\left(1^{\mathrm{a}}\right.$ ordem $)$ antes da AA: $85 \quad \mathrm{~N}^{\mathrm{o}}$ de $\mathrm{BH}\left(1^{\mathrm{a}}\right.$ ordem $)$ depois da AA: 63 


\subsubsection{Análise de agrupamentos das bacias hidrográficas de $2^{\mathrm{a}}, 3^{\mathrm{a}}$ e $4^{\mathrm{a}}$ ordem}

Assim como nas bacias hidrográficas de $1^{\mathrm{a}}$ ordem, esta análise também foi realizada utilizando o software Statistica $13^{\circledR}$. Conforme o item 4.2.3.2, esta análise dependeu em primeiro momento do cálculo de nove índices morfométricos. Vale ressaltar, que a técnica de agrupamento e a medida de distância foram às mesmas para todas as bacias hidrográficas.

As tabelas dos valores dos índices morfométricos das bacias de $2^{\mathrm{a}}, 3^{\mathrm{a}}$ e $4^{\mathrm{a}}$ ordem estão no Apêndice C, E e G. As tabelas dos percentuais de área dos atributos do meio físico se encontram no Apêndice D, F e H.

A Figura 27 apresenta o dendrograma que mostra a análise de agrupamentos das 100 bacias hidrográficas de $2^{\mathrm{a}}$ ordem, considerando os valores morfométricos. Após a análise, esta centena de unidades resultou em apenas 34 bacias, ou seja, $66 \%$ das bacias hidrográficas de $2^{\mathrm{a}}$ ordem foram agrupadas.

A Figura 28 mostra o dendrograma após a análise de agrupamentos quanto aos atributos do meio físico. Pode-se observar que ocorreu ainda uma junção no número de bacias de $2^{\mathrm{a}}$ ordem, visto que após a segunda análise de agrupamentos o número de bacias resultou em 30 .

Dessa forma, considera-se que, por não ter havido alteração significativa no número de agrupamentos, o uso dos índices morfométricos permitiu o agrupamento de bacias com características semelhantes com relação aos atributos do meio físico considerados.

As bacias hidrográficas de $3^{\mathrm{a}}$ ordem antes da primeira análise de agrupamentos totalizavam em 37. Logo após a análise, houve uma junção de 54,1\% das bacias resultando em 17 (Figura 29). A Figura 30 apresenta o dendrograma da segunda análise de agrupamentos realizada com base nos atributos do meio físico, que manteve o número de bacias constante. Mais uma vez demonstrando a validade do uso dos índices morfométricos no agrupamento para geração de unidades homogêneas.

Conforme apresenta a Figura 31 as bacias hidrográficas de $4^{\mathrm{a}}$ ordem totalizam 26. Posteriormente a primeira análise de agrupamentos, com base na morfometria, $57,7 \%$ das bacias foram unidas. A Figura 32 apresenta o dendrograma após a segunda análise realizada (com relação aos atributos do meio físico), também neste caso não ocorreu alteração significativa na quantidade de bacias. 
Figura 27 - Dendrograma da análise de agrupamentos das bacias hidrográficas de $2^{\mathrm{a}}$ ordem, com relação aos índices morfométricos.

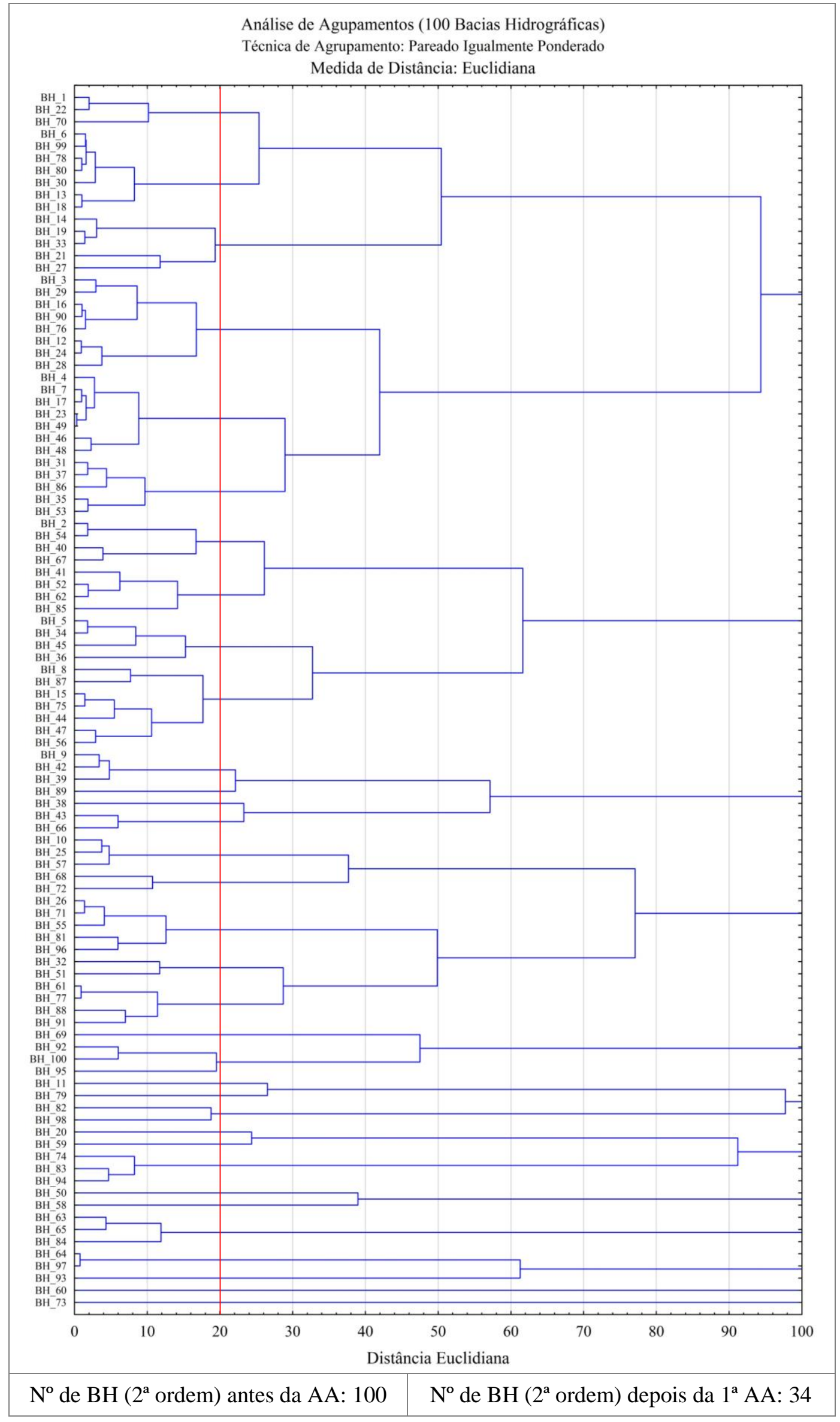


Figura 28 - Dendrograma da análise de agrupamentos das bacias hidrográficas de $2^{\mathrm{a}}$ ordem, com relação aos atributos do meio físico.

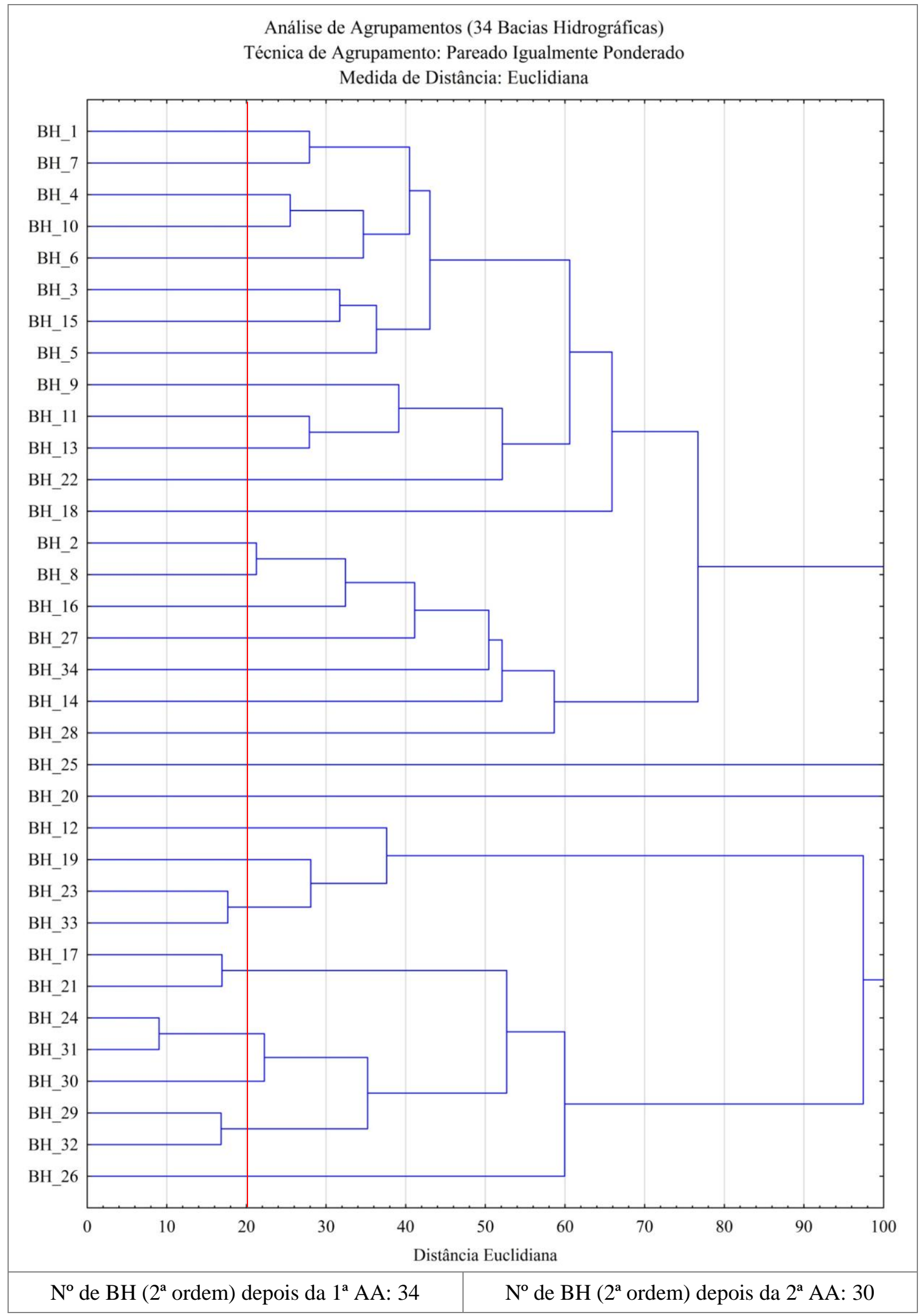


Figura 29 - Dendrograma da análise de agrupamentos das bacias hidrográficas de $3^{\text {a }}$ ordem, com relação aos índices morfométricos.

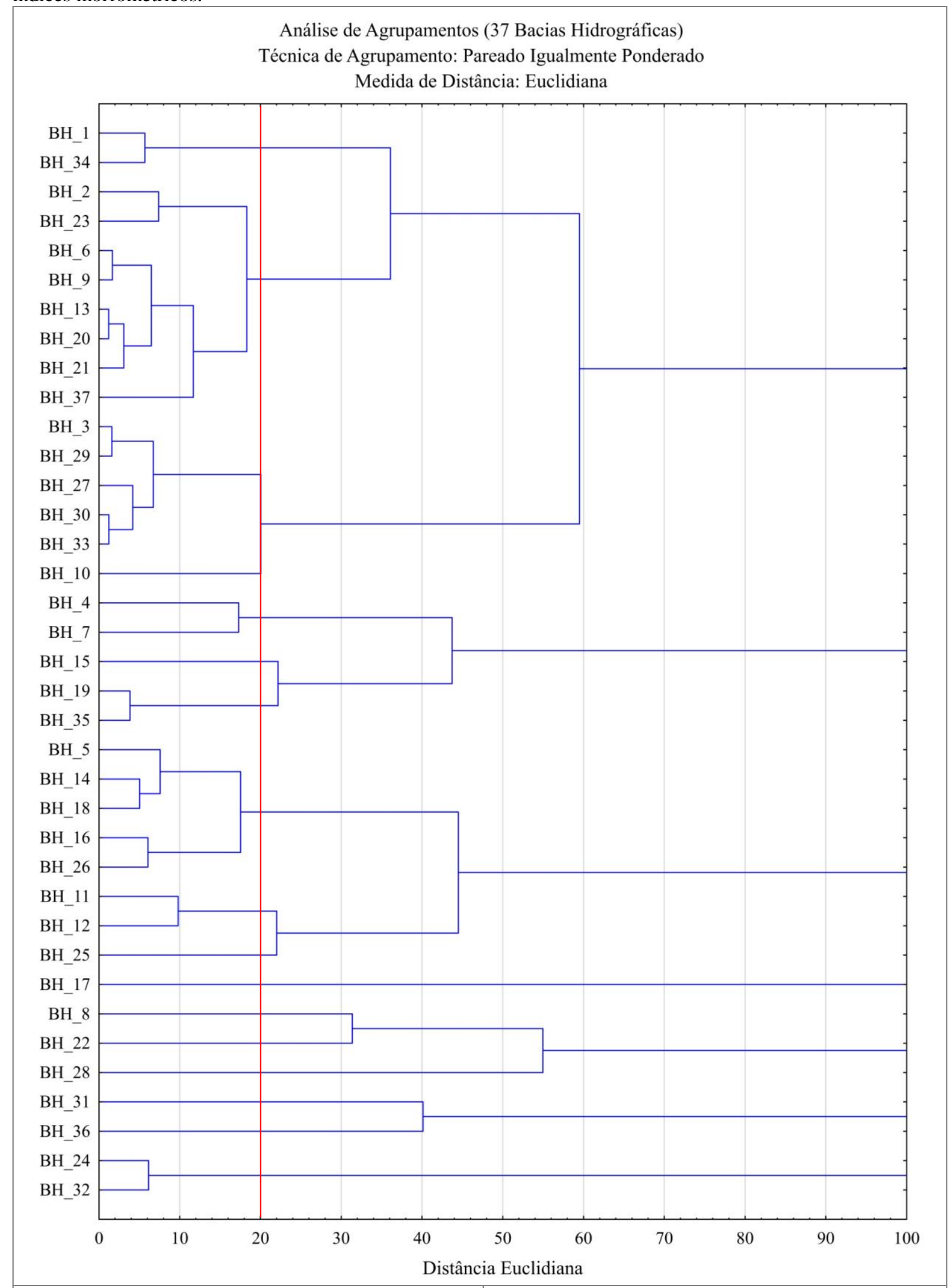


Figura 30 - Dendrograma da análise de agrupamentos das bacias hidrográficas de $3^{\mathrm{a}}$ ordem, com relação aos atributos do meio físico.

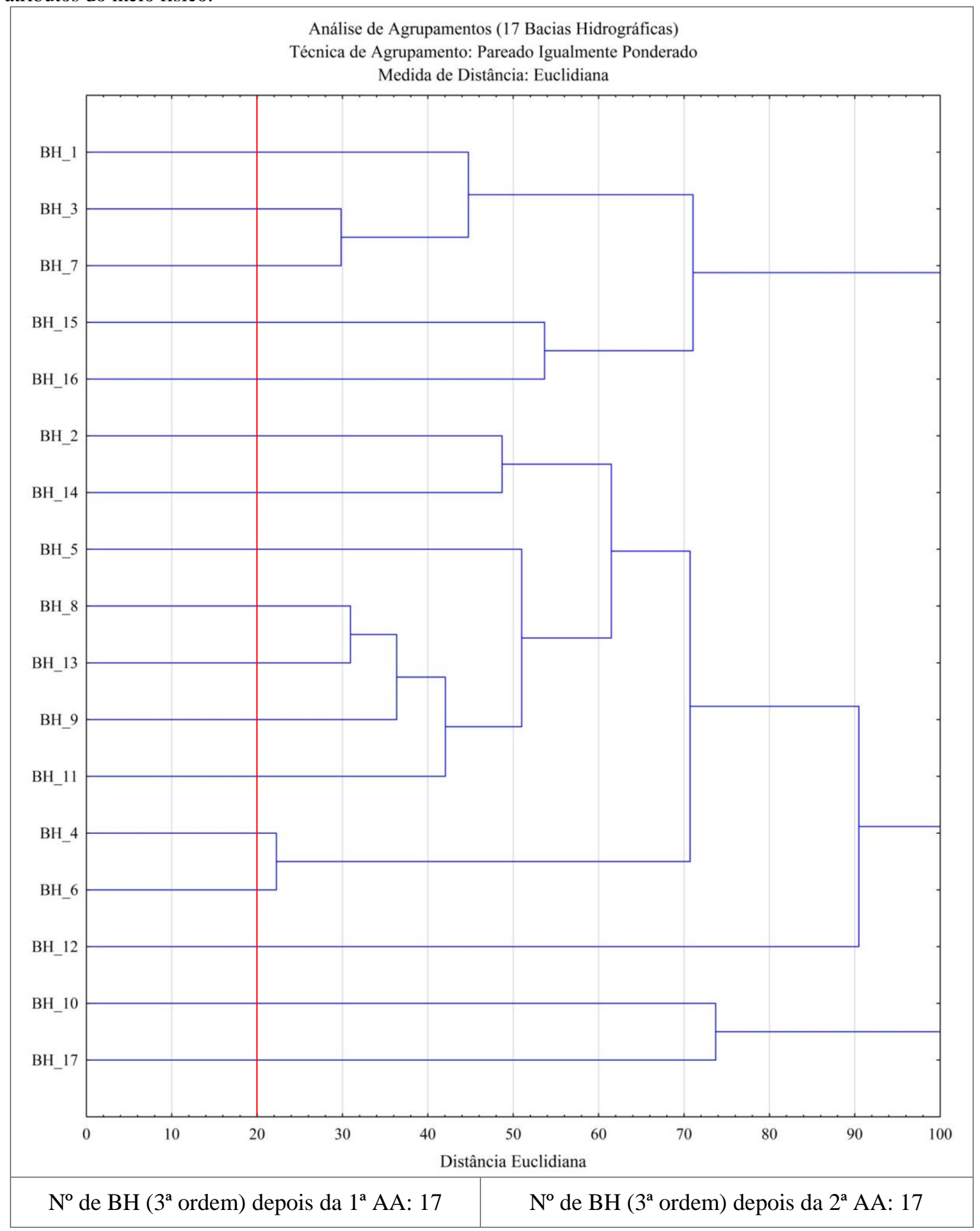


Figura 31 - Dendrograma da análise de agrupamentos das bacias hidrográficas de $4^{\mathrm{a}}$ ordem, com relação aos índices morfométricos.

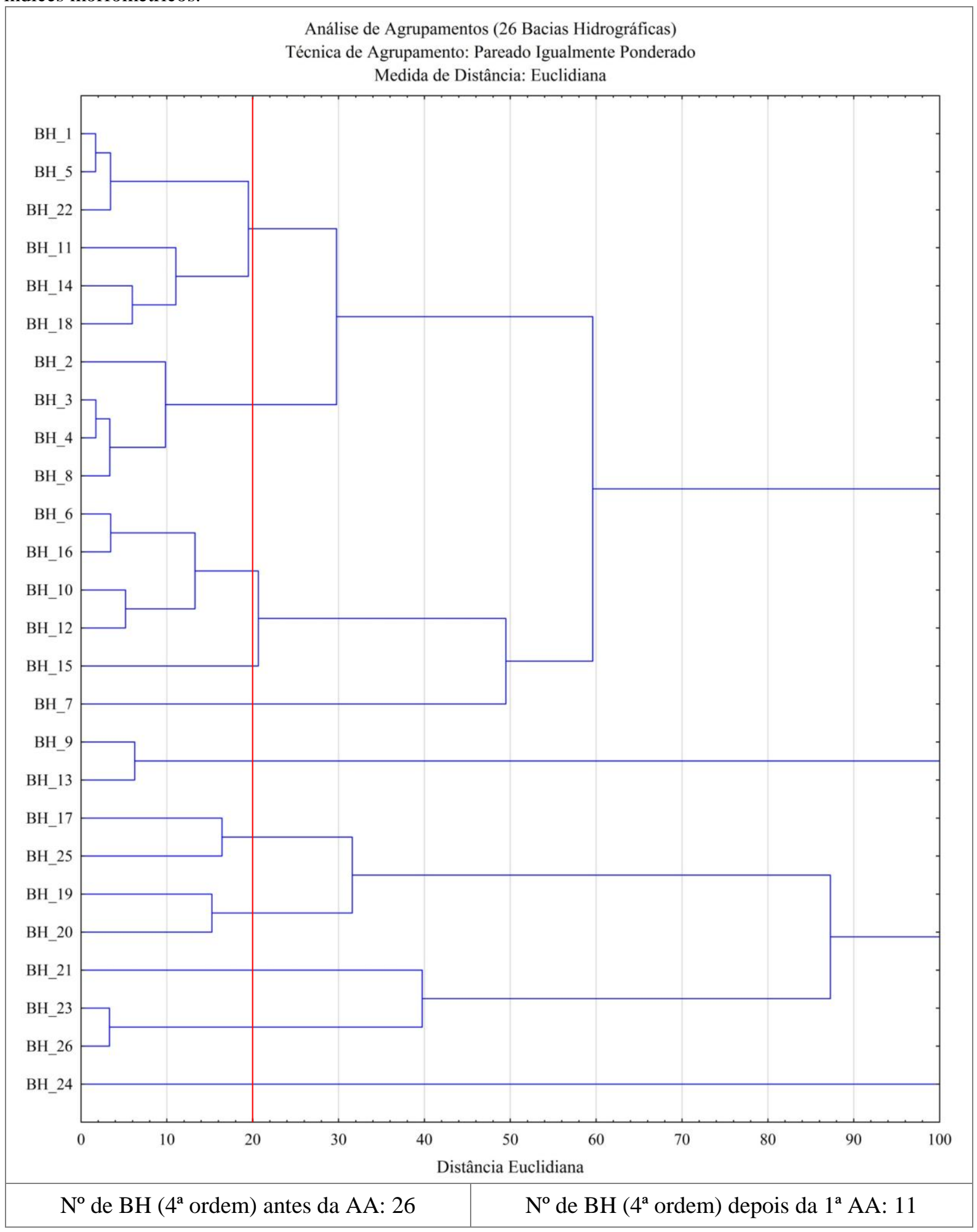


Figura 32 - Dendrograma da análise de agrupamentos das bacias hidrográficas de $4^{\mathrm{a}}$ ordem, com relação aos atributos do meio físico.

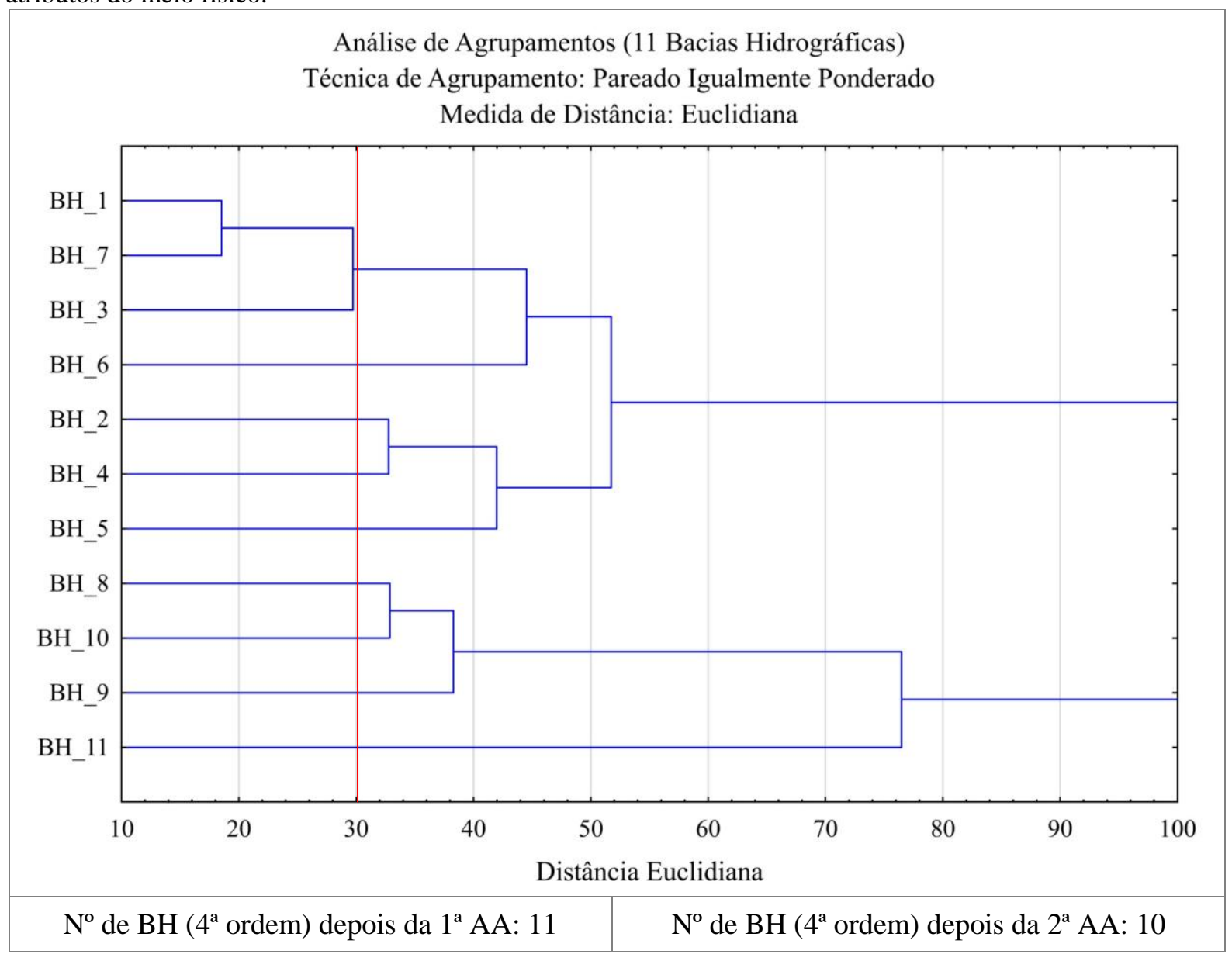

\subsubsection{Delimitação das Unidades Geoambientais}

A Tabela 30 apresenta a quantidade de bacias hidrográficas de $1^{\mathrm{a}}, 2^{\mathrm{a}}, 3^{\mathrm{a}}$ e $4^{\mathrm{a}}$ ordem antes e depois das análises de agrupamentos. A Figura 33 apresenta o mapa das bacias hidrográficas antes das análises de agrupamentos.

Tabela 30 - Número de bacias antes e depois das análises de agrupamentos.

\begin{tabular}{|c|c|c|c|c|}
\hline $\begin{array}{c}\text { Bacias } \\
\text { Hidrográficas }\end{array}$ & $\begin{array}{l}\text { Total de unidades } \\
\text { antes das análises } \\
\text { de agrupamentos }\end{array}$ & $\begin{array}{c}1^{\text {a }} \text { Análise de } \\
\text { agrupamentos } \\
\text { (Índices } \\
\text { Morfométricos) }\end{array}$ & $\begin{array}{c}2^{\mathrm{a}} \text { Análise de } \\
\text { agrupamentos } \\
\text { (Parâmetros do } \\
\text { Meio Físico) }\end{array}$ & Total* \\
\hline $1^{\mathrm{a}}$ Ordem & 85 & - & 63 & 63 \\
\hline $2^{\mathrm{a}}$ Ordem & 100 & 34 & 30 & 34 \\
\hline $3^{\mathrm{a}}$ Ordem & 37 & 17 & 17 & 17 \\
\hline \multirow[t]{2}{*}{$4^{\mathrm{a}}$ Ordem } & 26 & 11 & 10 & 11 \\
\hline & 248 & & & 125 \\
\hline
\end{tabular}

* total de unidades consideradas para a realização da terceira análise de agrupamentos para o estabelecimento das unidades geoambientais. 
Figura 33 - Bacias hidrográficas da área de estudo antes das análises de agrupamentos.

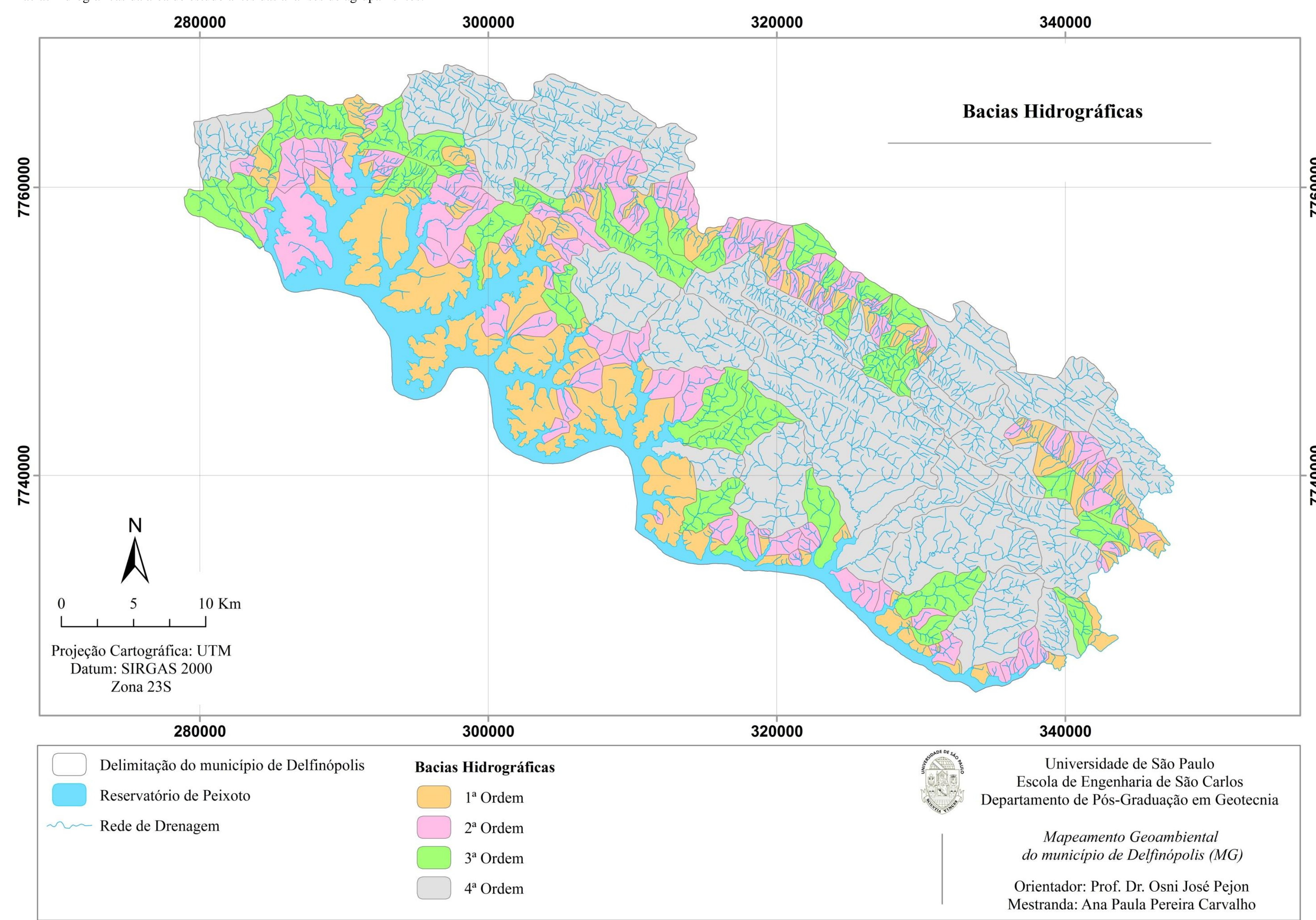



De 248 bacias que contemplam a área de estudo, após as duas primeiras análises de agrupamentos resultaram em 125 unidades, o que significa que ocorreu uma união de 49,6\% no número de unidades.

Para a delimitação das unidades geoambientais, conforme citado no item 4.2.3.3, a linha de fusão estabelecida foi de $80 \%$, visto que inicialmente para o estabelecimento destas unidades foi adotada uma linha de fusão de $20 \%$, com o objetivo de contemplar a união das bacias que apresentavam um maior nível de homogeneidade.

A Figura 34 apresenta o dendrograma que após as duas primeiras análises de agrupamentos foram unidas as 125 bacias hidrográficas para a delimitação das unidades geoambientais. 
Figura 34 - Dendrograma após as análises de agrupamentos para a delimitação das unidades geoambientais.

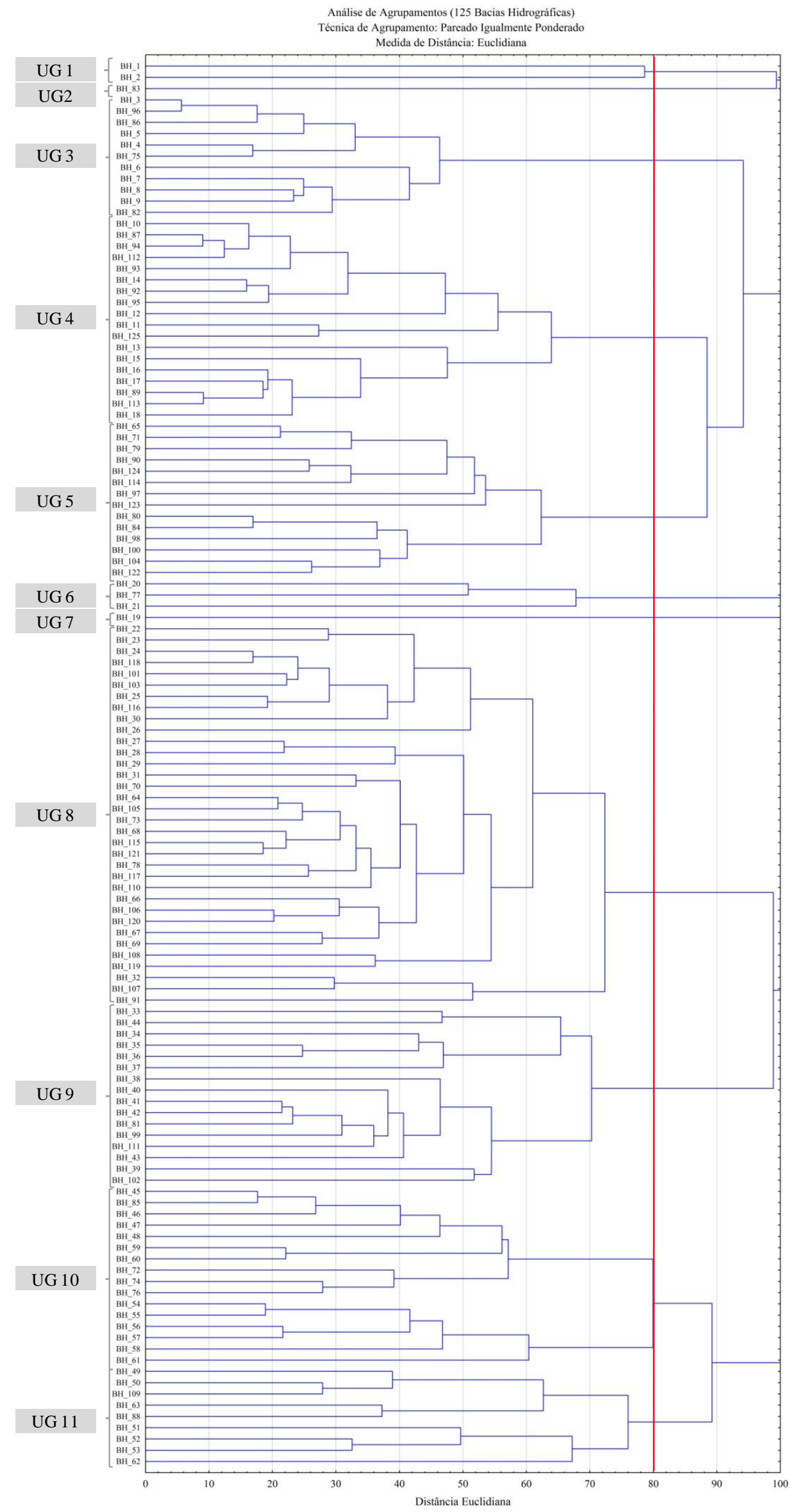


Foi realizada uma nova análise de agrupamentos considerando as onze unidades geoambientais e o percentual de área das classes do mapa de landforms elaborado por Magri (2013) (Figura 35). Esta análise foi efetuada na intenção de verificar a relação das unidades geoambientais com as formas de relevo da área de estudo, de modo a permitir a união das unidades que apresentam características semelhantes quanto a este atributo.

Figura 35 - Mapa de landforms.

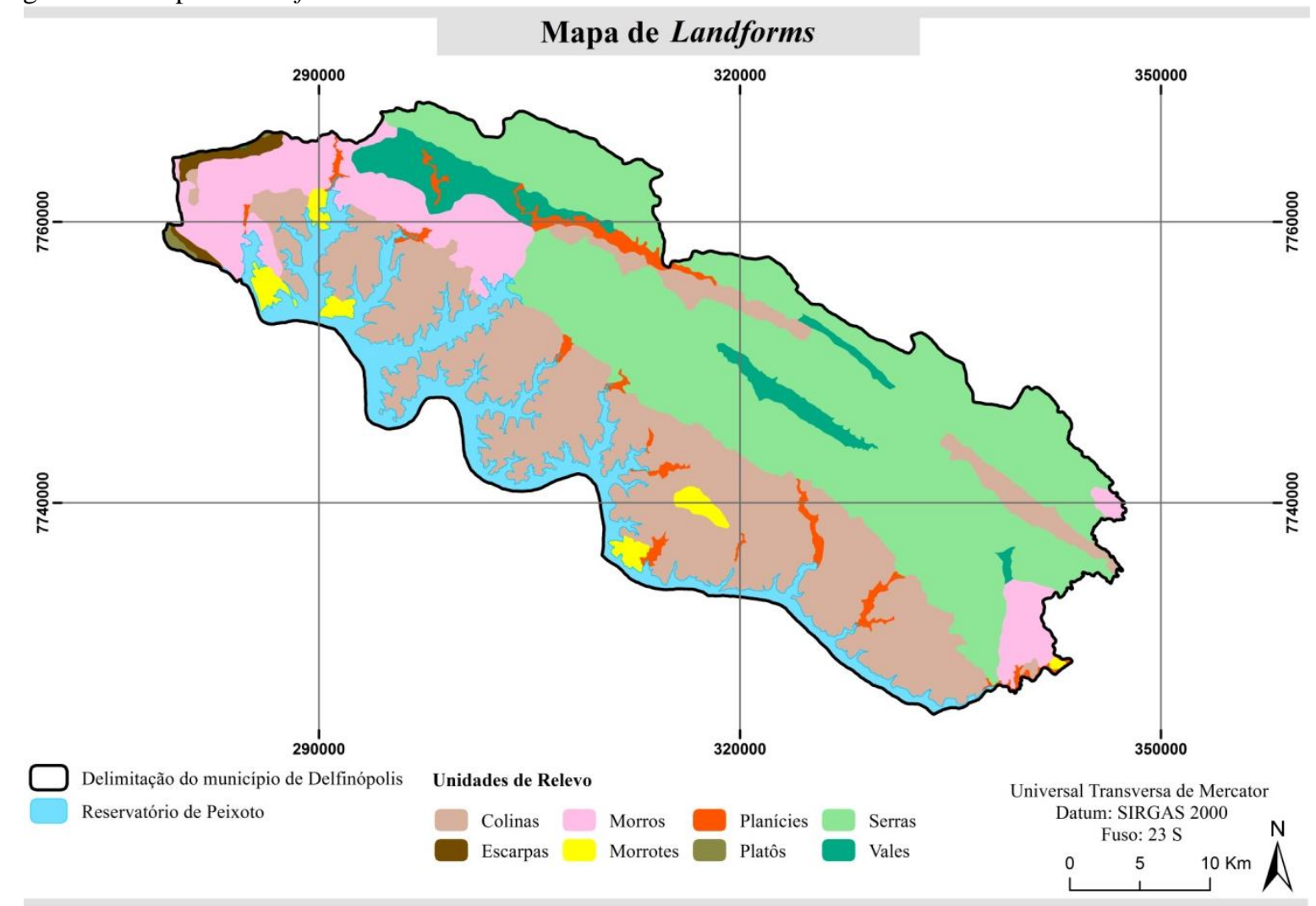

Fonte: Adaptado de Magri (2013).

Desse modo foi elaborado um dendrograma, no qual foi considerada a linha de fusão de $20 \%$, nota-se que os seguintes pares de unidades (UG 3 e UG 4) e (UG 5 e UG 10) apresentam grande similaridade quanto aos landforms, com isso as unidades foram agrupadas. Estes pares receberam uma nova nomenclatura sendo respectivamente, UG 9 e UG 4. Dessa forma, o número de unidades geoambientais resultou em nove.

As Figuras 36 e 37 apresentam respectivamente o dendrograma da análise de agrupamentos realizadas com as onze unidades levando em consideração o percentual de área das classes do mapa de landforms e o mapa das nove unidades geoambientais definidas após as análises estatísticas. 
Figura 36 - Dendrograma após a análise de agrupamentos das onze unidades geoambientais com relação às classes de landforms.

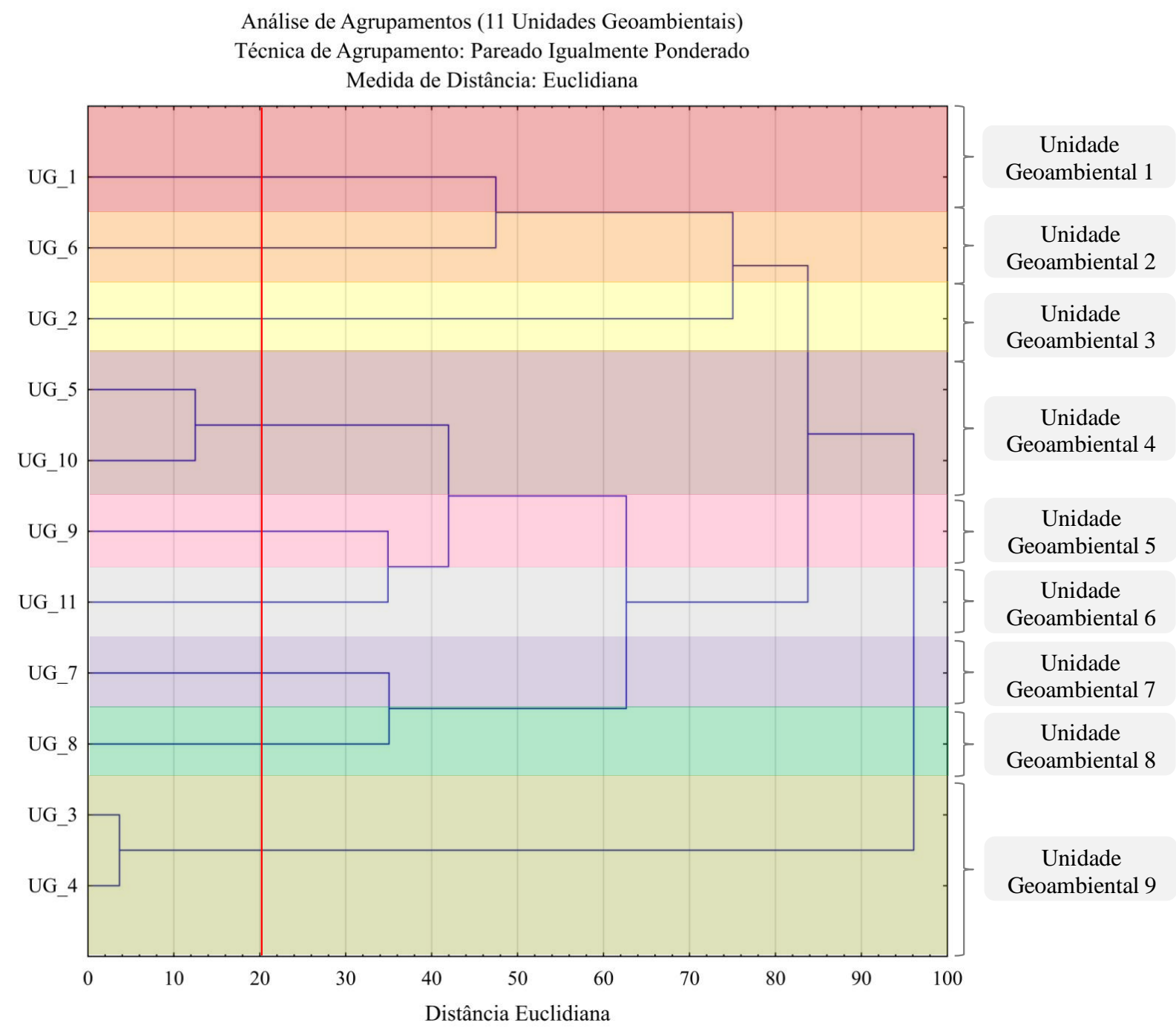

Comparando os limites das unidades geoambientais com as unidades de relevo (mapa de landforms) nota-se que a área de estudo apresenta formas de relevo bem características, com a presença de colinas na porção sul e serras na porção norte do município.

Pode-se observar que a espacialização das unidades geoambientais apresenta coerência com as unidades de relevo definidas por Magri (2013), os limites são semelhantes, porém não são idênticos, visto que o método utilizado para a compartimentação da área de estudo consistiu em técnicas muito distintas com relação às etapas executas para a elaboração do mapa de landforms. 
Figura 37 - Unidades geoambientais da área de estudo.

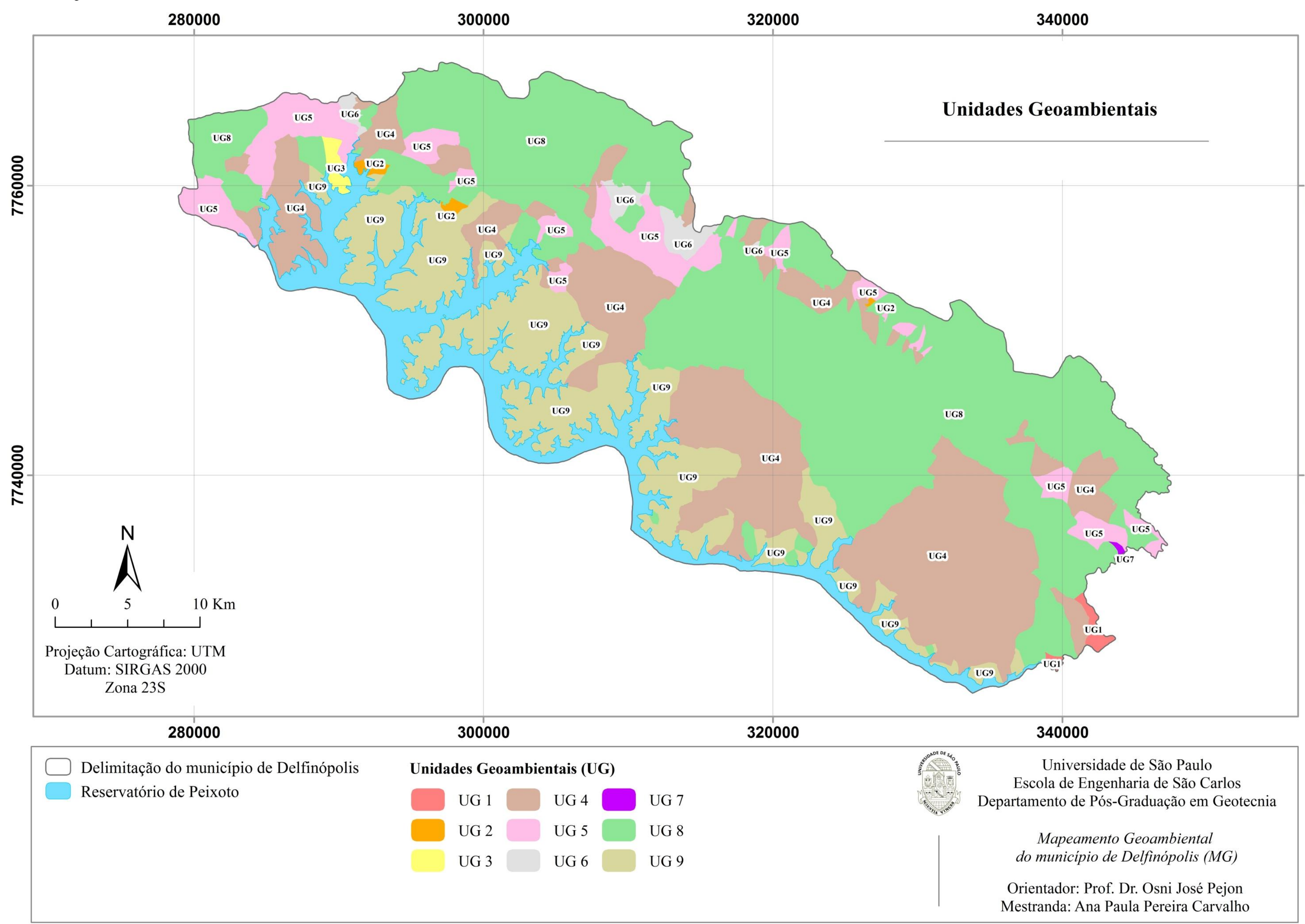





\subsection{Unidades geoambientais frente aos documentos temáticos e interpretativos}

As unidades geoambientais foram caracterizadas levando em consideração a análise dos atributos do meio físico, sendo eles: materiais inconsolidados (somente a textura) (MAGRI, 2013); substrato rochoso (COLLARES; GOMES, 2013); sistemas aquíferos (COLLARES; GOMES, 2013); e declividade.

Além dos mapas temáticos considerados, as unidades foram descritas também com relação a cinco cartas interpretativas, sendo elas: potencial à produção rural (SANTOS et al., 2013); suscetibilidade à erosão (MAGRI, 2013); suscetibilidade à inundação (SANTOS; COLLARES; COLLARES, 2013); escoamento superficial (MAGRI, 2010); e capacidade de infiltração (COLLARES et al., 2013).

Com relação à carta de potencial à produção rural, o mapeamento foi realizado considerando-se o potencial natural do solo à produção agropecuária, a vulnerabilidade dos terrenos à ocorrência de erosão, e as áreas inaptas (áreas urbanas, infraestruturas instaladas, estradas asfaltadas, declividades superiores a 45\%, áreas de preservação permanente, cobertura florestal, campo e campo arbustivo). Com base nestas análises, Santos et al. (2013) classificou a carta em quatro classes (baixo potencial; médio potencial; alto potencial à produção rural e áreas inaptas).

O restante dos produtos interpretativos analisados apresentam três classes (baixa, média e alta), com exceção da carta de capacidade de infiltração, que foi classificada com duas classes (baixa e média a alta).

Com base na tabulação cruzada realizada para quantificar o percentual de área de cada classe dos atributos físicos analisados, bem como o percentual de área das classes das cartas interpretativas consideradas, estão descritas a seguir as características das nove unidades geoambientais.

\section{Unidade Geoambiental 1}

A UG 1 apresenta uma área de 4,34 $\mathrm{km}^{2}$ o que corresponde a $0,35 \%$ da área do município. Esta unidade se situa em uma região em que os materiais inconsolidados são bem distribuídos, com o predomínio de silte e argila. 
A caracterização geomorfológica desta área é representada por morros na sua porção norte e por planícies na porção sul, correspondendo respectivamente a 48,38\% e 35,63\%. A declividade desta área é considerada média entre 10 a $30 \%$.

O substrato rochoso dominante é composto por gnaisse $(71,53 \%)$ pertencente às formações geológicas do Grupo Araxá. Com base nas características geológicas é uma unidade que não apresenta problemas naturais, como a ocorrência de processos erosivos.

A hidrogeologia é representa por um sistema aquífero gnáissico-granítico composto por gnaisse e rochas ultramáficas (COLLARES e GOMES, 2013). A Tabela 31 apresenta o percentual de área das classes dos atributos do meio físico utilizados na análise para a caracterização da unidade.

Tabela 31 - Percentual de área dos atributos do meio físico analisados na UG 1.

\begin{tabular}{|c|c|c|c|c|c|c|c|}
\hline \multirow{3}{*}{$\begin{array}{c}\text { Atributos } \\
\text { MI }\end{array}$} & \multicolumn{7}{|c|}{ Classes (\%) } \\
\hline & Ar & $\mathbf{S}$ & S e R & $\mathbf{D}(\mathbf{A r})$ & $\mathbf{D}(\mathbf{S})$ & $\mathbf{D}(\mathbf{S} / \mathbf{A})$ & $\mathbf{D}(\mathbf{A} / \mathbf{S} / \mathbf{A r})$ \\
\hline & 0,88 & 22,79 & - & - & 25,12 & 35,63 & 15,58 \\
\hline \multirow{2}{*}{ SR } & $\mathbf{C Q}$ & $\mathbf{G}$ & $\mathbf{X}$ & $\mathbf{Q}$ & $\mathbf{M}$ & $\mathbf{X} / \mathbf{Q}$ & \\
\hline & - & 71,53 & - & 0,54 & - & 27,93 & \\
\hline \multirow{2}{*}{ SA } & CD & \multicolumn{2}{|c|}{ GG } & \multicolumn{2}{|l|}{$\mathbf{Q t}$} & $\mathbf{X i}$ & \\
\hline & - & \multicolumn{2}{|c|}{71,53} & \multicolumn{2}{|l|}{0,54} & 27,93 & \\
\hline \multirow{2}{*}{$\mathrm{DE}$} & $<10 \%$ & \multicolumn{2}{|c|}{10 a $30 \%$} & \multicolumn{2}{|l|}{$>\mathbf{3 0 \%}$} & & \\
\hline & 36,48 & \multicolumn{2}{|c|}{39,82} & 23,70 & & & \\
\hline \multicolumn{4}{|l|}{ Legenda } & \multicolumn{2}{|c|}{ SR: Substrato Rochoso } & \multicolumn{2}{|c|}{ SA: Sistemas Aquíferos } \\
\hline \multicolumn{4}{|c|}{ MI: Materiais Inconsolidados (textura) } & \multicolumn{2}{|c|}{ CQ: Coberturas Quaternárias } & \multicolumn{2}{|c|}{ CD: Cobertura Detrítica } \\
\hline \multicolumn{4}{|l|}{ Ar: Areia } & \multicolumn{2}{|l|}{ G: Gnaisse } & \multicolumn{2}{|c|}{ GG: Gnáissico-granítico } \\
\hline \multicolumn{4}{|l|}{ S: Silte } & \multicolumn{2}{|l|}{$\mathrm{X}$ : Xisto } & \multicolumn{2}{|c|}{ Qt: Quartizítico } \\
\hline \multicolumn{4}{|c|}{ S e R: Silte e Rocha } & \multicolumn{2}{|l|}{ Q: Quartzito } & \multicolumn{2}{|c|}{ Xi: Xistoso } \\
\hline \multicolumn{4}{|c|}{ D(Ar): Distribuída de Areia } & \multicolumn{2}{|l|}{ M: Milonito } & \multicolumn{2}{|c|}{ DE: Declividade } \\
\hline \multicolumn{4}{|c|}{ D(S): Distribuída de Silte } & \multirow{3}{*}{\multicolumn{2}{|c|}{ X/Q: Xisto e Quartzito }} & \multirow{3}{*}{\multicolumn{2}{|c|}{$\begin{array}{l}\text { - classe não encontrada na } \\
\text { área }\end{array}$}} \\
\hline \multicolumn{4}{|c|}{ D(S/A): Distribuída de Silte e Argila } & & & & \\
\hline $\mathrm{D}(\mathrm{A} / \mathrm{S} / \mathrm{Ar}): \mathrm{D}$ & suída de $A$ & a, Silte & reia & & & & \\
\hline
\end{tabular}

A UG1 quanto ao potencial à produção rural apresenta 40,52\% do seu contingente ocupada por áreas impróprias ao uso, no entanto 37,20\% de sua área se mostram em médio potencial para o desenvolvimento rural.

Com relação às suscetibilidades, a UG1 conta com 55,76\% de sua área sendo uma região de baixa suscetibilidade a predisposição de feições erosivas, enquanto que grande parte desta unidade $(75,73 \%)$ se enquadra em média suscetibilidade a processo de inundação, visto 
A UG 2 apresenta na sua maioria terrenos com declividades baixas, visto que estas áreas estão localizadas as margem do Rio Grande. A Tabela 33 mostra a área (\%) das classes dos atributos analisados.

Tabela 33 - Percentual de área dos atributos do meio físico analisados na UG 2.

\begin{tabular}{|c|c|c|c|c|c|c|c|}
\hline Atributos & \multicolumn{7}{|c|}{ Classes (\%) } \\
\hline \multirow{2}{*}{ MI } & Ar & $\mathbf{S}$ & S e R & $\mathbf{D}(\mathbf{A r})$ & $\mathbf{D}(\mathbf{S})$ & $\mathbf{D}(\mathbf{S} / \mathbf{A})$ & $\mathbf{D}(\mathbf{A} / \mathbf{S} / \mathbf{A r})$ \\
\hline & 64,36 & 3,82 & 1,34 & 27,24 & - & 3,24 & - \\
\hline \multirow{2}{*}{ SR } & CQ & $\mathbf{G}$ & $\mathbf{X}$ & $\mathbf{Q}$ & $\mathbf{M}$ & $\mathbf{X} / \mathbf{Q}$ & \\
\hline & - & 0,43 & 5,07 & 2,00 & 0,10 & 92,40 & \\
\hline \multirow{2}{*}{ SA } & CD & \multicolumn{2}{|c|}{ GG } & \multicolumn{2}{|r|}{ Qt } & \multicolumn{2}{|l|}{$\mathbf{X i}$} \\
\hline & - & \multicolumn{2}{|c|}{0,43} & \multicolumn{2}{|r|}{2,10} & 97,47 & \\
\hline \multirow{2}{*}{$\mathrm{DE}$} & $<10 \%$ & \multicolumn{2}{|c|}{10 a $30 \%$} & \multicolumn{2}{|l|}{$>\mathbf{3 0 \%}$} & & \\
\hline & 52,46 & \multicolumn{2}{|c|}{35,99} & \multicolumn{2}{|l|}{11,55} & & \\
\hline \multicolumn{6}{|c|}{ Legenda } & \multicolumn{2}{|c|}{ SA: Sistemas Aquíferos } \\
\hline \multicolumn{4}{|c|}{ MI: Materiais Inconsolidados (textura) } & CQ: & \multirow[t]{2}{*}{ Coberturas } & \multicolumn{2}{|c|}{ CD: Cobertura Detrítica } \\
\hline \multicolumn{4}{|c|}{ Ar: Areia } & Quaternárias & & GG: Gnáissic & -granítico \\
\hline \multicolumn{4}{|l|}{ S: Silte } & \multicolumn{2}{|l|}{ G: Gnaisse } & Qt: Quartizíti & \\
\hline \multicolumn{4}{|c|}{ S e R: Silte e Rocha } & \multicolumn{2}{|l|}{$\mathrm{X}$ : Xisto } & Xi: Xistoso & \\
\hline \multicolumn{4}{|c|}{$\mathrm{D}(\mathrm{Ar})$ : Distribuída de Areia } & \multicolumn{2}{|l|}{ Q: Quartzito } & DE: Declivid: & \\
\hline \multicolumn{4}{|c|}{ D(S): Distribuída de Silte } & \multicolumn{2}{|l|}{ M: Milonito } & - classe não & contrada na \\
\hline \multicolumn{4}{|c|}{ D(S/A): Distribuída de Silte e Argila } & \multirow{2}{*}{\multicolumn{2}{|c|}{ X/Q: Xisto e Quartzito }} & área & \\
\hline $\mathrm{D}(\mathrm{A} / \mathrm{S} / \mathrm{Ar}): \mathrm{Di}$ & lída de $\mathrm{A}$ & & & & & & \\
\hline
\end{tabular}

A UG 2 apresenta mais de $75 \%$ de sua área sendo ocupada por áreas inaptas a produção do meio rural. A segunda maior classe representa a área com média produtividade correspondendo a $16,60 \%\left(0,50 \mathrm{~km}^{2}\right)$.

Esta unidade com relação aos processos ambientais analisados apresenta média suscetibilidade à ocorrência de erosão e inundação, correspondendo respectivamente a $60,94 \%$ e 51,36\%. Um dos fatores que se relacionam com a tendência ao surgimento ou agravamento das feições erosivas é o material inconsolidado com textura arenosa que representa $64,36 \%$ da área da unidade.

O escoamento superficial desta unidade geoambiental é considerado baixo, por sua vez a capacidade de infiltração varia de média a alta, contribuindo desta forma com o abastecimento do aquífero da área, sendo o predominante o xistoso, correspondendo a mais de 97\%. Os percentuais de área dos atributos interpretativos analisados para a UG 2 se encontram dispostos na Tabela 34. 
Tabela 34 - Percentual de área dos produtos interpretativos do meio físico analisados na UG 2.

\begin{tabular}{|c|c|c|c|c|}
\hline Atributos & \multicolumn{4}{|c|}{ Classes (\%) } \\
\hline \multirow{2}{*}{ PPR } & Baixa & Média & Alta & Áreas Inaptas \\
\hline & - & 16,60 & 4,60 & 78,80 \\
\hline \multirow{2}{*}{ SE } & Baixa & Média & Alta & \\
\hline & 38,25 & 60,94 & 0,81 & \\
\hline \multirow{2}{*}{ SI } & Baixa & Média & Alta & \\
\hline & 24,32 & 51,36 & 24,32 & \\
\hline \multirow{2}{*}{ PES } & Baixa & Média & Alta & \\
\hline & 55,12 & 28,27 & 16,61 & \\
\hline \multirow{2}{*}{$\mathrm{CI}$} & Baixa & Média a Alta & & \\
\hline & 8,40 & 91,60 & & \\
\hline \multicolumn{5}{|l|}{ Legenda } \\
\hline \multirow{2}{*}{\multicolumn{2}{|c|}{$\begin{array}{l}\text { PPR: Potencial à produção rural } \\
\text { AA: Aptidão agrícola }\end{array}$}} & \multicolumn{3}{|c|}{ SI: Suscetibilidade à inundação } \\
\hline & & \multirow{2}{*}{\multicolumn{3}{|c|}{$\begin{array}{l}\text { ES: Potencial ao escoamento superficial } \\
\text { CI: Capacidade de infiltracão }\end{array}$}} \\
\hline \multicolumn{2}{|c|}{ SE: Suscetibilidade à erosão } & & & \\
\hline
\end{tabular}

\section{Unidade Geoambiental 3}

A UG 3 se encontra situada na porção oeste do município, com uma área muito semelhante da UG 1, atingindo $4,31 \mathrm{~km}^{2}$ de superfície. A composição granulométrica do material inconsolidado que compõe a maior parte da área é distribuída de argila, silte e areia, que corresponde a 3,08 $\mathrm{km}^{2}$, estando presente em locais em que o relevo é caracterizado por morrotes e morros. A segunda classe mais abundante é composta principalmente por solos arenosos que compreende quase $20 \%$ da área. Estes materiais estão localizados em áreas onde as declividades são inferiores a $10 \%$.

Os sistemas aquíferos desta unidade são gnáissico-granítico e xistoso, oriundos do substrato rochoso composto por gnaisse e xisto com intercalações de quartzito, ambas litologias estão representadas nas formações geológicas do Grupo Araxá. A Tabela 35 apresenta dados quantitativos (área em percentual) das classes dos atributos do meio físico analisados para a UG 3.

Esta unidade apresenta $26,81 \%$ da sua área apresenta alta produtividade rural. Um ponto muito positivo sobre esta unidade é a sua baixa predisposição a eventos naturais, como erosão e inundação, visto que mais da metade de sua área $(59,07 \%)$ apresenta baixa incidência a ocorrência de feições erosivas, enquanto que, com relação à inundação, toda a área mostrase com características físicas e geológicas que não predispõem a este tipo de evento. 
Tabela 35 - Percentual de área dos atributos do meio físico analisados na UG 3.

\begin{tabular}{|c|c|c|c|c|c|c|c|}
\hline Atributos & \multicolumn{7}{|c|}{ Classes (\%) } \\
\hline \multirow{2}{*}{ MI } & Ar & $\mathbf{S}$ & S e R & $\mathbf{D}(\mathbf{A r})$ & $\mathbf{D}(\mathbf{S})$ & $\mathbf{D}(\mathbf{S} / \mathbf{A})$ & $\mathbf{D}(\mathbf{A} / \mathbf{S} / \mathbf{A r})$ \\
\hline & 19,84 & 8,62 & - & 0,15 & - & - & 71,39 \\
\hline \multirow{2}{*}{ SR } & CQ & G & $\mathbf{X}$ & $\mathbf{Q}$ & $\mathbf{M}$ & $\mathbf{X} / \mathbf{Q}$ & \\
\hline & - & 52,57 & 8,62 & 18,21 & - & 20,60 & \\
\hline \multirow{2}{*}{ SA } & CD & \multicolumn{2}{|c|}{ GG } & \multicolumn{2}{|c|}{$\mathbf{Q t}$} & \multicolumn{2}{|l|}{$\mathbf{X i}$} \\
\hline & - & \multicolumn{2}{|c|}{52,57} & \multicolumn{2}{|c|}{18,21} & 29,22 & \\
\hline \multirow{2}{*}{ DE } & $<10 \%$ & \multicolumn{2}{|c|}{10 a $30 \%$} & \multicolumn{2}{|l|}{$>\mathbf{3 0 \%}$} & & \\
\hline & 61,00 & \multicolumn{2}{|c|}{31,72} & \multicolumn{2}{|l|}{7,28} & & \\
\hline \multicolumn{6}{|c|}{ SR: Substrato Rochoso } & \multicolumn{2}{|c|}{ SA: Sistemas Aquíferos } \\
\hline \multicolumn{4}{|c|}{ MI: Materiais Inconsolidados (textura) } & \multicolumn{2}{|c|}{$\begin{array}{l}\text { SR: Substrato Rochoso } \\
\text { CQ: } \quad \text { Coberturas }\end{array}$} & \multicolumn{2}{|c|}{ CD: Cobertura Detrítica } \\
\hline \multirow{2}{*}{\multicolumn{4}{|c|}{$\begin{array}{l}\text { Ar: Areia } \\
\text { S: Silte }\end{array}$}} & \multirow{2}{*}{\multicolumn{2}{|c|}{ Quaternárias }} & \multicolumn{2}{|c|}{ GG: Gnáissico-granítico } \\
\hline \multirow{2}{*}{\multicolumn{4}{|c|}{$\begin{array}{l}\text { S: Silte } \\
\text { S e R: Sil }\end{array}$}} & & & \multicolumn{2}{|c|}{ Qt: Quartizítico } \\
\hline & & & & \multirow{2}{*}{\multicolumn{2}{|c|}{ Q: Quartzito }} & \multicolumn{2}{|l|}{ Xi: Xistoso } \\
\hline \multicolumn{4}{|c|}{ D(Ar): Distribuída de Areia } & & & \multirow{3}{*}{\multicolumn{2}{|c|}{$\begin{array}{l}\text { DE: Declividade } \\
\text { - classe não encontrada na } \\
\text { área }\end{array}$}} \\
\hline \multicolumn{4}{|c|}{ D(S): Distribuída de Silte } & \multicolumn{2}{|l|}{ M: Milonito } & & \\
\hline \multirow{2}{*}{\multicolumn{4}{|c|}{$\begin{array}{l}\text { D(S/A): Distribuída de Silte e Argila } \\
\text { D(A/S/Ar): Distribuída de Argila, Silte e Areia }\end{array}$}} & X/Q: Xisto e Q & Quartzito & & \\
\hline & & & & & & & \\
\hline
\end{tabular}

Da mesma forma que a unidade anterior, a UG 3 apresenta um baixo escoamento superficial o que consequentemente favorece a percolação de água no terreno. Dessa forma, 91,15\% da área da unidade se enquadram no intervalo de média a alta capacidade de infiltração. A área em percentual dos atributos utilizados para a análise da UG 3 se apresenta na Tabela 36.

Tabela 36 - Percentual de área dos produtos interpretativos do meio físico analisados na UG 3.

\begin{tabular}{c|cccc}
\hline Atributos & \multicolumn{4}{|c}{ Classes (\%) } \\
\hline \multirow{2}{*}{ PPR } & Baixa & Média & Alta & Áreas Inaptas \\
& - & 21,39 & 26,81 & 51,80 \\
\hline \multirow{2}{*}{ SE } & Baixa & Média & Alta & \\
& 59,07 & 40,68 & 0,25 & \\
\hline \multirow{2}{*}{ SI } & Baixa & Média & Alta & \\
& 100,00 & - & Alta & \\
& Baixa & Média & 5,79 & \\
\hline \multirow{2}{*}{ PES } & 72,73 & 21,48 & & \\
& Baixa & Média a Alta & & \\
\hline \multirow{2}{*}{ CI } & 8,85 & 91,15 & \\
\end{tabular}

Legenda

PPR: Potencial à produção rural

AA: Aptidão agrícola

SE: Suscetibilidade à erosão
SI: Suscetibilidade à inundação

ES: Potencial ao escoamento superficial

CI: Capacidade de infiltração 


\section{Unidade Geoambiental 4}

A UG 4 abrange aproximadamente uma área de $349,08 \mathrm{~km}^{2}$, correspondendo $28 \%$ da área do município. O material inconsolidado desta unidade é composto por solos cuja fração granulométrica é a areia, correspondendo uma área de 152,29 km². A maior parte dos materiais se encontra em regiões de relevo colinoso que não ultrapassam 10\% de declividade.

O substrato rochoso predominante são os xistos com intercalações de quartzitos pertencentes ao Grupo Canastra e Araxá. A segunda classe mais abundante é composta por rochas gnáissicas, localizadas na porção sul da unidade.

Com relação aos aspectos hidrogeológicos, o sistema aquífero que representa a unidade é dividido em duas maiores classes, que juntas ultrapassam $65 \%$ da área, visto que a primeira é representada pelos aquíferos xistosos $(36,10 \%)$ e a segunda pelos sistemas gnáissico-granítico $(32,43 \%)$ (Tabela 37).

Tabela 37 - Percentual de área dos atributos do meio físico analisados na UG 4.

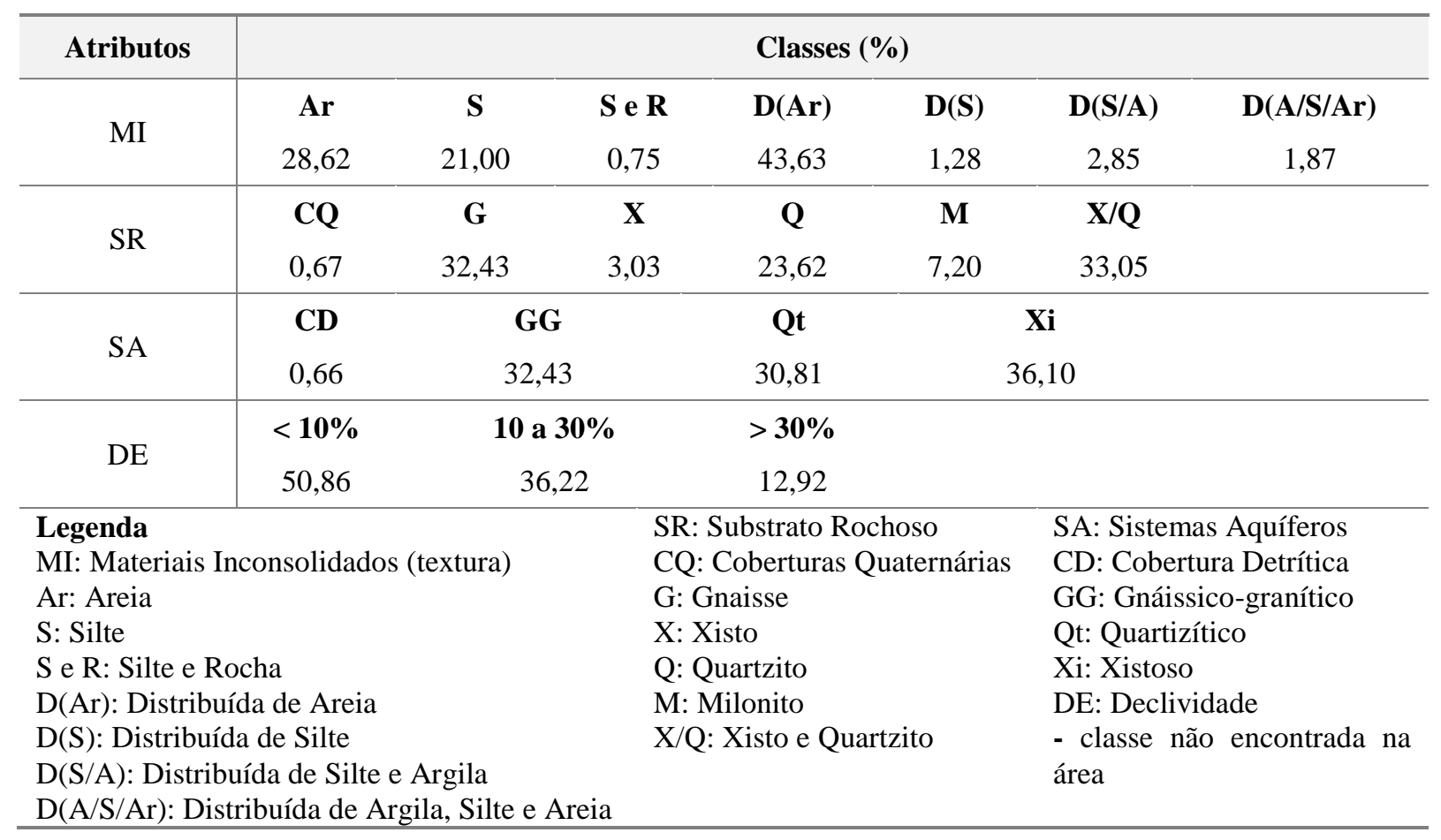

Com relação à produção agrícola a UG 4 abrange uma área de 126,57 km² (36,19\% da área total da unidade) com médio potencial (Tabela 38). Esta unidade apresenta média suscetibilidade à erosão, principalmente nas regiões em que a areia é a fração granulométrica 
predominante, sendo que nesta unidade este material abrange uma área de $252,20 \mathrm{~km}^{2}$, o que corresponde $72,25 \%$ da área total da UG 4.

Ainda sobre a suscetibilidade desta unidade, mais de $78 \%$ da sua área apresenta uma tendência a ser inundada, devido grande parte estar situada em declividades baixas (inferiores a $10 \%$ ) as margens do reservatório de Peixoto, podendo ser consideradas como planícies de inundação.

O escoamento de água desta área é considerado baixo, um dos motivos é o material inconsolidado que a compõe, cuja textura predominante é areia, outro fator que contribui para tal situação é a declividade, visto que a unidade apresenta grande porção da sua área com declividades baixas, o que possibilita uma maior infiltração de água no solo, sendo que o solo apresenta propriedades físicas que favorecem a infiltração (capacidade de infiltração varia de média a alta, correspondendo a 75,39\%) diminuindo dessa forma o potencial de escoamento.

Tabela 38 - Percentual de área dos produtos interpretativos do meio físico analisados na UG4.

\begin{tabular}{|c|c|c|c|c|}
\hline Atributos & \multicolumn{4}{|c|}{ Classes (\%) } \\
\hline \multirow{2}{*}{ PPR } & Baixa & Média & Alta & Áreas Inaptas \\
\hline & 0,01 & 36,19 & 7,87 & 55,93 \\
\hline \multirow{2}{*}{ SE } & Baixa & Média & Alta & \\
\hline & 30,71 & 68,91 & 0,38 & \\
\hline \multirow{2}{*}{ SI } & Baixa & Média & Alta & \\
\hline & 9,20 & 78,28 & 12,52 & \\
\hline \multirow{2}{*}{ PES } & Baixa & Média & Alta & \\
\hline & 56,01 & 34,38 & 9,61 & \\
\hline \multirow{2}{*}{ CI } & Baixa & Média a Alta & & \\
\hline & 24,61 & 75,39 & & \\
\hline \multicolumn{5}{|l|}{ Legenda } \\
\hline \multirow{3}{*}{\multicolumn{2}{|c|}{$\begin{array}{l}\text { PPR: Potencial à produção rural } \\
\text { AA: Aptidão agrícola } \\
\text { SE: Suscetibilidade à erosão }\end{array}$}} & & \multirow{3}{*}{\multicolumn{2}{|c|}{$\begin{array}{l}\text { SI: Suscetibilidade à inundação } \\
\text { ES: Potencial ao escoamento superficial } \\
\text { CI: Capacidade de infiltração }\end{array}$}} \\
\hline & & & & \\
\hline & & & & \\
\hline
\end{tabular}

\section{Unidade Geoambiental 5}

Com uma área de $90,64 \mathrm{~km}^{2}$ (7,27\% do total), o material inconsolidado de maior ocorrência está situado em terrenos em que a textura dos solos é mais siltosa. Os materiais estão distribuídos em sua grande maioria em regiões que apresentam declividades médias a altas, em relevos de serras e morros. 
Na unidade o substrato rochoso predominante é o xisto, correspondendo quase $50 \%$ da sua área total, desse modo o sistema aquífero dominante é o xistoso $(58,74 \%)$. O segundo sistema aquífero de maior relevância é o quartzítico, oriundo do substrato rochoso que compõe a unidade.

A Tabela 39 apresenta o percentual de área das classes dos atributos do meio físico utilizados para a caracterização da UG 5.

Tabela 39 - Percentual de área dos atributos do meio físico analisados na UG 5.

\begin{tabular}{|c|c|c|c|c|c|c|c|}
\hline Atributos & \multicolumn{7}{|c|}{ Classes $(\%)$} \\
\hline \multirow{2}{*}{ MI } & Ar & $\mathbf{S}$ & S e R & $\mathbf{D}(\mathbf{A r})$ & $\mathbf{D}(\mathbf{S})$ & $\mathbf{D}(\mathbf{S} / \mathbf{A})$ & $\mathbf{D}(\mathbf{A} / \mathbf{S} / \mathbf{A r})$ \\
\hline & 24,73 & 56,03 & 13,71 & 1,58 & - & 3,23 & 0,72 \\
\hline \multirow{2}{*}{$\mathrm{SR}$} & CQ & $\mathbf{G}$ & $\mathbf{X}$ & $\mathbf{Q}$ & $\mathbf{M}$ & $\mathbf{X} / \mathbf{Q}$ & \\
\hline & 2,78 & 0,05 & 49,75 & 24,60 & 13,83 & 8,99 & \\
\hline \multirow{2}{*}{ SA } & CD & \multicolumn{2}{|c|}{ GG } & \multicolumn{2}{|c|}{ Qt } & \multicolumn{2}{|c|}{$\mathbf{X i}$} \\
\hline & 2,78 & \multicolumn{2}{|c|}{0,05} & \multicolumn{2}{|c|}{38,43} & \multicolumn{2}{|c|}{58,74} \\
\hline \multirow{2}{*}{$\mathrm{DE}$} & $<10 \%$ & \multicolumn{2}{|c|}{10 a $30 \%$} & \multicolumn{2}{|l|}{$>\mathbf{3 0} \%$} & & \\
\hline & 25,45 & \multicolumn{2}{|c|}{40,49} & \multicolumn{2}{|l|}{34,06} & & \\
\hline \multicolumn{4}{|l|}{ Legenda } & \multicolumn{2}{|c|}{ SR: Substrato Rochoso } & \multicolumn{2}{|c|}{ SA: Sistemas Aquíferos } \\
\hline \multicolumn{4}{|c|}{ MI: Materiais Inconsolidados (textura) } & CQ: & \multirow[t]{2}{*}{ Coberturas } & \multicolumn{2}{|c|}{ CD: Cobertura Detrítica } \\
\hline \multicolumn{4}{|c|}{ Ar: Areia } & Quaternárias & & \multicolumn{2}{|c|}{ GG: Gnáissico-granítico } \\
\hline \multicolumn{4}{|l|}{ S: Silte } & \multicolumn{2}{|l|}{ G: Gnaisse } & \multicolumn{2}{|c|}{ Qt: Quartizítico } \\
\hline \multicolumn{4}{|c|}{ S e R: Silte e Rocha } & \multicolumn{2}{|l|}{$\mathrm{X}$ : Xisto } & \multicolumn{2}{|c|}{$\mathrm{Xi}$ : Xistoso } \\
\hline \multicolumn{4}{|c|}{$\mathrm{D}(\mathrm{Ar})$ : Distribuída de Areia } & \multicolumn{2}{|l|}{ Q: Quartzito } & \multicolumn{2}{|c|}{ DE: Declividade } \\
\hline \multicolumn{4}{|c|}{ D(S): Distribuída de Silte } & \multicolumn{2}{|l|}{ M: Milonito } & \multirow{2}{*}{\multicolumn{2}{|c|}{$\begin{array}{l}\text { - classe não encontrada na } \\
\text { área }\end{array}$}} \\
\hline $\mathrm{D}(\mathrm{S} / \mathrm{A}):$ Distri & de Silte & gila & & X/Q: Xisto e & Quartzito & & \\
\hline & iída de A & Silte e & & & & & \\
\hline
\end{tabular}

A UG 5 apresenta 14,56 km² de sua área com alta potencialidade à produção rural, o que corresponde a 16,06\%. No entanto mesmo apresentando alto potencial ao desenvolvimento rural, a unidade apresenta $80,20 \%$ de áreas inaptas.

A suscetibilidade ao surgimento de feições erosivas na unidade é baixa nas regiões em que predomina o silte como material inconsolidado dominante, as áreas que apresentam alguma sensibilidade à ocorrência de erosão são compostas por areia, e ainda são locais em que apresentam altos declives.

A unidade é caracterizada com média suscetibilidade à inundação $\left(64,65 \mathrm{~km}^{2}\right)$, pois a região noroeste da área é formada por planícies, sendo que a baixa declividade desta unidade de relevo juntamente com o tipo de solo contribui para tal processo. Desse modo, esta área apresenta médio escoamento superficial, o que consequentemente resulta em mais de $70 \%$ da 
área ser caracterizada com alta capacidade de infiltração. Os dados percentuais de área dos atributos analisados para a UG 5 são apresentados na Tabela 40.

Tabela 40 - Percentual de área dos produtos interpretativos do meio físico analisados na UG5.

\begin{tabular}{|c|c|c|c|c|}
\hline Atributos & \multicolumn{4}{|c|}{ Classes (\%) } \\
\hline \multirow{2}{*}{ PPR } & Baixa & Média & Alta & Áreas Inaptas \\
\hline & 0,06 & 3,68 & 16,06 & 80,20 \\
\hline \multirow{2}{*}{ SE } & Baixa & Média & Alta & \\
\hline & 50,22 & 49,52 & 0,26 & \\
\hline \multirow{2}{*}{ SI } & Baixa & Média & Alta & \\
\hline & 9,59 & 71,22 & 19,19 & \\
\hline \multirow{2}{*}{ PES } & Baixa & Média & Alta & \\
\hline & 27,15 & 46,30 & 26,55 & \\
\hline \multirow{2}{*}{$\mathrm{CI}$} & Baixa & Média a Alta & & \\
\hline & 72,97 & 27,03 & & \\
\hline \multicolumn{5}{|l|}{ Legenda } \\
\hline \multirow{2}{*}{\multicolumn{2}{|c|}{$\begin{array}{l}\text { PPR: Potencial à produção rural } \\
\text { AA: Aptidão agrícola }\end{array}$}} & & \multirow{3}{*}{\multicolumn{2}{|c|}{$\begin{array}{l}\text { SI: Suscetibilidade à inundação } \\
\text { ES: Potencial ao escoamento superficial } \\
\text { CI: Capacidade de infiltração }\end{array}$}} \\
\hline & & & & \\
\hline \multicolumn{2}{|c|}{ SE: Suscetibilidade à erosão } & & & \\
\hline
\end{tabular}

\section{Unidade Geoambiental 6}

Apresenta uma área de aproximadamente $14,40 \mathrm{~km}^{2}$ (1,15\% da área do município), na UG 6 a composição granulométrica do material inconsolidado que compõe a maior parte da área é silte, que corresponde a $6,37 \mathrm{~km}^{2}$, estando presente em locais em que o relevo é caracterizado por serras. A segunda classe mais abundante ocorre em regiões de planícies e é composta principalmente por solos que apresentam uma distribuição maior de partículas de silte e argila $\left(4,35 \mathrm{~km}^{2}\right)$.

O substrato rochoso dominante é o milonito que corresponde $5,90 \mathrm{~km}^{2}$, a segunda litologia que representa a unidade é a classe de coberturas quaternárias abrangendo uma área de 4,92 $\mathrm{km}^{2}$. Com base nas rochas presentes na unidade os sistemas aquíferos se dividem em duas classes predominantes, sendo respectivamente o quartizítico e as coberturas detríticas (Tabela 41). 
A unidade apresenta um moderado escoamento superficial, enquanto que a predisposição da área para acontecimentos de inundação é relativamente alta, visto que quase metade da unidade $(48,93 \%)$ apresenta alta suscetibilidade para a ocorrência deste evento. Nesta unidade $93,44 \%\left(13,45 \mathrm{~km}^{2}\right)$ da sua área possui baixa capacidade de infiltração, isso é devido à composição textural do solo e da inclinação da superfície da UG 6.

\section{Unidade Geoambiental 7}

A UG 7 é considerada a menor unidade com $0,44 \mathrm{~km}^{2}(0,04 \%$ do total $)$, e ela se diferencia das outras unidades pela predominância de mais de $90 \%$ de uma classe dentre a maioria dos atributos analisados (aspecto textural dos materiais inconsolidados; substrato rochoso; e sistemas aquíferos).

Com relação ao aspecto textural dos materiais inconsolidados, a classe que se destaca com $93,68 \%\left(0,41 \mathrm{~km}^{2}\right)$ é o silte. A classe que representa o substrato rochoso da unidade são os xistos com intercalações de quartzitos pertencentes às formações geológicas do Grupo Araxá. Baseado nos aspectos geológicos da unidade, o sistema aquífero de maior relevância é o xistoso $(92,78 \%)$.

A unidade apresenta relevo de serras, em que a declividade pode ser considerada de média a alta, variando entre 10 a $30 \%$ (Tabela 43).

Tabela 43 - Percentual de área dos atributos do meio físico analisados na UG 7.

\begin{tabular}{|c|c|c|c|c|c|c|c|}
\hline Atributos & \multicolumn{7}{|c|}{ Classes (\%) } \\
\hline \multirow{2}{*}{ MI } & Ar & $\mathbf{S}$ & S e R & $\mathbf{D}(\mathbf{A r})$ & $\mathbf{D}(\mathbf{S})$ & $\mathbf{D}(\mathbf{S} / \mathbf{A})$ & $\mathbf{D}(\mathbf{A} / \mathbf{S} / \mathbf{A r})$ \\
\hline & 6,32 & 93,68 & - & - & - & - & - \\
\hline \multirow{2}{*}{ SR } & CQ & G & $\mathbf{X}$ & $\mathbf{Q}$ & M & $\mathrm{X} / \mathrm{Q}$ & \\
\hline & - & - & - & 7,22 & - & 92,78 & \\
\hline \multirow{2}{*}{ SA } & CD & \multicolumn{2}{|c|}{ GG } & \multicolumn{2}{|c|}{ Qt } & \multicolumn{2}{|c|}{$\mathbf{X i}$} \\
\hline & - & \multicolumn{2}{|c|}{ - } & \multicolumn{2}{|c|}{7,22} & \multicolumn{2}{|c|}{92,78} \\
\hline \multirow{2}{*}{$\mathrm{DE}$} & $<10 \%$ & & & & & \\
\hline & 40,02 & & & \multicolumn{2}{|l|}{8,55} & & \\
\hline \multicolumn{4}{|l|}{ Legenda } & \multicolumn{2}{|c|}{ SR: Substrato Rochoso } & \multicolumn{2}{|c|}{ SA: Sistemas Aquíferos } \\
\hline \multicolumn{4}{|c|}{ MI: Materiais Inconsolidados (textura) } & CQ: & Coberturas & CD: Cobe & ra Detrítica \\
\hline \multicolumn{4}{|c|}{ Ar: Areia } & Quaternárias & & GG: Gnái & o-granítico \\
\hline \multicolumn{4}{|l|}{ S: Silte } & G: Gnaisse & & Qt: Quarti & \\
\hline \multicolumn{4}{|c|}{ S e R: Silte e Rocha } & $\mathrm{X}$ : Xisto & & Xi: Xistos & \\
\hline \multicolumn{4}{|c|}{ D(Ar): Distribuída de Areia } & Q: Quartzito & & DE: Decli & ade \\
\hline \multicolumn{4}{|c|}{ D(S): Distribuída de Silte } & M: Milonito & & - classe $n$ & encontrada na \\
\hline \multicolumn{4}{|c|}{ D(S/A): Distribuída de Silte e Argila } & $\mathrm{X} / \mathrm{Q}:$ Xisto e & Quartzito & \multirow{2}{*}{\multicolumn{2}{|c|}{ área }} \\
\hline $\mathrm{D}(\mathrm{A} / \mathrm{S} / \mathrm{Ar}): \mathrm{Di}$ & buída de & , Silt & & & & & \\
\hline
\end{tabular}


A UG 7 é única unidade que não apresenta qualquer potencial a produção agrícola, isso é devido ao tamanho de sua área, pois é considerada a menor unidade geoambiental do município de Delfinópolis.

A UG 7 também é a única unidade que apresenta toda a sua área classificada com baixa suscetibilidade a inundação, desse modo $89,35 \%$ da sua área apresenta médio potencial ao escoamento superficial. A baixa capacidade de infiltração desta área é condicionada pelo material constituinte, visto que 93,69\% da unidade é composta por silte. Esta partícula de solo por ter textura fina favorece o processo de escoamento o que dificulta a infiltração da água no solo, podendo causar inundação.

Os percentuais de área dos atributos interpretativos analisados para a UG 7 se encontra na Tabela 44.

Tabela 44 - Percentual de área dos produtos interpretativos do meio físico analisados na UG 7.

\begin{tabular}{|c|c|c|c|c|}
\hline Atributos & \multicolumn{4}{|c|}{ Classes (\%) } \\
\hline \multirow{2}{*}{ PPR } & Baixa & Média & Alta & Áreas Inaptas \\
\hline & - & - & - & 100,00 \\
\hline \multirow{2}{*}{ SE } & Baixa & Média & Alta & \\
\hline & 48,70 & 50,80 & 0,50 & \\
\hline \multirow{2}{*}{ SI } & Baixa & Média & Alta & \\
\hline & 100,00 & - & - & \\
\hline \multirow{2}{*}{ PES } & Baixa & Média & Alta & \\
\hline & 0,41 & 89,35 & 10,24 & \\
\hline \multirow{2}{*}{$\mathrm{CI}$} & Baixa & Média a Alta & & \\
\hline & 93,69 & 6,31 & & \\
\hline \multicolumn{5}{|l|}{ Legenda } \\
\hline \multirow{3}{*}{\multicolumn{2}{|c|}{$\begin{array}{l}\text { PPR: Potencial à produção rural } \\
\text { AA: Aptidão agrícola } \\
\text { SE: Suscetibilidade à erosão }\end{array}$}} & & \multirow{3}{*}{\multicolumn{2}{|c|}{$\begin{array}{l}\text { SI: Suscetibilidade à inundação } \\
\text { ES: Potencial ao escoamento superficial } \\
\text { CI: Capacidade de infiltração }\end{array}$}} \\
\hline & & & & \\
\hline & & & & \\
\hline
\end{tabular}

\section{Unidade Geoambiental 8}

É considerada a maior unidade com 560,93 $\mathrm{km}^{2}$, o que compreende $45 \%$ da área total do município. A textura dos solos presentes na unidade apresenta maior fração granulométrica de areia, correspondendo um pouco mais de 60\% (Tabela 45). Esta classe de material inconsolidado se encontra em regiões de serra em que as declividades variam de médias a altas, tendo o quartzito como substrato rochoso dominante. 
O sistema aquífero predominante é o quartzítico, que de acordo com IBAMA (2005), corresponde a aquíferos fraturados, visto que o condicionamento dos fluxos subterrâneos é conduzido pela presença da porosidade secundária, que é evidenciada pelas próprias descontinuidades do meio rochoso, consolidadas pelos planos de fraturas e fissuras.

Tabela 45 - Percentual de área dos atributos do meio físico analisados na UG 8.

\begin{tabular}{|c|c|c|c|c|c|c|c|}
\hline Atributos & \multicolumn{7}{|c|}{ Classes $(\%)$} \\
\hline \multirow{2}{*}{ MI } & Ar & $\mathbf{S}$ & S e R & $\mathbf{D}(\mathbf{A r})$ & $\mathbf{D}(\mathbf{S})$ & $\mathbf{D}(\mathbf{S} / \mathbf{A})$ & $\mathbf{D}(\mathbf{A} / \mathbf{S} / \mathbf{A r})$ \\
\hline & 61,10 & 24,87 & 5,37 & 4,76 & 1,23 & 2,20 & 0,47 \\
\hline \multirow{2}{*}{ SR } & $\mathbf{C Q}$ & $\mathbf{G}$ & $\mathbf{X}$ & $\mathbf{Q}$ & $\mathbf{M}$ & $\mathbf{X} / \mathbf{Q}$ & \\
\hline & 1,00 & 5,75 & 15,50 & 58,22 & 8,70 & 10,83 & \\
\hline \multirow{2}{*}{ SA } & CD & & & \multicolumn{2}{|c|}{ Qt } & \multicolumn{2}{|l|}{$\mathbf{X i}$} \\
\hline & 1,00 & & & \multicolumn{2}{|c|}{66,90} & \multicolumn{2}{|l|}{26,30} \\
\hline \multirow{2}{*}{$\mathrm{DE}$} & $<10 \%$ & & & \multicolumn{4}{|l|}{$>30 \%$} \\
\hline & 28,09 & \multicolumn{2}{|c|}{41,78} & \multicolumn{4}{|l|}{30,13} \\
\hline \multicolumn{6}{|l|}{ Legenda } & \multicolumn{2}{|c|}{ SA: Sistemas Aquíferos } \\
\hline \multicolumn{3}{|c|}{ MI: Materiais Inconsolidados (textura) } & $\mathrm{CC}$ & & \multirow[t]{2}{*}{ oberturas } & \multicolumn{2}{|c|}{ CD: Cobertura Detrítica } \\
\hline \multicolumn{3}{|l|}{ Ar: Areia } & \multicolumn{2}{|c|}{ Quaternárias } & & \multicolumn{2}{|c|}{ GG: Gnáissico-granítico } \\
\hline \multicolumn{3}{|l|}{ S: Silte } & \multicolumn{2}{|c|}{ G: Gnaisse } & & \multicolumn{2}{|c|}{ Qt: Quartizítico } \\
\hline \multicolumn{3}{|c|}{ S e R: Silte e Rocha } & \multicolumn{2}{|c|}{$\mathrm{X}$ : Xisto } & & \multicolumn{2}{|l|}{ Xi: Xistoso } \\
\hline \multicolumn{3}{|c|}{$\mathrm{D}(\mathrm{Ar})$ : Distribuída de Areia } & \multicolumn{2}{|c|}{ Q: Quartzito } & & \multicolumn{2}{|c|}{ DE: Declividade } \\
\hline \multicolumn{2}{|c|}{ D(S): Distribuída de Silte } & & \multirow{2}{*}{\multicolumn{2}{|c|}{ M: Milonito }} & & \multirow{2}{*}{\multicolumn{2}{|c|}{$\begin{array}{l}\text { - classe não encontrada na } \\
\text { área }\end{array}$}} \\
\hline \multirow{2}{*}{\multicolumn{4}{|c|}{ D(A/S/Ar): Distribuída de Argila, Silte e Areia }} & & & & \\
\hline & & & & & & & \\
\hline
\end{tabular}

A UG 8 apresenta $49,44 \mathrm{~km}^{2}(8,82 \%)$ da sua área com alta potencialidade a produção rural, principalmente na região noroeste da unidade (Tabela 46).

A maior parte da unidade apresenta baixa suscetibilidade ao surgimento de processos erosivos, as áreas que apresentam alguma sensibilidade ao aparecimento de feições no solo são as porções em que o material predominante apresenta textura mais grossa.

Quanto às áreas que apresentam alguma suscetibilidade à inundação dentro da UG8, estas estão concentradas na porção sul da unidade, próximas a margem do reservatório de Peixoto, onde as declividades são mais baixas.

A região norte da unidade apresenta alta potencialidade ao escoamento superficial, visto que este potencial não é influenciado pelo tipo de solo da unidade, mas sim pela declividade da área que é considerada bastante elevada. No entanto, considerando a carta de capacidade de infiltração a unidade se destaca na classe média a alta, correspondendo uma 
área de $378,57 \mathrm{~km}^{2}$ composta por quartzito, vale ressaltar que este documento cartográfico não utilizou o atributo de declividade na sua elaboração como a carta de potencial ao escoamento superficial.

Tabela 46 - Percentual de área dos produtos interpretativos do meio físico analisados na UG 8.

\begin{tabular}{|c|c|c|c|c|}
\hline Atributos & \multicolumn{4}{|c|}{ Classes (\%) } \\
\hline \multirow{2}{*}{ PPR } & Baixa & Média & Alta & Áreas Inaptas \\
\hline & 0,03 & 6,20 & 8,82 & 84,95 \\
\hline \multirow{2}{*}{ SE } & Baixa & Média & Alta & \\
\hline & 53,29 & 46,60 & 0,11 & \\
\hline \multirow{2}{*}{ SI } & Baixa & Média & Alta & \\
\hline & 4,30 & 64,80 & 30,90 & \\
\hline \multirow{2}{*}{ PES } & Baixa & Média & Alta & \\
\hline & 18,03 & 37,02 & 44,95 & \\
\hline \multirow{2}{*}{ CI } & Baixa & 'Média a Alta & & \\
\hline & 32,44 & 67,56 & & \\
\hline \multicolumn{5}{|l|}{ Legenda } \\
\hline \multirow{2}{*}{\multicolumn{2}{|c|}{$\begin{array}{l}\text { PPR: Potencial à produção rural } \\
\text { AA: Aptidão agrícola } \\
\text { SF. }\end{array}$}} & & \multirow{3}{*}{\multicolumn{2}{|c|}{$\begin{array}{l}\text { SI: Suscetibilidade à inundação } \\
\text { ES: Potencial ao escoamento superficial } \\
\text { CI: Capacidade de infiltração }\end{array}$}} \\
\hline & & & & \\
\hline SE: Suscetibili & & & & \\
\hline
\end{tabular}

\section{Unidade Geoambiental 9}

A UG 9 abrange aproximadamente 219,40 km², o que corresponde a 17,60\% da área total de estudo. $\mathrm{O}$ material inconsolidado de maior ocorrência na unidade é areia, com o predomínio de $204,50 \mathrm{~km}^{2}$. Este material se localiza em áreas que a declividade é considerada baixa $(<10 \%)$. O substrato rochoso da UG 9 é composto por sua maioria por duas litologias, sendo a primeira os xistos com intercalações de quartzito e a segunda por gnaisse, ambas provenientes das formações geológicas do Grupo Araxá.

Com base nas rochas presentes na área, os sistemas aquíferos que abastecem a unidade são respectivamente o xistoso e gnáissico-granítico (Tabela 47).

Com relação aos documentos interpretativos, a UG 9 apresenta um potencial moderado quanto à produção rural, compreendendo uma área de $146,71 \mathrm{~km}^{2}$, o que corresponde a $66,87 \%$ da área total da unidade. As áreas que compreendem este potencial estão distribuídas em toda a extensão da unidade. 
Tabela 47 - Percentual de área dos atributos do meio físico analisados na UG 9.

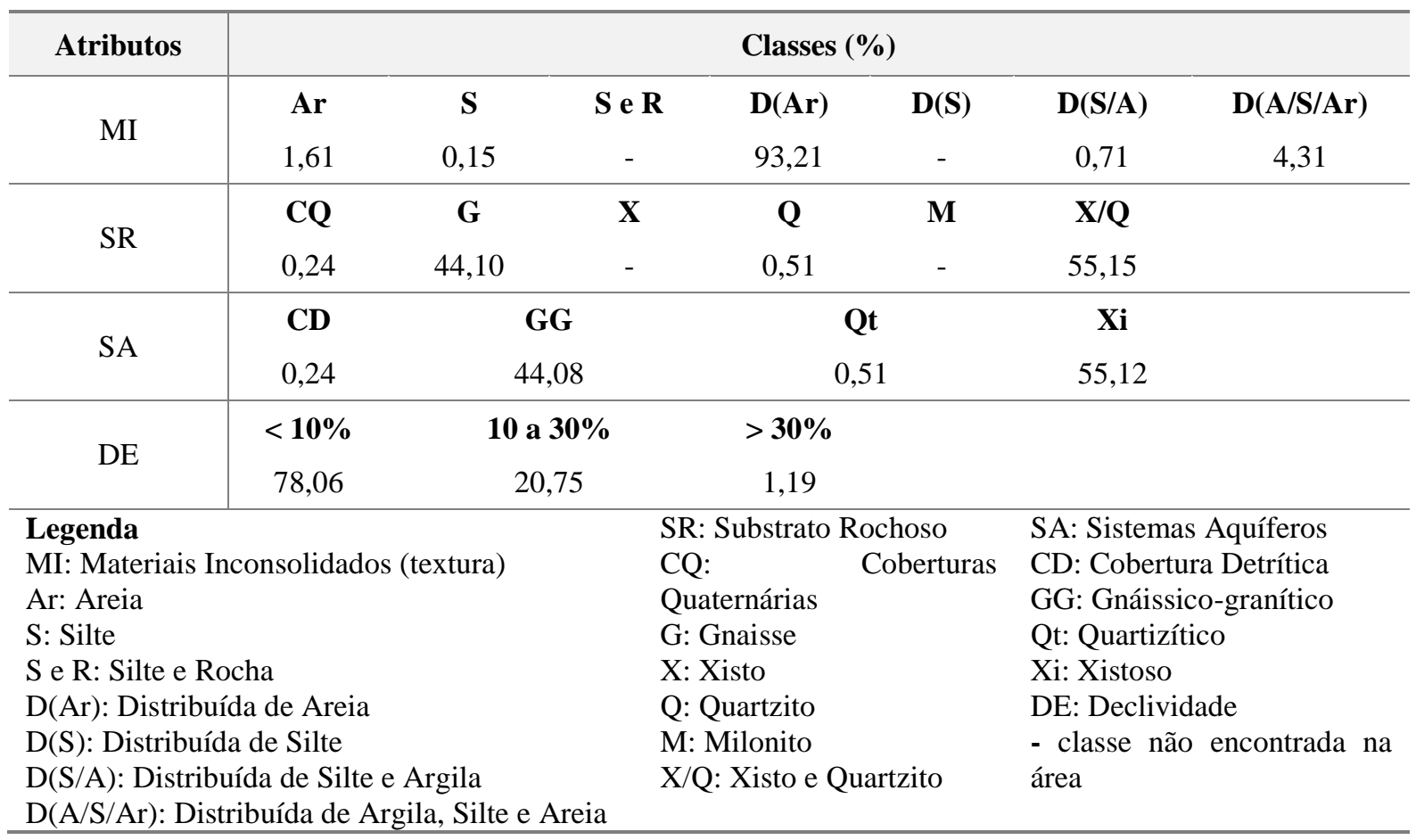

A suscetibilidade da unidade quanto ao surgimento de erosão é considerada média, devido o substrato rochoso e o material inconsolidado que compõe toda a sua área. Sendo que, $55,15 \%$ da área são compostas por xisto e quartzito e 93,21\% da unidade apresenta solo com textura muito arenosa.

Por este motivo também a UG9 é pouco susceptível a processos de inundação, consequentemente o potencial ao escoamento superficial é considerado baixo, dessa forma 99, 10\% da área desta unidade apresenta alta capacidade de infiltração (Tabela 48).

Tabela 48 - Percentual de área dos produtos interpretativos do meio físico analisados na UG 9.

\begin{tabular}{c|cccc}
\hline Atributos & \multicolumn{4}{|c}{ Classes (\%) } \\
\hline \multirow{2}{*}{ PPR } & Baixa & Média & Alta & Áreas Inaptas \\
& - & 66,87 & 1,10 & 32,03 \\
\hline \multirow{2}{*}{ SE } & Baixa & Média & Alta & \\
& 3,12 & 96,17 & 0,71 \\
SI & Baixa & Média & Alta \\
& 74,35 & 25,48 & 0,17 \\
\hline \multirow{2}{*}{ PES } & Baixa & Média & Alta \\
& 93,45 & 6,26 & 0,29 \\
\hline \multirow{2}{*}{ CI } & Baixa & Média a Alta & \\
\hline
\end{tabular}

Legenda

PPR: Potencial à produção rural

AA: Aptidão agrícola

SE: Suscetibilidade à erosão
SI: Suscetibilidade à inundação

ES: Potencial ao escoamento superficial CI: Capacidade de infiltração 


\subsection{Confrontação das unidades geoambientais com as zonas de manejo do PNSC}

Conforme mencionado no item 4.2.5, às áreas das zonas de manejo do Parque Nacional da Serra da Canastra (PNSC) foram quantificadas considerando os limites das nove unidades geoambientais. Vale ressaltar que as três zonas da unidade de conservação presentes na área em estudo não contemplam totalmente o município, sendo que 14,89\% compreendem as áreas ao entorno do perímetro urbano da cidade de Delfinópolis e do distrito da Babilônia, além de uma parte da região oeste do município.

Com base nos valores obtidos, a Zona Intangível (ZI) abrange uma área de $66,33 \mathrm{~km}^{2}$ (4,81\% da área total do município), sendo definida pelo IBAMA (2005) como uma área restritiva ao uso humano devido as suas características naturais. Esta área tem como finalidade à proteção integral de ecossistemas, dos recursos genéticos e ao monitoramento ambiental, tendo como objetivo básico de manejo a preservação, de forma a garantir a evolução natural.

A ZI é ocupada por três unidades geoambientais (UG 4; UG 6; UG 8), sendo que a unidade geoambiental que apresenta em maior percentual é a UG 8 (96,52\%). A UG 8 é uma das unidades que apresentam melhor preservação dentro do município, respeitando dessa forma os critérios estabelecidos pelo plano de manejo da unidade de conservação.

A Zona de Ocupação Temporária (ZOT) engloba uma área de 490,13 km² (35,56\% da área total), esta área apresenta grande diversidade quanto aos aspectos físicos e geológicos. Das nove unidades delimitadas no município esta zona compreende sete unidades geoambientais, a UG 8 é a unidade que se apresenta em maior área, em seguida a unidade UG 4 se destaca com $22,71 \%$. Vale ressaltar que esta zona é provisória, portanto, a partir da sua regularização as práticas humanas poderão permanecer, caso contrário, as atividades deverão ser interrompidas.

Com área igual a 616,71 km² (44,74\% da área total), a Zona de Amortecimento (ZAm) contempla oito unidades geoambientais, sendo as que se destacam em área são respectivamente são a UG 4, UG 9 e UG 8. Nesta área se concentram as atividades econômicas do município de Delfinópolis, como o plantio de culturas anuais ou permanentes, atividades minerárias com extração de cascalho e areia, além do turismo, com a presença de atrativos turísticos e pousadas. 
Todas as atividades desenvolvidas na ZAm deverão estar licenciadas pelo órgão ambiental competente, pois esta zona contempla todo o entorno da unidade de conservação, onde as intervenções antrópicas estão sob o domínio de normas e restrições específicas, com a intenção de minimizar os danos sobre a área protegida.

A Tabela 49 apresenta a área em $\mathrm{km}^{2}$ e \% das zonas de manejo do PNSC presentes em cada unidade geoambiental.

Tabela 49 - Área $\left(\mathrm{km}^{2} \mathrm{e} \%\right)$ das zonas de manejo do PNSC situadas nas unidades geoambientais.

\begin{tabular}{c|c|c|c|c|c|c|c|c|c|c}
\hline \multirow{2}{*}{$\begin{array}{c}\text { Zonas de } \\
\text { Manejo }\end{array}$} & \multicolumn{7}{c}{ Unidades Geoambientais } \\
\cline { 2 - 11 } & UG 1 & UG 2 & UG 3 & UG 4 & UG 5 & UG 6 & UG 7 & UG 8 & UG 9 \\
\hline \multirow{2}{*}{ ZI } & $\mathrm{Km}^{2}$ & - & - & - & 2,30 & - & 0,007 & - & 64,02 & - \\
\cline { 2 - 12 } & $\%$ & - & - & - & 3,47 & - & 0,01 & - & 96,52 & - \\
\hline \multirow{2}{*}{ ZOT } & $\mathrm{Km}^{2}$ & - & 0,21 & - & 111,34 & 34,72 & 2,13 & 0,44 & 340,26 & 1,24 \\
\cline { 2 - 12 } & $\%$ & - & 0,04 & - & 22,71 & 7,08 & 0,43 & 0,10 & 69,39 & 0,25 \\
\hline \multirow{2}{*}{ ZAm } & $\mathrm{Km}$ & 4,34 & 2,78 & 4,31 & 215,06 & 35,17 & 12,24 & - & 133,90 & 208,78 \\
\cline { 2 - 12 } & $\%$ & 0,70 & 0,45 & 0,70 & 34,88 & 5,70 & 1,99 & - & 21,72 & 33,86 \\
\hline
\end{tabular}

Da mesma forma que foi contabilizada as áreas das zonas de manejo para cada uma das unidades geoambientais, também foi realizada a tabulação cruzada das áreas de cada uma das unidades considerando as delimitações das três zonas de manejo do PNSC. A Tabela 50 mostra os valores em $\mathrm{km}^{2}$ e em \% das áreas.

Dentre as unidades geoambientais, apenas três destas estão inseridas totalmente em uma única zona de manejo, sendo a UG 1, UG 3 e a UG 7, sendo as duas primeiras situadas dentro da ZAm e a última situada na ZOT. A UG 1 e UG 3 se encontram em uma situação com maior alteração do meio natural comparada com a unidade UG 7, pelo motivo de suas áreas estarem inseridas na ZAm, a qual permite as práticas humanas desde que estas disponham de licença ambiental.

As unidades geoambientais UG 2, UG 5 e UG 9 apresentam suas áreas distribuídas na ZOT e ZAm. As três unidades geoambientais apresentam um maior percentual de suas áreas inseridas na ZAm, com $92,86 \%, 50,32 \%$ e $99,41 \%$, respectivamente. 
Tabela 50 - Área $\left(\mathrm{km}^{2} \mathrm{e} \%\right)$ das unidades geoambientais situadas nas zonas de manejo do PNSC.

\begin{tabular}{c|c|c|c|c|c|c|c}
\hline \multirow{2}{*}{$\begin{array}{c}\text { Unidades } \\
\text { Geoambientais } \\
\text { (UG) }\end{array}$} & $\begin{array}{c}\text { Área das } \\
\text { UGs } \\
\text { inseridas } \\
\text { nas } \\
\text { zonas } \\
\left(\mathbf{k m}^{2}\right)\end{array}$ & \multicolumn{2}{|c|}{$\begin{array}{c}\text { Zona Intangível } \\
(\mathbf{Z I})\end{array}$} & \multicolumn{2}{|c|}{$\begin{array}{c}\text { Zona de Ocupação } \\
\text { Temporária } \\
\text { (ZOT) }\end{array}$} & \multicolumn{2}{c}{$\begin{array}{c}\text { Zona de } \\
\text { Amortecimento } \\
\text { (ZAm) }\end{array}$} \\
\cline { 5 - 9 } UG 1 & 4,34 & - & - & - & - & 4,34 & 100 \\
\hline UG 2 & 2,99 & - & - & 0,21 & 7,14 & 2,78 & 92,86 \\
\hline UG 3 & 4,31 & - & - & - & - & 4,31 & 100 \\
\hline UG 4 & 328,70 & 2,30 & 0,70 & 111,34 & 33,87 & 215,06 & 65,43 \\
\hline UG 5 & 69,89 & - & - & 34,72 & 49,68 & 35,17 & 50,32 \\
\hline UG 6 & 14,38 & 0,01 & 0,05 & 2,13 & 14,80 & 12,24 & 85,15 \\
\hline UG 7 & 0,44 & - & - & 0,44 & 100,00 & - & - \\
\hline UG 8 & 538,18 & 64,02 & 11,90 & 340,26 & 63,22 & 133,90 & 24,88 \\
\hline UG 9 & 210,02 & - & - & 1,24 & 0,59 & 208,78 & 99,41 \\
\hline
\end{tabular}

As áreas das três últimas unidades geoambientais (UG 4, UG 6 e UG 8) estão divididas nas três zonas de manejo. Sendo que as unidades UG 4 e UG 6 possuem maior área dentro da ZAm, enquanto que a UG 8 se concentra na ZOT, compreendendo uma área de 340, 26 km² (63,22\%). A Figura 38 apresenta a espacialização das zonas de manejo do PNSC bem como as nove unidades geoambientais. 

Figura 38 - Mapa das unidades geoambientais do município de Delfinópolis e as zonas de manejo do PNSC.

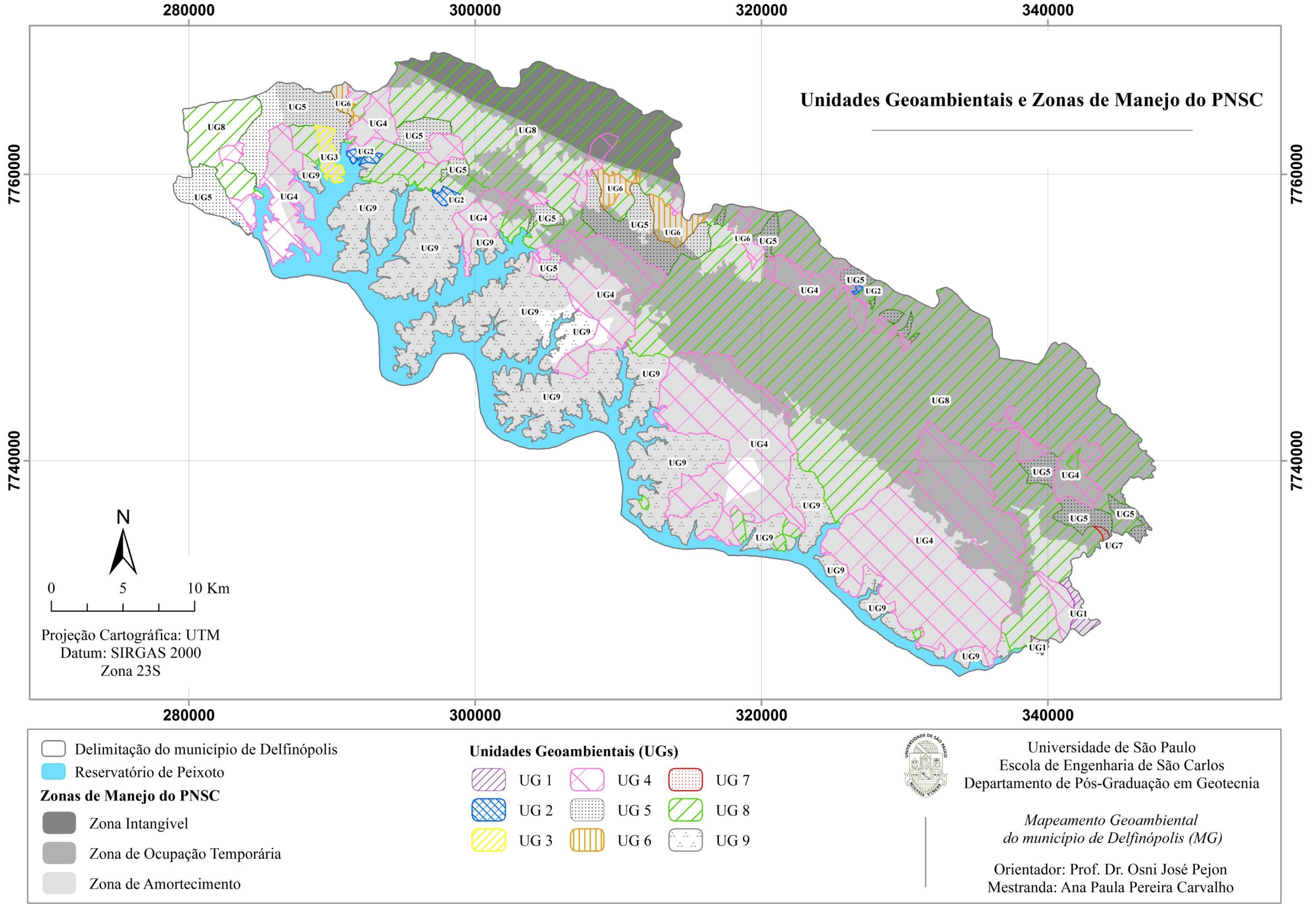





\subsubsection{Considerações sobre as zonas de manejo e o mapeamento geoambiental do município}

Neste tópico estão apresentados alguns pontos relevantes após o mapeamento geoambiental do município frente às zonas de manejo do PNSC estabelecidas pelo IBAMA (2005). Com base na confrontação das zonas de manejo com as nove unidades geoambientais, pode-se verificar a compatibilidade de algumas unidades com a finalidade da criação das três zonas que contemplam a área de estudo.

Neste contexto, pode-se citar as unidades UG 1 e UG 3, como áreas que se encontram totalmente inseridas na ZAm, sendo esta a principal zona responsável pelo PIB do município, devido ser uma área em que permite o uso e ocupação do solo para fins econômicos e não somente para pesquisa científica e recreação. Desse modo, com base no mapeamento geoambiental realizado neste trabalho verifica-se a compatibilidade do uso e manejo destas duas delimitações (unidades e zonas).

Após este estudo geoambiental, observa-se também que a unidade UG 9 apresenta a mesma função com relação a ZAm, mesmo não estando totalmente inserida no seu limite. Nesta perspectiva estas três unidades (UG 1, UG 3 e UG 9) devem continuar considerando as normas estipuladas pelo plano de manejo do PNSC visando o desenvolvimento do município de maneira racional.

Outra observação importante considerada após o mapeamento foi à semelhança das características físicas do ponto de vista geológico-geotécnico das ZI e ZOT. É possível observar neste trabalho que estas duas zonas apresentam a maior parte de suas áreas espacializadas na unidade UG 8. Devido a esta condição, pode-se considerar que as duas zonas deveriam apresentar uma mesma funcionalidade. No entanto estudos mais detalhados do ponto de vista ambiental e social deveriam ser realizados, de maneira a avaliar a transformação destas áreas em uma única compartimentação dentro do município de Delfinópolis, talvez com maior nível de proteção.

As áreas das unidades (UG 2, UG 4, UG 5, UG 6 e UG 7) são as que menos condizem com os limites das zonas definidas no zoneamento do PNSC. Porém, estas unidades podem servir para orientar na atualização deste zoneamento, bem como na criação de uma nova zona de manejo na região norte do município onde se encontra parte das unidades UG 2, UG 4 e UG 6, permitindo nestas áreas a utilização do solo pela população residente. 


\subsection{Unidades geoambientais e áreas ambientais com restrição legal}

As áreas ambientais com restrição legal no município de Delfinópolis foram mapeadas de acordo com o que determina o Novo Código Florestal no 12.651/2012, a Resolução CONAMA no 302/2002 e a Lei Federal nº 9.985/2000.

Conforme citado no item 4.2.6, para o mapeamento destas áreas foram consideradas as seguintes classes: APPs dos canais de drenagem de $1^{\mathrm{a}}, 2^{\mathrm{a}}, 3^{\mathrm{a}}$ e $4^{\mathrm{a}}$ ordem; APPs dos canais de drenagem de $5^{\mathrm{a}}$ e $6^{\mathrm{a}}$ ordem; APP do reservatório de Peixoto; APPs dos topos de morro com inclinação média maior que $25^{\circ}$; e as zonas de manejo do Parque Nacional da Serra da Canastra.

A Tabela 51 apresenta a quantificação de áreas de preservação permanente $\left(\mathrm{km}^{2} \mathrm{e} \%\right)$ que pela legislação deveriam compor as unidades geoambientais.

Tabela 51 - Áreas de preservação permanente que deveriam existir nas unidades geoambientais conforme a legislação.

\begin{tabular}{|c|c|c|c|c|c|c|c|c|c|c|}
\hline \multirow{3}{*}{$\begin{array}{c}\text { Unidades } \\
\text { Geoambientais } \\
\text { (UGs) }\end{array}$} & \multicolumn{10}{|c|}{ Áreas de Preservação Permanente } \\
\hline & \multicolumn{2}{|c|}{$\begin{array}{c}\text { APP dos } \\
\text { cursos d'água } \\
1^{\mathrm{a}}, 2^{\mathrm{a}}, 3^{\mathrm{a}} \text { e } 4^{\mathrm{a}} \\
\text { ordem }\end{array}$} & \multicolumn{2}{|c|}{$\begin{array}{c}\text { APP dos } \\
\text { cursos } \\
\text { d'água } 5^{\mathbf{a}} \text { e } \\
6^{\mathbf{a}} \text { ordem }\end{array}$} & \multicolumn{2}{|c|}{$\begin{array}{c}\text { APP do } \\
\text { reservatório } \\
\text { de Peixoto }\end{array}$} & \multicolumn{2}{|c|}{$\begin{array}{c}\text { APP dos } \\
\text { topos de } \\
\text { morro }\end{array}$} & \multicolumn{2}{|c|}{$\begin{array}{c}\text { Total } \\
\text { de APPs }\end{array}$} \\
\hline & $\mathbf{k m}^{2}$ & $\%$ & $\mathbf{k m}^{2}$ & $\%$ & $\mathbf{k m}^{2}$ & $\%$ & $\mathbf{k m}^{2}$ & $\%$ & $\mathbf{k m}^{2}$ & $\%$ \\
\hline UG 1 & 0,20 & 4,35 & 0,50 & 11,48 & 0,01 & 0,34 & 0,25 & 5,65 & 0,95 & 21,82 \\
\hline UG 2 & 0,41 & 13,55 & 0,04 & 1,23 & 0,30 & 9,86 & 0,05 & 1,70 & 0,80 & 26,34 \\
\hline UG 3 & 0,31 & 7,19 & - & - & 0,71 & 16,54 & 0,43 & 9,87 & 1,45 & 33,60 \\
\hline UG 4 & 36,67 & 10,51 & 2,28 & 0,65 & 7,13 & 2,04 & 42,47 & 12,17 & 88,55 & 25,37 \\
\hline UG 5 & 9,88 & 10,90 & 1,97 & 2,17 & 0,56 & 0,61 & 13,22 & 14,58 & 25,63 & 28,26 \\
\hline UG 6 & 1,16 & 8,07 & 0,96 & 6,65 & 0,01 & 0,04 & 0,85 & 5,92 & 2,98 & 20,68 \\
\hline UG 7 & 0,04 & 8,59 & 0,03 & 6,54 & - & - & - & - & 0,07 & 15,13 \\
\hline UG 8 & 128,52 & 22,91 & 3,61 & 0,64 & 2,08 & 0,37 & 118,86 & 21,19 & 253,07 & 45,11 \\
\hline UG 9 & 8,22 & 3,75 & - & - & 33,27 & 15,16 & 0,79 & 0,36 & 42,28 & 19,27 \\
\hline
\end{tabular}

Após o mapeamento das APPs considerando os aspectos legais, a unidade UG 8 é a que deveria possuir o maior percentual de área de preservação permanente, correspondendo a $45,11 \%\left(253,07 \mathrm{~km}^{2}\right)$, sendo que $22,91 \%$ deste contingente deveriam ser ocupados pelas APPs 
dos cursos d'água até $4^{\mathrm{a}}$ ordem. A UG 8 também se destaca com relação as APPs dos topos de morro, devido ser uma região de serras que apresenta altitude que varia de $665 \mathrm{~m}$ a $1.445 \mathrm{~m}$, onde se situa parte da Serra da Guarita e da Serra do Cemitério.

Já as unidades UG 7 e UG 9 são as que menos necessitam de APPs, correspondendo respectivamente a $15,13 \%$ e $19,27 \%$. Um dos motivos que levam estas unidades a apresentarem menor percentual de áreas preservadas, quando comparadas com as demais é a baixa disponibilidade hídrica em suas extensões. Outro fator que colabora com tal condição é a declividade, pois estas unidades estão situadas em regiões em que a inclinação da superfície é moderada, não sendo necessárias as APPs nos topos de morro que não atingem inclinação superior a $25^{\circ}$.

A UG 3 e UG 9 são as únicas unidades que não apresentam APP de cursos d'água de $5^{\mathrm{a}}$ e $6^{\mathrm{a}}$ ordem, devido não possuírem rios superiores a $4^{\mathrm{a}}$ ordem de ramificação. $\mathrm{O}$ maior percentual deste tipo de APP se encontra na UG 1, pelo motivo da unidade ser margeada por um curso d'água que ultrapassa 10 metros de largura dividindo os limites dos municípios de Delfinópolis e São João Batista do Glória.

As unidades UG 1, UG 2, UG 4, UG 5 e UG 6 apresentam seus percentuais de APPs entre $20,68 \%$ a $28,26 \%$, ou seja, os valores de APPs dentro dos seus limites é considerado baixo, com relação as unidades que possuem maior espaço territorial.

Após o mapeamento das APPs, foi calculado o percentual de área de vegetação natural (mata, campo e capoeira) que compõe os quatro tipos de APPs apresentados neste trabalho (Tabela 52). As áreas ocupadas por estas três classes de vegetação natural foram obtidas a partir da confrontação das áreas de APP com as informações do mapa de uso e ocupação do solo atualizado de Dias (2013).

Tabela 52 - Porcentagens de Mata, Campo e Capoeira presentes nas áreas de preservação permanente em cada unidade geoambiental.

\begin{tabular}{|c|c|c|c|c|c|c|c|c|c|c|c|c|}
\hline \multirow{3}{*}{ UGs } & \multirow{3}{*}{$\begin{array}{l}\text { Total de } \\
\text { APPs } \\
\text { conforme a } \\
\text { legislação } \\
\left(\mathbf{k m}^{2}\right)\end{array}$} & \multicolumn{11}{|c|}{ Áreas de Preservação Permanente nas unidades geoambientais } \\
\hline & & \multirow[t]{2}{*}{$\begin{array}{c}\text { Classes de } \\
\text { Vegetação } \\
\text { Natural }\end{array}$} & \multicolumn{2}{|c|}{$\begin{array}{c}\text { APP dos } \\
\text { cursos } \\
\text { d'água } 1^{\mathrm{a}}, 2^{\mathrm{a}}, \\
3^{\mathrm{a}} \text { e } 4^{\mathrm{a}} \text { ordem }\end{array}$} & \multicolumn{2}{|c|}{$\begin{array}{c}\text { APP dos } \\
\text { cursos } \\
\text { d'água } 5^{\mathrm{a}} \mathrm{e} \\
6^{\mathrm{a}} \text { ordem }\end{array}$} & \multicolumn{2}{|c|}{$\begin{array}{c}\text { APP do } \\
\text { reservatório } \\
\text { de Peixoto }\end{array}$} & \multicolumn{2}{|c|}{$\begin{array}{c}\text { APP dos } \\
\text { topos de } \\
\text { morro }\end{array}$} & \multicolumn{2}{|c|}{$\begin{array}{l}\text { Total de APPs } \\
\text { nas UGs }\end{array}$} \\
\hline & & & $\mathbf{k m}^{2}$ & $\%$ & $\mathbf{k m}^{2}$ & $\%$ & $\mathbf{k m}^{2}$ & $\%$ & $\mathbf{k m}^{2}$ & $\%$ & $\mathbf{k m}^{2}$ & $\%$ \\
\hline \multirow{4}{*}{ UG 1} & \multirow{4}{*}{0,95} & Mata & 0,08 & 8,42 & 0,23 & 24,21 & 0,01 & 1,05 & 0,01 & 1,05 & 0,33 & 34,73 \\
\hline & & Campo & - & - & 0,03 & 3,16 & - & - & - & - & 0,03 & 3,16 \\
\hline & & Capoeira & - & - & - & - & - & - & - & - & - & - \\
\hline & & Total & 0,08 & 8,42 & 0,26 & 27,37 & 0,01 & 1,05 & 0,01 & 1,05 & 0,36 & 37,89 \\
\hline
\end{tabular}


Tabela 52 - Porcentagens de Mata, Campo e Capoeira presentes nas áreas de preservação permanente em cada unidade geoambiental (continuação).

\begin{tabular}{|c|c|c|c|c|c|c|c|c|c|c|c|c|}
\hline \multirow{3}{*}{ UGs } & \multirow{3}{*}{$\begin{array}{c}\text { Total de } \\
\text { APPs } \\
\text { conforme a } \\
\text { legislação } \\
\left(\mathbf{k m}^{2}\right)\end{array}$} & \multicolumn{11}{|c|}{ Áreas de Preservação Permanente nas unidades geoambientais } \\
\hline & & \multirow[t]{2}{*}{$\begin{array}{c}\text { Classes de } \\
\text { Vegetação } \\
\text { Natural }\end{array}$} & \multicolumn{2}{|c|}{$\begin{array}{c}\text { APP dos } \\
\text { cursos } \\
\text { d'água } 1^{\mathbf{a}}, \mathbf{2}^{\mathbf{a}}, \\
\mathbf{3}^{\mathrm{a}} \text { e } \mathbf{4}^{\mathrm{a}} \text { ordem }\end{array}$} & \multicolumn{2}{|c|}{$\begin{array}{c}\text { APP dos } \\
\text { cursos } \\
\text { d'água } 5^{\text {a e }} \\
6^{\text {a } \text { ordem }}\end{array}$} & \multicolumn{2}{|c|}{$\begin{array}{c}\text { APP do } \\
\text { reservatório } \\
\text { de Peixoto }\end{array}$} & \multicolumn{2}{|c|}{$\begin{array}{l}\text { APP dos } \\
\text { topos de } \\
\text { morro }\end{array}$} & \multicolumn{2}{|c|}{$\begin{array}{l}\text { Total de APPs } \\
\text { nas UGs }\end{array}$} \\
\hline & & & $\mathbf{k m}^{2}$ & $\%$ & $\mathbf{k m}^{2}$ & $\%$ & $\mathbf{k m}^{2}$ & $\%$ & $\mathbf{k m}^{2}$ & $\%$ & $\mathbf{k m}^{2}$ & $\%$ \\
\hline \multirow{4}{*}{ UG 2} & \multirow{4}{*}{0,80} & Mata & 0,05 & 6,25 & 0,03 & 3,75 & 0,04 & 5,00 & 0,00 & 0,00 & 0,12 & 15,00 \\
\hline & & Campo & 0,33 & 41,25 & 0,01 & 1,25 & 0,08 & 10,00 & 0,05 & 6,25 & 0,47 & 58,75 \\
\hline & & Capoeira & - & - & - & - & - & - & - & - & - & - \\
\hline & & Total & 0,38 & 47,50 & 0,04 & 5,00 & 0,12 & 15,00 & 0,05 & 6,25 & 0,59 & 73,75 \\
\hline \multirow{4}{*}{ UG 3} & \multirow{4}{*}{1,45} & Mata & 0,07 & 4,82 & - & - & 0,07 & 4,83 & - & - & 0,14 & 9,65 \\
\hline & & Campo & 0,12 & 8,28 & - & - & - & - & 0,41 & 28,27 & 0,53 & 36,55 \\
\hline & & Capoeira & - & - & - & - & - & - & - & - & - & - \\
\hline & & Total & 0,19 & 13,10 & - & - & 0,07 & 4,83 & 0,41 & 28,27 & 0,67 & 46,20 \\
\hline \multirow{4}{*}{ UG 4} & \multirow{4}{*}{88,55} & Mata & 17,72 & 20,01 & 1,12 & 1,26 & 2,26 & 2,55 & 2,40 & 2,71 & 23,50 & 26,53 \\
\hline & & Campo & 10,08 & 11,38 & 0,05 & 0,06 & 0,38 & 0,43 & 36,22 & 40,90 & 46,73 & 52,77 \\
\hline & & Capoeira & 0,10 & 0,11 & 0,01 & 0,01 & 0,06 & 0,07 & 0,01 & 0,01 & 0,18 & 0,20 \\
\hline & & Total & 27,90 & 31,50 & 1,18 & 1,33 & 2,70 & 3,05 & 38,63 & 43,62 & 70,41 & 79,50 \\
\hline \multirow{4}{*}{ UG 5} & \multirow{4}{*}{25,63} & Mata & 4,66 & 18,18 & 0,92 & 3,59 & 0,12 & 0,47 & 0,47 & 1,83 & 6,17 & 24,07 \\
\hline & & Campo & 3,85 & 15,02 & 0,28 & 1,10 & 0,26 & 1,01 & 11,45 & 44,67 & 15,84 & 61,80 \\
\hline & & Capoeira & 0,05 & 0,20 & 0,01 & 0,04 & - & - & 0,03 & 0,12 & 0,09 & 0,36 \\
\hline & & Total & 8,56 & 33,40 & 1,21 & 4,73 & 0,38 & 1,48 & 11,95 & 46,62 & 22,10 & 86,23 \\
\hline \multirow{4}{*}{ UG 6} & \multirow{4}{*}{2,98} & Mata & 0,63 & 21,14 & 0,47 & 15,77 & - & - & 0,05 & 1,68 & 1,15 & 38,59 \\
\hline & & Campo & 0,10 & 3,36 & 0,03 & 1,01 & - & - & 0,75 & 25,17 & 0,88 & 29,54 \\
\hline & & Capoeira & - & - & - & - & - & - & - & - & - & - \\
\hline & & Total & 0,73 & 24,50 & 0,50 & 16,78 & - & - & 0,80 & 26,85 & 2,03 & 68,13 \\
\hline \multirow{4}{*}{ UG 7} & \multirow{4}{*}{0,07} & Mata & 0,02 & 28,57 & 0,01 & 14,28 & - & - & - & - & 0,03 & 42,85 \\
\hline & & Campo & 0,01 & 14,28 & 0,01 & 14,28 & - & - & - & - & 0,02 & 28,56 \\
\hline & & Capoeira & - & - & - & - & - & - & - & - & - & - \\
\hline & & Total & 0,03 & 42,85 & 0,02 & 28,56 & - & - & - & - & 0,05 & 71,41 \\
\hline \multirow{4}{*}{ UG 8} & \multirow{4}{*}{253,07} & Mata & 24,93 & 9,85 & 1,48 & 0,58 & 0,46 & 0,18 & 2,90 & 1,15 & 29,77 & 11,76 \\
\hline & & Campo & 40,12 & 15,85 & 1,11 & 0,44 & 0,52 & 0,20 & 111,17 & 43,93 & 152,92 & 60,42 \\
\hline & & Capoeira & 0,38 & 0,15 & 0,02 & 0,007 & - & - & 0,27 & 0,11 & 0,67 & 0,27 \\
\hline & & Total & 65,43 & 25,85 & 2,61 & 1,03 & 0,98 & 0,38 & 114,34 & 45,19 & 183,36 & 72,45 \\
\hline \multirow{4}{*}{ UG 9} & \multirow{4}{*}{42,28} & Mata & 4,97 & 11,75 & - & - & 5,59 & 13,22 & 0,06 & 0,14 & 10,62 & 25,11 \\
\hline & & Campo & 0,18 & 0,43 & - & - & 0,57 & 1,35 & 0,51 & 1,21 & 1,26 & 2,99 \\
\hline & & Capoeira & 0,01 & 0,02 & - & - & 0,03 & 0,07 & - & - & 0,04 & 0,09 \\
\hline & & Total & 5,16 & 12,20 & - & - & 6,19 & 14,64 & 0,57 & 1,35 & 11,92 & 28,19 \\
\hline
\end{tabular}


A Figura 39 apresenta o gráfico com as porcentagens em área do total de APPs de cada unidade geoambiental ocupadas por vegetação natural.

Figura 39 - Percentual de área das APPs em cada unidade geoambiental ocupada por vegetação natural.

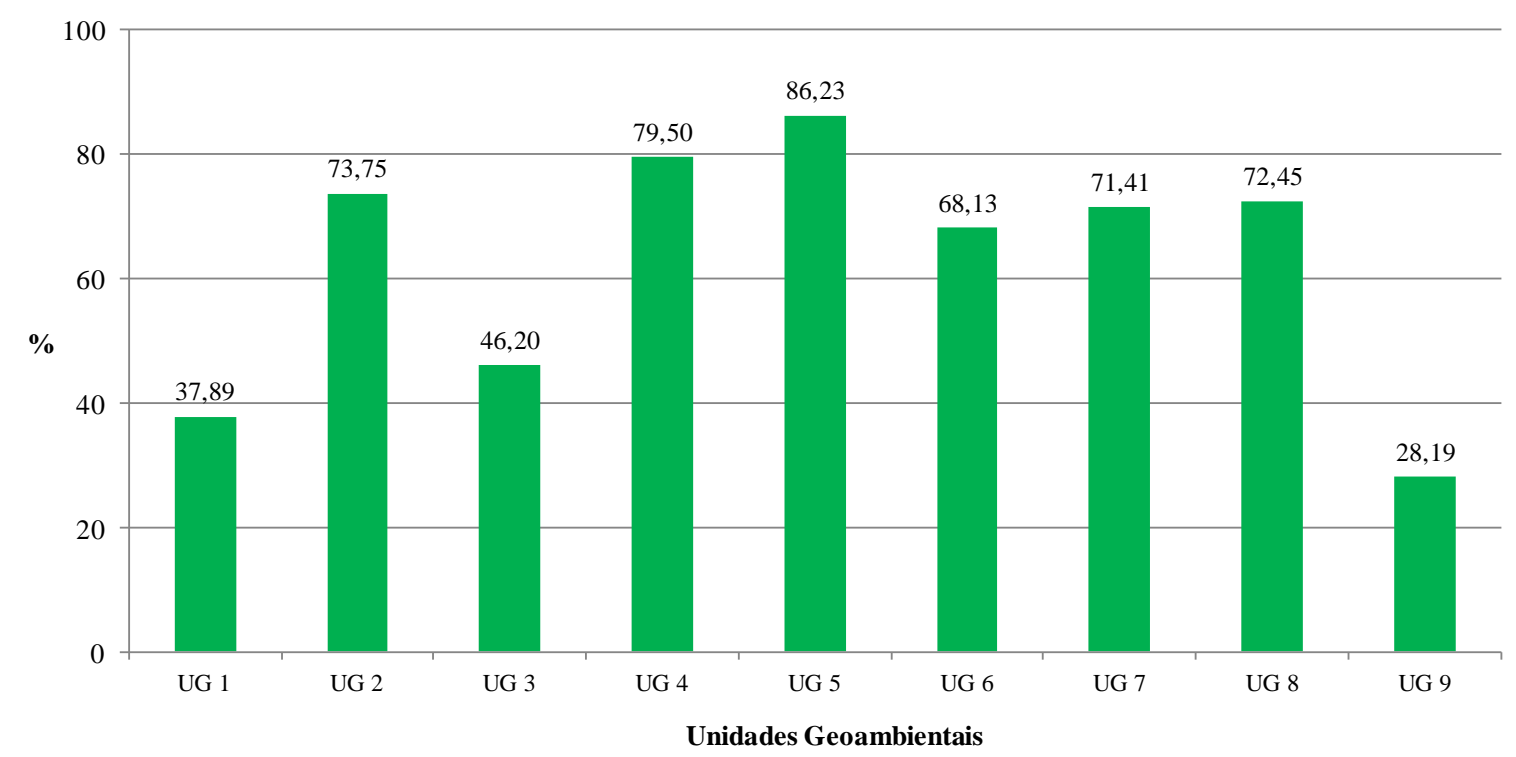

De acordo com o mapeamento das áreas ambientais realizado considerando a legislação vigente, é possível observar que nenhuma unidade geoambiental obedece totalmente os limites das áreas de preservação permanente, sendo assim estas áreas apresentam outros usos, como exemplo, as culturas agrícolas, pastagens e chacreamentos. Dentre as unidades, a UG 5 é a que mais condiz com o que estabelece a legislação, respeitando 86,23\% do total de APPs dentro do seu limite ocupado por vegetação natural. Já a UG 9 apresenta o menor percentual de área composta por vegetação natural, correspondendo apenas 28,19\% do total dos quatro tipos de APPs mapeadas. Um dos principais motivos que leva esta unidade apresentar este percentual é a condição topográfica em que se encontra, ou seja, a unidade apresenta baixas declividades, o que proporciona maior facilidade para a plantação e colheita das culturas, dessa forma a produção agrícola acaba suprimindo os limites das APPs para a realização destas ações.

A Tabela 53 apresenta o déficit de cada uma das unidades geoambientais com relação às APPs que devem ser respeitadas seguindo os aspectos legais. 
Tabela 53 - Déficit de cobertura vegetal (\%) das áreas de preservação permanente nas unidades geoambientais.

\begin{tabular}{c|c|c|c}
\hline $\begin{array}{c}\text { Unidades } \\
\text { Geoambientais }\end{array}$ & $\begin{array}{c}\text { APPs mapeadas } \\
\text { conforme a legislação } \\
\left(\mathbf{k m}^{\mathbf{2}}\right)\end{array}$ & $\begin{array}{c}\text { APPs ocupadas por } \\
\text { vegetação natural } \\
\left(\mathbf{k m}^{\mathbf{2}}\right)\end{array}$ & $\begin{array}{c}\text { Déficit } \\
\text { das APPs } \\
(\boldsymbol{\%})\end{array}$ \\
\hline UG 1 & 0,95 & 0,36 & 62,11 \\
\hline UG 2 & 0,80 & 0,59 & 26,25 \\
\hline UG 3 & 1,45 & 0,67 & 53,80 \\
\hline UG 4 & 88,55 & 70,41 & 20,50 \\
\hline UG 5 & 25,63 & 22,10 & 13,77 \\
\hline UG 6 & 2,98 & 2,03 & 31,87 \\
\hline UG 7 & 0,07 & 0,05 & 28,59 \\
\hline UG 8 & 253,07 & 183,36 & 27,55 \\
\hline UG 9 & 42,28 & 11,92 & 71,81 \\
\hline
\end{tabular}

As unidades geoambientais que menos obedecem aos limites de vegetação natural nas APPs são respectivamente: UG 9 (71,81\%); UG 1 (62,11\%); UG 3 (53,80\%). Estas três unidades apresentam mais da metade das suas APPs ocupadas por outro tipo de uso, como exemplo: as culturas anuais e permanentes; as pastagens; e os chacreamentos. Como mencionado anteriormente, a UG 5 se encontra mais próxima da legalidade imposta pelo Novo Código Florestal sobre as APPs, pois apenas 13,77\% destas áreas não apresentam vegetação natural.

A Figura 40 apresenta o mapa de áreas de proteção que deveriam existir no município de Delfinópolis de acordo com a legislação ambiental vigente. A Tabela 54 apresenta o total $\left(\mathrm{km}^{2}\right.$ e \%) destas áreas no município. Observa-se que o município apresenta quase um terço de sua área que deveria ser ocupada pelas APPs, que representa quase o mesmo espaço físico de uma das zonas de manejo do PNSC, mais especificamente a ZOT.

Tabela 54 - Total $\left(\mathrm{km}^{2}\right.$ e \%) das áreas de proteção que deveriam existir no município de Delfinópolis.

\begin{tabular}{c|c|c}
\hline \multicolumn{3}{c}{ APPs que deveriam existir em Delfinópolis } \\
\hline Tipos & $\mathbf{K m}^{\mathbf{2}}$ & $\mathbf{\%}$ \\
\hline APPs cursos d'água de $1^{\mathrm{a}}, 2^{\mathrm{a}}, 3^{\mathrm{a}}$ e $4^{\mathrm{a}}$ ordem & 185,32 & 13,44 \\
\hline APPs cursos d'água de $5^{\mathrm{a}}$ e $6^{\mathrm{a}}$ ordem & 9,37 & 0,68 \\
\hline APP do Reservatório de Peixoto & 44,07 & 3,20 \\
\hline APP dos topos de morro & 176,81 & 12,83 \\
\hline Total & 415,58 & 30,15 \\
\hline
\end{tabular}


Figura 40 - Mapa de área de proteç̃o no município de Delfinópolis de acordo com a legislação ambiental.

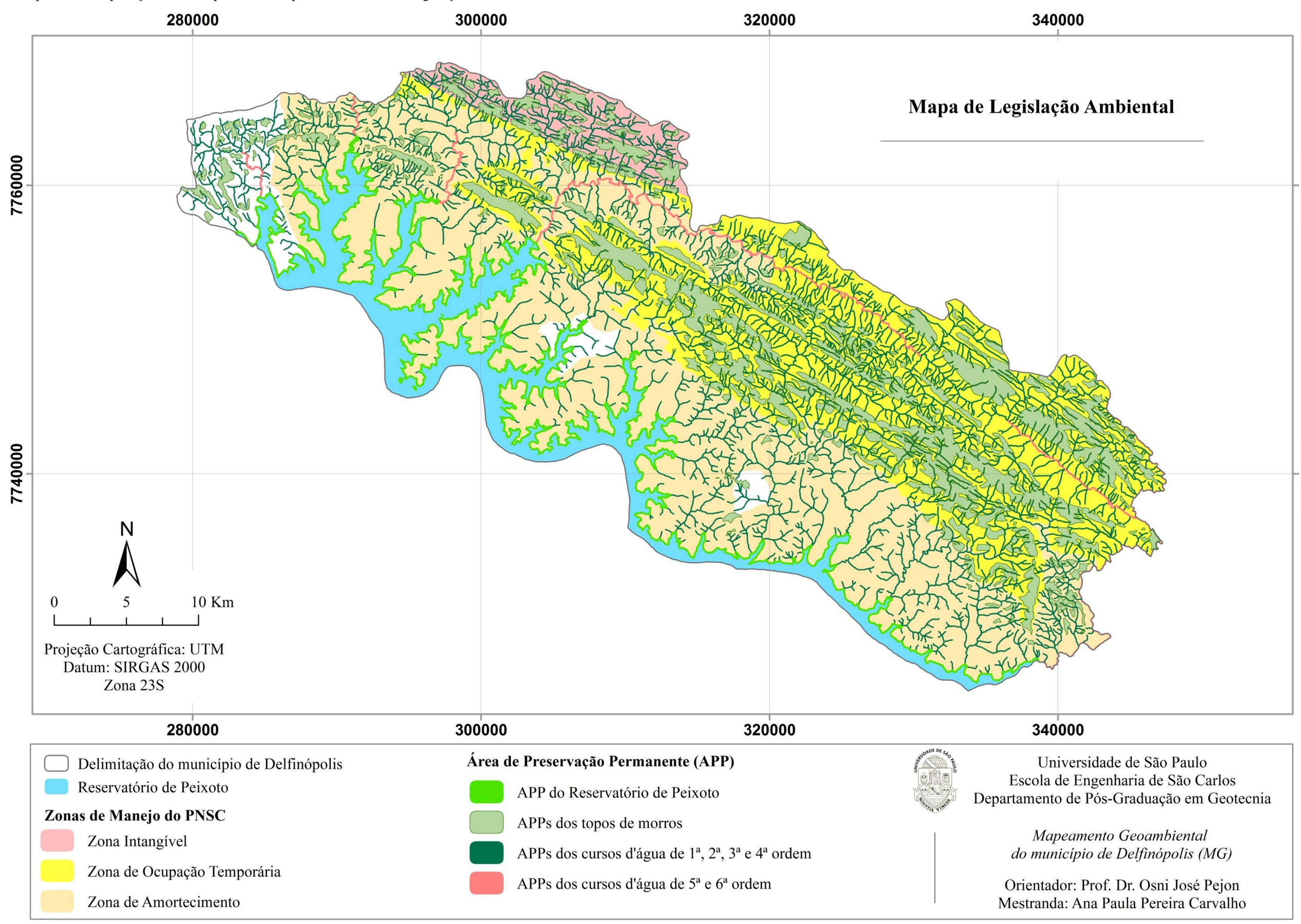





\subsection{Unidades geoambientais e uso e ocupação do solo}

As nove unidades geoambientais (UGs) foram analisadas de forma quantitativa e descritiva quanto ao uso e ocupação do solo.

A UG 1 se destaca como a unidade que apresenta o maior percentual de área ocupada por pastagem, correspondendo a quase $70 \%$. A área de vegetação natural na unidade é relativamente pequena correspondendo $0,82 \mathrm{~km}^{2}$. Esta unidade encontra-se situada na zona de amortecimento do Parque Nacional da Serra da Canastra (PNSC), visto que nesta área o uso do solo depende de licença ambiental do órgão responsável vigente.

Ao contrário da primeira unidade, a UG 2 apresenta 70,78\% de sua área composta por vegetação natural, mais especificamente por $59 \%$ de campo. Esta é a unidade que apresenta o maior percentual de solo exposto, visto que esta área é composta por um material inconsolidado cuja fração granulométrica predominante é areia.

Com relação à UG 3, a classe que mais se destaca é a área agrícola correspondendo $46 \%$ da unidade. A segunda classe que apresenta maior percentual compreende as áreas de vegetação natural $(36,68 \%)$.

Já a UG 4 apresenta um pouco mais da metade de sua área composta por vegetação natural compreendendo a 50,51\%. As áreas agrícolas encontradas na unidade compreendem 31,92\%, com predomínio das plantações de culturas anuais. Com relação ao sistema viário, esta é a única unidade que apresenta estrada pavimentada, sendo que esta se encontra sob responsabilidade do Departamento de Estradas de Rodagens (DER) do estado de Minas Gerais.

Assim como na unidade anterior, a UG 5 também se destaca em área de vegetação natural, respectivamente com a ocupação de campo $\left(50,17 \mathrm{~km}^{2}\right)$, mata $\left(18 \mathrm{~km}^{2}\right)$ e capoeira $\left(0,34 \mathrm{~km}^{2}\right)$. A pastagem encontra-se em maior porcentagem que as culturas, correspondendo $12,84 \%$, enquanto que as áreas agrícolas representam 10,08\%.

A UG 6 é a segunda unidade que apresenta maior percentual quanto a presença de solo exposto e necessita de práticas de recuperação e conservação. Como a UG 5, esta unidade é ocupada por mais áreas de pastagem do que por culturas anuais e permanentes. 
A UG 7 apresenta o maior percentual de área ocupada por estradas (rurais e municipais) comparada com as outras unidades, correspondendo 2,98\% de sua área. A classe dominante desta unidade é a pastagem $(43,27 \%)$, seguida pelas áreas de vegetação natural que compreendem o segundo maior percentual com $36,83 \%$.

Dentre as unidades geoambientais, a UG 8 é a unidade que se destaca quanto a preservação da região, visto que $81,69 \%\left(458,13 \mathrm{~km}^{2}\right)$ da sua área corresponde a vegetação natural que é distribuída em campo $(67,79 \%)$, mata $(13,50 \%)$ e capoeira $(0,40 \%)$. A maior parte desta área está localizada na área não regularizada do PNSC, por isso se encontra também o cultivo de plantações e pastagens $(17,26 \%)$.

A UG 9 é a principal unidade que contribui com as atividades econômicas do município. As atividades agrícolas são desenvolvidas em toda a sua extensão, por este motivo é a unidade que apresenta menor percentual de vegetação natural, enquanto que o maior percentual se concentra no cultivo de culturas anuais e permanentes com $62,20 \%(219,39$ $\mathrm{km}^{2}$ ). Nesta unidade se encontra a área urbana do município de Delfinópolis, a qual representa $1,10 \%$ da área total da unidade.

O mapa de uso e ocupação do solo do município de Delfinópolis é apresentado na Figura 41. A Figura 42 apresenta os gráficos dos percentuais de área das classes do uso e ocupação do solo das nove unidades geoambientais. 
Figura 41 - Uso e ocupação do solo no município de Delfinópolis.

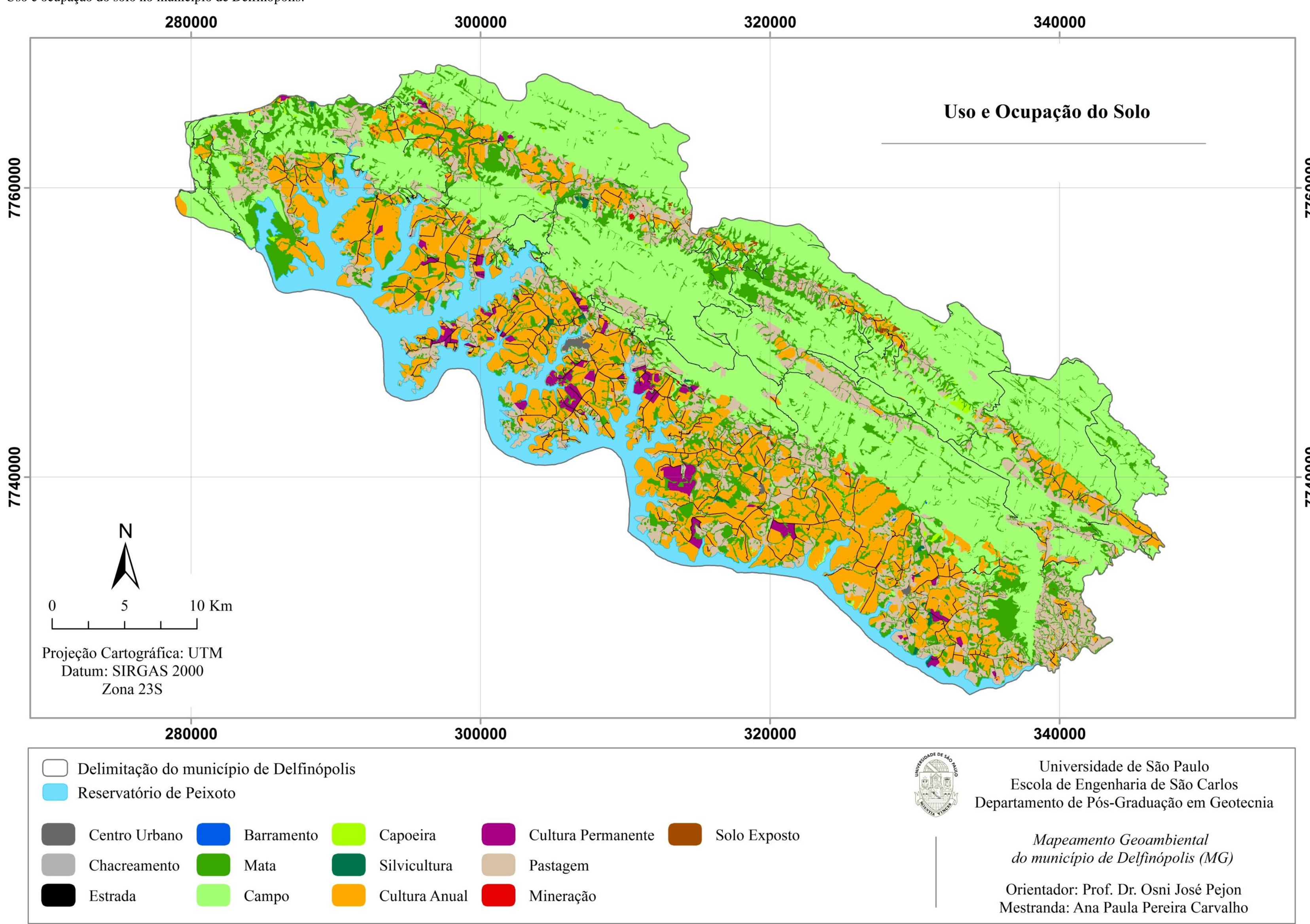



Figura 42 - Percentual das classes de uso e ocupação do solo das unidades geoambientais.

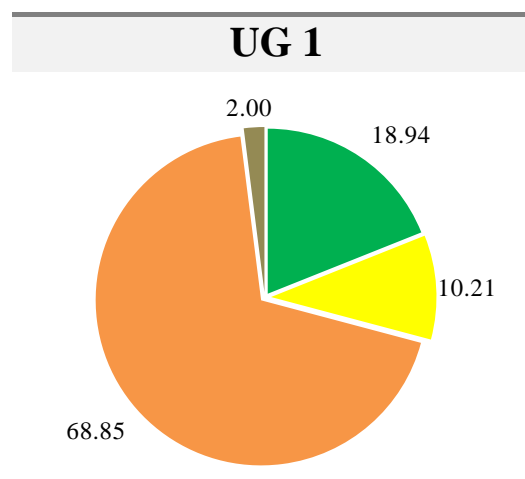

UG 4*

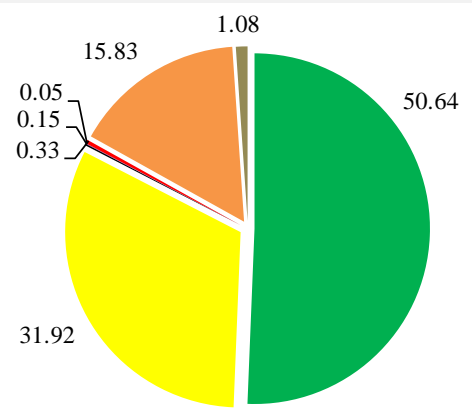

UG 7

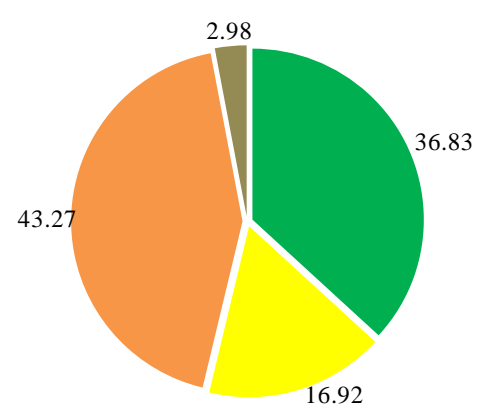

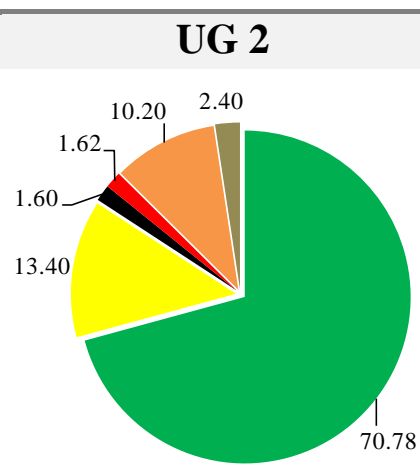

UG 5*

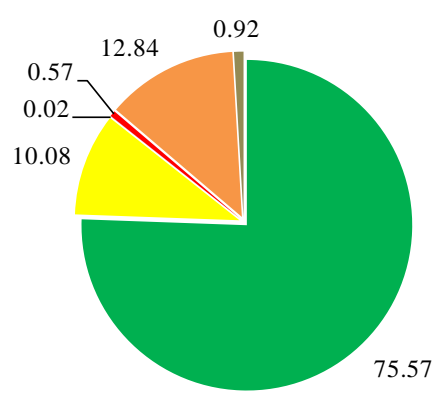

UG 8*
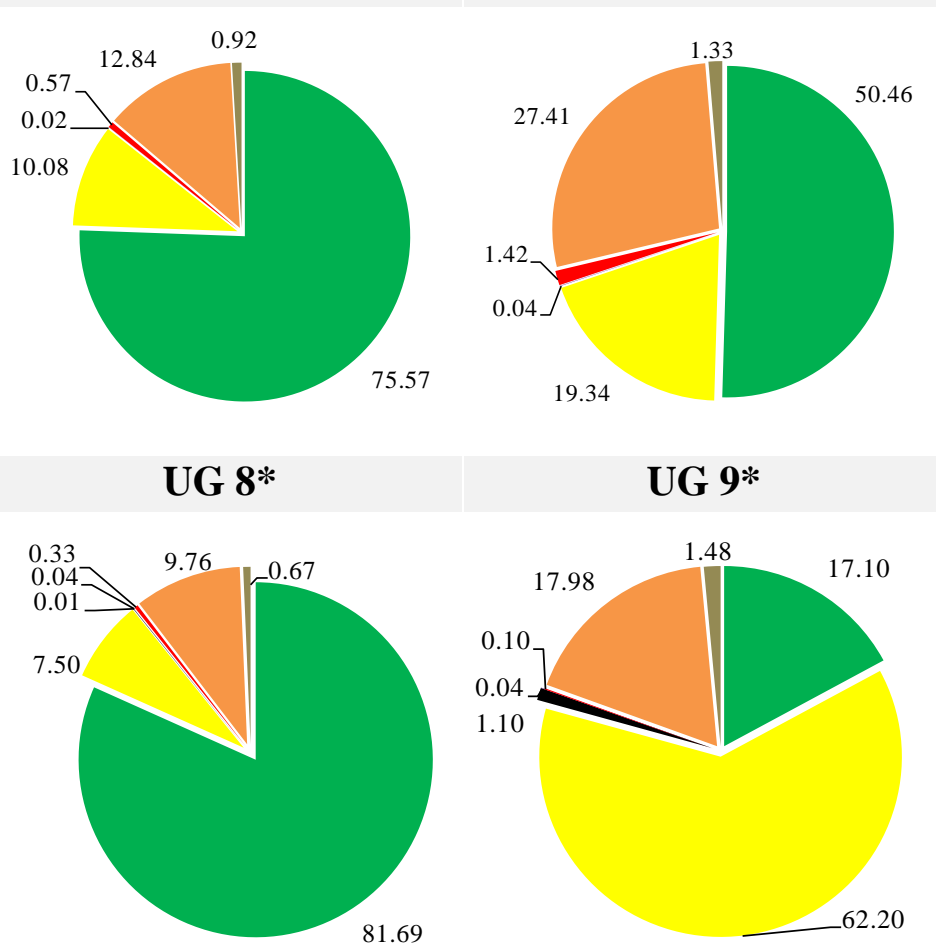

\section{UG 9*}

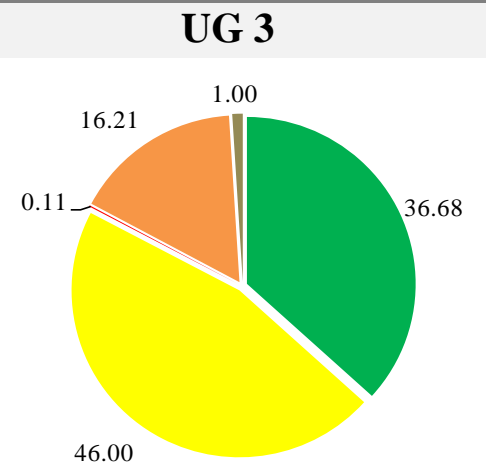

UG 6* 
Conforme mencionado no item 4.2.7.2, foi necessário o estabelecimento de pesos para cada uma das classes do mapa de uso e ocupação do solo, como apresenta a Tabela 55. Os pesos estabelecidos se enquadraram na escala de 1 a 10, conforme proposto na metodologia.

Tabela 55 - Pesos das classes do uso e ocupação do solo da área de estudo.

\begin{tabular}{|c|c|c|c|}
\hline \multicolumn{2}{|r|}{ Classes } & \multicolumn{2}{|c|}{ Pesos } \\
\hline 1 & Área Construída & 10 & Maior \\
\hline 2 & Mineração & 9 & $\begin{array}{l}\text { pressao } \\
\text { antrópica }\end{array}$ \\
\hline 3 & Solo Exposto & 9 & $\cdot$ \\
\hline 4 & Estrada & 8 & . \\
\hline 5 & Atividade Pontual & 8 & . \\
\hline 6 & Pastagem & 7 & $\downarrow$ \\
\hline 7 & Área Agrícola & 7 & Menor \\
\hline 8 & Área de Vegetação Natural & 1 & antrópica \\
\hline
\end{tabular}

A Tabela 56 apresenta o percentual de área de cada classe do mapa de uso e ocupação do solo da área de estudo, visto que estes valores são necessários para a aplicação do ITA.

Tabela 56 - Percentual de área das classes de uso e ocupação do solo nas unidades geoambientais.

\begin{tabular}{|c|c|c|c|c|c|c|c|c|c|}
\hline \multirow{2}{*}{$\begin{array}{c}\text { Classes do } \\
\text { Uso e } \\
\text { Ocupação } \\
\text { do Solo }\end{array}$} & \multicolumn{9}{|c|}{ Unidades Geoambientais (UGs) (\%) } \\
\hline & UG 1 & UG 2 & UG 3 & UG 4 & UG 5 & UG 6 & UG 7 & UG 8 & UG 9 \\
\hline $\begin{array}{c}\text { Área } \\
\text { Construída }\end{array}$ & - & 1,60 & - & 0,15 & - & - & - & 0,04 & 1,10 \\
\hline Mineração & - & - & - & 0,05 & 0,03 & 0,03 & - & 0,07 & - \\
\hline $\begin{array}{c}\text { Solo } \\
\text { Exposto }\end{array}$ & - & 1,62 & 0,11 & 0,28 & 0,54 & 1,39 & - & 0,26 & 0,07 \\
\hline Estrada & 2,00 & 2,40 & 1,00 & 1,08 & 0,92 & 1,33 & 2,98 & 0,67 & 1,49 \\
\hline $\begin{array}{l}\text { Atividade } \\
\text { Pontual }\end{array}$ & - & - & - & 0,05 & 0,02 & 0,04 & - & 0,01 & 0,04 \\
\hline Pastagem & 68,85 & 10,20 & 16,21 & 15,83 & 12,84 & 27,40 & 43,27 & 9,76 & 18,00 \\
\hline $\begin{array}{c}\text { Área } \\
\text { Agrícola }\end{array}$ & 10,21 & 13,40 & 46,00 & 31,92 & 10,08 & 19,34 & 16,92 & 7,50 & 62,20 \\
\hline $\begin{array}{l}\text { Área de } \\
\text { Vegetação } \\
\text { Natural }\end{array}$ & 18,94 & 70,78 & 36,68 & 50,64 & 75,57 & 50,47 & 36,83 & 81,69 & 17,10 \\
\hline
\end{tabular}

A Figura 43 apresenta um esquema ilustrativo da escala de valores relacionados ao nível de degradação conforme estabelecido por Cruz et al. (1998). 
Figura 43 - Intervalos de valores quanto ao nível de degradação.

\begin{tabular}{|c|c|c|c|}
\hline Pouco Degradada & Regular & Degradada & Muito Degradada \\
\hline $0-2,50$ & $2,50-5,00$ & $5,00-7,50$ & $7,50-10,00$ \\
\hline
\end{tabular}

A Tabela 57 apresenta os valores encontrados após o cálculo do índice e as classes a qual as unidades geoambientais foram enquadradas considerando os intervalos de Cruz et al. (1998). O ITA foi calculado através da Equação 10.

$$
I T A=\sum(\% \text { Uso } \times \text { Peso }) / 100
$$

Tabela 57 - Valores do ITA e o enquadramento das unidades geoambientais quanto às pressões antrópicas.

\begin{tabular}{c|c|c}
\hline Unidades Geoambientais & Valores do ITA & Classes \\
\hline UG 1 & 5,88 & Degradada \\
\hline UG 2 & 2,86 & Regular \\
\hline UG 3 & 4,81 & Regular \\
\hline UG 4 & 3,98 & Regular \\
\hline UG 5 & 2,49 & Pouco Degradada \\
\hline UG 6 & 4,01 & Regular \\
\hline UG 7 & 4,82 & Regular \\
\hline UG 8 & 2,11 & Pouco Degradada \\
\hline UG 9 & 6,02 & Degradada \\
\hline
\end{tabular}

Pode-se observar que as unidades degradadas são aquelas que apresentam o maior percentual de suas áreas situadas na zona de amortecimento do PNSC, visto que esta zona apresenta declividades mais baixas, o que favorece o plantio de culturas agrícolas.

Segundo Sousa (2001), outro fator, além da declividade, que contribui para o uso agrícola é a variação litológica, que está diretamente relacionada com a geomorfologia, e que de certa forma se reflete na fertilidade dos solos do município. De acordo com a autora, as regiões de Delfinópolis em que o relevo é mais plano encontram-se as áreas mais férteis compostas por rochas ricas em magnésio, ferro, potássio, cálcio e fósforo.

Além da prática agrícola, outro fator que favorece a degradação, especialmente na unidade UG 9, é a supressão da cobertura vegetal para implementação de infraestruturas 
(chacreamentos) e pastagens a margem do reservatório de Peixoto, danificando sua área de preservação permanente. Outro fator colaborador é a exploração mineraria, com extração de cascalho, quartzito e areia.

As unidades geoambientais que apresentam nível regular de degradação estão concentradas na zona de amortecimento e na zona de ocupação temporária, nesta segunda zona se encontram também populações humanas residentes e as suas respectivas áreas de uso do solo. São dois fatores importantes que proporcionam este médio nível de degradação as unidades (UG 2, UG 3, UG 4, UG 6 e UG 7), o primeiro é a legislação ambiental que restringe as ocupações nesta zona e o segundo é a geomorfologia, pois conforme Sousa (2001) é encontrada nesta região serras com rochas que apresentam grande quantidade de sílica, contribuindo para a baixa fertilidade do solo.

As unidades UG 5 e UG 8 se enquadram no nível de "pouco degradadas", pelo motivo de se situarem em parte na zona intangível e outra parte na unidade de conservação ainda pouco explorada (zona de ocupação temporária).

A Figura 44 apresenta o mapa de classificação das unidades geoambientais com relação aos níveis de degradação causados pela intervenção antrópica. 
Figura 44 - Mapa de classificação das unidades geoambientais quanto ao nível de degradação.

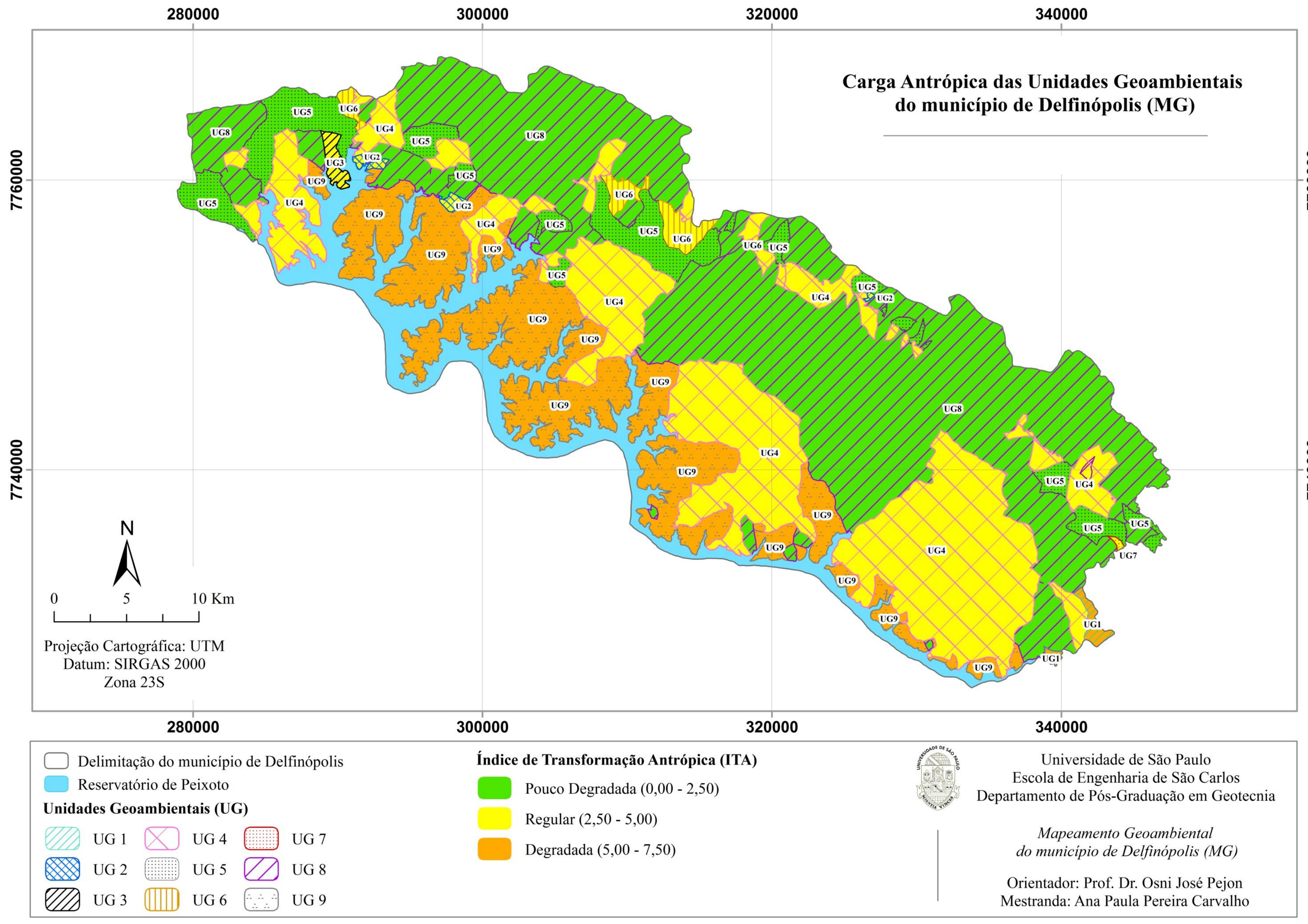





\subsection{Síntese das características das unidades geoambientais e recomendações}

A seguir estão descritas recomendações para cada unidade geoambiental do município de Delfinópolis (MG), vale ressaltar que foram consideradas as características do meio físico incluindo as suscetibilidades e potencialidades, bem como as áreas com restrições legais e o uso e ocupação do solo.

\section{Unidade Geoambiental 1}

Esta unidade não apresenta problemas quanto à ocorrência de erosão, pois se enquadra na classe de baixa suscetibilidade quanto ao surgimento de processos erosivos, pois a textura predominante do solo é silte e argila, compreendendo a 35,63\% da área da unidade. $\mathrm{O}$ que pode contribuir com tal evento é a declividade, visto que a classe deste atributo que mais prevalece na UG 1 varia de $10 \%$ a $30 \%$, sendo considerada, no entanto moderada para o aparecimento de feições erosivas no solo.

Esta unidade está totalmente inserida na zona de amortecimento do Parque Nacional da Serra da Canastra (PNSC), vale lembrar que esta zona de manejo segundo a Lei Federal $n^{\circ}$ 9,985/2000, artigo $2^{\circ}$ (inciso XVIII), é definida pela área que envolve a unidade de conservação, em que as atividades humanas estão sujeitas a normas e restrições específicas, com a finalidade de minimizar os impactos insatisfatórios dentro das limitações da área protegida.

A UG 1 deveria apresentar 21,82\% de área com restrição legal (APPs dos cursos d'água de $1^{\mathrm{a}}, 2^{\mathrm{a}}, 3^{\mathrm{a}}$ e $4^{\mathrm{a}}$ ordem; APPs dos cursos d'água de $5^{\mathrm{a}}$ e $6^{\mathrm{a}}$ ordem; APP do Rio Grande; e APPs dos topos de morros com inclinação média a 25\%). Da área total de APPs, apenas $0,36 \mathrm{~km}^{2}$ é composta por vegetação natural (mata e campo). Com base neste contexto, a unidade possui cerca de $60 \%$ de déficit em áreas ambientais que necessitam ser protegidas sob o ponto de vista legal e ambiental.

Esta unidade contribui fortemente com o setor econômico do município, pois mais de $70 \%$ de sua área é ocupada por pastagem e agricultura. Nesta concepção e com base no cálculo do ITA, a unidade se encontra degradada, devido às atividades antrópicas existentes que contribuem com o processo de transformação natural. Desta forma, são apresentadas a 
seguir algumas recomendações e ações para a unidade UG 1 de maneira a minimizar os efeitos da degradação identificada na unidade.

Principais recomendações:

- Manter o limite da unidade dentro das delimitações da zona de amortecimento, respeitando as normas estabelecidas pelo plano de manejo do PNSC;

- Restringir a ocupação em áreas que apresentam alta suscetibilidade a processo de inundação;

- Realizar manutenção nas estradas para evitar o surgimento de feições erosivas;

- Controlar o manejo das áreas que apresentam alguma potencialidade à produção rural;

- Restaurar as áreas de preservação permanente dos cursos d'água e do Rio Grande (reservatório de Peixoto);

- Realizar controle para evitar processos de desmatamento;

- Continuar a exigir licença ambiental para qualquer atividade implementada mesmo que seja de pequeno porte.

\section{Unidade Geoambiental 2}

A maior parte da unidade UG 2 se encontra na zona de amortecimento da área protegida (Parque Nacional), nesta área os terrenos são planos, com declividades inferiores a 10\%. Esta situação evidencia a possibilidade de ocorrência de inundação, principalmente na região mais baixa da unidade, próxima ao reservatório de Peixoto. Outro problema do ponto de vista ambiental é a predisposição ao surgimento de feições erosivas, devido à textura do solo.

Uma vantagem que a UG 2 apresenta é a conservação da sua vegetação natural, no entanto, mesmo apresentando este aspecto positivo a unidade deve obedecer aos limites das APPs, sendo que apenas $0,59 \mathrm{~km}^{2}$ de mata e campo, compõem as áreas de preservação.

Na unidade $23,60 \%$ da sua área é explorada por pastagens e atividades agrícolas, dessa forma é considerada "regular" com relação ao índice de transformação antrópica. Para a UG2 as recomendações estão dispostas a seguir: 
- Restringir a ocupação nas áreas susceptíveis a processos de inundação e erosão;

- Proibir a implantação de novos chacreamentos ao entorno do reservatório de Peixoto, de forma a preservar e conservar a sua APP, conforme estabelece o Novo Código Florestal (Lei Federal no 12,651/2012);

- Restaurar as áreas de preservação permanente dos cursos d'água e do Rio Grande (reservatório de Peixoto);

- Continuar a exigir licença ambiental para qualquer tipo de atividade, independente do potencial poluidor;

- Recuperar as áreas em que o solo se encontra desprotegido, de modo a evitar processos erosivos;

- Incentivar os produtores rurais para o plantio sustentável de culturas, ou seja, priorizar o uso racional de insumos agrícolas;

- Conservar a área de vegetação natural da unidade com rígido controle para impedir desmatamentos.

\section{Unidade Geoambiental 3}

A UG 3 não apresenta problemas ambientais de grande magnitude, como ocorrência de inundações ou processos erosivos intensos, pois as características geomorfológicas da área a torna menos susceptível a propagação de tais eventos.

Assim como a UG 1, esta área se encontra totalmente inserida na ZAm da unidade de conservação, sendo margeada pelo reservatório de Peixoto (um dos reservatórios artificiais do Rio Grande). Nesta área é permitido o uso e ocupação do solo desde que qualquer alteração no meio físico e biótico seja regularizada pelo órgão ambiental vigente.

A UG 3 contribui fortemente com a economia de Delfinópolis, visto que $46 \%$ da sua área são utilizados para a produção agrícola, dessa forma as intervenções humanas dentro da unidade, faz com que ela apresente um nível de degradação regular. Com base nas análises realizadas as recomendações para a UG 3 são apresentadas a seguir: 
- Não permitir à implantação de chacreamentos a margem do reservatório de Peixoto, respeitando a área de preservação permanente;

- Restaurar as áreas de preservação permanente dos cursos d'água e do Rio Grande (reservatório de Peixoto);

- Continuar a exigir licença ambiental para qualquer atividade a ser implementada, e também para as atividades já existentes;

- Incentivar o reflorestamento nas áreas em que ocorreu supressão de vegetação;

- Recuperar as áreas em que se encontra solo exposto, a fim de evitar problemas como perda de solo, assoreamento, entre outros;

- Incentivar a produção agrícola em áreas que apresentam alto potencial, considerando o manejo sustentável da área.

\section{Unidade Geoambiental 4}

A área da unidade UG 4 apresenta uma moderada tendência à ocorrência de eventos naturais como a inundação e erosão. Estes processos estão relacionados com as características geomorfológicas da área.

Esta unidade apresenta $65,43 \%$ da sua área na ZAm, enquanto que 33,87\% se situam na ZOT. A parte da unidade que sofre mais pressões antrópicas é a porção sul, visto que se encontra o uso mais expressivo do solo, com atividades agrícolas e pastagem. Porém a parte da unidade que se localiza na região norte também utiliza o solo para fins agrícolas, sendo que estas localidades estão dentro das delimitações da zona não regularizada do PNSC.

A UG 4 é a segunda unidade que mais contribui com a atividade econômica do município, visto que mais de 30\% da sua área é destinada a agricultura. Mesmo a unidade apresentando uma carga antrópica regular, ela se destaca na conservação da vegetação natural, com $36,68 \%$ da sua área. A seguir estão sendo informadas as recomendações para a UG 4:

- Realocar a população que reside na zona não regularizada para outra localidade que apresente as condições necessárias que garanta sua sobrevivência;

- Conservar e preservar toda a área do Parque Nacional da Serra da Canastra; 
- Monitorar os desmatamentos como também a prática de queimadas, sendo comum em regiões de bioma cerrado;

- Restaurar e preservar as áreas de preservação permanente dos cursos d'água e do reservatório de Peixoto, levando em consideração a largura mínima que estabelece o Novo Código Florestal (Lei Federal nº 12,651/2012);

- Exigir licença ambiental para qualquer atividade antrópica que modifique o meio natural;

- Recuperar as áreas exploradas por atividades de mineração, além de exigir o Plano de Recuperação de Áreas Degradadas (PRAD), além do monitoramento contínuo da área até atingir novamente sua estabilidade;

- Recuperar as áreas em que se encontra solo exposto, de modo a contribuir para que não ocorram processos erosivos;

- Limitar a ocupação do solo em áreas que apresentam alguma suscetibilidade a processos de inundação ou/e erosão.

\section{Unidade Geoambiental 5}

Com relação à ocorrência de processos naturais que desestabilizam o equilíbrio dinâmico da unidade, a UG 5 se enquadra em baixa a moderada suscetibilidade a erosão e inundação.

A área da UG 5 é dividida quase que igualmente em duas zonas de manejo, a ZAm e a ZOT, correspondendo respectivamente, $50,32 \%$ e $49,68 \%$.

Esta unidade é considerada pouco degradada, a porção da unidade que apresenta interferência humana totaliza em $23,89 \%$ e se concentra principalmente na ZAm, no entanto se encontram também pequenas áreas com presença de culturas anuais e pastagens na ZOT. As recomendações para a unidade são apresentadas abaixo:

- Considerar como ZI toda a área da unidade que abrange a ZOT, devido a apresentar grande analogia dos atributos físicos, como substrato rochoso, declividade e material inconsolidado como as áreas da ZI; 
- Realocar a população que reside na ZOT para outros locais que apresentam as mesmas condições de sobrevivência;

- Conservar e preservar as áreas de vegetação natural em toda a extensão da unidade;

- Proibir as atividades minerárias na zona não regularizada;

- Recuperar e monitorar as áreas exploradas por mineração, além de exigir o PRAD.

\section{Unidade Geoambiental 6}

A unidade UG 6 apresenta pouca tendência ao surgimento de processos erosivos e moderada suscetibilidade a ocorrência de inundação.

A maior parte de sua área se localiza na ZAm, sendo que $27,40 \%$ é ocupada por pastagens, enquanto que 19,34\% é destinada as atividades agrícolas. No entanto, mesmo a unidade apresentando uma área considerável que sofre alterações no seu meio natural, esta se destaca pela conservação da vegetação existente, desse modo a UG 6 é considerada regular em nível de degradação.

Com base neste contexto, o que é recomendado à unidade está citado a seguir:

- Conservar e preservar as áreas florestadas da unidade, com monitoramento para evitar a supressão da vegetação;

- Não permitir a ocupação em áreas que apresentam suscetibilidade à erosão e inundação;

- Realizar o plantio de culturas em curvas de nível nos terrenos que apresentam uma predisposição a ocorrência de feições erosivas;

- Exigir a licença ambiental para qualquer atividade que altere a situação natural da área.

\section{Unidade Geoambiental 7}

A unidade UG 7 apresenta suscetibilidade moderada quanto ao aparecimento de feições erosivas nos terrenos, enquanto que sua área total apresenta baixa suscetibilidade a processos de inundação. 
A UG 7 se concentra totalmente na ZOT, mesmo fazendo parte desta zona não regularizada, a unidade apresenta $63,17 \%$ da sua área ocupada por usos antrópicos, como estradas, pastagens e áreas agrícolas.

Um aspecto relevante desta unidade é a conservação da vegetação natural, pois a UG 7 se destaca como a unidade geoambiental que possui a menor área e, no entanto quase $40 \%$ do seu território são ocupados por matas e campo. A seguir, estão algumas recomendações para o uso racional da área.

- Manter a unidade dentro das limitações da ZOT, respeitando todos os critérios estabelecidos pela legislação e o plano de manejo do PNSC;

- Conservar e preservar as áreas de vegetação natural;

- Restaurar as áreas de preservação permanente dos cursos d'água;

- Monitorar a área para evitar a exploração mineral, de forma a manter o meio físico e biótico estáveis.

\section{Unidade Geoambiental 8}

Com relação a eventos naturais, esta unidade apresenta maior parte da sua área com baixa suscetibilidade à ocorrência de erosão e média predisposição a ocorrência de inundação.

Esta unidade é considerada pouco degradada, um dos motivos principais está pautado na legislação ambiental, visto que $75,12 \%$ de sua área se situam na unidade de conservação do PNSC, sendo que 63,22\% fazem parte da ZOT, vale ressaltar que esta zona é considerada a parte não regularizada da área protegida. O restante $(11,90 \%)$ se localiza na ZI, visto que nesta zona de manejo não é permitido qualquer tipo de atividade antrópica.

Mesmo esta unidade apresentando baixo nível de degradação, 18,05\% da sua área é ocupada por usos que envolvem a intervenção humana como, área urbana, mineração, estradas, barramentos, pastagem e atividade agrícola.

A conservação desta unidade se baseia em algumas recomendações citadas a seguir: 
- Regularizar a área ainda não regularizada do PNSC, visto que maior parte desta unidade se localiza na ZOT, e esta zona apresenta características físicas semelhantes com a ZI (zona regularizada e consolidada do PNSC);

- Indenizar e remanejar a população residente para outras áreas que apresentam as mesmas condições de sobrevivência;

- Não permitir a exploração da área por atividades minerárias;

- Recuperar as áreas de mineração que se encontram ativas e as que estão desativadas, baseadas em critérios definidos nos seus PRAD;

- Monitorar toda a área da unidade para evitar queimadas, intensificando a fiscalização nos períodos de seca.

\section{Unidade Geoambiental 9}

A unidade apresenta mais de $90 \%$ da área com média suscetibilidade à erosão, isso é devido o material inconsolidado que a compõe. Além de o material contribuir com a possibilidade do surgimento de feições erosivas no solo, ele apresenta uma vantagem de deixar a área menos susceptível a ocorrência de inundações, dessa forma apresentando alta capacidade de infiltração.

A UG 9 é a principal unidade responsável pela economia do município de Delfinópolis (MG), visto que $99,41 \%$ da área se concentram na ZAm, a qual permite o uso do solo com posse de licença ambiental. Neste contexto, observa-se que a UG 9 apresenta o maior nível de degradação, com base no cálculo do Índice de Transformação Antrópica (ITA=6,02).

Outro fator que contribui com este processo de degradação é a quantidade de áreas de preservação permanente, visto que em muitas regiões não é respeitado à faixa estabelecida na legislação disposta no Novo Código Florestal. Para a UG 9 estão dispostas algumas recomendações, citadas a seguir:

- Recuperar as áreas de preservação permanente dos cursos d'água e do reservatório de Peixoto;

- Não permitir a implementação de chacreamentos ao longo da margem do reservatório de Peixoto, de modo a evitar danos às áreas de preservação; 
- Exigir licença ambiental para toda atividade realizada, independente do potencial poluidor;

- Recuperar as áreas em que o solo se encontra exposto, de modo a evitar o surgimento de feições erosivas;

- Não permitir a ocupação de áreas que apresentam suscetibilidade à ocorrência de processos erosivos, desde que sejam atividades que protejam a área contra o surgimento ou o agravamento do processo, como o plantio de culturas em curvas de nível;

- Incentivar os produtores a utilizar áreas que apresentam alto potencial à produção rural, considerando o manejo sustentável da área. 



\section{Conclusões}

\subsection{Métodos utilizados}

O método de análise de agrupamentos empregado neste trabalho para a identificação e delimitação das unidades geoambientais do município de Delfinópolis (MG) se mostrou eficaz. A integração da análise morfométrica com informações do meio físico permitiu a delimitação de nove unidades geoambientais com nível de homogeneidade compatível com a escala de mapeamento. Além disso, estas unidades mostraram boa correspondência com o mapa de landforms elaborado por Magri (2013) na mesma escala deste trabalho.

Apesar da área de estudo não corresponder a uma bacia hidrográfica, mas sim ao limite administrativo do município de Delfinópolis, a análise de agrupamentos por bacias de $1^{\mathrm{a}}$ até $4^{\mathrm{a}}$ ordem foi possível. No entanto, a análise das bacias hidrográficas de $1^{\mathrm{a}}$ ordem diferiu das demais ordens de bacias, devido estas primeiras apresentarem áreas muito pequenas e baixa densidade de drenagem. Dessa forma, preferiu-se utilizar diretamente o percentual de área das classes de três atributos do meio físico, assim conclui-se, que a adoção deste critério para a união destas bacias se mostrou apropriada, e não interferiu na análise estatística.

O agrupamento das bacias hidrográficas de $2^{\mathrm{a}}, 3^{\mathrm{a}}$ e $4^{\mathrm{a}}$ ordem através da caracterização morfométrica foi satisfatório, pois os nove índices morfométricos utilizados foram suficientes para uni-las, estes foram escolhidos de maneira a relacionar as variáveis de três tipos de análises (areal, linear e hipsométrica), dessa forma os índices mostraram-se eficientes na representação do relevo. Para todas as análises estatísticas realizadas neste trabalho foi indispensável à utilização das ferramentas do software STATISTICA $13^{\circledR}$, por apresentar uma interface simples, além de se destacar em desempenho e agilidade nos processamentos de grande quantidade de dados.

Nos dendrogramas a linha de fusão de $20 \%$ se mostrou adequada para a união das bacias hidrográficas que apresentam mínima heterogeneidade quanto aos aspectos do meio físico, pois permitiu um agrupamento bastante expressivo das bacias. No entanto, para a identificação dos grupos de bacias que apresentam maior nível de dissimilaridade, optou-se pela linha de fusão estabelecida em $80 \%$, que também se mostrou apropriada para esta finalidade. 
A análise integrada das unidades geoambientais com as zonas de manejo do Parque Nacional da Serra da Canastra possibilitou retratar se a delimitação das unidades apresenta compatibilidade com as zonas quanto aos seus usos e manejo. A integração destas delimitações dependeu dos recursos do software Arc GIS 10.0 ${ }^{\circledR}$, que por sua vez mostrou-se essencial na análise comparativa destas duas delimitações (unidades e zonas).

O Arc GIS $10.0^{\circledR}$ também foi fundamental no mapeamento e quantificação das áreas de preservação permanente. A metodologia aplicada proporcionou intersectar as APPs com a vegetação natural, resultando em uma análise favorável para a identificação do percentual de déficit de áreas com restrição legal de cada unidade.

O método empregado para verificar a pressão antrópica de cada unidade mostrou-se eficiente e de simples aplicação. Os valores obtidos pelo Índice de Transformação Antrópica (ITA) foram pertinentes com os usos do solo em cada área. Esta análise foi essencial para identificar o nível de degradação, assim como para a proposição das recomendações visando minimizar os impactos negativos oriundos das ações humanas.

\subsection{Produtos elaborados}

Após a delimitação das nove unidades geoambientais do município, e da integração destas áreas com as zonas de manejo do PNSC, foi possível identificar algumas analogias quanto ao uso e manejo destes dois limites (unidades e zonas), como é o caso das unidades UG 1 e UG 3, que se encontram totalmente inseridas em uma única zona de manejo, mais especificamente na ZAm. Outra observação importante, considerada após o mapeamento, foi à semelhança das características físicas do ponto de vista geológico-geotécnico das ZI e ZOT, pois estas duas zonas apresentam a maior parte de suas áreas situadas na unidade UG 8. Já as unidades (UG 2, UG 4, UG 5, UG 6 e UG 7) são as que menos apresentaram concordância com os limites das zonas de manejo, no entanto, elas poderão servir para orientar na atualização do zoneamento do PNSC.

A análise das unidades geoambientais frente às áreas que apresentam restrição legal proporcionou identificar que nenhuma das unidades obedece totalmente os limites das áreas de preservação permanente previstas em lei, sendo assim estas áreas apresentam outros usos, como exemplo, as culturas agrícolas, pastagens e chacreamentos. Dentre as unidades, a UG 5 é a que mais condiz com o que estabelece a legislação, respeitando 86,23\% do total de APPs 
dentro do seu limite ocupado por vegetação natural. Enquanto que a UG 9 se destaca com o menor percentual correspondendo a apenas $28,19 \%$ do total dos quatro tipos de APPs mapeadas. Um dos principais motivos que leva esta unidade a apresentar este percentual é o fator topográfico da área, ou seja, a unidade apresenta baixas declividades, o que proporciona maior facilidade de plantio e colheita das culturas, dessa forma a produção agrícola acaba invadindo os limites das APPs para a realização destas atividades.

Com relação à degradação das unidades geoambientais, o índice de transformação antrópica (ITA) calculado mostrou que as unidades UG 5 e UG 8 apresentam os menores níveis de degradação, enquanto que a UG 1 e a UG 9 apresentam os valores mais altos do ITA, correspondendo respectivamente a 5,88 e 6,02. As demais unidades com base nos usos e ocupação do solo se enquadraram na classe intermediária (regular). Pode-se observar também que os valores obtidos através do índice estão de certa forma associados com as restrições legais impostas pelas zonas de manejo do PNSC, ou seja, nas ZI e ZOT o nível de degradação é menor quando comparado com as unidades que apresentam maior área situadas na ZAm, sendo que nesta zona é permitido o uso e ocupação do solo através de licença ambiental.

Como sugestão para futuros trabalhos recomenda-se realizar o mapeamento geoambiental considerando o limite de bacias hidrográficas e não o limite administrativo de municípios, pelo fato destas delimitações nem sempre coincidirem, o que poderá interferir na análise das bacias hidrográficas que ultrapassam a área do município. Além disso, considerar todas as bacias hidrográficas inferiores a $4^{\mathrm{a}}$ ordem de ramificação para o cálculo dos índices morfométricos, de modo a obter maior precisão nas delimitações das unidades geoambientais.

Sugere-se também que para a análise de agrupamentos das bacias de $1^{\mathrm{a}}$ ordem, assim como para as demais ordens de bacias, fazer uso de mais atributos do meio físico que estejam associados à morfometria e no caso dos materiais inconsolidados, além do aspecto textural, utilizar também dados da espessura e do perfil de alteração do solo. 



\section{REFERÊNCIAS BIBLIOGRÁFICAS}

ABBOUD, I. A.; NOFAL, R. A. Morphometric analysis of wadi Khumal basin, western coast of Saudi Arabia, using remote sensing and GIS techniques. Journal of African Earth Sciences, v. 126, p.58-74, 2017.

AKINWUMIJU, A. S.; OLORUNFEMI, M. O. Morphometric Analyses of Osun Drainage Basin, Southwestern Nigeria. Journal of Geography and Geology, v. 8, n. 4, p.9-22, 2016.

ALMEIDA, C. N. R. de. Estudo Geoambiental da Região da Serra da Canastra - MG: Potencialidades e Restrições ao Uso Turístico. 2014. 283 f. Dissertação (Mestrado) - Curso de Geotecnia, Universidade de São Paulo, São Carlos, 2014.

AMORIM, H. R. de. Estudo dos atributos do meio físico como base para o zoneamento geoambiental da região de influência do reservatório da usina hidroelétrica de Caconde (SP), escala: 1:50.000, com uso de geoprocessamento. 2003. 215 f. Dissertação (Mestrado) - Curso de Geotecnia, Universidade de São Paulo, São Carlos, 2003.

ANA. Agência Nacional de Águas. O comitê de bacia hidrográfica: o que é e o que faz?. Brasília: SAG, 2011. v. 1, p. 64.

ANGILLIERI, M. Y. E. Morphometric characterization of the Carrizal basin applied to the evaluation of flash floods hazard, San Juan, Argentina. Quaternary International, v. 253, p.74-79, 2012.

ANTONELI, V; THOMAZ, E. L. Caracterização do meio físico da bacia do Arroio Boa Vista, Guamiranga-PR. Rev. Caminhos da Geografia, Uberlândia, v.8, n.21, p46-58, 2007.

AUGUSTO FILHO, O. Sistemas de Informações Geográficas aplicados à Engenharia Ambiental. In: CALIJURI, Maria do Carmo; CUNHA, D. G. F. Engenharia

Ambiental: Conceitos, Tecnologia e Gestão. Rio de Janeiro: Elsevier, 2013. Cap. 25. p. 643667.

ÁVILA, R. D.; MALHEIROS, T. F. O Sistema Municipal de Meio Ambiente no Brasil: avanços e desafios. Saúde Soc, São Paulo, v. 21, p.33-47, 2012.

BANZATO, B. de M. Análise da Efetividade das Unidades de Conservação Marinhas de Proteção Integral do Estado de São Paulo. 2014. 162 f. Dissertação (Mestrado) - Curso de Ciência Ambiental, Universidade de São Paulo, São Paulo, 2014.

BATISTELA, T. S. O Zoneamento Ambiental e o Desafio da Construção da Gestão Ambiental Urbana. 2007. 146 f. Dissertação (Mestrado) - Curso de Arquitetura e Urbanismo, Universidade de Brasília, Brasília, 2007.

BERNARDY, R. J. O Planejamento Urbano de Pequenos Municípios com Base no Plano Diretor. Desenvolvimento em Questão, v. 11, n. 22, p.4-34, 2013. 
BISWAS, S. S. Analysis of GIS Based Morphometric Parameters and Hydrological Changes in Parbati River Basin, Himachal Pradesh, India. Journal of Geography \& Natural

Disasters, v. 6, n. 2, p.1-8, 2016.

BRAGA, R. Política urbana e gestão ambiental: considerações sobre o plano diretor e o zoneamento urbano. In: CARVALHO, P. F.; BRAGA, R. Planejamento Territorial e Geoprocessamento. Rio Claro: Unesp, 2001. p. 95-109.

BRANDÃO, M. H. de M. Índice de Degradação Ambiental na Bacia Hidrográfica do Rio do Peixe - PB. 2005. 136 f. Tese (Doutorado) - Curso de Geologia Sedimentar e Ambiental, Universidade Federal de Pernambuco, Recife, 2005.

BRASIL. Lei Federal n ${ }^{\circ}$ 9.433, de 8 de janeiro de 1997. Política Nacional de Recursos Hídricos. Brasília, 1997.

Lei Federal $n^{\circ}$ 6.938, de 31 de janeiro de 1981. Política Nacional do Meio

Ambiente. Brasília, 1981.

Lei Federal $n^{\circ}$ 9.985, de 18 de janeiro de 2000. Sistema Nacional de Unidades de Conservação da Natureza.

Resolução CONAMA no 302, de 20 de março de 2002. Parâmetros, definições e limites de Áreas de Preservação Permanente de reservatórios artificiais e o regime de uso do entorno.

Estatuto da cidade: guia para implementação pelos municípios e cidadãos: Lei Federal $\mathrm{n}^{\circ} 10.257$, de 10 de julho de 2001, que estabelece diretrizes gerais da política urbana. Brasília: Câmara dos Deputados, 2001, 265p.

Lei Federal nº 10.257, de 10 de janeiro de 2001. Estatuto da Cidade.

Defesa Civil.

Lei Federal n ${ }^{\circ}$ 12.608, de 10 de abril de 2012. Política Nacional de Proteção e

. Lei Federal nº 12.651, de 25 de janeiro de 2012. Novo Código Florestal.

Decreto Federal no 84.017/1979, de 21 de setembro de 1979. Regulamento dos Parques Nacionais.

BRUBACHER, J. P.; OLIVEIRA, G. G. de; GUASSELLI, L. A. Suscetibilidade de enchentes a partir da análise das variáveis morfométricas na bacia hidrográfica do rio dos Sinos/RS. In: SIMPÓSIO BRASILEIRO DE SENSORIAMENTO REMOTO, 15., 2011, Curitiba. Anais... . Curitiba: INPE, 2011. p. 1279 - 1286.

CALDERANO FILHO, B. et al. Estudo Geoambiental do Município de Bom Jardim - RJ, com Suporte de Geotecnologias: Subsídios ao Planejamento de Paisagens Rurais Montanhosas. Sociedade \& Natureza,Uberlândia, v. 22, n. 1, p.55-73, 2010.

CÂMARA, G.; MEDEIROS, J. S. Geoprocessamento em Projetos Ambientais. 1 ed. São José dos Campos: INPE, 1998.v.único.190p. 
CÂMARA, G.; MONTEIRO, A. M. V. Conceitos Básicos da Ciência da Geoinformação. In: CÂMARA, G.; DAVIS, C.; MONTEIRO, A. M. V. Introdução à Ciência da Geoinformação, São José dos Campos: INPE, Cap. 2, 2004.

CARMO, E. J. do. Avaliação dos interpoladores krigagem e topo to raster na geração de modelos digitais de elevação a partir de dados batimétricos. 2014. 95 f. Dissertação (Mestrado) - Curso de Ciências, Pós-graduação em Engenharia Civil, Universidade Federal de Viçosa, Viçosa, 2014.

CAVAlCANTI, A. P. B. Implantação de Programas de Manejo e Plano de Gestão Ambiental em Pequenas Comunidades. Sociedade \& Natureza, Uberlândia, v. 3, n. 22, p.539-550, 2010.

CAZULA, L. P.; MIRANDOLA, P. H. Bacia hidrográfica - conceitos e importância como unidade de planejamento: um exemplo aplicado na bacia hidrográfica do Ribeirão Lajeado/SP - Brasil. Revista Eletrônica da Associação dos Geógrafos Brasileiros, Lagoas, n. 12, p.101$124,2010$.

CEMIN, G. et al. Proposta Metodológica para a elaboração de um Zoneamento

Ambiental. Revista Brasileira de Cartografia, v. 3, n. 64, p.301-316, 2012.

CENDRERO, A. Environmental Geology of the Santander Bay Area, Northern Spain. Environmental Geology, New York, v. 1, p.97-114, 1975.

CETEC - Fundação Centro Tecnológico de Minas Gerais. Mapa de Geomorfologia do Estado de Minas Gerais. Belo Horizonte: CETEC, 1981.

CETEC - Fundação Centro Tecnológico de Minas Gerais. Mapa de Solos do Estado de Minas Gerais. Belo Horizonte: CETEC, 1981.

CHEN, C.; YU, F. Morphometric analysis of debris flows and their source areas using GIS. Geomorphology, v. 129, p.387-397, 2011.

CHRISTOFOLETTI, A. Geomorfologia. 2. ed. São Paulo: Edgard Blücher, 1980.

CNR - Department of Natural Resources and Environment. Croajingolong National Park Management Plan. Victoria: 1996. 46 p.

COELHO, A. L. N. Sistema de Informações Geográficas (SIG) como Suporte na Elaboração de Planos Diretores Municipais. Caminhos de Geografia, Uberlândia, v. 10, n. 30, p.93-110, 2009.

COELHO, A. M.; ALVES, M. da G.; OLIVEIRA, O. O. de, 13, 2007, Florianópolis. O uso de técnicas de geoprocessamento e mapeamento geológico-geotécnico na elaboração do mapa de potencial de uso e ocupação do solo do município de Itaperuna/RJ.

Florianópolis: Simpósio Brasileiro de Sensoriamento Remoto, 2007. 2447-2454 p.

COLLARES, E. G. Avaliação de alterações em redes de drenagem de microbacias como subsídio ao zoneamento geoambiental de bacias hidrográficas: aplicação na bacia 
hidrográfica do rio Capivari - SP. Tese (Doutorado). Escola de Engenharia de São Carlos, Universidade de São Paulo, São Carlos, 2000.

COLLARES, A. C. Z. B. et al. Aspectos Metodológicos: Hidrologia. In: COLLARES, E. G. Zoneamento Ambiental das Sub-Bacias Hidrográficas dos Afluentes Mineiros do Médio Rio Grande. Passos: Edifesp, 2013. Cap. 16. v.1. p. 163-171.

COLLARES, E. G.; GOMES, D. M. Aspectos dos Meios Físico e Biótico: Geologia. In: COLLARES, E. G. Zoneamento Ambiental das Sub-Bacias Hidrográficas dos Afluentes Mineiros do Médio Rio Grande. Passos: Edifesp, 2013. Cap. 6. v.3. p. 154-164.

COLLARES, E. G.; GOMES, D. M.; SANTOS, B. M. dos. Aspectos Metodológicos: Compartimentação em macrounidades e unidades ambientais. In: COLLARES, E. G. Zoneamento Ambiental das Sub-Bacias Hidrográficas dos Afluentes Mineiros do Médio Rio Grande. Passos: Edifesp, 2013. Cap. 4. v.1. p. 49-62.

CONCEIÇÃO, R. S. da; COSTA, V. C.da. A cartografia e novas tecnologias: conceitos e evolução das geotecnologias. In: CONCEIÇÃO, R. S. da; COSTA, V. C. da. Cartografia e Geoprocessamento. Rio Claro: Fundação CECIERJ, 2011. p. 209-231.

COSTA, H. S. de M.; CAMPANTE, A. L. G.; ARAÚJO, R. P. Z.de. A Dimensão Ambiental nos Planos Diretores de Municípios Brasileiros: Um Olhar Panorâmico Sobre a Experiência Recente. In: SANTOS JUNIOR, O. A.dos; MONTANDON, D. T. Os Planos Diretores Municipais Pós-Estatuto da Cidade: balanço crítico e perspectivas. Rio de Janeiro: Letra Capital, 295. p. 173-217, 2011.

CPRM - Serviço Geológico do Brasil. Mapa Geológico do Estado de Minas Gerais. CPRM, 2014.

CRUZ, C. B. M. et al. Carga Antrópica da Bacia Hidrográfica da Baía de Guanabara. In: IX SIMPÓSIO BRASILEIRO DE SENSORIAMENTO REMOTO, 9., 1998,

Santos. Anais. Santos: INPE, 1998. p. 99 - 109.

DAL'ASTA, A. P. Elaboração do Zoneamento Geoambiental para o Perímetro Urbano de Santa Maria - RS. 2009. 176 f. Dissertação (Mestrado) - Curso de Geografia, Universidade Federal de Santa Maria, Santa Maria, 2009.

DAVIS, J.C. Statistics and data analysis in geology. 2ed. USA. John Wiley \& Sons. 1986.

DEGUIGNET, M. et al. United Nations List of Protected Areas. Cambridge: UNEPWCMC, 2014. 30 p.

DE NARDIN, D.; ROBAINA, L. E. de S. Zoneamento Geoambiental no Oeste do Rio Grande do Sul: Um Estudo em Bacias Hidrográficas em Processo de Arenização. Sociedade \& Natureza, Uberlândia, v. 22, n. 3, p.487-502, 2010.

DEVI, S.; GOSWAMI, D. C. Morphometric characterization of Gayung and Sipu sub-basins of the Subansiri River of the Eastern Himalayas. International Journal Of Geomatics And Geosciences, v. 5, n. 3, p.482-491, 2015. 
DIAS, C. C. Avaliação Geoambiental na Região do Médio Rio Grande. 2013. 395 f.

Dissertação (Mestrado) - Curso de Geotecnia, Departamento de Geotecnia, Universidade de São Paulo, São Carlos, 2013.

DIAS, D. F.; TRENTIN, R.; SCCOTI, A. A. V. Zoneamento Geoambiental para o Município de Mata/RS: Síntese das Potencialidades e Fragilidades. Revista do Departamento de Geografia - USP, v. 30, p.132-148, 2015.

DORNELES, A. C. B. O Zoneamento e a sua Importância como um Instrumento de Planejamento Urbano. Cadernos da Escola de Direito e Relações Internacionais, Curitiba, v. 1, n. 13, p.452-467, 2010.

EASTMAN, J. E. Manual ao usuário: Introdução e exercícios tutoriais. Versão em português para o Idrisi for Windows. Eds: Hasenack, H; Weber, E. 1998. UFRGS: Centro de Recursos Idrisi, 1992, 224p.

FARINA, F. C. Abordagens sobre as técnicas de geoprocessamento aplicadas ao planejamento e gestão urbana. Cadernos Ebape.br, v. 4, n. 4, p.1-13, 2006.

FELL, R. et al. Geotechnical Engineering of Dams. Sydney: Crc Press, 2014. 901 p.

FELTRAN FILHO, A.; FÁTIMA DE LIMA, E. Considerações Morfométricas da Bacia do Rio Uberabinha - Minas Gerais. Sociedade \& Natureza, Uberlândia, v. 19, n. 1, p.65-80, 2007.

FERREIRA, C. J. et al. Definição e análise dos indicadores de degradação ambiental associada às áreas mineradas no município de Caraguatatuba, SP. In: CONGRESSO BRASILEIRO DE GEOLOGIA DE ENGENHARIA E AMBIENTAL, 12., 2008, São Paulo. Anais... . São Paulo: ABGE, 2008. p. 1 - 11.

FIRJAN. IFDM 2015 - Minas Gerais. Disponível em:

<http://www.firjan.com.br/ifdm/downloads/ >. Acesso em: 22 de março de 2016.

FLORENZANO, T. G. Iniciação em Sensoriamento Remoto. 3. ed. São Paulo: Oficina de Textos, 2007. $128 \mathrm{p}$.

FOLETO, E. M.; ZIANI, P. Zoneamento Ambiental e Diretrizes para o Plano de Manejo do Parque do Morro em Santa Maria/RS. Revista do Departamento de Geografia, Universidade de São Paulo, v. 26, p.15-37, 2013.

FOLHARINI, S. de O.; OLIVEIRA, R. C. de. Proposta de zoneamento ambiental para o município de São José do Rio Pardo-SP. Geografia, Londrina, v. 22, n. 1, p.95-116, 2013.

FRANÇA, D. de A.; IBANEZ, D. M.; FERREIRA, N. J., 12, 2005, Goiânia. Detecção de mudanças e elaboração de cartas de unidades de paisagem e de uso do solo: o exemplo de São José dos Campos - SP. Goiânia: Simpósio Brasileiro de Sensoriamento Remoto, 2005. p. 3755-3761. 
FRANÇA, G. V. Interpretação fotográfica de bacias e de redes de drenagem aplicada a solos da região de Piracicaba. Piracicaba. Tese (Doutorado). Escola Superior de Agronomia Luiz de Queiroz - Universidade de São Paulo. 151p. 1968.

GANDOLFI, P. A. Investigações sedimentológicas, morfométricas e físio-químicas nas bacias do Moji-Guaçu, do Ribeira e do Peixe. São Carlos. Tese (Livre Docência). Universidade de São Paulo, 108p. 1971.

GENELETTI, D.; VAN DUREN, I. Protected area zoning for conservation and use: A combination of spatial multicriteria and multiobjective evaluation. Landscape And Urban Planning, A, v. 85, p.97-110, 2008.

GOMES MACHADO, E. Democracia e planejamento urbano na revisão do Plano Diretor de Fortaleza (2002-2008). Reflexión Política, Bucaramanga, v. 16, n. 31, p.64-78, 2014.

GONÇALVES JUNIOR, C. A.; RODRIGUES, E. A. G. Relação entre as atividades econômicas e a qualidade ambiental nos municípios do estado do Paraná. Revista de La Facultad de Ciencias Econômicas, Resistencia, n. 10, p.63-82, 2013.

GRECCHI, R. C. Zoneamento Geoambiental da Região de Piracicaba-SP, com auxílio de Geoprocessamento. 1998. 132f. Dissertação (Mestrado). Universidade de São Paulo, São Carlos, 1998.

HAIR, J. F. J. et al. Análise Multivariada de Dados. Porto Alegre: Bookman, 2009. 687 p.

HALKIDI, M.; BATISTAKIS, Y.; VAZIRGIANNIS, M. On Clustering Validation Techniques. Journal of Intelligent Information Systems, v. 2-3, p.107-145, 2001.

HOCKINGS, M. et al. Evaluating Effectiveness: A framework for assessing management effectiveness of protected areas. 2. ed. Gland: IUCN, 2006. 105 p.

HOFF, R.; LEITE, J. C.; ZOUAIN, R. N. A. Aplicação de Técnicas de Sensoriamento Remoto e Geoprocessamento como Apoio a Estudos Geológicos e Geotécnicos para Gestão Ambiental do Município de Três Cachoeiras, Litoral Norte do RS, Brasil. Revista LusoBrasileira de Geotecnia, Lisboa,n. 118, p. 89-113, 2010.

HORTON, R.E. Erosional development of streams and their drainage basins: hydrophysical approach to quantitative morphology. Geological. Society America Bulletin, 56(3), 1945, p. 275-370.

HUISMAN, O.; BY, R. A. de. Principles of Geographic Information Systems. Enschede: ITC, 2009. $540 \mathrm{p}$.

IBAMA - Instituto Brasileiro do Meio Ambiente e do Desenvolvimento Sustentável. Plano de Manejo do Parque Nacional da Serra da Canastra. Ministério do Meio Ambiente: Brasília-DF, 2005, 828 p.

Plano de Manejo do Parque Nacional da Serra da Canastra (Resumo Executivo). Ministério do Meio Ambiente: Brasília-DF, 2005, 94 p. 
Plano de Prevenção aos Incêndios Florestais Parque Nacional da Serra da Canastra. Ministério do Meio Ambiente: São Roque de Minas - MG, 2005, 24 p.

Roteiro Metodológico de Planejamento: Parque Nacional; Reserva Biológica; Estação Ecológica. Edições Ibama, 2002. 135 p.

IBGE. Biomas. 2016. Disponível em: <ftp://geoftp.ibge.gov.br/mapas_interativos/>. Acesso em: 01 abr. 2016.

IBGE cidades - Informações estatísticas. 2014. Disponível em:

<http://www.cidades.ibge.gov.br/xtras/uf.php?lang=\&coduf=31\&search=minas-gerais >. Acesso em 08 de março de 2016.

Informações estatísticas. 2010. Disponível em:

<http://www.cidades.ibge.gov.br/xtras/uf.php?lang=\&coduf=31\&search=minas-gerais $>$. Acesso em 23 de maio de 2016.

IBRAHIM, A.; HAJJ, M. A.; HAGE, M. E. Use of Geomatic Approaches to Characterize Arqa River Basin: A Typical Coastal Lebanese River. Open Journal of Modern Hydrology, v. 5, p.45-57, 2015.

ICMBio - Instituto Chico Mendes de Conservação da Biodiversidade. Plano de Manejo do Parque Nacional da Serra dos Órgãos. Ministério do Meio Ambiente: Brasília - DF, 2008, $374 \mathrm{p}$.

Plano de Manejo do Parque Nacional de Itatiaia. Ministério do Meio Ambiente: Brasília - DF, 2013.

JAVED, A.; KHANDAY, M. Y.; AHMED, R. Prioritization of Sub-watersheds based on Morphometric and Land Use Analysis using Remote Sensing and GIS Techniques. Journal of The Indian Society of Remote Sensing, N, v. 37, p.261-274, 2009.

JHA, R.; MURTHY, K.V.B. An inverse global environmental Kuznets curve. / Journal of Comparative Economics, v. 31, p.352-368, 2003.

KAZMIERCZAK, M. L.; SEABRA, F. B. Índice de susceptibilidade de degradação ambiental [ISDA] em áreas do cerrado paulista. In: SIMPÓSIO BRASILEIRO DE SENSORIAMENTO REMOTO, 13., 2007, Florianópolis. Anais... . Florianópolis: INPE, 2007. p. 2745 - 2752.

KHAWLIE, M. R. 'Hot spots' and 'sensitive areas': Contribution of remote sensing to geoenvironmental mapping in Lebanon. In: BOBROWSKY, Peter T. Geoenvironmental Mapping: Methods, Theory and Practice. Tokio: Balkema, 2002. p. 223-238.

LADWIG, N. I. O Sistema de Informação Geográfica para o Planejamento e a Gestão Sustentável do Turismo. Revista Gestão e Sustentabilidade Ambiental, Florianópolis, v. 1, n. 1, p.19-32, 2012.

LANA, C. E.; ALVES, J. M. de P.; CASTRO, P. de T. A. Análise morfométrica da bacia do Rio do Tanque, MG - Brasil. Revista Escola de Minas, Ouro Preto, v. 54, n. 2, 2001. 
LANDIM, P. M. B. Análise Estatística de Dados Geológicos Multivariados. São Paulo: Oficina de Textos, 2011.208 p.

LEITE, B. S. Caracterização do Meio Físico em Bacias Hidrográficas com Suportes de Sensoriamento Remoto e Geoprocessamento. 2013. 46 f. Dissertação (Mestrado) - Curso de Geografia, Universidade Estadual Paulista, Rio Claro, 2013.

LIMA, S. C. B. de. Análise das Pressões Antrópicas e Atendimento a Legislação Ambiental Aplicável no Maciço Gericinó-Mendanha-RJ. 2008. 78 f. Dissertação (Mestrado) - Curso de Gestão Ambiental, Instituto de Geociências, Niterói, 2008.

LISBOA, A. de M.; FERREIRA, G. C. Zoneamento Geoambiental aplicado ao Planejamento da Gestão Ambiental e Territorial do Município de Colorado D’Oeste, RO. Geociências, São Paulo, v. 30, n. 2, p.219-235, 2011.

LIU, W. T. H. Aplicações de Sensoriamento Remoto. São Paulo: Editora Uniderp, 2007.

LONGLEY, P. A. et al. Sistemas e Ciência da Informação Geográfica. 3. ed. Porto Alegre: Bookman, 2013. 540p.

LOPES, J. L. de S.; CESTARO, L. A.; KELTING, F. M. S. Zoneamento Ambiental como Instrumento de Uso e Ocupação do Solo do Município de Aquiraz-CE. B.G.G, Goiânia, v. 32, n. 1, p.93-104, 2012.

LORANDI, R.; CANÇADO, C. J. Parâmetros físicos para gerenciamento de bacias hidrográficas. In: SCHIAVETTI, A.; CAMARGO, A. F. M. Conceitos de Bacias Hidrográficas: Teorias e Aplicações. Ilhéus: Editus, 2002. Cap. 2. p. 37-65.

MAGRI, R. A. F. Elaboração da Carta de Potencial ao Escoamento Superficial das Águas nas Sub-bacias Hidrográficas dos Afluentes Mineiros do Médio Rio Grande MG. Monografia (Graduação em Engenharia Ambiental) - Universidade do Estado de Minas Gerais, Fundação de Ensino Superior de Passos, Passos: 2010.

MAGRI, R. A. F. Análise da suscetibilidade à erosão da região do Médio Rio Grande (MG). 2013. 232 f. Dissertação (Mestrado) - Curso de Geotecnia, Universidade de São Paulo, São Carlos, 2013.

MARSHALL, K. et al. Tongariro National Park Management Plan. 2006. 294 p.

MATHEWSON, C.; FONT, R. G. Geologic environment: forgotten aspects in the land use planning process. The Geological Society of America U.S. A., engineering geology. Case histories, 1974. (10) p 23-28.

MENEZES, D. B.; ZUQUETTE, L. V. Avaliações metodológicas em estudos geoambientais de bacias hidrográficas: a Bacia do Rio Pardo. In: Simpósio Brasileiro de Cartografia Geotécnia E Geoambiental, 5., 2004, São Carlos. Anais... São Carlos: 2004. p. 291 - 300.

MEURER, F., VIEIRA, G. F. Plano Diretor para Municípios de Pequeno Porte: a experiência do plano diretor regional participativo da AMAVI. In: PPLA 2010: Seminário Política e Planejamento, 2, 2010. Curitiba. Anais... Curitiba: Ambiens, 2010. 
MICHAEL, F.; STEPHEN, D. PALLADINO.Geographic information systems as a tool in science and technology education. Speculations in Science and Technology, v. 18, p. 278$286,1995$.

MILANO, M. S. Unidades de conservação - técnica, lei e ética para a conservação da biodiversidade. In: Direito ambiental das áreas protegidas - o regime jurídico das unidades de conservação. Coord. Antônio Herman Benjamin. Rio de Janeiro: Forense Universitária, p. 341, 2001.

MILLER, V.C. A quantitative geomorphology study of drainage basin characteristic in the Clinch Mountain Area. New York: Virginia and Tennesse. Dept. of Geology. n. 3, p. 30, 1953.

\section{MINISTÉRIO DAS CIDADES. Plano Diretor Participativo - Guia para a elaboração pelos municípios e cidadãos. 160p. 2004.}

MINISTÉRIO DO MEIO AMBIENTE. Tabela consolidada das Unidades de Conservação. Disponível em: http://www.mma.gov.br/images/arquivo/80112/CNUC_Categoria_Fevereiro_2015.pdf. Acesso em: 14 de janeiro de 2016.

MOLLE, F. River-basin planning and management: The social life of a concept. Geoforum, Dublin, v. 40, p.484-494, 2009.

MOURA, C.A. de. Avaliação de Tendência a Enchentes das Bacias Hidrográficas do Município de Caraguatatuba (SP). Revista de Geografia, Recife, v. 30, n. 2, p.123-138, 2013.

MURUTHI, P. The Process of Preparing a General Management Plan for a Protected Area. AWF Working Papers. 12p. 2006.

NAG, S. K. Morphometric Analysis Using Remote Sensing Techniques in the Chaka Subbasin, Purulia District, West Bengal. Journal of The Indian Society of Remote Sensing, v. 26, n. 12, p.69-76, 1998.

NASCIMENTO, W. M. do; VILLAÇA, M. G. Bacias Hidrográficas: Planejamento e Gerenciamento. Revista Eletrônica da Associação dos Geógrafos Brasileiros, Três Lagoas, v. 5, n. 7, p.102-121, 2008.

NOVAIS, G. T. Caracterização Climática da Mesorregião do Triângulo Mineiro/Alto Parnaíba e do entorno da Serra da Canastra (MG). 2011. 124 f. Dissertação (Mestrado) Curso de Geografia, Universidade Federal de Uberlândia, Uberlândia, 2011.

NOVO, E. M. L. de M. Sensoriamento Remoto: Princípios e Aplicações. 2. ed. São Paulo: Edgard Blücher, 1992. 308 p.

OLIVEIRA, A. V. L. C. de. Zoneamento Geoambiental como Subsídio ao Planejamento Territorial Municipal: Estudo de Caso para Currais Novos/RN. 2012. 109 f. Dissertação (Mestrado) - Curso de Desenvolvimento e Meio Ambiente, Universidade Federal do Rio Grande do Norte, Natal, 2012. 
OLIVEIRA, H. L. de P. R.; SOARES, A. M.; NISHIYAMA, L. Técnicas de Geoprocessamento Aplicadas à Delimitação e Caracterização das Áreas de Preservação Permanente (APPs) dos Cursos D'água da Bacia Hidrográfica do Córrego Olhos D'água no Município de Uberlândia (MG) - Brasil. Revista Geográfica de América Central, Heredia, v. 47, n. 2, p.1-17, 2011.

OLIVEIRA, P. T. S. de et al. Zoneamento Ambiental aplicado à Conservação do Solo e da Água. Revista Brasileira de Ciência do Solo, Viçosa, n. 35, p.1723-1734, 2011.

OLIVEIRA, V. de P. S. de et al. A discussão da política ambiental no Plano Diretor de São João da Barra.Boletim do Observatório Ambiental Alberto Ribeiro Lamego, Campos dos Goytacazes, v. 1, n. 1, p.21-29, 2007.

PALOMO, I. et al. Limitations of Protected Areas Zoning in Mediterranean Cultural Landscapes Under the Ecosystem Services Approach. Ecosystems, v. 17, p.1202-1215, 2014.

PANIZZA, A. de C.; FONSECA, F. P. Técnicas de Interpretação Visual de Imagens.Geousp - Espaço e Tempo, São Paulo, n. 30, p.30-43, 2011.

PARKS AND WILDLIFE SERVICE. Draft Management Plan 2015: Narawntapu National Park, Hawley Nature Reserve. Hobart: 2015. 69 p.

PARKS VICTORIA AND DSE. Great Otway National Park and Otway Forest Park Management Plan. Melbourne: 2009. 106 p.

PELLIZZARO, P.C. et al. Gestão e Manejo de Áreas Naturais Protegidas: Contexto Internacional. Ambiente \& Sociedade, São Paulo, v. 18, n. 1, p.21-40, 2015.

PEJON, O. J. Mapeamento Geotécnico da Folha de Piracicaba-SP (Escala 1:100.000): Estudo de Aspectos Metodológicos, de Caracterização e de Apresentação dos Atributos. 1992. 1 v. Tese (Doutorado) - Curso de Geotecnia, Universidade de São Paulo, São Carlos, 1992.

PEREIRA, G. S. O Plano de Manejo e o seu Uso como Ferramenta de Gestão de Parques Nacionais no Estado do Rio de Janeiro. 2009. 102 f. Dissertação (Mestrado) - Curso de Ciências, Universidade Federal Rural do Rio de Janeiro, Seropédica, 2009.

PEREIRA, J. R. G. Um Estudo sobre alguns Métodos Hierárquicos para Análise de Agrupamentos. 1993. 147f. Dissertação (Mestrado) - Curso de Estatística, Instituto de Matemática, Estatística e Ciência da Computação, Universidade Estadual de Campinas, Campinas, 1993.

PERES, R. B.; SILVA, R. S. Interfaces da gestão ambiental urbana e gestão regional: análise da relação entre Planos Diretores Municipais e Planos de Bacia Hidrográfica. Revista Brasileira de Gestão Urbana, Curitiba, v. 5, n. 2, p.13-25, 2013.

PESSÔA, F. da S.; FAÇANHA, A. C. A bacia hidrográfica como unidade geossistêmica e territorial: em questão a Bacia do Parnaíba. Revista de Geociências do Nordeste, Caicó, v. 2, p.735-744, 2016. 
PESTANA, L. M. A Agenda Marrom: o planejamento urbano ambiental. Revista de Direito da Cidade, v. 1, n. 1, p.95-141, 2006.

PINTO, N. G. M.; LOPES, M. M.; CORONEL, D. A. Análise da Degradação Ambiental nos Municípios e Mesorregiões do Estado do Paraná. Revista Paranaense de

Desenvolvimento, Curitiba, v. 35, n. 126, p.191-206, 2014.

PINTO, V. G. et al. Influência do número de classes de vulnerabilidade na determinação da suscetibilidade morfométrica à inundação. Revista Ambiente e Água, Taubaté, v. 11, n. 3, p.637-649, 2016.

PIRES, J. S.R.; SANTOS, J. E. dos; DEL PRETTE, M. E. A utilização do conceito de bacia hidrográfica para a conservação dos recursos naturais. In: SCHIAVETTI, A.; CAMARGO, A. F. M.. Conceitos de Bacias Hidrográficas: Teorias e Aplicações. Ilhéus: Editus, 2002. Cap. 1. p. 17-35.

PULLEN, H. N.; PATTERSON, M. W. Applications and trends of remote sensing in professional urban planning. GeographyCompass. v. 5, n. 5, p. 249-261, 2011.

RATHER, M. A. et al. Assessing the influence of watershed characteristics on soil erosion susceptibility of Jhelum basin in Kashmir Himalayas. Arabian Journal Of Geosciences, v. 10, n. 3, p.1-25, 2017.

RICHARDSON, J.C. et al. Testing the applicability of morphometric characterisation in discordant catchments to ancient landscapes: A case study from southern Africa. Geomorphology, v. 261, p.162-176, 2016.

REZENDE, D. A.; ULTRAMARI, C. Plano diretor e planejamento estratégico municipal: introdução teórico-conceitual. Revista de Administração Pública, Rio de Janeiro, v. 41, n. 2, p.255-271, 2007.

ROCHA, S. P.; CRUZ, C. B. M. Aplicação do ITA na análise espaço-temporal do entorno da BR-101 nos municípios de Angra dos Reis e Parati. In: SIMPÓSIO BRASILEIRO DE SENSORIAMENTO REMOTO, 14., 2009, Natal. Simpósio. Natal: INPE, 2009. p. 1505 1512.

ROCHA, M. B. B.; SEER, H. J. Mapeamento e caracterização do meio físico de Araxá - MG, utilizando técnicas de geoprocessamento. Educação e Tecnologia. Belo Horizonte, v. 13, n. 1, p.03-13, 2008.

RODRIGUES, P. M. S. et al. Solos, relevo e vegetação determinam os geoambientes de unidade de conservação do norte de Minas Gerais, Brasil. Neotropical

BiologyAndConservation, São Leopoldo, v. 10, n. 1, p.31-42, 2015.

RODRIGUES, V. L. Mapeamento Geotécnico como base para o Planejamento Urbano e Ambiental: Município de Jaú/SP. 2008. 154 f. Dissertação (Mestrado) - Curso de Geotecnia, Departamento de Geotecnia, Universidade de São Paulo, São Carlos, 2008. Análise da Legislação Ambiental no Município de São Sebastião (SP). 2005. 201 f. 
Dissertação (Mestrado) - Curso de Geografia, Departamento de Geografia, Universidade de São Paulo, São Paulo, 2005.

SÁNCHEZ, L. E. Avaliação de Impacto Ambiental: Conceitos e Métodos. 2. ed. São Paulo: Oficina de Textos, 2013. $584 \mathrm{p}$.

SANTOS, A. A. Parques Nacionais Brasileiros: relação entre Planos de Manejo e a atividade ecoturística. Revista Brasileira de Ecoturismo, São Paulo, v. 4, n. 1, p.141-162, 2011.

SANTOS, A. de P. dos. Delimitação de Área de Preservação Permanente (APP) de Topo de Morros. Curso de Engenharia de Agrimensura e Cartografia. 34p. Viçosa, 2013.

SANTOS, B. M. dos et al. Zoneamento das Unidades Ambientais, Cenários e Diretrizes Gerais e Específicas: Potencial à Produção Rural. In: COLLARES, E. G. Zoneamento Ambiental das Sub-Bacias Hidrográficas dos Afluentes Mineiros do Médio Rio Grande. Passos: Edifesp, 2013. Cap. 6. v.4. p. 68-80.

SANTOS, B. M. dos; COLLARES, A. C. Z. B.; COLLARES, E. G. Zoneamento das Unidades Ambientais, Cenários e Diretrizes Gerais e Específicas: Suscetibilidade à Inundação. In: COLLARES, E. G. Zoneamento Ambiental das Sub-Bacias Hidrográficas dos Afluentes Mineiros do Médio Rio Grande. Passos: Edifesp, 2013. Cap. 2. v.4. p. 50-63.

SANTOS, C. A. dos; SOBREIRA, F. G. Análise morfométrica como subsídio ao zoneamento territorial: o caso das bacias do Córrego Carioca, Córrego do Bação e Ribeirão Carioca na região do Alto Rio das Velhas-MG. Rem - Revista Escola de Minas, Ouro Preto, v. 1, n. 61, p.77-85, 2008.

SARMA, P. K. et al. Geospatial study on morphometric characterization of Umtrew River basin of Meghalaya, India. International Journal of Water Resources and Environmental Engineering, v.5, n. 8, p.489-498, 2013.

SCCOTI, A. A. V. Zoneamento Geoambiental da Bacia Hidrográfica do Rio Ibicuí da Armada - RS: Potencialidades e Suscetibilidade. 2015. 151 f. Tese (Doutorado) - Curso de Geografia, Universidade Federal de Santa Maria, Santa Maria, 2015.

SCHIRMER, G. J. Mapeamento Geoambiental dos Municípios de Agudo, Dona Francisca, Faxinal do Soturno, Nova Palma e Pinhal Grande - RS. 2012. 155 f. Dissertação (Mestrado) - Curso de Geografia, Universidade Federal de Santa Maria, Santa Maria, 2012.

SCHUMM, S. A. Evolution of Drainage Systems and Slopes in Badlands at Perth Amboy, New Jersey. Bulletin of The Geological Society of America, v. 67, p.597-646, 1956.

SCOLFORO, J.R,; OLIVEIRA, A.D.; CARVALHO, L M. T. 2016. Inventário Florestal de Minas Gerais. Disponível em:

<http://geosisemanet.meioambiente.mg.gov.br/inventarioFlorestal/>. Acesso em: $18 \mathrm{dez}$. 2016. 
SIKORSKA-MAYKOWSKA, M.; STRZELECKI, R.; LEWANDOWSKI, P.

Geoenvironmental Map of Poland, 1 : 50.000 scale. Przeglad Geologiczny, v. 53, p.986-987, 2005.

SILVA, C. R. da; DANTAS, M. E. Mapas Geoambientais. In: Simpósio Brasileiro de Cartografia, 7., 2010, Maringá. Simpósio. Maringá: 2010. p. 1 - 17.

SILVA, J. X. da. Geomorfologia, Análise Ambiental e Geoprocessamento. Revista Brasileira de Geomorfologia, São Paulo, v. 1, n. 1, p.48-58, 2000.

SILVA, V. C. B.; MACHADO, P. de S. Integração da Geomorfologia e do Geoprocessamento para a Compartimentação do Relevo da República do Panamá. Revista Escientia, Belo Horizonte, v. 5, n. 2, p.07-23, 2012.

SILVA, V. R. Análise Sócio-Ambiental da Bacia do Rio Biguaçu-SC: Subsídios ao Planejamento e Ordenamento Territorial. 2007. 209 f. Tese (Doutorado) - Curso de Geografia Física, Departamento de Geografia, Universidade de São Paulo, São Paulo, 2007.

SILVA NETO, A. F. da et al. Geotecnologias para a caracterização morfométrica de bacia hidrográfica. In: SIMPÓSIO BRASILEIRO DE SENSORIAMENTO REMOTO, 16., 2013, Foz do Iguaçu. Anais... . Foz do Iguaçu: Inpe, 2013. p. 5483 - 5490.

SILVA NETO, J. C. A. da. Zoneamento Ambiental como Subsídio para o Ordenamento do Território da Bacia Hidrográfica do Rio Salobra, Serra da Bodoquena - MS. 2013. 291 f. Tese (Doutorado) - Curso de Geografia, Universidade Estadual Paulista "Júlio Mesquita Filho", Presidente Prudente, 2013.

SILVEIRA, C. T. da et al. Emprego de Atributos Topográficos no Mapeamento da Susceptibilidade a Processos Geoambientais na Bacia do Rio Jacareí, Paraná. Sociedade \& Natureza, Uberlândia, v. 3, n. 25, p.623-639, 2013.

SINGH, P.; THAKUR, J. K.; SINGH, U. C. Morphometric analysis of Morar River Basin, Madhya Pradesh, India, using remote sensing and GIS techniques. Environmental Earth Sciences, v. 68, n. 7, p.1967-1977, 2013.

SIQUEIRA, F. B. Análise Comparativa dos Instrumentos de Gestão de Áreas Protegidas e Recursos Hídricos do Brasil e da Austrália. 2017. 231 f. Dissertação (Mestrado) - Curso de Ciências em Engenharia de Energia, Engenharia de Energia, Universidade Federal de Itajubá, Itajubá, 2017.

SONI, S. Assessment of morphometric characteristics of Chakrar watershed in Madhya Pradesh India using geospatial technique. Applied Water Science, p.1-14, 2016.

SOUSA, S. K. J. de. Geologia e aspectos geoturísticos do município de Delfinópolis/MG. 2001. 91 f. Dissertação (Mestrado) - Curso de Geociências, Instituto de Geociências e Ciências Exatas, Universidade Estadual Paulista, Rio Claro, 2001.

SPIRONELLO, R. L. Zoneamento Antrópico - Ambiental do Município de Iporã do Oeste-SC: Contribuição para a Reflexão e Tomada de Decisões no Âmbito das 
Microbacias Hidrográficas. 2007. 161 f. Tese (Doutorado) - Curso de Geografia Humana, Departamento de Geografia,Universidade de São Paulo, São Paulo, 2007.

STEFFEN, C. A.; MORAES, E. C.; GAMA, F. F. Radiometria Óptica Espectral - Tutorial. In: VIII Simpósio Brasileiro de Sensoriamento Remoto,1996, Salvador. Anais... Salvador: INPE, 1996.

STRAHLER, A. N. Quantitative analysis of watershed geomorphology. New Halen: Transacion. American Geophysical Union, 1957. v38. p. 913-920.

TEODORO, V. L. I. et al. O conceito de bacia hidrográfica e a importância da caracterização morfométrica para o entendimento da dinâmica ambiental local. Revista Uniara, Araraquara, n. 20, p.137-156, 2007.

THOMAS, B. L. et al. Zoneamento Ambiental como Subsídio à Elaboração do Plano de Manejo da Reserva Particular do Patrimônio Natural da Fundação MO'Ã em Itaara (RS). Revista Geografia, Londrina, p.125-142, 2011.

THOMAS, B. L. Proposta de Zoneamento Ambiental para o município de Arroio do Meio RS. Ra'e Ga, Curitiba, n. 24, p.199-226, 2012.

TRAJANO, S. R. R. da S. et. al. Análise Morfométrica de Bacia Hidrográfica - Subsídio à Gestão Territorial Estudo de caso no Alto e Médio Mamanguape. Embrapa Gestão Territorial, 1ed., Campinas, 2012.

TRENTIN, R.; ROBAINA, L. E.deS. Metodologia para Mapeamento Geoambiental no Oeste do Rio Grande do Sul. In: Simpósio Brasileiro de Geografia Física Aplicada, 11., 2005, São Paulo. Anais... São Paulo: 2005. p. 3606 - 3615.

ULTRAMARI, C.; REZENDE, D. A. Planejamento Estratégico e Planos Diretores Municipais: Referenciais e Bases de Aplicação. Rac, Curitiba, v. 12, n. 3, p.717-739, 2008.

VEDOVELLO, R.; MATTOS, J. T. de. Zoneamento Geotécnico, por Sensoriamento Remoto, para Estudos de Planejamento do Meio Físico - Aplicação em Expansão Urbana. In: SIMPÓSIO BRASILEIRO DE SENSORIAMENTO REMOTO, 7., 1993, Curitiba. Simpósio. Curitiba: INPE, 1993. p. 155 - 162.

VESTENA, L. R.; CHECCHIA, T.; KOBYIAMA, M. Análise Morfométrica e Geomorfológica da Bacia Hidrográfica do Caeté, Alfredo Wagner/SC. Boletim de Geografia, Maringá, v. 29, n. 2, p.93-106, 2011.

WWF. Unidades de Conservação. Disponível em:<www.wwf.org.br/natureza_brasileira/questoes_ambientais/unid/>. Acesso em: $29 \mathrm{de}$ março de 2017.

ZAIKANOV, V. G.; MINAKOVA, T. B.; BULDAKOVA, E. V. Approaches to Regional Geoenvironmental Mapping. Water Resources, v. 41, n. 7, p.560-572, 2014.

Principles of GIS Support of Geoenvironmental Mapping at a Regional

Level. Water Resources, v. 42, n. 7, p.970-974, 2015. 
ZAINE, J. E. Mapeamento Geológico-Geotécnico por Meio do Método do Detalhamento Progressivo: Ensaio de Aplicação na Área Urbana do Município de Rio Claro

(SP). 2000. 149 f. Tese (Doutorado) - Curso de Geociências, Pós-Graduação em Geociências, Universidade Estadual Paulista, Rio Claro, 2000.

ZANON, B. et al. Il Parco Naturale Paneveggio - Pale di San Martino e la revisione del Piano. Trento: 2016. 178 p.

ZUQUETTE, L. V. Análise Crítica da Cartografia Geotécnica e Proposta Metodológica para Condições Brasileiras. 1987. v.1. Tese (Doutorado) - Curso de Geotecnia, Universidade de São Paulo, São Carlos, 1987.

L. V. Importância do mapeamento geotécnico no uso e ocupação do meio físico: fundamentos e guia para elaboração. Tese (Livre Docência) São Carlos - Escola de Engenharia de São Carlos, Universidade de São Paulo - USP. 1993.

L. V.; NAKAZAWA, V. A. Cartas de Geologia de Engenharia. In: ABGE. Geologia de Engenharia. São Paulo, 1998. p. 283-300. 

APÊNDICE 

APÊNDICE A - Percentual de área dos atributos do meio físico das bacias hidrográficas de $1^{\mathrm{a}}$ ordem antes da $\mathbf{1}^{\mathrm{a}}$ análise de agrupamentos

\begin{tabular}{|c|c|c|c|c|c|c|c|c|}
\hline \multicolumn{9}{|c|}{ Materiais Inconsolidados (apenas aspecto textural) (\%) } \\
\hline $\begin{array}{c}\text { Bacias } \\
\text { Hidrográficas }\end{array}$ & $\begin{array}{l}\text { Área } \\
\left(\mathrm{km}^{2}\right)\end{array}$ & Areia & Silte & Silte e Rocha & $\begin{array}{l}\text { Distribuída } \\
\text { (Areia) }\end{array}$ & $\begin{array}{l}\text { Distribuída } \\
\text { (Silte) }\end{array}$ & $\begin{array}{c}\text { Distribuída } \\
\text { (Silte/Argila) }\end{array}$ & $\begin{array}{c}\text { Distribuída } \\
\text { (Argila/Silte/Areia) }\end{array}$ \\
\hline BH 1_1 & 1,05 & 0,00 & 0,00 & 0,00 & 0,00 & 41,58 & 58,42 & 0,00 \\
\hline BH 1_2 & 3,29 & 1,16 & 30,10 & 0,00 & 0,00 & 19,85 & 28,31 & 20,58 \\
\hline BH 1_3 & 0,89 & 100,00 & 0,00 & 0,00 & 0,00 & 0,00 & 0,00 & 0,00 \\
\hline BH 1_4 & 0,44 & 6,32 & 93,68 & 0,00 & 0,00 & 0,00 & 0,00 & 0,00 \\
\hline BH 1_5 & 0,93 & 67,50 & 32,50 & 0,00 & 0,00 & 0,00 & 0,00 & 0,00 \\
\hline BH 1_6 & 0,93 & 0,00 & 46,20 & 53,80 & 0,00 & 0,00 & 0,00 & 0,00 \\
\hline BH 1_7 & 2,12 & 5,21 & 94,77 & 0,02 & 0,00 & 0,00 & 0,00 & 0,00 \\
\hline BH 1_8 & 2,82 & 80,37 & 19,63 & 0,00 & 0,00 & 0,00 & 0,00 & 0,00 \\
\hline BH 1_9 & 2,34 & 33,61 & 66,39 & 0,00 & 0,00 & 0,00 & 0,00 & 0,00 \\
\hline BH 1_10 & 0,71 & 69,57 & 30,43 & 0,00 & 0,00 & 0,00 & 0,00 & 0,00 \\
\hline BH 1_11 & 0,37 & 73,83 & 26,17 & 0,00 & 0,00 & 0,00 & 0,00 & 0,00 \\
\hline BH 1_12 & 2,85 & 18,29 & 81,71 & 0,00 & 0,00 & 0,00 & 0,00 & 0,00 \\
\hline BH 1_13 & 1,54 & 87,09 & 12,91 & 0,00 & 0,00 & 0,00 & 0,00 & 0,00 \\
\hline BH 1_14 & 1,05 & 22,94 & 77,06 & 0,00 & 0,00 & 0,00 & 0,00 & 0,00 \\
\hline BH 1_15 & 2,09 & 92,64 & 7,36 & 0,00 & 0,00 & 0,00 & 0,00 & 0,00 \\
\hline BH 1_16 & 0,34 & 89,43 & 10,57 & 0,00 & 0,00 & 0,00 & 0,00 & 0,00 \\
\hline BH 1_17 & 1,29 & 48,76 & 51,24 & 0,00 & 0,00 & 0,00 & 0,00 & 0,00 \\
\hline BH 1_18 & 1,69 & 31,22 & 45,28 & 23,50 & 0,00 & 0,00 & 0,00 & 0,00 \\
\hline BH 1_19 & 1,48 & 79,91 & 14,28 & 0,00 & 0,00 & 0,00 & 5,81 & 0,00 \\
\hline BH 1_20 & 1,74 & 25,85 & 54,60 & 0,00 & 0,00 & 0,00 & 19,55 & 0,00 \\
\hline BH 1_21 & 0,34 & 58,61 & 40,31 & 0,00 & 0,00 & 0,00 & 1,08 & 0,00 \\
\hline BH 1_22 & 0,62 & 11,23 & 43,53 & 18,04 & 0,00 & 0,00 & 27,20 & 0,00 \\
\hline BH 1_23 & 0,90 & 12,58 & 49,94 & 0,00 & 0,00 & 0,00 & 37,48 & 0,00 \\
\hline BH 1_24 & 1,09 & 0,00 & 36,94 & 0,00 & 0,00 & 0,00 & 63,06 & 0,00 \\
\hline BH 1_25 & 3,57 & 1,91 & 38,04 & 34,92 & 0,00 & 0,00 & 25,13 & 0,00 \\
\hline BH 1_26 & 0,53 & 19,73 & 80,23 & 0,00 & 0,00 & 0,00 & 0,04 & 0,00 \\
\hline
\end{tabular}




\begin{tabular}{|c|c|c|c|c|c|c|c|c|}
\hline \multicolumn{9}{|c|}{ Materiais Inconsolidados (apenas aspecto textural) (\%) } \\
\hline $\begin{array}{c}\text { Bacias } \\
\text { Hidrográficas }\end{array}$ & $\begin{array}{l}\text { Área } \\
\left(\mathrm{km}^{2}\right)\end{array}$ & Areia & Silte & Silte e Rocha & $\begin{array}{l}\text { Distribuída } \\
\text { (Areia) }\end{array}$ & $\begin{array}{l}\text { Distribuída } \\
\text { (Silte) }\end{array}$ & $\begin{array}{c}\text { Distribuída } \\
\text { (Silte/Argila) }\end{array}$ & $\begin{array}{c}\text { Distribuída } \\
\text { (Argila/Silte/Areia) }\end{array}$ \\
\hline BH 1_27 & 0,56 & 0,00 & 88,47 & 0,00 & 0,00 & 0,00 & 11,53 & 0,00 \\
\hline BH 1_28 & 1,45 & 1,17 & 98,83 & 0,00 & 0,00 & 0,00 & 0,00 & 0,00 \\
\hline BH 1_29 & 1,00 & 23,11 & 76,89 & 0,00 & 0,00 & 0,00 & 0,00 & 0,00 \\
\hline BH 1_30 & 0,80 & 14,86 & 85,14 & 0,00 & 0,00 & 0,00 & 0,00 & 0,00 \\
\hline BH 1_31 & 1,09 & 4,72 & 95,28 & 0,00 & 0,00 & 0,00 & 0,00 & 0,00 \\
\hline BH 1_32 & 0,65 & 15,99 & 84,01 & 0,00 & 0,00 & 0,00 & 0,00 & 0,00 \\
\hline BH 1_33 & 0,27 & 0,00 & 100,00 & 0,00 & 0,00 & 0,00 & 0,00 & 0,00 \\
\hline BH 1_34 & 1,03 & 0,04 & 99,96 & 0,00 & 0,00 & 0,00 & 0,00 & 0,00 \\
\hline BH 1_35 & 0,37 & 0,00 & 100,00 & 0,00 & 0,00 & 0,00 & 0,00 & 0,00 \\
\hline BH 1_36 & 1,19 & 0,00 & 96,37 & 3,63 & 0,00 & 0,00 & 0,00 & 0,00 \\
\hline BH 1_37 & 0,17 & 4,38 & 86,83 & 8,79 & 0,00 & 0,00 & 0,00 & 0,00 \\
\hline BH 1_38 & 0,63 & 0,00 & 98,99 & 1,01 & 0,00 & 0,00 & 0,00 & 0,00 \\
\hline BH 1_39 & 1,06 & 29,26 & 57,84 & 12,90 & 0,00 & 0,00 & 0,00 & 0,00 \\
\hline BH 1_40 & 0,32 & 0,00 & 100,00 & 0,00 & 0,00 & 0,00 & 0,00 & 0,00 \\
\hline BH 1_41 & 0,71 & 28,40 & 57,79 & 13,81 & 0,00 & 0,00 & 0,00 & 0,00 \\
\hline BH 1_42 & 0,47 & 0,00 & 100,00 & 0,00 & 0,00 & 0,00 & 0,00 & 0,00 \\
\hline BH 1_43 & 0,20 & 6,99 & 60,97 & 32,04 & 0,00 & 0,00 & 0,00 & 0,00 \\
\hline BH 1_44 & 1,32 & 53,87 & 0,00 & 0,00 & 38,81 & 0,00 & 7,32 & 0,00 \\
\hline BH 1_45 & 0,73 & 0,00 & 61,86 & 0,00 & 0,00 & 0,00 & 38,14 & 0,00 \\
\hline BH 1_46 & 1,74 & 0,00 & 93,68 & 0,00 & 0,00 & 0,00 & 6,32 & 0,00 \\
\hline BH 1_47 & 0,30 & 0,00 & 69,53 & 0,00 & 0,00 & 0,00 & 30,47 & 0,00 \\
\hline BH 1_48 & 2,19 & 0,00 & 86,63 & 0,00 & 0,00 & 0,00 & 13,37 & 0,00 \\
\hline BH 1_49 & 0,72 & 0,00 & 80,37 & 0,00 & 0,00 & 0,00 & 19,63 & 0,00 \\
\hline BH 1_50 & 1,16 & 0,87 & 85,53 & 0,00 & 0,00 & 0,00 & 7,74 & 5,86 \\
\hline BH 1_51 & 1,04 & 15,34 & 62,93 & 0,00 & 0,00 & 0,00 & 21,73 & 0,00 \\
\hline BH 1_52 & 1,56 & 0,61 & 98,33 & 0,00 & 0,00 & 0,00 & 0,96 & 0,10 \\
\hline
\end{tabular}




\begin{tabular}{|c|c|c|c|c|c|c|c|c|}
\hline \multicolumn{9}{|c|}{ Materiais Inconsolidados (apenas aspecto textural) (\%) } \\
\hline \begin{tabular}{c|} 
Bacias \\
Hidrográficas
\end{tabular} & $\begin{array}{l}\text { Área } \\
\left(\mathrm{km}^{2}\right)\end{array}$ & Areia & Silte & Silte e Rocha & $\begin{array}{l}\text { Distribuída } \\
\text { (Areia) }\end{array}$ & $\begin{array}{l}\text { Distribuída } \\
\text { (Silte) }\end{array}$ & $\begin{array}{l}\text { Distribuída } \\
\text { (Silte/Argila) }\end{array}$ & $\begin{array}{c}\text { Distribuída } \\
\text { (Argila/Silte/Areia) }\end{array}$ \\
\hline BH 1_53 & 1,27 & 0,00 & 0,00 & 0,00 & 100,00 & 0,00 & 0,00 & 0,00 \\
\hline BH 1_54 & 0,86 & 0,00 & 0,00 & 0,00 & 100,00 & 0,00 & 0,00 & 0,00 \\
\hline BH 1_55 & 0,13 & 0,00 & 0,00 & 0,00 & 100,00 & 0,00 & 0,00 & 0,00 \\
\hline BH 1_56 & 1,92 & 0,00 & 0,00 & 0,00 & 100,00 & 0,00 & 0,00 & 0,00 \\
\hline BH 1_57 & 2,56 & 0,00 & 0,00 & 0,00 & 100,00 & 0,00 & 0,00 & 0,00 \\
\hline BH 1_58 & 0,39 & 0,00 & 0,00 & 0,00 & 100,00 & 0,00 & 0,00 & 0,00 \\
\hline BH 1_59 & 0,81 & 0,00 & 0,00 & 0,00 & 100,00 & 0,00 & 0,00 & 0,00 \\
\hline BH 1_60 & 0,61 & 0,00 & 0,00 & 0,00 & 100,00 & 0,00 & 0,00 & 0,00 \\
\hline BH 1_61 & 1,31 & 0,00 & 0,00 & 0,00 & 100,00 & 0,00 & 0,00 & 0,00 \\
\hline BH 1_62 & 0,62 & 0,00 & 0,00 & 0,00 & 100,00 & 0,00 & 0,00 & 0,00 \\
\hline BH 1_63 & 0,52 & 0,00 & 0,00 & 0,00 & 100,00 & 0,00 & 0,00 & 0,00 \\
\hline BH 1_64 & 2,86 & 0,00 & 0,00 & 0,00 & 88,00 & 0,00 & 12,00 & 0,00 \\
\hline BH 1_65 & 15,38 & 0,00 & 0,00 & 0,00 & 74,63 & 0,00 & 1,40 & 23,97 \\
\hline BH 1_66 & 5,56 & 0,00 & 0,00 & 0,00 & 100,00 & 0,00 & 0,00 & 0,00 \\
\hline BH 1_67 & 1,35 & 0,00 & 0,00 & 0,00 & 97,27 & 0,00 & 2,73 & 0,00 \\
\hline BH 1_68 & 17,12 & 0,00 & 0,00 & 0,00 & 100,00 & 0,00 & 0,00 & 0,00 \\
\hline BH 1_69 & 10,66 & 0,00 & 0,00 & 0,00 & 100,00 & 0,00 & 0,00 & 0,00 \\
\hline BH 1_70 & 4,63 & 0,00 & 0,00 & 0,00 & 100,00 & 0,00 & 0,00 & 0,00 \\
\hline BH 1_71 & 1,40 & 58,71 & 41,29 & 0,00 & 0,00 & 0,00 & 0,00 & 0,00 \\
\hline BH 1_72 & 3,69 & 99,19 & 0,81 & 0,00 & 0,00 & 0,00 & 0,00 & 0,00 \\
\hline BH 1_73 & 3,93 & 26,89 & 0,00 & 0,00 & 73,11 & 0,00 & 0,00 & 0,00 \\
\hline BH 1_74 & 0,64 & 0,00 & 0,00 & 0,00 & 100,00 & 0,00 & 0,00 & 0,00 \\
\hline BH 1_75 & 15,77 & 0,00 & 0,00 & 0,00 & 100,00 & 0,00 & 0,00 & 0,00 \\
\hline BH 1_76 & 21,68 & 0,18 & 0,00 & 0,00 & 85,78 & 0,00 & 0,00 & 14,04 \\
\hline BH 1_77 & 0,77 & 0,06 & 0,00 & 0,00 & 99,94 & 0,00 & 0,00 & 0,00 \\
\hline BH 1_78 & 0,73 & 100,00 & 0,00 & 0,00 & 0,00 & 0,00 & 0,00 & 0,00 \\
\hline
\end{tabular}




\begin{tabular}{c|c|c|c|c|c|c|c|c}
\hline \multicolumn{7}{c}{ Materiais Inconsolidados (apenas aspecto textural) (\%) } \\
\hline $\begin{array}{c}\text { Bacias } \\
\text { Hidrográficas }\end{array}$ & $\begin{array}{c}\text { Área } \\
\left(\mathrm{km}^{2}\right)\end{array}$ & Areia & Silte & Silte e Rocha & $\begin{array}{c}\text { Distribuída } \\
\text { (Areia) }\end{array}$ & $\begin{array}{c}\text { Distribuída } \\
\text { (Silte) }\end{array}$ & $\begin{array}{c}\text { Distribuída } \\
(\text { Silte/Argila) }\end{array}$ & $\begin{array}{c}\text { Distribuída } \\
\text { (Argila/Silte/Areia) }\end{array}$ \\
\hline BH 1_79 & 0,23 & 100,00 & 0,00 & 0,00 & 0,00 & 0,00 & 0,00 & 0,00 \\
\hline BH 1_80 & 2,04 & 26,10 & 38,00 & 0,00 & 0,00 & 0,00 & 18,98 & 16,92 \\
\hline BH 1_81 & 2,45 & 0,00 & 0,00 & 0,00 & 100,00 & 0,00 & 0,00 & 0,00 \\
\hline BH 1_82 & 7,90 & 0,00 & 0,00 & 0,00 & 100,00 & 0,00 & 0,00 & 0,00 \\
\hline BH 1_83 & 13,75 & 0,00 & 0,00 & 0,00 & 100,00 & 0,00 & 0,00 & 0,00 \\
\hline BH 1_84 & 0,56 & 0,00 & 0,00 & 0,00 & 86,31 & 0,00 & 13,69 & 0,00 \\
\hline BH 1_85 & 10,84 & 0,00 & 0,00 & 0,00 & 100,00 & 0,00 & 0,00 & 0,00 \\
\hline
\end{tabular}




\begin{tabular}{|c|c|c|c|c|c|c|c|}
\hline \multicolumn{8}{|c|}{ Substrato Rochoso (\%) } \\
\hline $\begin{array}{c}\text { Bacias } \\
\text { Hidrográficas }\end{array}$ & Área $\left(\mathrm{km}^{2}\right)$ & Coberturas Quaternárias & Gnaisse & Xisto & Quartzito & Milonito & Xisto/Quartzito \\
\hline BH 1_1 & 1,05 & 0,00 & 100,00 & 0,00 & 0,00 & 0,00 & 0,00 \\
\hline BH 1_2 & 3,29 & 0,00 & 62,40 & 0,00 & 0,71 & 0,00 & 36,89 \\
\hline BH 1_3 & 0,89 & 11,39 & 0,00 & 0,00 & 88,61 & 0,00 & 0,00 \\
\hline BH 1_4 & 0,44 & 0,00 & 0,00 & 0,00 & 7,22 & 0,00 & 92,78 \\
\hline BH 1_5 & 0,93 & 0,00 & 0,00 & 0,00 & 67,50 & 0,00 & 32,50 \\
\hline BH 1_6 & 0,93 & 0,00 & 0,00 & 96,02 & 0,00 & 0,00 & 3,98 \\
\hline BH 1_7 & 2,12 & 0,00 & 0,00 & 81,70 & 12,10 & 6,20 & 0,00 \\
\hline BH 1_8 & 2,82 & 0,00 & 0,00 & 13,48 & 72,95 & 13,57 & 0,00 \\
\hline BH 1_9 & 2,34 & 0,00 & 0,00 & 2,66 & 40,06 & 57,28 & 0,00 \\
\hline BH 1_10 & 0,71 & 0,00 & 0,00 & 45,04 & 54,58 & 0,38 & 0,00 \\
\hline BH 1_11 & 0,37 & 0,00 & 0,00 & 51,02 & 48,98 & 0,00 & 0,00 \\
\hline BH 1_12 & 2,85 & 0,00 & 0,00 & 14,14 & 24,75 & 61,11 & 0,00 \\
\hline BH 1_13 & 1,54 & 0,00 & 0,00 & 8,35 & 91,65 & 0,00 & 0,00 \\
\hline BH 1_14 & 1,05 & 0,00 & 0,00 & 38,86 & 22,07 & 39,07 & 0,00 \\
\hline BH 1_15 & 2,09 & 0,00 & 0,00 & 5,58 & 94,42 & 0,00 & 0,00 \\
\hline BH 1_16 & 0,34 & 0,00 & 0,00 & 34,38 & 65,62 & 0,00 & 0,00 \\
\hline BH 1_17 & 1,29 & 27,27 & 0,00 & 51,26 & 21,47 & 0,00 & 0,00 \\
\hline BH 1_18 & 1,69 & 8,33 & 0,00 & 66,78 & 24,89 & 0,00 & 0,00 \\
\hline BH 1_19 & 1,48 & 22,89 & 0,00 & 10,93 & 48,21 & 17,97 & 0,00 \\
\hline BH 1_20 & 1,74 & 23,54 & 0,00 & 7,58 & 24,55 & 44,33 & 0,00 \\
\hline BH 1_21 & 0,34 & 4,67 & 0,00 & 36,72 & 58,61 & 0,00 & 0,00 \\
\hline BH 1_22 & 0,62 & 25,54 & 0,00 & 18,04 & 0,00 & 56,42 & 0,00 \\
\hline BH 1_23 & 0,90 & 58,98 & 0,00 & 28,52 & 8,96 & 3,54 & 0,00 \\
\hline BH 1_24 & 1,09 & 61,10 & 0,00 & 0,00 & 0,00 & 38,90 & 0,00 \\
\hline BH 1_25 & 3,57 & 31,46 & 0,00 & 20,31 & 1,90 & 46,33 & 0,00 \\
\hline BH 1_26 & 0,53 & 13,09 & 0,00 & 67,18 & 19,73 & 0,00 & 0,00 \\
\hline
\end{tabular}




\begin{tabular}{|c|c|c|c|c|c|c|c|}
\hline \multicolumn{8}{|c|}{ Substrato Rochoso (\%) } \\
\hline $\begin{array}{c}\text { Bacias } \\
\text { Hidrográficas }\end{array}$ & Área $\left(\mathrm{km}^{2}\right)$ & Coberturas Quaternárias & Gnaisse & Xisto & Quartzito & Milonito & Xisto/Quartzito \\
\hline BH 1_27 & 0,56 & 5,52 & 0,00 & 40,72 & 0,00 & 53,76 & 0,00 \\
\hline BH 1_28 & 1,45 & 0,00 & 0,00 & 0,00 & 1,17 & 98,83 & 0,00 \\
\hline BH 1_29 & 1,00 & 0,00 & 0,00 & 72,39 & 23,11 & 4,50 & 0,00 \\
\hline BH 1_30 & 0,80 & 0,00 & 0,00 & 0,00 & 14,87 & 61,85 & 23,28 \\
\hline BH 1_31 & 1,09 & 0,00 & 0,00 & 0,67 & 4,72 & 86,83 & 7,78 \\
\hline BH 1_32 & 0,65 & 0,00 & 0,00 & 0,00 & 15,99 & 69,88 & 14,13 \\
\hline BH 1_33 & 0,27 & 0,00 & 0,00 & 0,00 & 0,00 & 99,58 & 0,42 \\
\hline BH 1_34 & 1,03 & 0,00 & 0,00 & 0,68 & 0,04 & 93,78 & 5,50 \\
\hline BH 1_35 & 0,37 & 0,00 & 0,00 & 4,86 & 0,00 & 95,14 & 0,00 \\
\hline BH 1_36 & 1,19 & 0,00 & 0,00 & 4,56 & 0,00 & 91,81 & 3,63 \\
\hline BH 1_37 & 0,17 & 0,00 & 0,00 & 84,73 & 4,38 & 10,89 & 0,00 \\
\hline BH 1_38 & 0,63 & 0,00 & 0,00 & 0,00 & 0,00 & 98,99 & 1,01 \\
\hline BH 1_39 & 1,06 & 0,00 & 0,00 & 60,33 & 29,25 & 10,42 & 0,00 \\
\hline BH 1_40 & 0,32 & 0,00 & 0,00 & 0,00 & 0,00 & 100,00 & 0,00 \\
\hline BH 1_41 & 0,71 & 0,00 & 0,00 & 46,99 & 28,40 & 24,61 & 0,00 \\
\hline BH 1_42 & 0,47 & 0,00 & 0,00 & 0,00 & 0,00 & 100,00 & 0,00 \\
\hline BH 1_43 & 0,20 & 0,00 & 0,00 & 70,35 & 6,98 & 22,67 & 0,00 \\
\hline BH 1_44 & 1,32 & 0,00 & 0,14 & 0,00 & 0,00 & 0,00 & 99,86 \\
\hline BH 1_45 & 0,73 & 0,00 & 0,00 & 0,00 & 0,00 & 100,00 & 0,00 \\
\hline BH 1_46 & 1,74 & 0,00 & 0,00 & 0,00 & 0,00 & 100,00 & 0,00 \\
\hline BH 1_47 & 0,30 & 42,19 & 0,00 & 28,98 & 0,00 & 28,83 & 0,00 \\
\hline BH 1_48 & 2,19 & 32,45 & 0,00 & 40,12 & 0,00 & 27,43 & 0,00 \\
\hline BH 1_49 & 0,72 & 19,92 & 0,00 & 0,00 & 0,00 & 80,08 & 0,00 \\
\hline BH 1_50 & 1,16 & 0,00 & 0,00 & 93,27 & 0,87 & 0,00 & 5,86 \\
\hline BH 1_51 & 1,04 & 0,00 & 0,00 & 84,52 & 15,48 & 0,00 & 0,00 \\
\hline BH 1_52 & 1,56 & 0,00 & 0,00 & 99,29 & 0,61 & 0,00 & 0,10 \\
\hline
\end{tabular}




\begin{tabular}{|c|c|c|c|c|c|c|c|}
\hline \multicolumn{8}{|c|}{ Substrato Rochoso (\%) } \\
\hline $\begin{array}{c}\text { Bacias } \\
\text { Hidrográficas }\end{array}$ & Área $\left(\mathrm{km}^{2}\right)$ & Coberturas Quaternárias & Gnaisse & Xisto & Quartzito & Milonito & Xisto/Quartzito \\
\hline BH 1_53 & 1,27 & 0,00 & 0,00 & 0,00 & 0,00 & 0,00 & 100,00 \\
\hline BH 1_54 & 0,86 & 0,00 & 0,00 & 0,00 & 0,00 & 0,00 & 100,00 \\
\hline BH 1_55 & 0,13 & 0,00 & 0,00 & 0,00 & 0,00 & 0,00 & 100,00 \\
\hline BH 1_56 & 1,92 & 0,00 & 0,00 & 0,00 & 0,00 & 0,00 & 100,00 \\
\hline BH 1_57 & 2,56 & 0,00 & 0,10 & 0,00 & 0,00 & 0,00 & 99,90 \\
\hline BH 1_58 & 0,39 & 0,00 & 34,00 & 0,00 & 0,00 & 0,00 & 66,00 \\
\hline BH 1_59 & 0,81 & 30,80 & 49,48 & 0,00 & 0,00 & 0,00 & 19,72 \\
\hline BH 1_60 & 0,61 & 0,00 & 0,00 & 0,00 & 0,00 & 0,00 & 100,00 \\
\hline BH 1_61 & 1,31 & 0,00 & 0,00 & 0,00 & 0,00 & 0,00 & 100,00 \\
\hline BH 1_62 & 0,62 & 0,00 & 0,00 & 0,00 & 0,00 & 0,00 & 100,00 \\
\hline BH 1_63 & 0,52 & 0,00 & 1,40 & 0,00 & 0,00 & 0,00 & 98,60 \\
\hline BH 1_64 & 2,86 & 0,00 & 20,13 & 0,00 & 0,00 & 0,00 & 79,87 \\
\hline BH 1_65 & 15,38 & 0,00 & 35,00 & 0,00 & 0,00 & 0,00 & 65,00 \\
\hline BH 1_66 & 5,56 & 0,00 & 100,00 & 0,00 & 0,00 & 0,00 & 0,00 \\
\hline BH 1_67 & 1,35 & 0,00 & 100,00 & 0,00 & 0,00 & 0,00 & 0,00 \\
\hline BH 1_68 & 17,12 & 0,00 & 92,64 & 0,00 & 0,00 & 0,00 & 7,36 \\
\hline BH 1_69 & 10,66 & 0,00 & 31,00 & 0,00 & 0,00 & 0,00 & 69,00 \\
\hline BH 1_70 & 4,63 & 0,00 & 100,00 & 0,00 & 0,00 & 0,00 & 0,00 \\
\hline BH 1_71 & 1,40 & 1,72 & 0,00 & 0,00 & 57,05 & 0,00 & 41,23 \\
\hline BH 1_72 & 3,69 & 0,21 & 0,00 & 0,81 & 56,10 & 0,00 & 42,88 \\
\hline BH 1_73 & 3,93 & 0,00 & 80,90 & 0,00 & 0,00 & 0,00 & 19,10 \\
\hline BH 1_74 & 0,64 & 0,00 & 99,89 & 0,00 & 0,00 & 0,00 & 0,11 \\
\hline BH 1_75 & 15,77 & 0,00 & 0,00 & 0,00 & 0,00 & 0,00 & 100,00 \\
\hline BH 1_76 & 21,68 & 0,00 & 24,20 & 0,00 & 0,00 & 0,00 & 75,80 \\
\hline BH 1_77 & 0,77 & 0,00 & 69,87 & 0,00 & 0,00 & 0,00 & 30,13 \\
\hline BH 1_78 & 0,73 & 0,00 & 0,00 & 0,00 & 0,00 & 0,00 & 100,00 \\
\hline
\end{tabular}




\begin{tabular}{c|c|c|c|c|c|c|c}
\hline \multicolumn{7}{c}{ Substrato Rochoso $(\%)$} \\
\hline $\begin{array}{c}\text { Bacias } \\
\text { Hidrográficas }\end{array}$ & Área $\left(\mathrm{km}^{2}\right)$ & Coberturas Quaternárias & Gnaisse & Xisto & Quartzito & \multirow{2}{*}{ Milonito } & Xisto/Quartzito \\
\hline BH 1_79 & 0,23 & 14,60 & 0,00 & 0,00 & 85,20 & 0,00 & 0,20 \\
\hline BH 1_80 & 2,04 & 11,00 & 0,00 & 43,85 & 28,20 & 0,00 & 16,95 \\
\hline BH 1_81 & 2,45 & 0,00 & 100,00 & 0,00 & 0,00 & 0,00 & 0,00 \\
\hline BH 1_82 & 7,90 & 0,00 & 68,10 & 0,00 & 0,00 & 0,00 & 31,90 \\
\hline BH 1_83 & 13,75 & 0,00 & 0,00 & 0,00 & 0,00 & 0,00 & 100,00 \\
\hline BH 1_84 & 0,56 & 0,00 & 100,00 & 0,00 & 0,00 & 0,00 & 0,00 \\
\hline BH 1_85 & 10,84 & 0,00 & 45,30 & 0,00 & 0,00 & 0,00 & 5,70 \\
\hline
\end{tabular}




\begin{tabular}{|c|c|c|c|c|c|c|c|c|c|}
\hline \multicolumn{10}{|c|}{ Declividade (\%) } \\
\hline Bacias Hidrográficas & Área $\left(\mathrm{km}^{2}\right)$ & $0-2 \%$ & $2-5 \%$ & $5-10 \%$ & $10-15 \%$ & $15-20 \%$ & $20-30 \%$ & $30-45 \%$ & $>45 \%$ \\
\hline BH 1_1 & 1,05 & 10,26 & 23,19 & 23,43 & 18,13 & 9,91 & 9,78 & 4,02 & 1,28 \\
\hline BH 1_2 & 3,29 & 1,36 & 8,41 & 20,22 & 12,82 & 9,65 & 18,15 & 17,72 & 11,67 \\
\hline BH 1_3 & 0,89 & 0,14 & 1,00 & 3,10 & 7,95 & 10,83 & 20,38 & 27,67 & 28,93 \\
\hline BH 1_4 & 0,44 & 0,14 & 3,42 & 37,42 & 30,00 & 11,15 & 9,32 & 6,90 & 1,65 \\
\hline BH 1_5 & 0,93 & 0,25 & 2,81 & 13,98 & 11,81 & 17,07 & 23,40 & 22,10 & 8,58 \\
\hline BH 1_6 & 0,93 & 3,16 & 13,26 & 14,74 & 13,15 & 9,63 & 19,19 & 16,87 & 10,00 \\
\hline BH 1_7 & 2,12 & 2,80 & 18,18 & 46,58 & 20,40 & 5,91 & 4,75 & 1,38 & 0,00 \\
\hline BH 1_8 & 2,82 & 2,93 & 6,88 & 9,20 & 12,36 & 11,58 & 18,55 & 19,60 & 18,90 \\
\hline BH 1_9 & 2,34 & 3,63 & 19,33 & 37,03 & 14,12 & 4,74 & 6,00 & 8,78 & 6,37 \\
\hline BH 1_10 & 0,71 & 0,31 & 4,34 & 16,93 & 16,58 & 10,90 & 14,71 & 20,54 & 15,69 \\
\hline BH 1_11 & 0,37 & 0,00 & 0,19 & 3,58 & 15,36 & 14,88 & 25,75 & 26,56 & 13,68 \\
\hline BH 1_12 & 2,85 & 2,63 & 16,58 & 32,97 & 20,76 & 11,17 & 8,53 & 5,38 & 1,98 \\
\hline BH 1_13 & 1,54 & 0,47 & 2,94 & 14,69 & 20,58 & 13,01 & 12,40 & 16,44 & 19,47 \\
\hline BH 1_14 & 1,05 & 7,83 & 14,80 & 31,81 & 15,35 & 8,28 & 7,55 & 10,28 & 4,10 \\
\hline BH 1_15 & 2,09 & 1,20 & 6,17 & 16,07 & 18,38 & 7,53 & 10,82 & 22,10 & 17,73 \\
\hline BH 1_16 & 0,34 & 0,71 & 1,81 & 6,39 & 8,32 & 10,74 & 16,48 & 21,96 & 33,59 \\
\hline BH 1_17 & 1,29 & 1,03 & 5,33 & 19,70 & 13,62 & 7,95 & 12,29 & 24,50 & 15,58 \\
\hline BH 1_18 & 1,69 & 1,18 & 5,50 & 16,65 & 16,72 & 11,60 & 16,00 & 13,45 & 18,90 \\
\hline BH 1_19 & 1,48 & 0,86 & 2,85 & 14,99 & 19,40 & 14,43 & 24,81 & 16,00 & 6,66 \\
\hline BH 1_20 & 1,74 & 3,33 & 12,99 & 22,52 & 19,70 & 13,09 & 14,68 & 9,33 & 4,36 \\
\hline BH 1_21 & 0,34 & 0,00 & 0,00 & 6,71 & 6,78 & 6,43 & 17,68 & 20,08 & 42,32 \\
\hline BH 1_22 & 0,62 & 4,60 & 20,25 & 27,61 & 20,74 & 8,90 & 11,97 & 5,20 & 0,73 \\
\hline BH 1_23 & 0,90 & 22,04 & 13,98 & 11,63 & 8,45 & 8,22 & 15,58 & 11,70 & 8,40 \\
\hline BH 1_24 & 1,09 & 13,05 & 28,10 & 35,73 & 8,35 & 5,09 & 7,83 & 1,37 & 0,48 \\
\hline BH 1_25 & 3,57 & 6,77 & 12,83 & 16,09 & 14,57 & 12,70 & 16,17 & 11,80 & 9,07 \\
\hline BH 1_26 & 0,53 & 0,06 & 0,32 & 1,76 & 4,78 & 14,39 & 28,93 & 26,79 & 22,97 \\
\hline
\end{tabular}




\begin{tabular}{|c|c|c|c|c|c|c|c|c|c|}
\hline \multicolumn{10}{|c|}{ Declividade (\%) } \\
\hline Bacias Hidrográficas & Área $\left(\mathrm{km}^{2}\right)$ & $0-2 \%$ & $2-5 \%$ & $5-10 \%$ & $10-15 \%$ & $15-20 \%$ & $20-30 \%$ & $30-45 \%$ & $>45 \%$ \\
\hline BH 1_27 & 0,56 & 2,65 & 8,88 & 24,15 & 16,09 & 11,37 & 20,24 & 14,69 & 1,93 \\
\hline BH 1_28 & 1,45 & 4,78 & 9,85 & 20,77 & 23,23 & 18,10 & 15,89 & 5,42 & 1,96 \\
\hline BH 1_29 & 1,00 & 3,41 & 2,09 & 3,61 & 8,64 & 9,67 & 21,89 & 28,34 & 22,35 \\
\hline BH 1_30 & 0,80 & 0,52 & 1,68 & 5,70 & 12,64 & 18,06 & 25,58 & 16,79 & 19,03 \\
\hline BH 1_31 & 1,09 & 1,40 & 3,34 & 23,81 & 31,08 & 16,15 & 12,81 & 6,51 & 4,90 \\
\hline BH 1_32 & 0,65 & 2,70 & 2,90 & 10,63 & 23,83 & 20,61 & 16,34 & 10,70 & 12,29 \\
\hline BH 1_33 & 0,27 & 4,63 & 4,15 & 10,80 & 28,88 & 21,11 & 23,05 & 5,38 & 2,00 \\
\hline BH 1_34 & 1,03 & 1,73 & 7,60 & 26,33 & 24,55 & 15,32 & 15,82 & 6,64 & 2,01 \\
\hline $\mathrm{BH} 1 \_35$ & 0,37 & 1,80 & 10,04 & 58,12 & 18,12 & 6,12 & 3,41 & 1,45 & 0,94 \\
\hline $\mathrm{BH} 1 \_36$ & 1,19 & 6,98 & 9,14 & 19,37 & 23,67 & 17,26 & 13,25 & 7,44 & 2,89 \\
\hline BH 1_37 & 0,17 & 8,60 & 7,25 & 10,85 & 15,45 & 18,46 & 20,99 & 13,15 & 5,25 \\
\hline BH 1_38 & 0,63 & 0,57 & 5,80 & 33,08 & 27,56 & 11,29 & 10,25 & 7,78 & 3,67 \\
\hline BH 1_39 & 1,06 & 2,68 & 2,66 & 8,12 & 10,14 & 9,71 & 17,27 & 17,13 & 32,29 \\
\hline BH 1_40 & 0,32 & 1,22 & 5,21 & 32,81 & 26,13 & 16,31 & 12,74 & 5,33 & 0,25 \\
\hline BH 1_41 & 0,71 & 2,60 & 5,15 & 7,75 & 11,52 & 12,93 & 18,60 & 16,96 & 24,49 \\
\hline BH 1_42 & 0,47 & 1,39 & 7,50 & 29,20 & 28,95 & 18,82 & 12,05 & 2,09 & 0,00 \\
\hline BH 1_43 & 0,20 & 2,66 & 5,42 & 13,11 & 9,96 & 8,92 & 17,79 & 23,41 & 18,73 \\
\hline BH 1_44 & 1,32 & 4,97 & 29,97 & 36,24 & 13,11 & 6,96 & 5,65 & 2,72 & 0,38 \\
\hline BH 1_45 & 0,73 & 17,20 & 30,47 & 22,04 & 10,52 & 7,26 & 8,32 & 3,99 & 0,20 \\
\hline BH 1_46 & 1,74 & 5,60 & 17,96 & 42,77 & 16,84 & 6,87 & 6,08 & 2,10 & 1,78 \\
\hline BH 1_47 & 0,30 & 10,48 & 8,29 & 9,32 & 4,86 & 8,05 & 26,16 & 24,46 & 8,38 \\
\hline BH 1_48 & 2,19 & 5,50 & 7,10 & 11,36 & 13,51 & 15,56 & 24,54 & 14,93 & 7,50 \\
\hline BH 1_49 & 0,72 & 3,29 & 13,21 & 20,00 & 14,55 & 12,96 & 18,01 & 9,68 & 8,30 \\
\hline BH 1_50 & 1,16 & 5,26 & 11,20 & 20,76 & 21,89 & 17,76 & 16,34 & 6,40 & 0,39 \\
\hline BH 1_51 & 1,04 & 5,05 & 10,00 & 23,99 & 14,07 & 8,77 & 12,80 & 12,65 & 12,67 \\
\hline BH 1_52 & 1,56 & 3,31 & 10,16 & 19,74 & 21,11 & 15,81 & 18,24 & 9,57 & 2,06 \\
\hline
\end{tabular}




\begin{tabular}{|c|c|c|c|c|c|c|c|c|c|}
\hline \multicolumn{10}{|c|}{ Declividade (\%) } \\
\hline Bacias Hidrográficas & Área $\left(\mathrm{km}^{2}\right)$ & $0-2 \%$ & $2-5 \%$ & $5-10 \%$ & $10-15 \%$ & $15-20 \%$ & $20-30 \%$ & $30-45 \%$ & $>45 \%$ \\
\hline BH 1_53 & 1,27 & 6,61 & 24,56 & 25,83 & 19,38 & 10,62 & 9,93 & 2,97 & 0,10 \\
\hline BH 1_54 & 0,86 & 8,92 & 14,64 & 19,58 & 19,18 & 16,06 & 17,13 & 3,90 & 0,59 \\
\hline BH 1_55 & 0,13 & 8,21 & 40,30 & 15,12 & 12,43 & 7,90 & 9,67 & 5,60 & 0,77 \\
\hline BH 1_56 & 1,92 & 4,98 & 26,88 & 33,84 & 20,98 & 9,09 & 3,92 & 0,31 & 0,00 \\
\hline BH 1_57 & 2,56 & 4,50 & 29,39 & 34,36 & 12,30 & 9,08 & 8,31 & 1,92 & 0,14 \\
\hline BH 1_58 & 0,39 & 4,08 & 11,75 & 23,29 & 18,51 & 9,92 & 21,44 & 9,11 & 1,90 \\
\hline BH 1_59 & 0,81 & 2,55 & 18,09 & 29,00 & 18,72 & 12,80 & 11,93 & 5,13 & 1,78 \\
\hline BH 1_60 & 0,61 & 5,82 & 23,01 & 37,98 & 20,09 & 6,36 & 5,40 & 1,34 & 0,00 \\
\hline BH 1_61 & 1,31 & 16,45 & 25,52 & 24,54 & 13,34 & 9,64 & 7,42 & 2,74 & 0,35 \\
\hline BH 1_62 & 0,62 & 2,43 & 18,05 & 37,45 & 20,22 & 15,24 & 6,51 & 0,10 & 0,00 \\
\hline BH 1_63 & 0,52 & 6,03 & 24,41 & 36,77 & 21,43 & 9,91 & 1,16 & 0,29 & 0,00 \\
\hline BH 1_64 & 2,86 & 23,91 & 37,97 & 24,61 & 8,66 & 2,55 & 1,53 & 0,57 & 0,20 \\
\hline BH 1_65 & 15,38 & 40,68 & 22,40 & 18,35 & 8,79 & 4,72 & 3,53 & 1,30 & 0,23 \\
\hline BH 1_66 & 5,56 & 50,44 & 31,38 & 13,05 & 4,63 & 0,38 & 0,12 & 0,00 & 0,00 \\
\hline BH 1_67 & 1,35 & 14,06 & 37,19 & 33,73 & 10,35 & 4,08 & 0,59 & 0,00 & 0,00 \\
\hline BH 1_68 & 17,12 & 26,50 & 30,80 & 28,67 & 10,64 & 2,48 & 0,82 & 0,09 & 0,00 \\
\hline BH 1_69 & 10,66 & 19,03 & 30,43 & 32,13 & 13,70 & 3,33 & 1,16 & 0,20 & 0,02 \\
\hline BH 1_70 & 4,63 & 40,36 & 20,43 & 20,44 & 9,17 & 4,50 & 4,25 & 0,80 & 0,05 \\
\hline BH 1_71 & 1,40 & 0,52 & 6,98 & 13,72 & 13,50 & 13,44 & 21,38 & 19,16 & 11,30 \\
\hline BH 1_72 & 3,69 & 2,73 & 6,05 & 17,39 & 18,43 & 14,57 & 20,43 & 15,06 & 5,34 \\
\hline BH 1_73 & 3,93 & 15,55 & 34,92 & 30,88 & 10,73 & 3,97 & 2,62 & 1,07 & 0,26 \\
\hline BH 1_74 & 0,64 & 14,76 & 49,09 & 20,72 & 11,32 & 3,14 & 0,87 & 0,10 & 0,00 \\
\hline BH 1_75 & 15,77 & 12,97 & 31,83 & 33,32 & 15,61 & 4,42 & 1,61 & 0,23 & 0,01 \\
\hline BH 1_76 & 21,68 & 14,97 & 34,70 & 33,43 & 9,72 & 3,46 & 2,70 & 0,92 & 0,10 \\
\hline BH 1_77 & 0,77 & 4,87 & 36,17 & 30,32 & 14,16 & 5,81 & 7,15 & 1,40 & 0,12 \\
\hline BH 1_78 & 0,73 & 4,44 & 29,43 & 16,41 & 12,35 & 12,88 & 15,29 & 7,53 & 1,67 \\
\hline
\end{tabular}




\begin{tabular}{c|c|c|c|c|c|c|c|c|c|c|c}
\hline \multicolumn{7}{c}{ Declividade (\%) } \\
\hline Bacias Hidrográficas & Área $\left(\mathrm{km}^{2}\right)$ & $0-2 \%$ & $2-5 \%$ & $5-10 \%$ & $10-15 \%$ & $15-20 \%$ & $20-30 \%$ & $30-45 \%$ & $>45 \%$ \\
\hline BH 1_79 & 0,23 & 1,56 & 10,42 & 16,35 & 7,79 & 8,52 & 25,87 & 21,84 & 7,65 \\
\hline BH 1_80 & 2,04 & 2,59 & 11,74 & 18,70 & 12,83 & 13,33 & 22,17 & 14,00 & 4,64 \\
\hline BH 1_81 & 2,45 & 37,38 & 31,20 & 20,70 & 6,22 & 2,76 & 1,27 & 0,47 & 0,00 \\
\hline BH 1_82 & 7,90 & 14,58 & 32,08 & 27,33 & 14,20 & 6,48 & 4,20 & 1,00 & 0,13 \\
\hline BH 1_83 & 13,75 & 14,95 & 33,40 & 29,40 & 13,88 & 4,62 & 2,78 & 0,90 \\
\hline BH 1_84 & 0,56 & 22,01 & 28,18 & 38,78 & 7,69 & 1,90 & 1,44 & 0,07 \\
\hline BH 1_85 & 10,84 & 16,53 & 29,07 & 31,06 & 13,93 & 5,07 & 3,06 & 1,11 & 0,00 \\
\hline
\end{tabular}


APÊNDICE B - Percentual de área dos atributos do meio físico das bacias hidrográficas de $1^{\text {a }}$ ordem para a última análise de agrupamentos

\begin{tabular}{|c|c|c|c|c|c|c|c|c|}
\hline \multicolumn{9}{|c|}{ Materiais Inconsolidados (apenas aspecto textural) (\%) } \\
\hline $\begin{array}{c}\text { Bacias } \\
\text { Hidrográficas }\end{array}$ & $\begin{array}{l}\text { Área } \\
\left(\mathrm{km}^{2}\right)\end{array}$ & Areia & Silte & Silte e Rocha & $\begin{array}{l}\text { Distribuída } \\
\text { (Areia) }\end{array}$ & $\begin{array}{l}\text { Distribuída } \\
\text { (Silte) }\end{array}$ & $\begin{array}{c}\text { Distribuída } \\
\text { (Silte/Argila) }\end{array}$ & $\begin{array}{c}\text { Distribuída } \\
\text { (Argila/Silte/Areia) }\end{array}$ \\
\hline BH 1_1 & 1,05 & 0,00 & 0,00 & 0,00 & 0,00 & 41,58 & 58,42 & 0,00 \\
\hline BH 1_2 & 3,29 & 1,16 & 30,10 & 0,00 & 0,00 & 19,85 & 28,32 & 20,57 \\
\hline BH 1_3 & 38,34 & 0,00 & 0,00 & 0,00 & 100,00 & 0,00 & 0,00 & 0,00 \\
\hline BH 1_4 & 0,86 & 0,00 & 0,00 & 0,00 & 100,00 & 0,00 & 0,00 & 0,00 \\
\hline BH 1_5 & 0,13 & 0,00 & 0,00 & 0,00 & 100,00 & 0,00 & 0,00 & 0,00 \\
\hline BH 1_6 & 0,39 & 0,00 & 0,00 & 0,00 & 100,00 & 0,00 & 0,00 & 0,00 \\
\hline BH 1_7 & 2,86 & 0,00 & 0,00 & 0,00 & 88,00 & 0,00 & 12,00 & 0,00 \\
\hline BH 1_8 & 21,68 & 0,18 & 0,00 & 0,00 & 85,79 & 0,00 & 0,00 & 14,03 \\
\hline BH 1_9 & 10,66 & 0,00 & 0,00 & 0,00 & 100,00 & 0,00 & 0,00 & 0,00 \\
\hline BH 1_10 & 10,84 & 0,00 & 0,00 & 0,00 & 100,00 & 0,00 & 0,00 & 0,00 \\
\hline BH 1_11 & 15,38 & 0,00 & 0,00 & 0,00 & 74,63 & 0,00 & 1,40 & 23,97 \\
\hline BH 1_12 & 0,81 & 0,00 & 0,00 & 0,00 & 100,00 & 0,00 & 0,00 & 0,00 \\
\hline BH 1_13 & 3,93 & 26,89 & 0,00 & 0,00 & 73,11 & 0,00 & 0,00 & 0,00 \\
\hline BH 1_14 & 8,67 & 0,01 & 0,00 & 0,00 & 99,99 & 0,00 & 0,00 & 0,00 \\
\hline BH 1_15 & 12,64 & 0,00 & 0,00 & 0,00 & 100,00 & 0,00 & 0,00 & 0,00 \\
\hline BH 1_16 & 1,99 & 0,00 & 0,00 & 0,00 & 98,15 & 0,00 & 1,85 & 0,00 \\
\hline BH 1_17 & 17,12 & 0,00 & 0,00 & 0,00 & 100,00 & 0,00 & 0,00 & 0,00 \\
\hline BH 1_18 & 0,56 & 0,00 & 0,00 & 0,00 & 86,32 & 0,00 & 13,68 & 0,00 \\
\hline BH 1_19 & 0,44 & 6,32 & 93,68 & 0,00 & 0,00 & 0,00 & 0,00 & 0,00 \\
\hline BH 1_20 & 1,32 & 53,87 & 0,00 & 0,00 & 38,81 & 0,00 & 7,32 & 0,00 \\
\hline BH 1_21 & 0,73 & 100,00 & 0,00 & 0,00 & 0,00 & 0,00 & 0,00 & 0,00 \\
\hline BH 1_22 & 0,89 & 100,00 & 0,00 & 0,00 & 0,00 & 0,00 & 0,00 & 0,00 \\
\hline BH 1_23 & 0,23 & 100,00 & 0,00 & 0,00 & 0,00 & 0,00 & 0,00 & 0,00 \\
\hline BH 1_24 & 2,82 & 80,37 & 19,63 & 0,00 & 0,00 & 0,00 & 0,00 & 0,00 \\
\hline BH 1_25 & 3,63 & 90,29 & 9,71 & 0,00 & 0,00 & 0,00 & 0,00 & 0,00 \\
\hline BH 1_26 & 1,48 & 79,91 & 14,28 & 0,00 & 0,00 & 0,00 & 5,81 & 0,00 \\
\hline
\end{tabular}




\begin{tabular}{|c|c|c|c|c|c|c|c|c|}
\hline \multicolumn{9}{|c|}{ Materiais Inconsolidados (apenas aspecto textural) (\%) } \\
\hline $\begin{array}{c}\text { Bacias } \\
\text { Hidrográficas }\end{array}$ & $\begin{array}{l}\text { Área } \\
\left(\mathrm{km}^{2}\right)\end{array}$ & Areia & Silte & Silte e Rocha & $\begin{array}{l}\text { Distribuída } \\
\text { (Areia) }\end{array}$ & $\begin{array}{l}\text { Distribuída } \\
\text { (Silte) }\end{array}$ & $\begin{array}{c}\text { Distribuída } \\
\text { (Silte/Argila) }\end{array}$ & $\begin{array}{c}\text { Distribuída } \\
\text { (Argila/Silte/Areia) }\end{array}$ \\
\hline BH 1_27 & 0,71 & 69,57 & 30,43 & 0,00 & 0,00 & 0,00 & 0,00 & 0,00 \\
\hline BH 1_28 & 0,37 & 73,83 & 26,17 & 0,00 & 0,00 & 0,00 & 0,00 & 0,00 \\
\hline BH 1_29 & 0,34 & 58,61 & 40,31 & 0,00 & 0,00 & 0,00 & 1,08 & 0,00 \\
\hline BH 1_30 & 0,34 & 89,43 & 10,57 & 0,00 & 0,00 & 0,00 & 0,00 & 0,00 \\
\hline BH 1_31 & 2,34 & 62,23 & 37,77 & 0,00 & 0,00 & 0,00 & 0,00 & 0,00 \\
\hline BH 1_32 & 3,69 & 99,19 & 0,81 & 0,00 & 0,00 & 0,00 & 0,00 & 0,00 \\
\hline BH 1_33 & 0,93 & 0,00 & 46,20 & 53,80 & 0,00 & 0,00 & 0,00 & 0,00 \\
\hline BH 1_34 & 2,12 & 5,21 & 94,77 & 0,02 & 0,00 & 0,00 & 0,00 & 0,00 \\
\hline BH 1_ 35 & 0,17 & 4,38 & 86,83 & 8,79 & 0,00 & 0,00 & 0,00 & 0,00 \\
\hline BH 1_ 36 & 2,72 & 0,72 & 92,87 & 0,00 & 0,00 & 0,00 & 3,85 & 2,56 \\
\hline BH 1_37 & 1,04 & 15,34 & 62,93 & 0,00 & 0,00 & 0,00 & 21,73 & 0,00 \\
\hline BH 1_38 & 1,29 & 48,76 & 51,24 & 0,00 & 0,00 & 0,00 & 0,00 & 0,00 \\
\hline BH 1_39 & 2,04 & 26,10 & 38,00 & 0,00 & 0,00 & 0,00 & 18,98 & 16,92 \\
\hline BH 1_40 & 1,69 & 31,22 & 45,28 & 23,50 & 0,00 & 0,00 & 0,00 & 0,00 \\
\hline BH 1_41 & 1,06 & 29,26 & 57,84 & 12,90 & 0,00 & 0,00 & 0,00 & 0,00 \\
\hline BH 1_42 & 0,71 & 28,40 & 57,79 & 13,81 & 0,00 & 0,00 & 0,00 & 0,00 \\
\hline BH 1_43 & 1,53 & 21,94 & 78,05 & 0,00 & 0,00 & 0,00 & 0,01 & 0,00 \\
\hline BH 1_44 & 0,20 & 6,98 & 60,97 & 32,05 & 0,00 & 0,00 & 0,00 & 0,00 \\
\hline BH 1_45 & 2,34 & 33,61 & 66,39 & 0,00 & 0,00 & 0,00 & 0,00 & 0,00 \\
\hline BH 1_46 & 2,85 & 18,29 & 81,71 & 0,00 & 0,00 & 0,00 & 0,00 & 0,00 \\
\hline BH 1_47 & 1,05 & 22,94 & 77,06 & 0,00 & 0,00 & 0,00 & 0,00 & 0,00 \\
\hline BH 1_48 & 1,74 & 25,85 & 54,60 & 0,00 & 0,00 & 0,00 & 19,55 & 0,00 \\
\hline BH 1_49 & 0,62 & 11,23 & 43,53 & 18,04 & 0,00 & 0,00 & 27,20 & 0,00 \\
\hline BH 1_50 & 3,57 & 1,91 & 38,04 & 34,92 & 0,00 & 0,00 & 25,13 & 0,00 \\
\hline BH 1_51 & 0,56 & 0,00 & 88,47 & 0,00 & 0,00 & 0,00 & 11,53 & 0,00 \\
\hline BH 1_52 & 0,30 & 0,00 & 69,53 & 0,00 & 0,00 & 0,00 & 30,47 & 0,00 \\
\hline
\end{tabular}




\begin{tabular}{c|c|c|c|c|c|c|c|c}
\hline \multicolumn{7}{c}{ Materiais Inconsolidados (apenas aspecto textural) $(\%)$} \\
\hline $\begin{array}{c}\text { Bacias } \\
\text { Hidrográficas }\end{array}$ & $\begin{array}{c}\text { Área } \\
\left(\mathrm{km}^{2}\right)\end{array}$ & Areia & Silte & Silte e Rocha & $\begin{array}{c}\text { Distribuída } \\
\text { (Areia) }\end{array}$ & $\begin{array}{c}\text { Distribuída } \\
(\text { Silte) }\end{array}$ & $\begin{array}{c}\text { Distribuída } \\
\text { (Silte/Argila) }\end{array}$ & $\begin{array}{c}\text { Distribuída } \\
\text { (Argila/Silte/Areia) }\end{array}$ \\
\hline BH 1_53 & 2,19 & 0,00 & 86,63 & 0,00 & 0,00 & 0,00 & 13,37 & 0,00 \\
\hline BH 1_54 & 6,18 & 1,11 & 98,09 & 0,80 & 0,00 & 0,00 & 0,00 & 0,00 \\
\hline BH 1_55 & 0,27 & 0,00 & 100,00 & 0,00 & 0,00 & 0,00 & 0,00 & 0,00 \\
\hline BH 1_56 & 0,37 & 0,00 & 100,00 & 0,00 & 0,00 & 0,00 & 0,00 & 0,00 \\
\hline BH 1_57 & 1,74 & 0,00 & 93,68 & 0,00 & 0,00 & 0,00 & 6,32 & 0,00 \\
\hline BH 1_58 & 0,72 & 0,00 & 80,37 & 0,00 & 0,00 & 0,00 & 19,63 & 0,00 \\
\hline BH 1_59 & 0,80 & 14,86 & 85,14 & 0,00 & 0,00 & 0,00 & 0,00 & 0,00 \\
\hline BH 1_60 & 0,65 & 15,99 & 84,01 & 0,00 & 0,00 & 0,00 & 0,00 & \\
\hline BH 1_61 & 0,73 & 0,00 & 61,86 & 0,00 & 0,00 & 0,00 & 38,14 & \\
\hline BH 1_62 & 0,90 & 12,58 & 49,94 & 0,00 & 0,00 & 0,00 & 37,48 & 0,00 \\
\hline BH 1_63 & 1,09 & 0,00 & 36,94 & 0,00 & 0,00 & 0,00 & 0,00 & 63,06 \\
\hline
\end{tabular}




\begin{tabular}{|c|c|c|c|c|c|c|c|}
\hline \multicolumn{8}{|c|}{ Substrato Rochoso (\%) } \\
\hline Bacias Hidrográficas & Área $\left(\mathrm{km}^{2}\right)$ & Coberturas Quaternárias & Gnaisse & Xisto & Quartzito & Milonito & Xisto/Quartzito \\
\hline BH 1_1 & 1,05 & 0,00 & 100,00 & 0,00 & 0,00 & 0,00 & 0,00 \\
\hline BH 1_2 & 3,29 & 0,00 & 62,40 & 0,00 & 0,71 & 0,00 & 36,89 \\
\hline BH 1_3 & 38,34 & 0,00 & 0,08 & 0,00 & 0,00 & 0,00 & 99,92 \\
\hline BH 1_4 & 0,86 & 0,00 & 0,00 & 0,00 & 0,00 & 0,00 & 100,00 \\
\hline BH 1_5 & 0,13 & 0,00 & 0,00 & 0,00 & 0,00 & 0,00 & 100,00 \\
\hline BH 1_6 & 0,39 & 0,00 & 34,00 & 0,00 & 0,00 & 0,00 & 66,00 \\
\hline BH 1_7 & 2,86 & 0,00 & 20,04 & 0,00 & 0,00 & 0,00 & 79,96 \\
\hline BH 1_8 & 21,68 & 0,00 & 24,20 & 0,00 & 0,00 & 0,00 & 75,80 \\
\hline BH 1_9 & 10,66 & 0,00 & 31,00 & 0,00 & 0,00 & 0,00 & 69,00 \\
\hline BH 1_10 & 10,84 & 0,00 & 45,30 & 0,00 & 0,00 & 0,00 & 54,70 \\
\hline BH 1_11 & 15,38 & 0,00 & 35,00 & 0,00 & 0,00 & 0,00 & 65,00 \\
\hline BH 1_12 & 0,81 & 30,85 & 49,43 & 0,00 & 0,00 & 0,00 & 19,72 \\
\hline BH 1_13 & 3,93 & 0,00 & 80,82 & 0,00 & 0,00 & 0,00 & 19,18 \\
\hline BH 1_14 & 8,67 & 0,00 & 68,23 & 0,00 & 0,00 & 0,00 & 31,77 \\
\hline BH 1_15 & 12,64 & 0,00 & 100,00 & 0,00 & 0,00 & 0,00 & 0,00 \\
\hline BH 1_16 & 1,99 & 0,00 & 99,89 & 0,00 & 0,00 & 0,00 & 0,11 \\
\hline BH 1_17 & 17,12 & 0,00 & 92,64 & 0,00 & 0,00 & 0,00 & 7,36 \\
\hline BH 1_18 & 0,56 & 0,00 & 100,00 & 0,00 & 0,00 & 0,00 & 0,00 \\
\hline BH 1_19 & 0,44 & 0,00 & 0,00 & 0,00 & 7,22 & 0,00 & 92,78 \\
\hline BH 1_20 & 1,32 & 0,00 & 0,14 & 0,00 & 0,00 & 0,00 & 99,86 \\
\hline BH 1_21 & 0,73 & 0,00 & 0,00 & 0,00 & 0,00 & 0,00 & 100,00 \\
\hline BH 1_22 & 0,89 & 11,39 & 0,00 & 0,00 & 88,61 & 0,00 & 0,00 \\
\hline BH 1_23 & 0,23 & 14,60 & 0,00 & 0,00 & 85,20 & 0,00 & 0,20 \\
\hline BH 1_24 & 2,82 & 0,00 & 0,00 & 13,48 & 72,95 & 13,57 & 0,00 \\
\hline BH 1_25 & 3,63 & 0,00 & 0,00 & 6,76 & 93,24 & 0,00 & 0,00 \\
\hline BH 1_26 & 1,48 & 22,89 & 0,00 & 10,93 & 48,21 & 17,97 & 0,00 \\
\hline
\end{tabular}




\begin{tabular}{|c|c|c|c|c|c|c|c|}
\hline \multicolumn{8}{|c|}{ Substrato Rochoso (\%) } \\
\hline Bacias Hidrográficas & Área $\left(\mathrm{km}^{2}\right)$ & Coberturas Quaternárias & Gnaisse & Xisto & Quartzito & Milonito & Xisto/Quartzito \\
\hline BH 1_27 & 0,71 & 0,00 & 0,00 & 45,04 & 54,58 & 0,38 & 0,00 \\
\hline BH 1_28 & 0,37 & 0,00 & 0,00 & 51,02 & 48,98 & 0,00 & 0,00 \\
\hline BH 1_29 & 0,34 & 4,67 & 0,00 & 36,72 & 58,61 & 0,00 & 0,00 \\
\hline BH 1_30 & 0,34 & 0,00 & 0,00 & 34,38 & 65,62 & 0,00 & 0,00 \\
\hline BH 1_31 & 2,34 & 1,03 & 0,00 & 0,00 & 61,20 & 0,00 & 37,77 \\
\hline BH 1_32 & 3,69 & 0,21 & 0,00 & 0,81 & 56,10 & 0,00 & 42,88 \\
\hline BH 1_33 & 0,93 & 0,00 & 0,00 & 96,02 & 0,00 & 0,00 & 3,98 \\
\hline BH 1_34 & 2,12 & 0,00 & 0,00 & 81,70 & 12,10 & 6,20 & 0,00 \\
\hline BH 1_35 & 0,17 & 0,00 & 0,00 & 84,73 & 4,38 & 10,89 & 0,00 \\
\hline BH 1_36 & 2,72 & 0,00 & 0,00 & 96,72 & 0,72 & 0,00 & 2,56 \\
\hline BH 1_37 & 1,04 & 0,00 & 0,00 & 84,51 & 15,49 & 0,00 & 0,00 \\
\hline BH 1_38 & 1,29 & 27,29 & 0,00 & 51,24 & 21,47 & 0,00 & 0,00 \\
\hline BH 1_39 & 2,04 & 11,00 & 0,00 & 43,85 & 28,20 & 0,00 & 16,95 \\
\hline BH 1_40 & 1,69 & 8,33 & 0,00 & 66,78 & 24,89 & 0,00 & 0,00 \\
\hline BH 1_41 & 1,06 & 0,00 & 0,00 & 60,32 & 29,26 & 10,42 & 0,00 \\
\hline BH 1_42 & 0,71 & 0,00 & 0,00 & 46,99 & 28,40 & 24,61 & 0,00 \\
\hline BH 1_43 & 1,53 & 4,54 & 0,00 & 70,58 & 21,94 & 2,94 & 0,00 \\
\hline BH 1_44 & 0,20 & 0,00 & 0,00 & 70,35 & 6,98 & 22,67 & 0,00 \\
\hline BH 1_45 & 2,34 & 0,00 & 0,00 & 2,66 & 40,06 & 57,28 & 0,00 \\
\hline BH 1_46 & 2,85 & 0,00 & 0,00 & 14,14 & 24,75 & 61,11 & 0,00 \\
\hline BH 1_47 & 1,05 & 0,00 & 0,00 & 38,86 & 22,07 & 39,07 & 0,00 \\
\hline BH 1_48 & 1,74 & 23,54 & 0,00 & 7,58 & 24,55 & 44,33 & 0,00 \\
\hline BH 1_49 & 0,62 & 25,53 & 0,00 & 18,04 & 0,00 & 56,43 & 0,00 \\
\hline BH 1_50 & 3,57 & 31,45 & 0,00 & 20,31 & 1,91 & 46,33 & 0,00 \\
\hline BH 1_51 & 0,56 & 5,52 & 0,00 & 40,72 & 0,00 & 53,76 & 0,00 \\
\hline BH 1_52 & 0,30 & 42,19 & 0,00 & 28,98 & 0,00 & 28,83 & 0,00 \\
\hline
\end{tabular}




\begin{tabular}{|c|c|c|c|c|c|c|c|}
\hline \multicolumn{8}{|c|}{ Substrato Rochoso (\%) } \\
\hline Bacias Hidrográficas & Área $\left(\mathrm{km}^{2}\right)$ & Coberturas Quaternárias & Gnaisse & Xisto & Quartzito & Milonito & Xisto/Quartzito \\
\hline BH 1_53 & 2,19 & 32,45 & 0,00 & 40,12 & 0,00 & 27,43 & 0,00 \\
\hline BH 1_54 & 6,18 & 0,00 & 0,00 & 1,11 & 1,11 & 94,69 & 3,09 \\
\hline BH 1_55 & 0,27 & 0,00 & 0,00 & 0,00 & 0,00 & 99,58 & 0,42 \\
\hline BH 1_56 & 0,37 & 0,00 & 0,00 & 4,86 & 0,00 & 95,14 & 0,00 \\
\hline BH 1_57 & 1,74 & 0,00 & 0,00 & 0,00 & 0,00 & 100,00 & 0,00 \\
\hline BH 1_58 & 0,72 & 19,92 & 0,00 & 0,00 & 0,00 & 80,08 & 0,00 \\
\hline BH 1_59 & 0,80 & 0,00 & 0,00 & 0,00 & 14,87 & 61,85 & 23,28 \\
\hline BH 1_60 & 0,65 & 0,00 & 0,00 & 0,00 & 15,99 & 69,88 & 14,13 \\
\hline BH 1_61 & 0,73 & 0,00 & 0,00 & 0,00 & 0,00 & 100,00 & 0,00 \\
\hline BH 1_62 & 0,90 & 58,98 & 0,00 & 28,52 & 8,96 & 3,54 & 0,00 \\
\hline BH 1_63 & 1,09 & 61,10 & 0,00 & 0,00 & 0,00 & 38,90 & 0,00 \\
\hline
\end{tabular}




\begin{tabular}{|c|c|c|c|c|c|c|c|c|c|}
\hline \multicolumn{10}{|c|}{ Declividade (\%) } \\
\hline $\begin{array}{c}\text { Bacias } \\
\text { Hidrográficas }\end{array}$ & Área $\left(\mathrm{km}^{2}\right)$ & $0-2 \%$ & $2-5 \%$ & $5-10 \%$ & $10-15 \%$ & $15-20 \%$ & $20-30 \%$ & $30-45 \%$ & $>45 \%$ \\
\hline BH 1_1 & 1,05 & 10,26 & 23,25 & 23,36 & 18,17 & 9,89 & 9,79 & 4,03 & 1,25 \\
\hline BH 1_2 & 3,29 & 1,40 & 8,47 & 20,20 & 12,81 & 9,63 & 18,13 & 17,69 & 11,67 \\
\hline BH 1_3 & 38,34 & 12,20 & 31,04 & 31,68 & 15,32 & 5,71 & 3,21 & 0,78 & 0,06 \\
\hline BH 1_4 & 0,86 & 8,84 & 14,77 & 19,57 & 19,18 & 16,03 & 17,13 & 3,89 & 0,59 \\
\hline BH 1_5 & 0,13 & 8,19 & 40,24 & 15,30 & 12,39 & 7,88 & 9,64 & 5,59 & 0,77 \\
\hline BH 1_6 & 0,39 & 3,97 & 11,86 & 22,99 & 18,61 & 10,02 & 21,52 & 9,13 & 1,90 \\
\hline BH 1_7 & 2,86 & 24,09 & 37,88 & 24,53 & 8,64 & 2,55 & 1,53 & 0,57 & 0,21 \\
\hline BH 1_8 & 21,68 & 14,98 & 34,70 & 33,43 & 9,72 & 3,46 & 2,70 & 0,91 & 0,10 \\
\hline BH 1_9 & 10,66 & 18,99 & 30,47 & 32,13 & 13,70 & 3,33 & 1,16 & 0,20 & 0,02 \\
\hline BH 1_10 & 10,84 & 16,52 & 29,10 & 31,04 & 13,93 & 5,07 & 3,06 & 1,11 & 0,17 \\
\hline BH 1_11 & 15,38 & 40,65 & 22,40 & 18,37 & 8,81 & 4,72 & 3,52 & 1,30 & 0,23 \\
\hline BH 1_12 & 0,81 & 2,56 & 18,08 & 29,10 & 18,70 & 12,68 & 11,93 & 5,15 & 1,80 \\
\hline BH 1_13 & 3,93 & 15,53 & 34,86 & 30,92 & 10,74 & 3,98 & 2,63 & 1,07 & 0,27 \\
\hline BH 1_14 & 8,67 & 13,78 & 32,31 & 27,63 & 14,23 & 6,43 & 4,46 & 1,04 & 0,12 \\
\hline BH 1_15 & 12,64 & 44,13 & 27,36 & 17,27 & 6,61 & 2,35 & 1,86 & 0,40 & 0,02 \\
\hline BH 1_16 & 1,99 & 14,27 & 41,10 & 29,49 & 10,65 & 3,78 & 0,68 & 0,03 & 0,00 \\
\hline BH 1_17 & 17,12 & 26,56 & 30,79 & 28,62 & 10,64 & 2,48 & 0,82 & 0,09 & 0,00 \\
\hline BH 1_18 & 0,56 & 22,00 & 28,15 & 38,80 & 7,71 & 1,90 & 1,44 & 0,00 & 0,00 \\
\hline BH 1_19 & 0,44 & 0,14 & 3,78 & 37,24 & 29,86 & 11,04 & 9,30 & 6,97 & 1,67 \\
\hline BH 1_20 & 1,32 & 4,91 & 29,81 & 36,33 & 13,15 & 6,97 & 5,67 & 2,76 & 0,40 \\
\hline BH 1_21 & 0,73 & 4,34 & 29,33 & 16,39 & 12,44 & 12,90 & 15,32 & 7,62 & 1,66 \\
\hline BH 1_22 & 0,89 & 0,13 & 0,98 & 3,08 & 8,01 & 10,82 & 20,37 & 27,63 & 28,98 \\
\hline BH 1_23 & 0,23 & 1,74 & 10,90 & 16,42 & 7,57 & 8,12 & 25,67 & 22,11 & 7,47 \\
\hline BH 1_24 & 2,82 & 2,81 & 6,79 & 9,25 & 12,40 & 11,59 & 18,58 & 19,64 & 18,94 \\
\hline BH 1_25 & 3,63 & 0,92 & 4,82 & 15,52 & 19,27 & 9,82 & 11,47 & 19,73 & 18,45 \\
\hline BH 1_26 & 1,48 & 0,83 & 2,84 & 15,08 & 19,36 & 14,45 & 24,80 & 15,98 & 6,66 \\
\hline
\end{tabular}




\begin{tabular}{|c|c|c|c|c|c|c|c|c|c|}
\hline \multicolumn{10}{|c|}{ Declividade (\%) } \\
\hline $\begin{array}{c}\text { Bacias } \\
\text { Hidrográficas }\end{array}$ & Área $\left(\mathrm{km}^{2}\right)$ & $0-2 \%$ & $2-5 \%$ & $5-10 \%$ & $10-15 \%$ & $15-20 \%$ & $20-30 \%$ & $30-45 \%$ & $>45 \%$ \\
\hline BH 1_27 & 0,71 & 0,27 & 4,16 & 17,09 & 16,55 & 10,90 & 14,68 & 20,66 & 15,69 \\
\hline BH 1_28 & 0,37 & 0,00 & 0,24 & 3,71 & 15,26 & 14,93 & 25,86 & 26,29 & 13,71 \\
\hline BH 1_29 & 0,34 & 0,00 & 0,00 & 6,96 & 6,60 & 6,43 & 17,73 & 19,98 & 42,30 \\
\hline BH 1_30 & 0,34 & 0,95 & 1,86 & 6,50 & 8,24 & 10,63 & 16,20 & 21,77 & 33,85 \\
\hline BH 1_31 & 2,34 & 0,40 & 5,28 & 13,78 & 12,83 & 14,91 & 22,21 & 20,35 & 10,24 \\
\hline BH 1_32 & 3,69 & 2,59 & 5,98 & 17,40 & 18,48 & 14,57 & 20,44 & 15,14 & 5,40 \\
\hline BH 1_33 & 0,93 & 3,18 & 13,30 & 14,72 & 13,12 & 9,62 & 19,17 & 16,87 & 10,02 \\
\hline BH 1_34 & 2,12 & 2,89 & 18,37 & 46,44 & 20,36 & 5,89 & 4,67 & 1,38 & 0,00 \\
\hline BH 1_ 35 & 0,17 & 7,50 & 7,50 & 11,34 & 15,95 & 18,90 & 21,09 & 12,70 & 5,02 \\
\hline BH 1_ 36 & 2,72 & 4,14 & 10,61 & 20,18 & 21,43 & 16,65 & 17,42 & 8,21 & 1,35 \\
\hline BH 1_37 & 1,04 & 4,86 & 9,76 & 24,03 & 14,12 & 8,80 & 12,94 & 12,74 & 12,75 \\
\hline BH 1_38 & 1,29 & 0,92 & 5,28 & 19,72 & 13,62 & 7,94 & 12,30 & 24,58 & 15,64 \\
\hline BH 1_39 & 2,04 & 2,65 & 11,95 & 18,76 & 12,67 & 13,25 & 22,07 & 14,00 & 4,65 \\
\hline BH 1_40 & 1,69 & 0,95 & 5,47 & 16,70 & 16,77 & 11,64 & 16,05 & 13,49 & 18,93 \\
\hline BH 1_41 & 1,06 & 2,74 & 2,67 & 8,13 & 10,15 & 9,70 & 17,27 & 17,08 & 32,26 \\
\hline BH 1_42 & 0,71 & 2,56 & 5,21 & 7,80 & 11,58 & 12,87 & 18,58 & 16,92 & 24,48 \\
\hline BH 1_43 & 1,53 & 2,35 & 1,51 & 2,99 & 7,29 & 11,32 & 24,27 & 27,75 & 22,52 \\
\hline BH 1_44 & 0,20 & 1,98 & 5,33 & 13,19 & 9,98 & 8,99 & 17,93 & 23,46 & 19,14 \\
\hline BH 1_45 & 2,34 & 3,70 & 19,46 & 36,86 & 14,10 & 4,74 & 6,03 & 8,76 & 6,35 \\
\hline BH 1_46 & 2,85 & 2,67 & 16,60 & 32,95 & 20,77 & 11,15 & 8,52 & 5,37 & 1,97 \\
\hline BH 1_47 & 1,05 & 7,65 & 14,87 & 31,94 & 15,38 & 8,26 & 7,59 & 10,21 & 4,10 \\
\hline BH 1_48 & 1,74 & 3,39 & 13,18 & 22,40 & 19,54 & 13,07 & 14,73 & 9,34 & 4,35 \\
\hline BH 1_49 & 0,62 & 4,79 & 20,44 & 27,50 & 20,62 & 8,86 & 11,90 & 5,16 & 0,73 \\
\hline BH 1_50 & 3,57 & 6,78 & 12,84 & 16,09 & 14,59 & 12,69 & 16,17 & 11,79 & 9,05 \\
\hline BH 1_51 & 0,56 & 2,86 & 8,92 & 24,16 & 16,00 & 11,33 & 20,14 & 14,66 & 1,93 \\
\hline BH 1_52 & 0,30 & 10,45 & 8,36 & 9,35 & 4,86 & 8,12 & 26,20 & 24,30 & 8,36 \\
\hline
\end{tabular}




\begin{tabular}{c|c|c|c|c|c|c|c|c|c}
\hline \multicolumn{7}{c}{ Declividade (\%) } \\
\hline $\begin{array}{c}\text { Bacias } \\
\text { Hidrográficas }\end{array}$ & Área $\left(\mathrm{km}^{2}\right)$ & $0-2 \%$ & $2-5 \%$ & $5-10 \%$ & $10-15 \%$ & $15-20 \%$ & $20-30 \%$ & $30-45 \%$ & $>45 \%$ \\
\hline BH 1_53 & 2,19 & 5,40 & 7,05 & 11,25 & 13,53 & 15,72 & 24,58 & 14,94 & 7,53 \\
\hline BH 1_54 & 6,18 & 3,21 & 7,35 & 24,50 & 25,95 & 16,40 & 13,80 & 6,19 & 2,60 \\
\hline BH 1_55 & 0,27 & 4,60 & 4,00 & 10,84 & 29,04 & 21,08 & 23,06 & 5,34 & 2,04 \\
\hline BH 1_56 & 0,37 & 1,50 & 10,01 & 58,40 & 18,20 & 6,07 & 3,38 & 1,50 & 0,94 \\
\hline BH 1_57 & 1,74 & 5,78 & 17,97 & 42,64 & 16,81 & 6,87 & 6,06 & 2,08 & 1,79 \\
\hline BH 1_58 & 0,72 & 3,27 & 12,97 & 19,98 & 14,66 & 12,93 & 18,00 & 9,84 & 8,35 \\
\hline BH 1_59 & 0,80 & 0,56 & 1,67 & 5,67 & 12,56 & 18,11 & 25,67 & 16,67 & 19,09 \\
\hline BH 1_60 & 0,65 & 2,77 & 2,82 & 10,52 & 23,94 & 20,69 & 16,35 & 10,55 & 12,36 \\
\hline BH 1_61 & 0,73 & 16,66 & 31,03 & 22,05 & 10,62 & 7,22 & 8,27 & 3,96 & 0,19 \\
\hline BH 1_62 & 0,90 & 21,70 & 13,88 & 11,71 & 8,52 & 8,40 & 15,58 & 11,71 & 8,50 \\
\hline BH 1_63 & 1,09 & 12,84 & 28,10 & 35,84 & 8,40 & 5,11 & 7,86 & 1,37 & 0,48 \\
\hline
\end{tabular}



APÊNDICE C - Índices morfométricos das bacias hidrográficas de $2^{\mathrm{a}}$ ordem

\begin{tabular}{|c|c|c|c|c|c|c|c|c|c|}
\hline $\begin{array}{c}\text { Bacias } \\
\text { Hidrográficas }\end{array}$ & $\begin{array}{l}\text { Índice de } \\
\text { Forma }\end{array}$ & $\begin{array}{c}\text { Índice de } \\
\text { Circularidade }\end{array}$ & $\begin{array}{c}\text { Densidade } \\
\text { de } \\
\text { Drenagem }\end{array}$ & $\begin{array}{l}\text { Densidade } \\
\text { Hidrográfica }\end{array}$ & $\begin{array}{c}\text { Relação de } \\
\text { Relevo }\end{array}$ & $\begin{array}{c}\text { Extensão do } \\
\text { percurso } \\
\text { superficial }\end{array}$ & $\begin{array}{l}\text { Coeficiente } \\
\text { de } \\
\text { manutenção }\end{array}$ & $\begin{array}{c}\text { Índice de } \\
\text { Rugosidade }\end{array}$ & $\begin{array}{c}\text { Textura } \\
\text { Topográfica }\end{array}$ \\
\hline BH 2_1 & 1,34 & 0,56 & 1,83 & 3,32 & 0,36 & 273,85 & 547,70 & 0,56 & 3,24 \\
\hline BH 2_2 & 1,25 & 0,64 & 2,25 & 2,50 & 0,24 & 222,01 & 444,02 & 0,81 & 4,10 \\
\hline BH 2_3 & 1,22 & 0,67 & 1,98 & 2,76 & 0,17 & 252,55 & 505,11 & 0,45 & 3,55 \\
\hline BH 2_4 & 1,19 & 0,71 & 2,05 & 1,80 & 0,11 & 243,90 & 487,81 & 0,34 & 3,69 \\
\hline BH 2_5 & 1,17 & 0,73 & 2,84 & 3,73 & 0,12 & 176,10 & 352,20 & 0,98 & 5,31 \\
\hline BH 2_6 & 1,39 & 0,52 & 1,77 & 1,38 & 0,14 & 282,72 & 565,45 & 0,63 & 3,13 \\
\hline BH 2_7 & 1,29 & 0,60 & 2,04 & 1,80 & 0,12 & 245,48 & 490,96 & 0,79 & 3,67 \\
\hline BH 2_8 & 1,29 & 0,60 & 2,68 & 1,78 & 0,15 & 186,59 & 373,18 & 0,98 & 4,98 \\
\hline BH 2_9 & 1,22 & 0,67 & 3,33 & 6,21 & 0,38 & 149,98 & 299,96 & 0,98 & 6,35 \\
\hline BH 2_10 & 1,15 & 0,75 & 1,48 & 2,31 & 0,16 & 337,52 & 675,03 & 0,30 & 2,57 \\
\hline BH 2_11 & 1,17 & 0,73 & 1,12 & 0,81 & 0,13 & 446,33 & 892,66 & 0,32 & 1,88 \\
\hline BH 2_12 & 1,45 & 0,47 & 1,90 & 1,43 & 0,18 & 262,50 & 525,01 & 0,93 & 3,40 \\
\hline BH 2_13 & 1,28 & 0,61 & 1,75 & 2,42 & 0,10 & 286,48 & 572,95 & 0,41 & 3,09 \\
\hline BH 2_14 & 1,38 & 0,53 & 1,67 & 1,11 & 0,11 & 298,71 & 597,43 & 0,82 & 2,95 \\
\hline BH 2_15 & 1,49 & 0,45 & 2,56 & 2,41 & 0,10 & 195,52 & 391,04 & 0,47 & 4,72 \\
\hline BH 2_16 & 1,58 & 0,40 & 1,95 & 1,73 & 0,13 & 255,82 & 511,64 & 0,62 & 3,50 \\
\hline BH 2_17 & 1,49 & 0,45 & 2,04 & 2,64 & 0,14 & 245,30 & 490,60 & 0,62 & 3,67 \\
\hline BH 2_18 & 1,49 & 0,45 & 1,74 & 1,68 & 0,19 & 286,58 & 573,16 & 0,99 & 3,08 \\
\hline BH 2_19 & 1,37 & 0,53 & 1,67 & 1,38 & 0,21 & 299,77 & 599,53 & 0,95 & 2,93 \\
\hline BH 2_20 & 1,64 & 0,37 & 0,92 & 0,74 & 0,13 & 543,06 & 1086,12 & 0,30 & 1,51 \\
\hline BH 2_21 & 1,33 & 0,56 & 1,61 & 1,72 & 0,16 & 310,86 & 621,72 & 0,52 & 2,82 \\
\hline BH 2_22 & 1,45 & 0,48 & 1,82 & 1,61 & 0,14 & 274,30 & 548,61 & 0,58 & 3,24 \\
\hline BH 2_23 & 1,18 & 0,72 & 2,04 & 2,74 & 0,24 & 244,76 & 489,53 & 0,86 & 3,68 \\
\hline BH 2_24 & 1,36 & 0,54 & 1,91 & 1,76 & 0,17 & 262,12 & 524,24 & 1,07 & 3,41 \\
\hline BH 2_25 & 1,41 & 0,50 & 1,47 & 1,44 & 0,21 & 339,13 & 678,26 & 0,80 & 2,56 \\
\hline
\end{tabular}




\begin{tabular}{|c|c|c|c|c|c|c|c|c|c|}
\hline $\begin{array}{c}\text { Bacias } \\
\text { Hidrográficas }\end{array}$ & $\begin{array}{l}\text { Índice de } \\
\text { Forma }\end{array}$ & $\begin{array}{c}\text { Índice de } \\
\text { Circularidade }\end{array}$ & $\begin{array}{l}\text { Densidade de } \\
\text { Drenagem }\end{array}$ & $\begin{array}{l}\text { Densidade } \\
\text { Hidrográfica }\end{array}$ & $\begin{array}{c}\text { Relação de } \\
\text { Relevo }\end{array}$ & $\begin{array}{c}\text { Extensão do } \\
\text { percurso } \\
\text { superficial }\end{array}$ & $\begin{array}{l}\text { Coeficiente de } \\
\text { manutenção }\end{array}$ & $\begin{array}{c}\text { Índice de } \\
\text { Rugosidade }\end{array}$ & $\begin{array}{c}\text { Textura } \\
\text { Topográfica }\end{array}$ \\
\hline BH 2_26 & 1,41 & 0,50 & 1,32 & 2,20 & 0,45 & 380,11 & 760,22 & 0,62 & 2,25 \\
\hline BH 2_27 & 1,35 & 0,55 & 1,64 & 2,80 & 0,29 & 305,61 & 611,23 & 0,71 & 2,87 \\
\hline BH 2_28 & 1,20 & 0,70 & 1,92 & 1,89 & 0,08 & 260,68 & 521,35 & 0,25 & 3,43 \\
\hline BH 2_29 & 1,38 & 0,53 & 1,99 & 1,43 & 0,27 & 251,42 & 502,83 & 1,12 & 3,57 \\
\hline BH 2_30 & 1,34 & 0,56 & 1,76 & 2,43 & 0,46 & 283,81 & 567,62 & 1,05 & 3,12 \\
\hline BH 2_31 & 1,43 & 0,49 & 2,15 & 1,90 & 0,21 & 232,25 & 464,49 & 1,26 & 3,90 \\
\hline BH 2_32 & 1,63 & 0,37 & 1,38 & 1,54 & 0,28 & 362,35 & 724,71 & 0,78 & 2,37 \\
\hline BH 2_33 & 1,27 & 0,62 & 1,66 & 1,93 & 0,24 & 300,32 & 600,64 & 0,52 & 2,93 \\
\hline BH 2_34 & 1,37 & 0,53 & 2,83 & 3,05 & 0,18 & 176,84 & 353,67 & 0,98 & 5,28 \\
\hline $\mathrm{BH} 2 \_35$ & 1,46 & 0,47 & 2,19 & 2,37 & 0,31 & 228,37 & 456,73 & 1,11 & 3,97 \\
\hline BH 2_36 & 1,42 & 0,50 & 2,93 & 2,31 & 0,22 & 170,91 & 341,83 & 1,15 & 5,49 \\
\hline BH 2_37 & 1,33 & 0,56 & 2,16 & 2,60 & 0,25 & 231,50 & 463,00 & 1,16 & 3,91 \\
\hline BH 2_38 & 1,31 & 0,58 & 4,18 & 4,39 & 0,24 & 119,49 & 238,98 & 1,79 & 8,18 \\
\hline BH 2_39 & 1,42 & 0,49 & 3,35 & 2,87 & 0,20 & 149,19 & 298,39 & 1,44 & 6,39 \\
\hline BH 2_40 & 1,38 & 0,53 & 2,34 & 3,12 & 0,26 & 214,08 & 428,15 & 1,19 & 4,27 \\
\hline BH 2_41 & 1,53 & 0,43 & 2,42 & 2,94 & 0,23 & 206,89 & 413,79 & 1,19 & 4,44 \\
\hline BH 2_42 & 1,31 & 0,58 & 3,36 & 8,54 & 0,17 & 148,92 & 297,84 & 0,29 & 6,40 \\
\hline BH 2_43 & 1,43 & 0,49 & 3,82 & 9,35 & 0,25 & 130,97 & 261,93 & 0,67 & 7,39 \\
\hline BH 2_44 & 1,85 & 0,29 & 2,59 & 4,22 & 0,34 & 193,12 & 386,25 & 1,31 & 4,79 \\
\hline BH 2_45 & 1,41 & 0,50 & 2,77 & 2,63 & 0,16 & 180,22 & 360,43 & 0,88 & 5,17 \\
\hline BH 2_46 & 1,32 & 0,57 & 2,08 & 3,59 & 0,12 & 240,52 & 481,04 & 0,22 & 3,75 \\
\hline BH 2_47 & 1,31 & 0,59 & 2,63 & 3,87 & 0,61 & 189,85 & 379,69 & 1,26 & 4,88 \\
\hline BH 2_48 & 1,59 & 0,40 & 2,07 & 2,42 & 0,28 & 241,31 & 482,63 & 0,98 & 3,74 \\
\hline BH 2_49 & 1,24 & 0,65 & 2,04 & 2,51 & 0,16 & 244,71 & 489,42 & 0,73 & 3,68 \\
\hline BH 2_50 & 1,63 & 0,38 & 0,75 & 0,92 & 0,18 & 666,44 & 1332,88 & 0,19 & 1,20 \\
\hline
\end{tabular}




\begin{tabular}{|c|c|c|c|c|c|c|c|c|c|}
\hline $\begin{array}{c}\text { Bacias } \\
\text { Hidrográficas }\end{array}$ & $\begin{array}{l}\text { Índice de } \\
\text { Forma }\end{array}$ & $\begin{array}{c}\text { Índice de } \\
\text { Circularidade }\end{array}$ & $\begin{array}{l}\text { Densidade } \\
\text { de } \\
\text { Drenagem }\end{array}$ & $\begin{array}{c}\text { Densidade } \\
\text { Hidrográfica }\end{array}$ & $\begin{array}{c}\text { Relação de } \\
\text { Relevo }\end{array}$ & $\begin{array}{l}\text { Extensão do } \\
\text { percurso } \\
\text { superficial }\end{array}$ & $\begin{array}{l}\text { Coeficiente de } \\
\text { manutenção }\end{array}$ & $\begin{array}{l}\text { Índice de } \\
\text { Rugosidade }\end{array}$ & $\begin{array}{c}\text { Textura } \\
\text { Topográfica }\end{array}$ \\
\hline BH 2_51 & 1,44 & 0,49 & 1,36 & 1,10 & 0,22 & 367,59 & 735,17 & 0,47 & 2,34 \\
\hline BH 2_53 & 1,16 & 0,75 & 2,19 & 3,84 & 0,19 & 228,05 & 456,10 & 0,37 & 3,98 \\
\hline BH 2_54 & 1,41 & 0,50 & 2,24 & 2,30 & 0,16 & 222,80 & 445,60 & 0,49 & 4,08 \\
\hline BH 2_55 & 1,28 & 0,61 & 1,31 & 1,79 & 0,19 & 382,18 & 764,37 & 0,38 & 2,24 \\
\hline BH 2_56 & 1,16 & 0,75 & 2,63 & 6,29 & 0,07 & 190,29 & 380,57 & 0,14 & 4,87 \\
\hline BH 2_58 & 1,61 & 0,39 & 0,73 & 1,22 & 0,05 & 683,86 & 1367,73 & 0,04 & 1,17 \\
\hline BH 2_59 & 1,53 & 0,43 & 0,94 & 0,90 & 0,04 & 532,17 & 1064,33 & 0,05 & 1,55 \\
\hline BH 2_60 & 1,58 & 0,40 & 0,49 & 0,55 & 0,05 & 1014,39 & 2028,79 & 0,04 & 0,75 \\
\hline BH 2_61 & 1,37 & 0,53 & 1,41 & 2,41 & 0,16 & 354,55 & 709,09 & 0,30 & 2,43 \\
\hline BH 2_62 & 1,20 & 0,70 & 2,38 & 4,44 & 0,09 & 209,81 & 419,61 & 0,18 & 4,37 \\
\hline BH 2_63 & 1,28 & 0,61 & 0,81 & 1,15 & 0,07 & 617,61 & 1235,21 & 0,07 & 1,31 \\
\hline BH 2_69 & 2,06 & 0,24 & 1,18 & 0,93 & 0,09 & 422,16 & 844,33 & 0,31 & 2,00 \\
\hline BH 2_70 & 1,27 & 0,62 & 1,85 & 1,27 & 0,09 & 269,57 & 539,15 & 0,57 & 3,30 \\
\hline BH 2_71 & 1,19 & 0,70 & 1,31 & 1,85 & 0,05 & 380,61 & 761,22 & 0,09 & 2,25 \\
\hline BH 2_72 & 1,25 & 0,64 & 1,56 & 1,09 & 0,08 & 319,62 & 639,24 & 0,48 & 2,73 \\
\hline BH 2_73 & 3,12 & 0,10 & 0,14 & 0,12 & 0,06 & 3554,87 & 7109,74 & 0,03 & 0,19 \\
\hline BH 2_74 & 1,94 & 0,27 & 0,86 & 0,82 & 0,23 & 580,85 & 1161,69 & 0,32 & 1,40 \\
\hline BH 2_75 & 1,46 & 0,47 & 2,56 & 3,77 & 0,30 & 195,44 & 390,87 & 0,84 & 4,73 \\
\hline
\end{tabular}




\begin{tabular}{|c|c|c|c|c|c|c|c|c|c|}
\hline $\begin{array}{c}\text { Bacias } \\
\text { Hidrográficas }\end{array}$ & $\begin{array}{l}\text { Índice de } \\
\text { Forma }\end{array}$ & $\begin{array}{c}\text { Índice de } \\
\text { Circularidade }\end{array}$ & $\begin{array}{c}\text { Densidade } \\
\text { de } \\
\text { Drenagem }\end{array}$ & $\begin{array}{l}\text { Densidade } \\
\text { Hidrográfica }\end{array}$ & $\begin{array}{c}\text { Relação de } \\
\text { Relevo }\end{array}$ & $\begin{array}{c}\text { Extensão do } \\
\text { percurso } \\
\text { superficial }\end{array}$ & $\begin{array}{l}\text { Coeficiente de } \\
\text { manutenção }\end{array}$ & $\begin{array}{c}\text { Índice de } \\
\text { Rugosidade }\end{array}$ & $\begin{array}{c}\text { Textura } \\
\text { Topográfica }\end{array}$ \\
\hline BH 2_76 & 1,22 & 0,67 & 1,96 & 1,48 & 0,18 & 255,44 & 510,87 & 1,01 & 3,51 \\
\hline BH 2_77 & 1,36 & 0,54 & 1,41 & 1,78 & 0,08 & 354,83 & 709,66 & 0,13 & 2,43 \\
\hline BH 2_78 & 1,33 & 0,56 & 1,77 & 2,50 & 0,06 & 282,15 & 564,30 & 0,12 & 3,14 \\
\hline BH 2_79 & 1,29 & 0,60 & 1,09 & 1,90 & 0,07 & 458,18 & 916,37 & 0,08 & 1,83 \\
\hline BH 2_80 & 1,33 & 0,57 & 1,77 & 2,73 & 0,04 & 282,58 & 565,17 & 0,14 & 3,13 \\
\hline BH 2_81 & 1,46 & 0,47 & 1,33 & 1,21 & 0,04 & 376,69 & 753,39 & 0,10 & 2,27 \\
\hline BH 2_82 & 1,51 & 0,44 & 1,00 & 1,30 & 0,06 & 500,16 & 1000,32 & 0,08 & 1,66 \\
\hline BH 2_83 & 1,32 & 0,57 & 0,86 & 0,84 & 0,04 & 578,21 & 1156,43 & 0,07 & 1,41 \\
\hline BH 2_84 & 1,44 & 0,48 & 0,80 & 1,50 & 0,06 & 623,85 & 1247,69 & 0,06 & 1,30 \\
\hline BH 2_85 & 1,19 & 0,71 & 2,47 & 3,47 & 0,04 & 202,31 & 404,62 & 0,20 & 4,55 \\
\hline BH 2_86 & 1,21 & 0,68 & 2,14 & 2,75 & 0,05 & 233,76 & 467,52 & 0,16 & 3,87 \\
\hline BH 2_87 & 1,16 & 0,74 & 2,72 & 5,05 & 0,08 & 183,49 & 366,98 & 0,18 & 5,07 \\
\hline BH 2_88 & 1,30 & 0,60 & 1,44 & 1,65 & 0,03 & 348,02 & 696,04 & 0,11 & 2,48 \\
\hline BH 2_89 & 1,17 & 0,73 & 3,14 & 5,25 & 0,11 & 159,20 & 318,39 & 0,30 & 5,94 \\
\hline BH 2_90 & 1,32 & 0,57 & 1,95 & 2,13 & 0,04 & 256,17 & 512,34 & 0,18 & 3,50 \\
\hline BH 2_91 & 1,34 & 0,56 & 1,42 & 1,70 & 0,06 & 351,15 & 702,30 & 0,20 & 2,46 \\
\hline BH 2_92 & 1,43 & 0,49 & 1,25 & 0,96 & 0,07 & 399,33 & 798,67 & 0,49 & 2,13 \\
\hline BH 2_93 & 1,31 & 0,58 & 0,65 & 0,45 & 0,04 & 768,31 & 1536,62 & 0,06 & 1,03 \\
\hline BH 2_94 & 1,51 & 0,44 & 0,87 & 0,81 & 0,08 & 576,12 & 1152,24 & 0,16 & 1,42 \\
\hline BH 2_95 & 1,35 & 0,55 & 1,23 & 0,82 & 0,03 & 406,74 & 813,48 & 0,10 & 2,09 \\
\hline BH 2_96 & 1,21 & 0,69 & 1,34 & 1,14 & 0,03 & 374,02 & 748,05 & 0,09 & 2,29 \\
\hline BH 2_97 & 1,30 & 0,59 & 0,67 & 0,77 & 0,04 & 741,08 & 1482,17 & 0,05 & 1,07 \\
\hline BH 2_98 & 1,35 & 0,55 & 1,02 & 0,55 & 0,02 & 491,77 & 983,54 & 0,07 & 1,69 \\
\hline BH 2_99 & 1,35 & 0,55 & 1,77 & 2,60 & 0,06 & 283,06 & 566,13 & 0,13 & 3,13 \\
\hline BH 2_100 & 1,45 & 0,48 & 1,26 & 2,30 & 0,29 & 396,71 & 793,42 & 0,29 & 2,15 \\
\hline
\end{tabular}


APÊNDICE D - Percentual de área dos atributos do meio físico das bacias hidrográficas de $2^{\mathrm{a}}$ ordem

\begin{tabular}{|c|c|c|c|c|c|c|c|c|}
\hline \multicolumn{9}{|c|}{ Materiais Inconsolidados (apenas aspecto textural) (\%) } \\
\hline $\begin{array}{c}\text { Bacias } \\
\text { Hidrográficas }\end{array}$ & $\begin{array}{l}\text { Área } \\
\left(\mathrm{km}^{2}\right)\end{array}$ & Areia & Silte & Silte e Rocha & $\begin{array}{l}\text { Distribuída } \\
\text { (Areia) }\end{array}$ & $\begin{array}{l}\text { Distribuída } \\
\text { (Silte) }\end{array}$ & $\begin{array}{c}\text { Distribuída } \\
\text { (Silte/Argila) }\end{array}$ & $\begin{array}{c}\text { Distribuída } \\
\text { (Argila/Silte/Areia) }\end{array}$ \\
\hline BH 2_1 & 5,79 & 63,96 & 21,58 & 4,10 & 6,99 & 0,00 & 2,06 & 1,31 \\
\hline BH 2_2 & 13,63 & 35,62 & 26,75 & 0,00 & 35,92 & 0,00 & 1,71 & 0,00 \\
\hline BH 2_3 & 10,67 & 51,21 & 28,23 & 18,57 & 0,00 & 0,00 & 1,99 & 0,00 \\
\hline BH 2_4 & 16,57 & 36,93 & 37,33 & 2,80 & 14,97 & 0,00 & 7,97 & 0,00 \\
\hline BH 2_5 & 10,80 & 67,74 & 25,61 & 1,66 & 0,00 & 0,00 & 4,99 & 0,00 \\
\hline BH 2_6 & 6,52 & 36,13 & 45,82 & 0,00 & 16,72 & 0,00 & 1,33 & 0,00 \\
\hline BH 2_7 & 4,65 & 63,92 & 30,25 & 3,90 & 0,19 & 0,00 & 1,74 & 0,00 \\
\hline BH 2_8 & 4,18 & 37,77 & 25,95 & 0,00 & 35,69 & 0,00 & 0,59 & 0,00 \\
\hline BH 2_9 & 5,67 & 47,50 & 47,01 & 5,49 & 0,00 & 0,00 & 0,00 & 0,00 \\
\hline BH 2_10 & 6,24 & 47,20 & 24,13 & 2,74 & 17,81 & 4,67 & 3,45 & 0,00 \\
\hline BH 2_11 & 1,60 & 38,91 & 61,09 & 0,00 & 0,00 & 0,00 & 0,00 & 0,00 \\
\hline BH 2_12 & 0,38 & 0,00 & 0,00 & 0,00 & 100,00 & 0,00 & 0,00 & 0,00 \\
\hline BH 2_13 & 0,91 & 30,52 & 69,48 & 0,00 & 0,00 & 0,00 & 0,00 & 0,00 \\
\hline BH 2_14 & 0,94 & 51,56 & 12,13 & 4,25 & 32,06 & 0,00 & 0,00 & 0,00 \\
\hline BH 2_15 & 3,37 & 47,48 & 33,20 & 0,00 & 0,00 & 0,00 & 6,92 & 12,40 \\
\hline BH 2_16 & 6,36 & 47,17 & 24,17 & 0,00 & 28,13 & 0,53 & 0,00 & 0,00 \\
\hline BH 2_17 & 9,30 & 20,09 & 5,99 & 0,00 & 66,13 & 0,00 & 4,32 & 3,47 \\
\hline BH 2_18 & 3,77 & 29,08 & 70,57 & 0,00 & 0,00 & 0,00 & 0,35 & 0,00 \\
\hline BH 2_19 & 7,91 & 10,50 & 0,00 & 0,00 & 89,28 & 0,00 & 0,22 & 0,00 \\
\hline BH 2_20 & 4,31 & 19,84 & 8,62 & 0,00 & 0,15 & 0,00 & 0,00 & 71,39 \\
\hline BH 2_21 & 11,82 & 19,24 & 11,06 & 0,00 & 66,59 & 0,00 & 3,11 & 0,00 \\
\hline BH 2_22 & 2,46 & 26,62 & 73,38 & 0,00 & 0,00 & 0,00 & 0,00 & 0,00 \\
\hline BH 2_23 & 1,05 & 0,00 & 0,00 & 0,00 & 100,00 & 0,00 & 0,00 & 0,00 \\
\hline BH 2_24 & 5,14 & 0,00 & 0,00 & 0,00 & 100,00 & 0,00 & 0,00 & 0,00 \\
\hline BH 2_25 & 2,71 & 15,96 & 26,47 & 7,67 & 0,00 & 0,00 & 49,90 & 0,00 \\
\hline BH 2_26 & 2,22 & 0,00 & 0,00 & 0,00 & 100,00 & 0,00 & 0,00 & 0,00 \\
\hline
\end{tabular}




\begin{tabular}{c|c|c|c|c|c|c|c|c}
\hline \multicolumn{8}{c}{ Materiais Inconsolidados (apenas aspecto textural) (\%) } \\
\hline $\begin{array}{c}\text { Bacias } \\
\text { Hidrográficas }\end{array}$ & $\begin{array}{c}\text { Área } \\
\left(\mathrm{km}^{2}\right)\end{array}$ & Areia & Silte & Silte e Rocha & $\begin{array}{c}\text { Distribuída } \\
\text { (Areia) }\end{array}$ & $\begin{array}{c}\text { Distribuída } \\
\text { (Silte) }\end{array}$ & $\begin{array}{c}\text { Distribuída } \\
\text { (Silte/Argila) }\end{array}$ & $\begin{array}{c}\text { Distribuída } \\
\text { (Argila/Silte/Areia) }\end{array}$ \\
\hline BH 2_27 & 7,29 & 31,23 & 13,22 & 0,00 & 52,95 & 0,00 & 1,18 & 1,42 \\
\hline BH 2_28 & 3,25 & 62,81 & 12,84 & 0,00 & 0,00 & 0,00 & 24,35 & 0,00 \\
\hline BH 2_29 & 1,64 & 0,00 & 0,00 & 0,00 & 100,00 & 0,00 & 0,00 & 0,00 \\
\hline BH 2_30 & 15,09 & 10,70 & 0,00 & 0,00 & 86,52 & 0,00 & 2,78 & 0,00 \\
\hline BH 2_31 & 5,10 & 0,00 & 0,00 & 0,00 & 96,40 & 0,00 & 3,60 & 0,00 \\
\hline BH 2_32 & 4,45 & 0,00 & 7,63 & 0,00 & 92,37 & 0,00 & 0,00 & 0,00 \\
\hline BH 2_33 & 3,64 & 0,00 & 0,00 & 0,00 & 100,00 & 0,00 & 0,00 & \\
\hline BH 2_34 & 16,44 & 47,36 & 9,04 & 0,00 & 18,74 & 4,08 & 0,00 & \\
\hline
\end{tabular}




\begin{tabular}{|c|c|c|c|c|c|c|c|}
\hline \multicolumn{8}{|c|}{ Substrato Rochoso (\%) } \\
\hline $\begin{array}{c}\text { Bacias } \\
\text { Hidrográficas }\end{array}$ & Área $\left(\mathrm{km}^{2}\right)$ & Coberturas Quaternárias & Gnaisse & Xisto & Quartzito & Milonito & Xisto/Quartzito \\
\hline BH 2_1 & 5,79 & 4,63 & 6,99 & 13,64 & 35,83 & 11,21 & 27,70 \\
\hline BH 2_2 & 13,63 & 4,57 & 4,52 & 23,99 & 34,32 & 1,20 & 31,40 \\
\hline BH 2_3 & 10,67 & 5,76 & 0,00 & 33,20 & 50,13 & 10,36 & 0,55 \\
\hline BH 2_4 & 16,57 & 8,50 & 5,11 & 15,06 & 35,91 & 15,89 & 19,53 \\
\hline BH 2_5 & 10,80 & 4,48 & 0,00 & 15,69 & 63,85 & 10,75 & 5,23 \\
\hline BH 2_6 & 6,52 & 1,65 & 0,00 & 36,22 & 36,13 & 9,28 & 16,72 \\
\hline BH 2_7 & 4,65 & 2,43 & 0,00 & 7,68 & 41,57 & 16,97 & 31,35 \\
\hline BH 2_8 & 4,18 & 2,07 & 7,90 & 16,02 & 22,58 & 10,75 & 40,68 \\
\hline BH 2_9 & 5,67 & 0,00 & 0,00 & 3,45 & 50,61 & 35,65 & 10,29 \\
\hline BH 2_10 & 6,24 & 2,12 & 12,77 & 9,95 & 47,36 & 10,00 & 17,80 \\
\hline BH 2_11 & 1,60 & 0,00 & 0,00 & 16,94 & 36,29 & 31,75 & 15,02 \\
\hline BH 2_12 & 0,38 & 0,00 & 0,00 & 0,00 & 0,00 & 0,00 & 100,00 \\
\hline BH 2_13 & 0,91 & 0,00 & 0,00 & 0,00 & 30,52 & 42,21 & 27,27 \\
\hline BH 2_14 & 0,94 & 0,00 & 1,16 & 16,11 & 6,32 & 0,27 & 76,14 \\
\hline BH 2_15 & 3,37 & 7,02 & 12,40 & 23,92 & 46,89 & 9,77 & 0,00 \\
\hline BH 2_16 & 6,36 & 0,00 & 28,67 & 10,70 & 20,41 & 0,00 & 40,22 \\
\hline BH 2_17 & 9,30 & 4,03 & 62,56 & 5,64 & 18,67 & 0,90 & 8,20 \\
\hline BH 2_18 & 3,77 & 0,00 & 0,00 & 54,91 & 28,51 & 15,67 & 0,91 \\
\hline BH 2_19 & 7,91 & 0,00 & 15,00 & 0,00 & 0,39 & 0,00 & 84,61 \\
\hline BH 2_20 & 4,31 & 0,00 & 52,57 & 8,62 & 18,21 & 0,00 & 20,60 \\
\hline BH 2_21 & 11,82 & 0,00 & 59,52 & 0,00 & 19,24 & 0,00 & 21,24 \\
\hline BH 2_22 & 2,46 & 0,00 & 0,00 & 9,91 & 37,27 & 52,82 & 0,00 \\
\hline BH 2_23 & 1,05 & 0,00 & 0,00 & 0,00 & 0,00 & 0,00 & 100,00 \\
\hline BH 2_24 & 5,14 & 0,00 & 53,45 & 0,00 & 0,00 & 0,00 & 46,55 \\
\hline BH 2_25 & 2,71 & 40,05 & 0,00 & 7,67 & 4,61 & 47,67 & 0,00 \\
\hline BH 2_26 & 2,22 & 0,00 & 100,00 & 0,00 & 0,00 & 0,00 & 0,00 \\
\hline
\end{tabular}




\begin{tabular}{|c|c|c|c|c|c|c|c|}
\hline \multicolumn{8}{|c|}{ Substrato Rochoso (\%) } \\
\hline $\begin{array}{c}\text { Bacias } \\
\text { Hidrográficas }\end{array}$ & Área $\left(\mathrm{km}^{2}\right)$ & Coberturas Quaternárias & Gnaisse & Xisto & Quartzito & Milonito & Xisto/Quartzito \\
\hline BH 2_27 & 7,29 & 0,00 & 15,30 & 6,25 & 17,31 & 0,00 & 61,14 \\
\hline BH 2_28 & 3,25 & 0,00 & 0,00 & 12,65 & 30,21 & 0,20 & 56,94 \\
\hline BH 2_29 & 1,64 & 0,00 & 68,82 & 0,00 & 0,00 & 0,00 & 31,18 \\
\hline BH 2_30 & 15,09 & 0,00 & 45,79 & 0,00 & 7,22 & 0,00 & 46,99 \\
\hline BH 2_31 & 5,10 & 0,00 & 51,92 & 0,00 & 0,00 & 0,00 & 48,08 \\
\hline BH 2_32 & 4,45 & 0,00 & 76,85 & 0,00 & 0,00 & 0,00 & 23,15 \\
\hline BH 2_33 & 3,64 & 0,00 & 0,00 & 0,00 & 0,00 & 0,00 & 100,00 \\
\hline BH 2_34 & 16,44 & 0,00 & 22,04 & 0,00 & 24,18 & 0,00 & 53,78 \\
\hline
\end{tabular}




\begin{tabular}{|c|c|c|c|c|c|c|c|c|c|}
\hline \multicolumn{10}{|c|}{ Declividade (\%) } \\
\hline Bacias Hidrográficas & $\begin{array}{c}\text { Área } \\
\left(\mathrm{km}^{2}\right)\end{array}$ & $0-2 \%$ & $2-5 \%$ & $5-10 \%$ & $10-15 \%$ & $15-20 \%$ & $20-30 \%$ & $30-45 \%$ & $>45 \%$ \\
\hline BH 2_1 & 5,79 & 5,06 & 14,47 & 16,57 & 12,64 & 9,98 & 17,50 & 15,73 & 8,05 \\
\hline BH 2_2 & 13,63 & 4,59 & 12,36 & 19,71 & 16,80 & 10,36 & 13,36 & 12,58 & 10,24 \\
\hline BH 2_3 & 10,67 & 1,08 & 3,28 & 10,09 & 11,77 & 10,26 & 18,88 & 21,17 & 23,47 \\
\hline BH 2_4 & 16,57 & 2,42 & 9,13 & 17,34 & 14,41 & 11,00 & 15,32 & 15,38 & 15,00 \\
\hline BH 2_5 & 10,80 & 3,64 & 11,61 & 18,67 & 13,91 & 10,35 & 14,93 & 14,62 & 12,27 \\
\hline BH 2_6 & 6,52 & 2,92 & 8,53 & 16,27 & 9,77 & 8,93 & 15,27 & 16,51 & 21,80 \\
\hline BH 2_7 & 4,65 & 1,08 & 3,95 & 8,94 & 10,16 & 9,93 & 18,58 & 24,56 & 22,80 \\
\hline BH 2_8 & 4,18 & 6,81 & 13,06 & 23,64 & 16,91 & 10,51 & 9,92 & 8,57 & 10,58 \\
\hline BH 2_9 & 5,67 & 1,08 & 6,70 & 15,90 & 17,98 & 12,62 & 15,92 & 15,80 & 14,00 \\
\hline BH 2_10 & 6,24 & 2,84 & 12,56 & 19,58 & 14,07 & 9,73 & 13,42 & 13,50 & 14,30 \\
\hline BH 2_11 & 1,60 & 1,30 & 2,31 & 9,49 & 12,35 & 10,24 & 14,46 & 20,41 & 29,44 \\
\hline BH 2_12 & 0,38 & 2,12 & 3,88 & 20,64 & 26,54 & 24,08 & 16,81 & 5,25 & 0,68 \\
\hline BH 2_13 & 0,91 & 0,67 & 1,01 & 5,60 & 10,84 & 10,12 & 19,58 & 23,78 & 28,40 \\
\hline BH 2_14 & 0,94 & 2,45 & 9,37 & 14,26 & 13,41 & 14,18 & 21,67 & 14,44 & 10,22 \\
\hline BH 2_15 & 3,37 & 1,89 & 8,69 & 16,91 & 15,46 & 10,76 & 14,40 & 15,00 & 16,89 \\
\hline BH 2_16 & 6,36 & 5,88 & 16,83 & 21,75 & 12,02 & 8,15 & 12,94 & 13,60 & 8,83 \\
\hline BH 2_17 & 9,30 & 8,06 & 20,43 & 30,41 & 15,00 & 6,74 & 7,53 & 7,88 & 3,95 \\
\hline BH 2_18 & 3,77 & 1,62 & 5,20 & 13,28 & 11,81 & 10,19 & 16,90 & 18,82 & 22,18 \\
\hline BH 2_19 & 7,91 & 8,62 & 24,28 & 32,60 & 18,20 & 8,35 & 5,67 & 2,07 & 0,21 \\
\hline BH 2_20 & 4,31 & 26,94 & 16,54 & 17,61 & 12,86 & 8,22 & 10,41 & 6,17 & 1,25 \\
\hline BH 2_21 & 11,82 & 6,23 & 19,59 & 32,45 & 17,10 & 7,82 & 7,86 & 6,23 & 2,72 \\
\hline BH 2_22 & 2,46 & 4,19 & 22,68 & 27,64 & 19,45 & 6,93 & 6,84 & 6,91 & 5,36 \\
\hline BH 2_23 & 1,05 & 4,47 & 19,70 & 35,97 & 24,46 & 9,67 & 4,49 & 1,10 & 0,14 \\
\hline BH 2_24 & 5,14 & 11,27 & 26,78 & 33,53 & 16,78 & 5,88 & 4,24 & 1,41 & 0,11 \\
\hline BH 2_25 & 2,71 & 11,78 & 19,65 & 29,14 & 15,12 & 9,38 & 8,90 & 4,30 & 1,73 \\
\hline BH 2_26 & 2,22 & 18,53 & 23,67 & 39,97 & 13,27 & 3,45 & 1,11 & 0,00 & 0,00 \\
\hline
\end{tabular}




\begin{tabular}{|c|c|c|c|c|c|c|c|c|c|}
\hline \multicolumn{10}{|c|}{ Declividade (\%) } \\
\hline Bacias Hidrográficas & $\begin{array}{c}\text { Área } \\
\left(\mathrm{km}^{2}\right)\end{array}$ & $0-2 \%$ & $2-5 \%$ & $5-10 \%$ & $10-15 \%$ & $15-20 \%$ & $20-30 \%$ & $30-45 \%$ & $>45 \%$ \\
\hline BH 2_27 & 7,29 & 7,08 & 15,88 & 20,00 & 15,50 & 8,79 & 9,28 & 10,08 & 13,39 \\
\hline BH 2_28 & 3,25 & 10,49 & 20,66 & 18,88 & 13,08 & 10,16 & 12,56 & 9,04 & 5,13 \\
\hline BH 2_29 & 1,64 & 25,96 & 25,52 & 32,77 & 11,24 & 2,77 & 1,39 & 0,35 & 0,00 \\
\hline BH 2_30 & 15,09 & 14,72 & 32,65 & 29,76 & 10,00 & 4,60 & 4,86 & 2,99 & 0,42 \\
\hline BH 2_31 & 5,10 & 14,03 & 25,45 & 38,77 & 13,80 & 4,91 & 2,40 & 0,50 & 0,14 \\
\hline BH 2_32 & 4,45 & 21,80 & 26,80 & 36,60 & 9,54 & 2,21 & 2,24 & 0,76 & 0,05 \\
\hline BH 2_33 & 3,64 & 7,62 & 33,78 & 33,30 & 15,27 & 6,52 & 3,11 & 0,40 & 0,00 \\
\hline BH 2_34 & 16,44 & 29,05 & 15,42 & 17,99 & 9,62 & 6,16 & 8,01 & 8,25 & 5,50 \\
\hline
\end{tabular}




\section{APÊNDICE E - Índices morfométricos das bacias hidrográficas de $3^{\text {a }}$ ordem}

\begin{tabular}{|c|c|c|c|c|c|c|c|c|c|}
\hline $\begin{array}{c}\text { Bacias } \\
\text { Hidrográficas }\end{array}$ & $\begin{array}{l}\text { Índice de } \\
\text { Forma }\end{array}$ & $\begin{array}{c}\text { Indice de } \\
\text { Circularidade }\end{array}$ & $\begin{array}{c}\text { Densidade } \\
\text { de } \\
\text { Drenagem }\end{array}$ & $\begin{array}{l}\text { Densidade } \\
\text { Hidrográfica }\end{array}$ & $\begin{array}{l}\text { Relação de } \\
\text { Relevo }\end{array}$ & $\begin{array}{l}\text { Extensão do } \\
\text { percurso superficial }\end{array}$ & $\begin{array}{l}\text { Coeficiente } \\
\text { de } \\
\text { Manutenção }\end{array}$ & $\begin{array}{l}\text { Indice de } \\
\text { Rugosidade }\end{array}$ & $\begin{array}{c}\text { Textura } \\
\text { Topográfica }\end{array}$ \\
\hline BH 3_1 & 1,51 & 0,44 & 2,23 & 1,79 & 0,06 & 224,18 & 448,35 & 0,76 & 4,06 \\
\hline BH 3_2 & 1,40 & 0,51 & 2,03 & 1,63 & 0,11 & 246,83 & 493,66 & 0,99 & 3,64 \\
\hline BH 3_3 & 1,46 & 0,47 & 1,88 & 2,44 & 0,14 & 265,37 & 530,74 & 0,44 & 3,36 \\
\hline BH 3_4 & 1,26 & 0,62 & 1,63 & 1,21 & 0,13 & 306,18 & 612,35 & 0,61 & 2,87 \\
\hline BH 3_5 & 1,57 & 0,41 & 2,77 & 2,84 & 0,06 & 180,45 & 360,91 & 0,82 & 5,17 \\
\hline BH 3_6 & 1,54 & 0,42 & 2,08 & 2,01 & 0,09 & 239,95 & 479,89 & 1,09 & 3,76 \\
\hline BH 3_7 & 1,46 & 0,47 & 1,68 & 1,81 & 0,07 & 298,45 & 596,90 & 0,83 & 2,95 \\
\hline BH 3_8 & 1,28 & 0,61 & 1,46 & 2,04 & 0,25 & 341,71 & 683,41 & 0,62 & 2,53 \\
\hline BH 3_9 & 1,21 & 0,69 & 2,09 & 1,65 & 0,13 & 239,25 & 478,49 & 0,84 & 3,77 \\
\hline BH 3_10 & 1,33 & 0,57 & 1,96 & 1,35 & 0,12 & 254,97 & 509,94 & 1,10 & 3,51 \\
\hline BH 3_11 & 1,27 & 0,62 & 2,52 & 2,76 & 0,24 & 198,33 & 396,66 & 1,34 & 4,65 \\
\hline BH 3_12 & 1,25 & 0,64 & 2,58 & 2,48 & 0,13 & 193,95 & 387,89 & 1,08 & 4,77 \\
\hline BH 3_13 & 1,31 & 0,58 & 2,12 & 2,81 & 0,22 & 236,09 & 472,18 & 1,12 & 3,83 \\
\hline BH 3_14 & 1,57 & 0,40 & 2,74 & 4,66 & 0,39 & 182,70 & 365,39 & 1,39 & 5,10 \\
\hline BH 3_15 & 1,27 & 0,62 & 1,81 & 1,65 & 0,17 & 276,16 & 552,31 & 0,91 & 3,21 \\
\hline BH 3_16 & 1,30 & 0,59 & 2,88 & 4,05 & 0,19 & 173,49 & 346,99 & 0,88 & 5,40 \\
\hline BH 3_17 & 1,37 & 0,54 & 3,73 & 4,56 & 0,10 & 134,07 & 268,13 & 1,62 & 7,20 \\
\hline BH 3_18 & 1,44 & 0,48 & 2,71 & 2,99 & 0,11 & 184,82 & 369,64 & 1,20 & 5,03 \\
\hline BH 3_19 & 1,44 & 0,48 & 1,75 & 3,01 & 0,18 & 285,28 & 570,57 & 0,55 & 3,10 \\
\hline BH 3_20 & 1,36 & 0,54 & 2,11 & 2,10 & 0,08 & 236,46 & 472,92 & 0,69 & 3,82 \\
\hline BH 3_21 & 1,37 & 0,53 & 2,10 & 1,84 & 0,08 & 237,60 & 475,20 & 1,22 & 3,80 \\
\hline BH 3_22 & 1,31 & 0,58 & 1,53 & 1,24 & 0,08 & 327,68 & 655,36 & 0,52 & 2,66 \\
\hline BH 3_23 & 1,60 & 0,39 & 2,05 & 1,56 & 0,09 & 243,53 & 487,05 & 1,18 & 3,70 \\
\hline BH 3_24 & 1,88 & 0,28 & 1,01 & 0,93 & 0,08 & 494,23 & 988,46 & 0,35 & 1,68 \\
\hline BH 3_25 & 1,47 & 0,47 & 2,43 & 2,12 & 0,14 & 205,97 & 411,95 & 0,86 & 4,46 \\
\hline BH 3_26 & 1,41 & 0,50 & 2,84 & 3,10 & 0,08 & 176,17 & 352,33 & 1,02 & 5,31 \\
\hline
\end{tabular}




\begin{tabular}{|c|c|c|c|c|c|c|c|c|c|}
\hline $\begin{array}{c}\text { Bacias } \\
\text { Hidrográficas }\end{array}$ & $\begin{array}{l}\text { Índice de } \\
\text { Forma }\end{array}$ & $\begin{array}{c}\text { Índice de } \\
\text { Circularidade }\end{array}$ & $\begin{array}{c}\text { Densidade } \\
\text { de } \\
\text { Drenagem }\end{array}$ & $\begin{array}{l}\text { Densidade } \\
\text { Hidrográfica }\end{array}$ & $\begin{array}{l}\text { Relação de } \\
\text { Relevo }\end{array}$ & $\begin{array}{l}\text { Extensão do } \\
\text { percurso superficial }\end{array}$ & $\begin{array}{l}\text { Coeficiente } \\
\text { de } \\
\text { Manutenção }\end{array}$ & $\begin{array}{c}\text { Índice de } \\
\text { Rugosidade }\end{array}$ & $\begin{array}{c}\text { Textura } \\
\text { Topográfica }\end{array}$ \\
\hline BH 3_27 & 1,44 & 0,48 & 1,91 & 2,20 & 0,07 & 261,48 & 522,95 & 0,69 & 3,42 \\
\hline BH 3_29 & 1,38 & 0,53 & 1,88 & 2,18 & 0,02 & 266,05 & 532,11 & 0,14 & 3,35 \\
\hline BH 3_30 & 1,45 & 0,47 & 1,90 & 1,65 & 0,03 & 263,06 & 526,13 & 0,37 & 3,39 \\
\hline BH 3_31 & 1,59 & 0,39 & 1,22 & 0,69 & 0,02 & 409,08 & 818,17 & 0,12 & 2,07 \\
\hline BH 3_32 & 1,95 & 0,26 & 1,01 & 1,67 & 0,08 & 496,96 & 993,91 & 0,14 & 1,67 \\
\hline BH 3_34 & 1,62 & 0,38 & 2,26 & 2,12 & 0,05 & 221,64 & 443,28 & 1,02 & 4,11 \\
\hline BH 3_35 & 1,59 & 0,40 & 1,74 & 1,40 & 0,11 & 286,84 & 573,67 & 0,91 & 3,08 \\
\hline BH 3_36 & 1,31 & 0,58 & 1,28 & 1,18 & 0,02 & 391,14 & 782,28 & 0,09 & 2,18 \\
\hline BH 3_37 & 1,28 & 0,61 & 2,15 & 2,76 & 0,11 & 232,66 & 465,32 & 0,45 & 3,89 \\
\hline
\end{tabular}




\section{APÊNDICE F - Percentual de área dos atributos do meio físico das bacias hidrográficas de $3^{\text {a }}$ ordem}

\begin{tabular}{|c|c|c|c|c|c|c|c|c|}
\hline \multicolumn{9}{|c|}{ Materiais Inconsolidados (apenas aspecto textural) (\%) } \\
\hline $\begin{array}{c}\text { Bacias } \\
\text { Hidrográficas }\end{array}$ & $\begin{array}{l}\text { Área } \\
\left(\mathrm{km}^{2}\right)\end{array}$ & Areia & Silte & Silte e Rocha & Distribuída (Areia) & Distribuída (Silte) & Distribuída (Silte/Argila) & $\begin{array}{c}\text { Distribuída } \\
\text { (Argila/Silte/Areia) }\end{array}$ \\
\hline BH 3_1 & 20,10 & 10,62 & 17,32 & 0,00 & 46,49 & 18,67 & 6,90 & 0,00 \\
\hline BH 3_2 & 43,90 & 18,81 & 62,11 & 13,28 & 3,27 & 0,00 & 1,99 & 0,54 \\
\hline BH 3_3 & 34,42 & 4,45 & 24,80 & 0,00 & 61,69 & 0,00 & 6,60 & 2,46 \\
\hline BH 3_4 & 5,93 & 78,18 & 21,82 & 0,00 & 0,00 & 0,00 & 0,00 & 0,00 \\
\hline BH 3_5 & 16,86 & 33,42 & 26,80 & 31,93 & 0,00 & 0,00 & 7,85 & 0,00 \\
\hline BH 3_6 & 3,64 & 80,31 & 13,17 & 6,52 & 0,00 & 0,00 & 0,00 & 0,00 \\
\hline BH 3_7 & 13,78 & 21,53 & 16,84 & 0,00 & 60,91 & 0,00 & 0,72 & 0,00 \\
\hline BH 3_8 & 13,92 & 52,64 & 28,46 & 7,41 & 11,49 & 0,00 & 0,00 & 0,00 \\
\hline BH 3_9 & 5,04 & 45,94 & 46,40 & 7,66 & 0,00 & 0,00 & 0,00 & 0,00 \\
\hline BH 3_10 & 2,35 & 83,63 & 0,00 & 0,00 & 13,23 & 0,00 & 3,14 & 0,00 \\
\hline BH 3_11 & 5,93 & 51,56 & 18,36 & 30,08 & 0,00 & 0,00 & 0,00 & 0,00 \\
\hline BH 3_12 & 2,45 & 10,64 & 23,40 & 47,33 & 0,00 & 0,00 & 18,63 & 0,00 \\
\hline BH 3_13 & 5,64 & 52,22 & 27,93 & 0,00 & 0,00 & 0,00 & 0,64 & 19,21 \\
\hline BH 3_14 & 10,61 & 43,19 & 56,81 & 0,00 & 0,00 & 0,00 & 0,00 & 0,00 \\
\hline BH 3_15 & 10,21 & 0,00 & 0,00 & 0,00 & 100,00 & 0,00 & 0,00 & 0,00 \\
\hline BH 3_16 & 5,07 & 0,00 & 0,00 & 0,00 & 100,00 & 0,00 & 0,00 & 0,00 \\
\hline BH 3_17 & 12,19 & 39,80 & 0,00 & 0,00 & 60,20 & 0,00 & 0,00 & 0,00 \\
\hline
\end{tabular}




\begin{tabular}{|c|c|c|c|c|c|c|c|}
\hline \multicolumn{8}{|c|}{ Substrato Rochoso (\%) } \\
\hline $\begin{array}{c}\text { Bacias } \\
\text { Hidrográficas }\end{array}$ & Área $\left(\mathrm{km}^{2}\right)$ & Coberturas Quaternárias & Gnaisse & Xisto & Quartzito & Milonito & Xisto/Quartzito \\
\hline BH 3_1 & 20,10 & 0,00 & 67,98 & 0,00 & 10,62 & 0,00 & 21,40 \\
\hline BH 3_2 & 43,90 & 1,08 & 0,10 & 45,24 & 17,87 & 18,27 & 17,44 \\
\hline BH 3_3 & 34,42 & 0,68 & 41,74 & 6,92 & 5,48 & 14,11 & 31,07 \\
\hline BH 3_4 & 5,93 & 0,00 & 0,00 & 19,90 & 78,18 & 1,92 & 0,00 \\
\hline BH 3_5 & 16,86 & 7,46 & 0,00 & 35,48 & 36,88 & 20,18 & 0,00 \\
\hline BH 3_6 & 3,64 & 0,00 & 0,00 & 17,49 & 80,32 & 2,19 & 0,00 \\
\hline BH 3_7 & 13,78 & 0,00 & 36,22 & 5,80 & 21,53 & 4,50 & 31,95 \\
\hline BH 3_8 & 13,92 & 0,80 & 8,36 & 19,60 & 40,79 & 9,70 & 20,75 \\
\hline BH 3_9 & 5,04 & 0,00 & 0,00 & 20,04 & 45,94 & 23,18 & 10,84 \\
\hline BH 3_10 & 2,35 & 0,00 & 0,00 & 0,00 & 42,23 & 0,00 & 57,77 \\
\hline BH 3_11 & 5,93 & 0,00 & 0,00 & 4,88 & 51,56 & 13,48 & 30,08 \\
\hline BH 3_12 & 2,45 & 19,58 & 0,00 & 22,63 & 10,64 & 47,15 & 0,00 \\
\hline BH 3_13 & 5,64 & 0,00 & 0,00 & 22,28 & 52,24 & 0,00 & 25,48 \\
\hline BH 3_14 & 10,61 & 0,00 & 0,00 & 56,81 & 43,19 & 0,00 & 0,00 \\
\hline BH 3_15 & 10,21 & 2,65 & 57,97 & 0,00 & 0,00 & 0,00 & 39,38 \\
\hline BH 3_16 & 5,07 & 0,00 & 96,28 & 0,00 & 0,00 & 0,00 & 3,72 \\
\hline BH 3_17 & 12,19 & 0,00 & 6,10 & 0,00 & 20,55 & 0,00 & 73,35 \\
\hline
\end{tabular}




\begin{tabular}{c|c|c|c|c|c|c|c|c|c}
\hline \multicolumn{7}{c}{ Declividade (\%) } \\
\hline $\begin{array}{c}\text { Bacias } \\
\text { Hidrográficas }\end{array}$ & $\begin{array}{c}\text { Área } \\
\left(\mathrm{km}^{2}\right)\end{array}$ & $0-2 \%$ & $2-5 \%$ & $5-10 \%$ & $10-15 \%$ & $15-20 \%$ & $20-30 \%$ & $30-45 \%$ & $>45 \%$ \\
\hline BH 3_1 & 20,10 & 9,25 & 12,29 & 23,74 & 17,03 & 10,57 & 12,80 & 10,10 \\
\hline BH 3_2 & 43,90 & 2,15 & 7,84 & 12,78 & 12,33 & 11,72 & 18,93 & 19,82 & 14,43 \\
\hline BH 3_3 & 34,42 & 7,33 & 21,00 & 31,48 & 17,80 & 8,91 & 7,30 & 4,16 & 2,02 \\
\hline BH 3_4 & 5,93 & 2,15 & 9,74 & 21,41 & 14,44 & 14,04 & 15,17 & 9,31 \\
\hline BH 3_5 & 16,86 & 2,08 & 10,75 & 20,27 & 12,14 & 8,61 & 13,99 & 16,55 & 13,74 \\
\hline BH 3_6 & 3,64 & 1,28 & 5,50 & 15,55 & 13,74 & 8,60 & 11,48 & 14,74 & 29,11 \\
\hline BH 3_7 & 13,78 & 10,63 & 17,83 & 25,11 & 14,43 & 8,28 & 11,12 & 8,67 \\
\hline BH 3_8 & 13,92 & 1,81 & 7,20 & 14,97 & 15,03 & 12,50 & 20,02 & 18,02 & 1,93 \\
\hline BH 3_9 & 5,04 & 0,39 & 2,40 & 9,61 & 13,32 & 11,89 & 21,86 & 20,42 & 20,45 \\
\hline BH 3_10 & 2,35 & 1,96 & 9,47 & 15,73 & 15,95 & 12,04 & 23,36 & 17,12 & 4,37 \\
\hline BH 3_11 & 5,93 & 0,86 & 4,56 & 10,84 & 11,55 & 10,21 & 20,65 & 23,56 & 17,77 \\
\hline BH 3_12 & 2,45 & 6,25 & 11,39 & 10,84 & 14,53 & 13,78 & 19,58 & 16,41 \\
\hline BH 3_13 & 5,64 & 1,69 & 5,88 & 12,18 & 11,67 & 10,82 & 20,00 & 20,59 & 17,22 \\
\hline BH 3_14 & 10,61 & 1,39 & 8,22 & 12,17 & 10,87 & 9,07 & 14,59 & 18,67 \\
\hline BH 3_15 & 10,21 & 10,01 & 28,41 & 31,83 & 15,18 & 7,07 & 4,90 & 2,17 \\
\hline BH 3_16 & 5,07 & 14,10 & 28,80 & 40,29 & 10,38 & 4,45 & 1,62 & 0,30 \\
\hline BH 3_17 & 12,19 & 7,32 & 16,77 & 28,16 & 19,64 & 9,47 & 10,23 & 6,73 \\
\hline
\end{tabular}





\section{APÊNDICE G - Índices morfométricos das bacias hidrográficas de $4^{\mathrm{a}}$ ordem}

\begin{tabular}{|c|c|c|c|c|c|c|c|c|c|}
\hline $\begin{array}{c}\text { Bacias } \\
\text { Hidrográficas }\end{array}$ & $\begin{array}{l}\text { Indice } \\
\text { de } \\
\text { Forma }\end{array}$ & $\begin{array}{c}\text { Índice de } \\
\text { Circularidade }\end{array}$ & $\begin{array}{l}\text { Densidade de } \\
\text { Drenagem }\end{array}$ & $\begin{array}{l}\text { Densidade } \\
\text { Hidrográfica }\end{array}$ & $\begin{array}{c}\text { Relação de } \\
\text { Relevo }\end{array}$ & $\begin{array}{c}\text { Extensão do } \\
\text { percurso } \\
\text { superficial }\end{array}$ & $\begin{array}{l}\text { Coeficiente de } \\
\text { Manutenção }\end{array}$ & $\begin{array}{c}\text { Índice de } \\
\text { Rugosidade }\end{array}$ & $\begin{array}{c}\text { Textura } \\
\text { Topográfica }\end{array}$ \\
\hline BH 4_1 & 1,35 & 0,55 & 2,21 & 1,72 & 0,04 & 226,57 & 453,14 & 0,83 & 4,01 \\
\hline BH 4_2 & 1,37 & 0,53 & 2,15 & 2,13 & 0,05 & 232,06 & 464,11 & 0,70 & 3,90 \\
\hline BH 4_3 & 1,36 & 0,54 & 2,12 & 1,78 & 0,07 & 236,28 & 472,56 & 0,77 & 3,83 \\
\hline BH 4_4 & 1,67 & 0,36 & 2,12 & 2,68 & 0,06 & 235,64 & 471,28 & 0,89 & 3,84 \\
\hline BH 4_5 & 1,48 & 0,45 & 2,20 & 2,04 & 0,06 & 227,24 & 454,48 & 1,54 & 3,99 \\
\hline BH 4_6 & 1,24 & 0,65 & 2,45 & 2,19 & 0,11 & 204,05 & 408,11 & 1,57 & 4,50 \\
\hline BH 4_7 & 1,38 & 0,52 & 2,74 & 2,94 & 0,07 & 182,28 & 364,56 & 1,36 & 5,11 \\
\hline BH 4_8 & 1,38 & 0,53 & 2,11 & 1,67 & 0,06 & 237,42 & 474,84 & 1,07 & 3,80 \\
\hline BH 4_9 & 1,44 & 0,48 & 3,18 & 3,53 & 0,08 & 157,26 & 314,51 & 1,39 & 6,02 \\
\hline BH 4_10 & 1,41 & 0,50 & 2,40 & 2,36 & 0,05 & 208,07 & 416,14 & 1,45 & 4,41 \\
\hline BH 4_11 & 1,41 & 0,50 & 2,33 & 2,40 & 0,09 & 214,40 & 428,80 & 1,41 & 4,26 \\
\hline BH 4_12 & 1,40 & 0,51 & 2,38 & 2,73 & 0,06 & 210,38 & 420,75 & 1,14 & 4,35 \\
\hline BH 4_13 & 1,50 & 0,44 & 3,24 & 4,18 & 0,06 & 154,47 & 308,95 & 1,57 & 6,14 \\
\hline BH 4_14 & 1,37 & 0,53 & 2,27 & 2,22 & 0,07 & 220,66 & 441,32 & 1,26 & 4,13 \\
\hline BH 4_15 & 1,34 & 0,56 & 2,54 & 2,42 & 0,09 & 197,02 & 394,03 & 1,36 & 4,68 \\
\hline BH 4_16 & 1,29 & 0,60 & 2,47 & 2,42 & 0,07 & 202,52 & 405,04 & 1,30 & 4,54 \\
\hline BH 4_17 & 1,18 & 0,71 & 1,84 & 1,64 & 0,11 & 272,04 & 544,07 & 0,79 & 3,27 \\
\hline BH 4_18 & 1,42 & 0,50 & 2,29 & 2,15 & 0,05 & 218,00 & 436,00 & 0,71 & 4,18 \\
\hline BH 4_19 & 1,28 & 0,61 & 1,89 & 1,65 & 0,06 & 264,99 & 529,98 & 1,22 & 3,37 \\
\hline BH 4_20 & 1,41 & 0,50 & 1,94 & 1,24 & 0,04 & 258,17 & 516,35 & 1,35 & 3,47 \\
\hline BH 4_21 & 1,90 & 0,28 & 1,69 & 1,10 & 0,04 & 295,83 & 591,66 & 1,23 & 2,98 \\
\hline BH 4_22 & 1,46 & 0,47 & 2,22 & 1,84 & 0,02 & 225,40 & 450,80 & 1,60 & 4,03 \\
\hline BH 4_23 & 1,25 & 0,64 & 1,59 & 1,46 & 0,03 & 314,33 & 628,65 & 0,39 & 2,78 \\
\hline BH 4_24 & 1,67 & 0,36 & 1,38 & 1,60 & 0,03 & 361,96 & 723,93 & 0,23 & 2,38 \\
\hline BH 4_25 & 1,28 & 0,61 & 1,79 & 1,49 & 0,05 & 279,38 & 558,76 & 1,17 & 3,17 \\
\hline BH 4_26 & 1,23 & 0,66 & 1,60 & 1,01 & 0,07 & 312,87 & 625,75 & 0,91 & 2,80 \\
\hline
\end{tabular}



APÊNDICE H - Percentual de área dos atributos do meio físico das bacias hidrográficas de $4^{\mathrm{a}}$ ordem

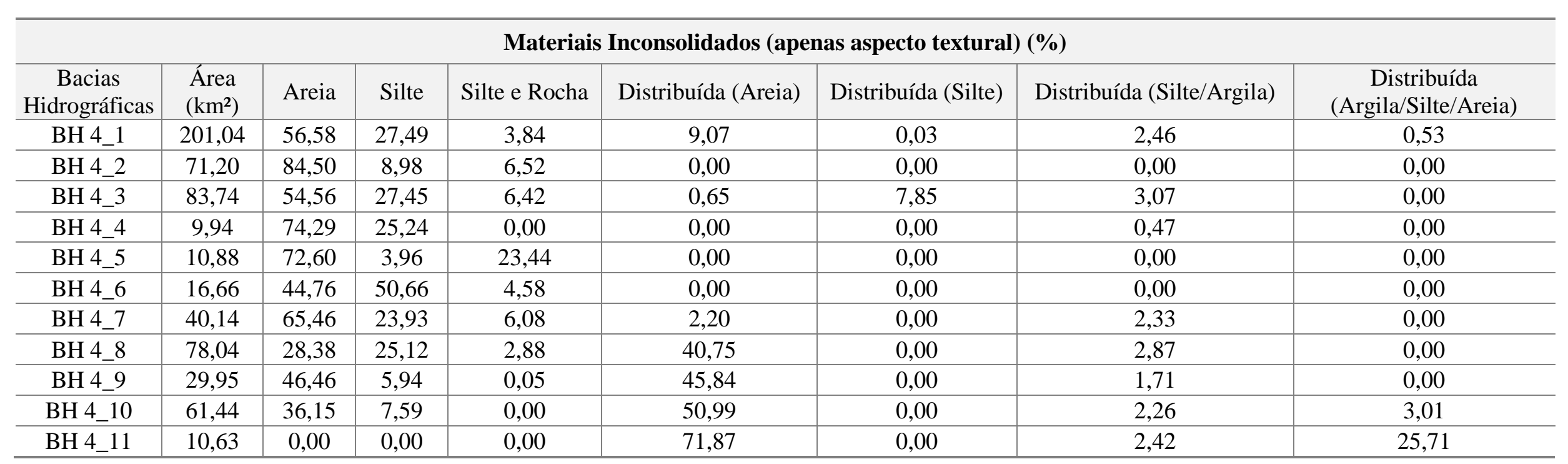




\begin{tabular}{|c|c|c|c|c|c|c|c|}
\hline \multicolumn{8}{|c|}{ Substrato Rochoso (\%) } \\
\hline $\begin{array}{c}\text { Bacias } \\
\text { Hidrográficas }\end{array}$ & Área $\left(\mathrm{km}^{2}\right)$ & Coberturas Quaternárias & Gnaisse & Xisto & Quartzito & Milonito & Xisto/Quartzito \\
\hline BH 4_1 & 201,04 & 0,74 & 9,26 & 16,99 & 55,39 & 5,02 & 12,60 \\
\hline BH 4_2 & 71,20 & 0,00 & 0,00 & 4,36 & 84,61 & 7,36 & 3,67 \\
\hline BH 4_3 & 83,74 & 0,07 & 10,93 & 15,55 & 53,10 & 20,35 & 0,00 \\
\hline BH 4_4 & 9,94 & 0,00 & 0,00 & 13,11 & 74,29 & 12,60 & 0,00 \\
\hline BH 4_5 & 10,88 & 0,00 & 0,00 & 0,65 & 71,88 & 3,96 & 23,51 \\
\hline BH 4_6 & 16,66 & 0,00 & 0,00 & 35,26 & 44,76 & 15,40 & 4,58 \\
\hline BH 4_7 & 40,14 & 0,00 & 2,17 & 18,47 & 59,34 & 0,00 & 20,02 \\
\hline BH 4_8 & 78,04 & 0,00 & 40,89 & 0,00 & 28,38 & 0,00 & 30,73 \\
\hline BH 4_9 & 29,95 & 1,46 & 31,88 & 0,00 & 46,46 & 0,00 & 20,20 \\
\hline BH 4_10 & 61,44 & 0,00 & 28,61 & 0,00 & 21,99 & 0,00 & 49,40 \\
\hline BH 4_11 & 10,63 & 0,00 & 52,68 & 0,00 & 0,00 & 0,00 & 47,32 \\
\hline
\end{tabular}




\begin{tabular}{c|c|c|c|c|c|c|c|c|c}
\hline \multicolumn{10}{c}{ Declividade (\%) } \\
\hline $\begin{array}{c}\text { Bacias } \\
\text { Hidrográficas }\end{array}$ & $\begin{array}{c}\text { Área } \\
\left(\mathrm{km}^{2}\right)\end{array}$ & $0-2 \%$ & $2-5 \%$ & $5-10 \%$ & $10-15 \%$ & $15-20 \%$ & $20-30 \%$ & $30-45 \%$ & $>45 \%$ \\
\hline BH 4_1 & 201,04 & 2,81 & 11,26 & 19,75 & 13,38 & 10,55 & 15,92 & 15,20 \\
\hline BH 4_2 & 71,20 & 2,66 & 8,61 & 17,30 & 14,07 & 11,38 & 17,77 & 16,38 & 11,83 \\
\hline BH 4_3 & 83,74 & 2,47 & 8,25 & 16,31 & 13,27 & 10,67 & 17,58 & 17,68 & 13,77 \\
\hline BH 4_4 & 9,94 & 2,82 & 10,33 & 12,30 & 6,43 & 6,28 & 12,69 & 20,52 & 28,63 \\
\hline BH 4_5 & 10,88 & 0,57 & 4,02 & 7,55 & 9,29 & 12,23 & 25,59 & 24,97 & 15,78 \\
\hline BH 4_6 & 16,66 & 0,97 & 4,43 & 10,10 & 10,21 & 9,71 & 18,37 & 23,44 & 22,77 \\
\hline BH4_7 & 40,14 & 2,32 & 9,24 & 20,09 & 17,65 & 12,87 & 17,44 & 14,13 & 6,26 \\
\hline BH4_8 & 78,04 & 6,15 & 17,12 & 25,20 & 15,15 & 9,70 & 12,21 & 9,23 & 5,24 \\
\hline BH4_9 & 29,95 & 6,03 & 21,92 & 28,81 & 15,01 & 9,90 & 10,98 & 5,63 & 1,72 \\
\hline BH 4_10 & 61,44 & 5,09 & 20,14 & 30,30 & 15,16 & 8,29 & 9,90 & 7,24 & 3,88 \\
\hline BH 4_11 & 10,63 & 35,90 & 16,12 & 21,56 & 14,72 & 6,25 & 3,31 & 1,84 & 0,30 \\
\hline
\end{tabular}

